UNIVERSIDADE DE SÃO PAULO

FACULDADE DE FILOSOFIA, CIÊNCIAS E LETRAS DE RIBEIRÃO PRETO DEPARTAMENTO DE EDUCAÇÃO, INFORMAÇÃO E COMUNICAÇÃO PROGRAMA DE PÓS-GRADUAÇÃO EM EDUCAÇÃO

\title{
A CONSTRUÇÃO DA IMAGEM DOS PARQUES INFANTIS DE RIBEIRÃO PRETO DAS DÉCADAS DE 1950 E 1960
}

Maria Beatriz Ribeiro Prandi 


\section{A CONSTRUÇÃO DA IMAGEM DOS PARQUES INFANTIS DE RIBEIRÃO PRETO DAS DÉCADAS DE 1950 E 1960.}

Dissertação apresentada ao Programa de PósGraduação em Educação do Departamento de Educação, Informação e Comunicação da Faculdade de Filosofia, Ciências e Letras de Ribeirão Preto da Universidade de São Paulo, como parte das exigências para obtenção do título de Mestra em Ciências (versão corrigida).

Orientador: Prof. Dr. Sérgio César da Fonseca 
Autorizo a reprodução e divulgação total ou parcial deste trabalho, por qualquer meio convencional ou eletrônico, para fins de estudo e pesquisa, desde que citada a fonte.

Prandi, Maria Beatriz Ribeiro

A construção da imagem dos parques infantis de Ribeirão Preto das décadas de 1950 e 1960. / Maria Beatriz Ribeiro Prandi; Orientador: Sérgio César da Fonseca. - Ribeirão Preto, 2015.

168 p. : il.

Dissertação (Mestrado) - Universidade de São Paulo, 2015.

1.Parques Infantis. 2.Ribeirão Preto. 3. História da Educação. 
À minha família. 


\section{AGRADECIMENTOS}

Agradeço primeiramente a Deus por iluminar e me guiar em todos os momentos, por me dar a oportunidade de realizar meus sonhos e por me proteger sempre.

Ao meu orientador, Prof. Dr. Sérgio César da Fonseca, pois, desde a disciplina ministrada por ele, que fiz como optativa na graduação, este tem me proporcionado aprendizados riquíssimos, além de sua calma e paciência terem sido fundamentais para me ajudar no desenvolvimento da pesquisa. Obrigada por depositar toda sua confiança em mim e no meu trabalho.

Agradeço aos meus pais por todo apoio, investimento, carinho, amor e paciência comigo. Se não fosse pela retaguarda de vocês, com certeza não teria chegado até aqui. Em especial agradeço a minha mãe por ter feito o slideshow dos parques infantis, que agora está disponível online; ao meu tio Agostinho Ribeiro da Silva, que fez a locução do slideshow e ao meu primo Glauco França que me ajudou a entender a arquitetura dos parques infantis. Agradeço também ao meu namorado Francisco Gonçalves, que me incentivou e não me deixou desistir nos momentos de fraqueza. Amo vocês!

À minha parceira de pesquisa e amiga Débora Menengotti Ferreira que, desde o desenvolvimento do projeto de pesquisa esteve do meu lado, ajudando-me não só com xerox, $p d f s$ e livros, mas também com todo seu conhecimento da área e sugestões que foram importantíssimas para conseguir terminar o trabalho. Agradeço também à historiadora Tânia Cristina Registro que, além de me fornecer vasta bibliografia sobre a história de Ribeirão Preto, estimulou-me na pesquisa e me faz querer sempre ser uma pesquisadora melhor.

Agradeço ainda à Prof. Dr. Simone Cecilio Hallak Regalo, que, apesar de atuar em outra área do conhecimento, deu-me total apoio, principalmente ao ler este trabalho e enriquecê-lo com dicas de uma profissional com vasta experiência no meio acadêmico.

Às minhas grandes amigas Nayara Cristini Bessi, que nos meus momentos de fraqueza não me fez cair no desespero e me ajudou a levantar e continuar no rumo certo da pesquisa; e Maria Gabriela Farias Cobianchi, que, com seus conhecimentos em descrição de imagens, guiou-me na elaboração do "Catálogo das fotografias avulsas com descritores icônicos e formais". Agradeço também ao amigo Nelson Oliveira Stefanelli por traduzir o resumo deste trabalho para o inglês.

Agradeço aos graduandos de Pedagogia (USP-RP) Valdson Almeira, Patricia Winchester, Kelly Cristina Reis e Thais Elias que, durante um ano, como bolsistas do Programa Aprender com Cultura e Extensão, deram-me apoio na busca por informações referentes aos parques infantis no Arquivo Público e Municipal de Ribeirão Preto e no Centro de Documentação dos Museus Histórico e do Café de Ribeirão Preto. Aproveito para agradecer às duas instituições por me permitirem pesquisar e me ajudarem durante esses dois anos de trabalho, e também à CAPES, pelo fomento à essa pesquisa.

Enfim, agradeço a todos que direta ou indiretamente contribuíram para o rumo da minha carreira e para o desenvolver desta pesquisa. 
“As fotografias são mundos de relações silenciosas, densas, congeladas no tempo mínimo do obturador. Mundos de seres calados e imóveis que devem ser decifrados a partir do contexto onde se encontram, na história de sua relação com os demais seres, tanto pessoas quanto objetos". (CIAVATTA; ALVES, 2004, p. 45). 


\section{RESUMO}

A presente dissertação é resultado do estudo acerca da produção da imagem pública dos parques infantis ribeirão-pretanos durante as décadas de 1950 e 1960, tendo como fonte de pesquisa a memória oficial para, deste modo, compreender e (re)construir o passado dos parques da cidade. Os parques infantis começaram a ser implantados em Ribeirão Preto em 1951 sob o discurso modernizante das autoridades políticas locais quanto a proporcionar, às crianças da cidade, recreação, atenção à saúde com atendimento médico e odontológico, cuidados higiênicos e, sobretudo, educação física. Esses locais permaneceram ativos até 1980, quando passaram de parques infantis a Escolas Básicas de $1^{\circ}$ Grau. Com isso, os parques tiveram de se adaptar para escolas com classes de recreação infantil, pré-alfabetização e classes de $1^{\circ}$ grau, e todo trabalho diferenciado e exaltado que era oferecido naqueles locais, principalmente as atividades lúdicas e a recreação, diminuiu ou deixou de existir. A partir das fontes históricas obtidas no Arquivo Público e Histórico de Ribeirão Preto (fotografias, álbuns, matérias de jornal, relatórios e almanaques), pode-se notar o quanto a imagem pública construída pelas diferentes administrações de Ribeirão Preto impregnou e contribuiu para a construção de uma memória dos parques infantis da cidade.

Palavras-chave: Parques Infantis. Ribeirão Preto. História da Educação. Memória. 


\begin{abstract}
This dissertation is the result of research on the public image production of Playgrounds in Ribeirão Preto during the 1950s and 1960s. As research source, the official memory was used to understand and (re) build the past of the Playgrounds in the city. Playgrounds began to be deployed in Ribeirão Preto in 1951 under the modernizing discourse of the local political authorities as to provide, to children of the city, recreation, health care (medical and dental), hygienic care and, above all, physical education. These places remained active until 1980, when they changed from Playgrounds to Elementary Schools. With this, the parks had to adapt to schools with children's recreation classes, pre-literacy and 1st grade classes, and all differentiated and exalted work which was offered in those places. Specially the recreational activities decreased or no longer existed. As of historical sources obtained within the Public and Historical Archives from Ribeirão Preto (photos, albums, newspaper articles, reports and almanacs), one can notice how the public image built by the different administrations of Ribeirão Preto impregnated and helped to build a memory of the Playgrounds in the city.
\end{abstract}

Keywords: Playgrounds. Ribeirão Preto. History of Education. Memory. 


\section{LISTA DE ILUSTRAÇÕES}

Figura 1 - Educação física no Parque Infantil Amélia Junqueira, setembro de 1961. Foto:

Miyasaka......

Figura 2 - Detalhe da figura 1

Figura 3 - Ambulatório médico do Parque Infantil Peixe Abbade, setembro de 1961. Foto:

Miyasaka.....

Figura 4 - Página do Álbum Histórico e Fotográfico dos Postos Odontológicos do Serviço

Dentário Municipal - Escoveiros.

Figura 5 - Crianças do Parque Infantil Peixe Abbade no momento da escovação

Figura 6 - Página do Álbum Histórico e Fotográfico dos Postos Odontológicos do Serviço

Dentário Municipal - assistência realizada no Parque Infantil Bandeirantes 42

Figura 7 - Página do Álbum Histórico e Fotográfico dos Postos Odontológicos do Serviço

Dentário Municipal - assistência realizada no Parque Infantil Santa Maria Goretti

Figura 8 - Página do Álbum Histórico e Fotográfico dos Postos Odontológicos do Serviço

Dentário Municipal - assistência realizada no Parque Infantil Anita Procópio Junqueira ....... 44

Figura 9 - Página do Álbum Histórico e Fotográfico dos Postos Odontológicos do Serviço

Dentário Municipal - assistência realizada no Parque Infantil Amélia Junqueira. .45

Figura 10 - Página do Álbum Histórico e Fotográfico dos Postos Odontológicos do Serviço

Dentário Municipal - assistência realizada no Parque Infantil Peixe Abbade .46

Figura 11 - Transporte oferecido às crianças dos parques até 1958

Figura 12 - Hora da alimentação no Parque Infantil Amélia Junqueira, setembro de 1961.

Foto: Miyasaka ..... 49

Figura 13 - Apresentação das crianças do Parque Infantil Dona Iria Junqueira na ocasião da inauguração do parque em 1959.

Figura 14 - Mapa dos subsetores de Ribeirão Preto .57

Figura 15 - Região administrativa de Ribeirão Preto .59

Figura 16 - Álbum 2 - Parque Infantil da Praça Antônio Prado em 10 de maio de 1953 .........64

Figura 17 - Álbum 3 - Parque Infantil da Praça Antônio Prado ................................................65

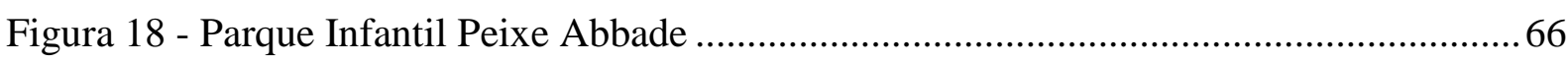

Figura 19 - Parque Infantil Peixe Abbade, setembro de 1961. Foto: Miyasaka.......................66

Figura 20 - Parque Infantil Peixe Abbade, setembro de 1961. Foto: Miyasaka.......................67

Figura 21 - Parque Infantil Peixe Abbade, setembro de 1961. Foto: Miyasaka.......................67

Figura 22 - Parque Infantil Peixe Abbade, setembro de 1961. Foto: Miyasaka........................68 
Figura 23 - Parque Infantil Amélia Junqueira 72

Figura 24 - Parque Infantil Amélia Junqueira, setembro de 1961. Foto: Miyasaka................. 72

Figura 25 - Parque Infantil Amélia Junqueira, setembro de 1961. Foto: Miyasaka.................73

Figura 26 - Parque Infantil Amélia Junqueira, setembro de 1961. Foto: Miyasaka.................73

Figura 27 - Álbum 1 - Lançamento da pedra fundamental do Parque Infantil da Vila Tibério75

Figura 28 - Álbum 1 - Inauguração da piscina do Parque Infantil da Vila Tibério................... 76

Figura 29 - Transporte e alimentação no Parque Infantil da Vila Tibério.................................78

Figura 30 - Parque Infantil Anita Procópio Junqueira, setembro de 1961. Foto: Miyasaka .... 79

Figura 31 - Parque Infantil Anita Procópio Junqueira......................................................... 80

Figura 32 - Piscina do Parque Infantil Anita Procópio Junqueira, setembro de 1961. Foto:

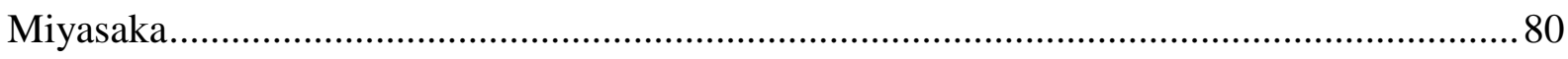

Figura 33 - Álbum 2 - Inauguração do Parque Infantil de Bonfim Paulista............................. 83

Figura 34 - Parque Infantil Dona. Iria Junqueira, setembro de 1961. Foto: Miyasaka ............ 84

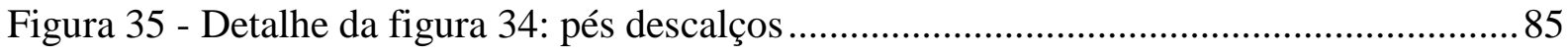

Figura 36 - Parque Infantil Dona Iria Junqueira, setembro de 1961. Foto: Miyasaka ............. 85

Figura 37 - Parque Infantil Dona Iria Junqueira, setembro de 1961. Foto: Miyasaka ............. 86

Figura 38 - Parque Infantil de Dumont, setembro de 1961. Foto: Miyasaka ............................ 88

Figura 39 - Parque Infantil de Dumont, setembro de 1961. Foto: Miyasaka ........................... 88

Figura 40 - Parque Infantil de Dumont, setembro de 1961. Foto: Miyasaka ........................... 89

Figura 41 - Parque Infantil de Dumont, setembro de 1961. Foto: Miyasaka ........................... 89

Figura 42 - Parque Infantil de Dumont, setembro de 1961. Foto: Miyasaka ........................... 90

Figura 43 - Álbum 2 - Parque Infantil da Vila Virgínia cedido ao Grupo Escolar .................. 93

Figura 44 - Álbum 2 - Parque Infantil da Vila Virgínia cedido ao Grupo Escolar .................. 94

Figura 45 - Álbum 3 - Parque Infantil da Vila Virgínia cedido ao Grupo Escolar .................. 95

Figura 46 - Parque Infantil Santa Maria Goretti, setembro de 1961. Foto: Miyasaka .............97

Figura 47 - Parque Infantil Santa Maria Goretti, setembro de 1961. Foto: Miyasaka ............. 97

Figura 48 - Parque Infantil Santa Maria Goretti, setembro de 1961. Foto: Miyasaka ............. 98

Figura 49 - Parque Infantil Santa Maria Goretti - piscina ................................................... 99

Figura 50 - Inauguração - Parque Infantil dos Bandeirantes, maio de 1963. Foto: Miyasaka102

Figura 51 - Inauguração - Parque Infantil dos Bandeirantes, maio de 1963. Foto: Miyasaka102

Figura 52 - Inauguração - Parque Infantil dos Bandeirantes, maio de 1963. Foto: Miyasaka103

Figura 53 - Inauguração - Parque Infantil dos Bandeirantes, maio de 1963. Foto: Miyasaka104

Figura 54 - Parque Infantil dos Bandeirantes, maio de 1963. Foto: Miyasaka ...................... 105 


\section{LISTA DE GRÁFICOS}

Gráfico 1 - Número de leis, decretos e resoluções por ano sobre os parques infantis de

Ribeirão Preto 119

Gráfico 2 - Leis, decretos e resoluções municipais sobre parques infantis da cidade 120

Gráfico 3 - Administradores municipais x número de leis, decretos e resoluções municipais

Gráfico 4 - Recorrência temática (álbuns e almanaques) 125

Gráfico 5 - Recorrência temática (fotografias avulsas) 126

Gráfico 6 - Número de fotografias (avulsas) por fotógrafo/estúdio 128

\section{LISTA DE QUADROS}

Quadro 1 - Inauguração dos parques infantis de Ribeirão Preto 56

Quadro 2 - Localização dos parques infantis de Ribeirão Preto. 58

Quadro 3 - Diferenças entre as datas de inauguração e leis de criação dos parques infantis de Ribeirão Preto 


\section{SUMÁRIO}

1. INTRODUCÃO 14

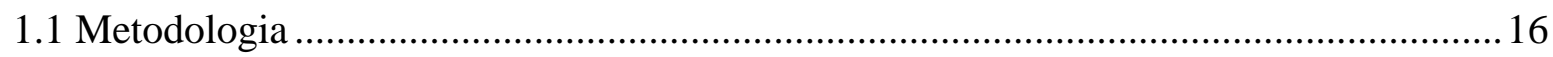

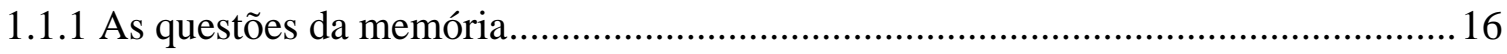

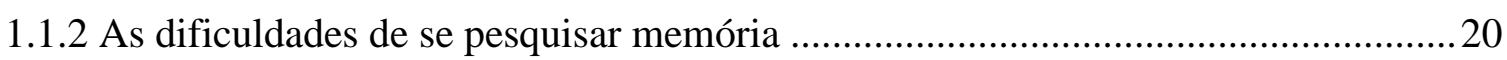

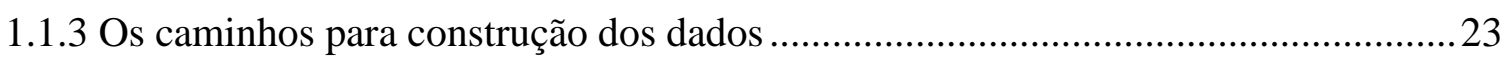

2. OS PARQUES INFANTIS DE RIBEIRÃO PRETO .............................................29

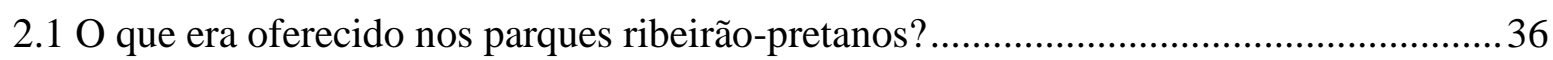

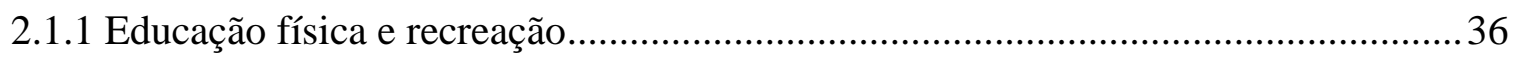

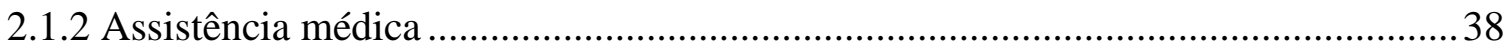

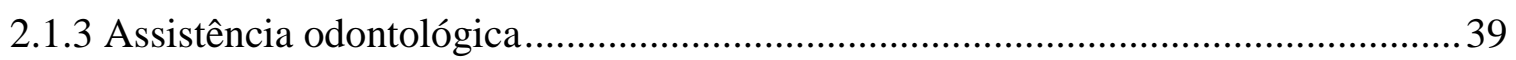

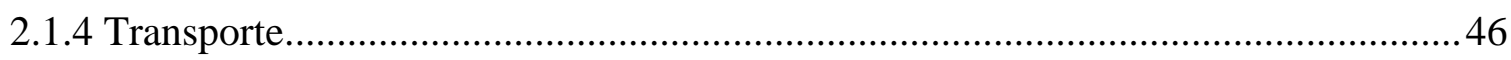

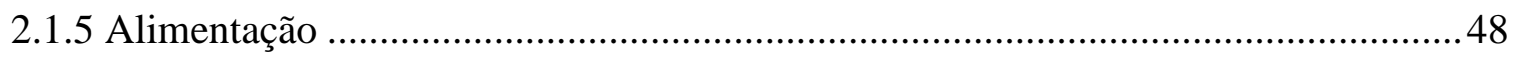

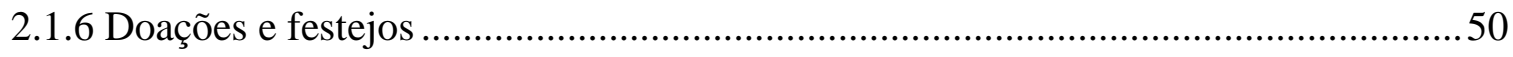

2.1.7 Olimpíadas parqueanas e campeonatos de futebol..................................................54

2.2 Distribuição territorial dos parques infantis de Ribeirão Preto........................................55

2.3 Os parques infantis de Ribeirão Preto de 1951 a 1963 .................................................60

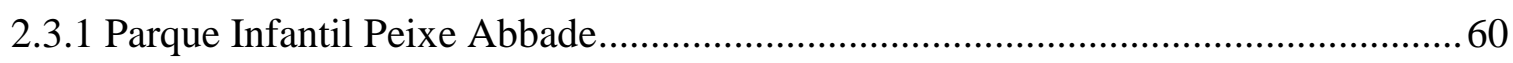

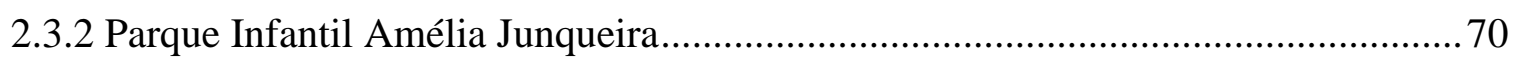

2.3.3 Parque Infantil Anita Procópio Junqueira ............................................................. 74

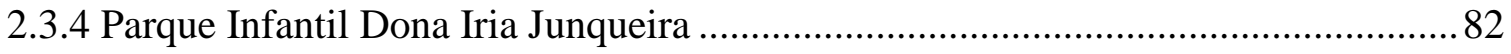

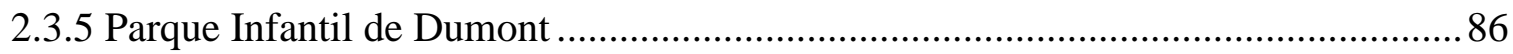

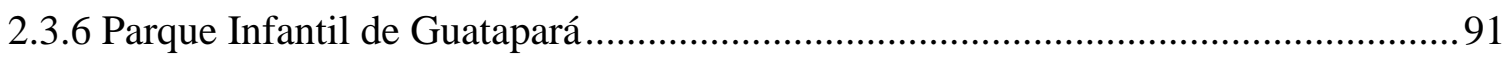

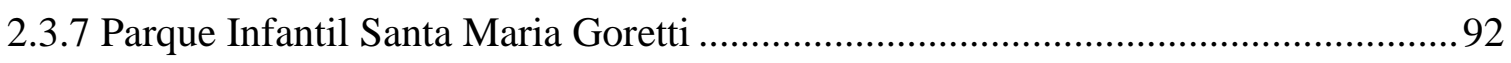

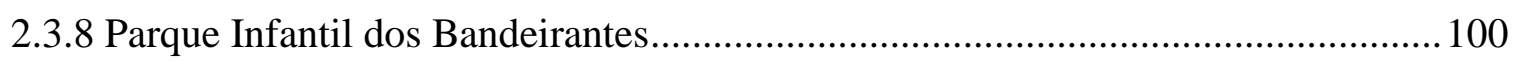

2.4 Os parques infantis de Ribeirão Preto pós-1963 …......................................................... 107

2.4.1 Parque Infantil Ana dos Santos Gabarra …............................................................ 107

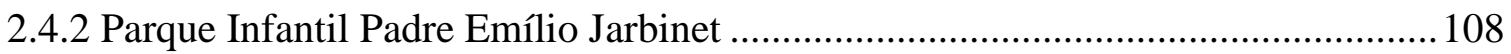

2.4.3 Parque Infantil Professora Áurea Apparecida Braghetto Machado ....................... 110

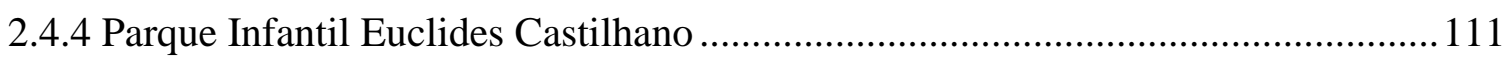

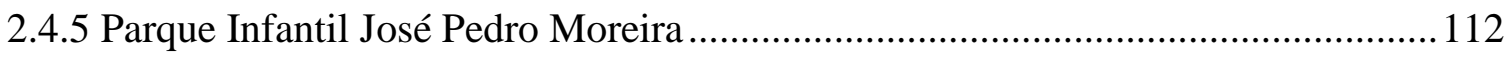

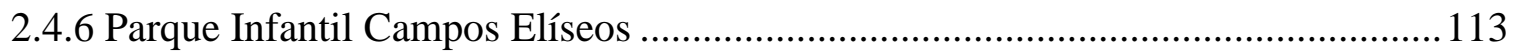




\section{SISTEMATIZANDO FONTES E DADOS PARA UMA DISCUSSÃO SOBRE A}

CONSTRUÇÃO DE IMAGENS PÚBLICAS ........................................................116

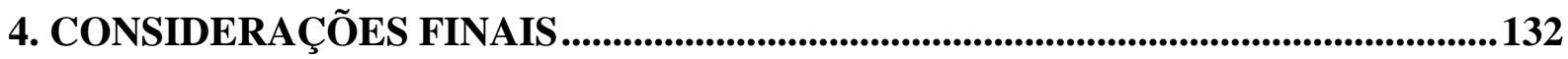

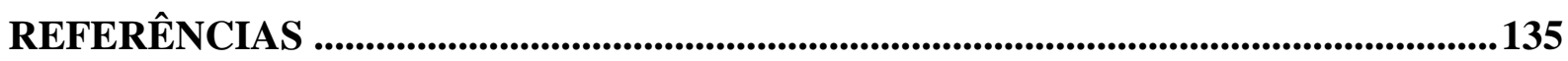

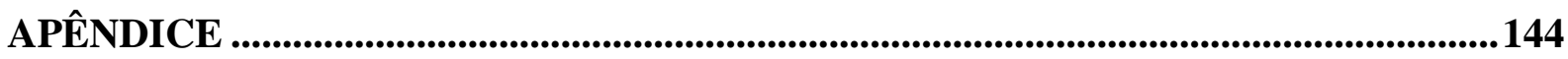

APÊNDICE A - Bibliografia sobre os parques infantil da cidade de São Paulo e do interior

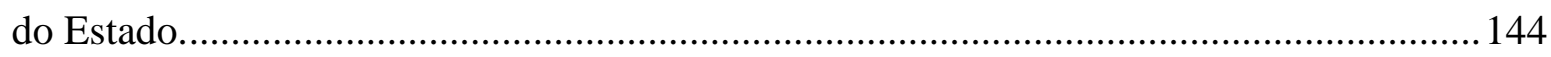

APÊNDICE B - Quadro com as encadernações dos jornais depositados no Arquivo Público e Histórico de Ribeirão Preto

APÊNDICE C - Quadro com o álbuns e almanaques depositados no Arquivo Público e Histórico de Ribeirão Preto que citam os parques infantis da cidade

APÊNDICE D - Quadro com as temáticas das fotografias dos álbuns e almanaques depositados no Arquivo Público e Histórico de Ribeirão Preto

APÊNDICE E - Quadro com as temáticas das fotografias avulsas sobre os parques infantis depositados no Arquivo Público e Histórico de Ribeirão Preto

ANEXOS

ANEXO A - Primeira página do termo de responsabilidade para acesso e uso de imagem para fins científicos, acadêmicos e culturais.

ANEXO B - Segunda página do termo de responsabilidade para acesso e uso de imagem para fins científicos, acadêmicos e culturais. 


\section{INTRODUCÃO}

A década de 1930 foi marcada pelo início do Estado Novo e, consequentemente, por uma nova configuração da política nacional: o coronelismo deu lugar à reorganização dos aparelhos do Estado, a estrutura social foi alterada pelo crescimento do setor industrial, a urbanização efervescente e o consecutivo advento dos trabalhadores rurais para a zona urbana. Esse novo cenário gerou uma outra preocupação política por parte dos governos estaduais e municipais: o atendimento à infância brasileira. (KRAMER, 1995).

Nesse contexto de desenvolvimento de novas políticas públicas surgiu um novo instrumento político, o Parque Infantil. A institucionalização do Parque Infantil ocorreu na década de 1930 em São Paulo, influenciado pelo escolanovismo ${ }^{1}$, como parte integrante de um grande projeto de reforma social da cidade. Todos eram construídos próximos às indústrias e a maioria das crianças eram filhos de operários, com faixa etária de 3 a 12 anos de idade. Nesses locais, em período integral ficavam as crianças com até 6 anos, e em meio período as crianças que já iam à escola de ensino regular. (MICARONI, 2007, p. 13).

O Parque Infantil, construído na cidade de São Paulo a partir de projeto de Mário de Andrade - escritor e então responsável pelo Departamento de Cultura do município, não era uma instituição responsável somente pela educação dos seus alunos, mas também pela sua recreação, alimentação e amparo médico e dentário. Segundo Moysés Kuhlmann Jr. (2011, p. 87), as ideias de Mario de Andrade sobre a criança e o parque infantil valorizavam uma nova referência para a nacionalidade e ao mesmo tempo enfatizavam o controle, a educação moral e a educação física.

De acordo com Kuhlmann Jr. (2000, p. 9), “o parque infantil, na década de 1940, expande-se para outras localidades do país como o interior do estado de São Paulo, o Distrito Federal, Amazonas, Bahia, Minas Gerais e Recife e Rio Grande do Sul”.

Na década de 1950 Ribeirão Preto já era uma cidade referência no interior do Estado de São Paulo e, para continuar desenvolvendo, buscou algumas alternativas, entre elas a incorporação no seu quadro educativo dos parques infantis que existiram em São Paulo ${ }^{2}$. Vale

\footnotetext{
${ }^{1}$ Movimento que contrapunha o que era considerado "tradicional”, ou seja, as ideias escolanovistas se diferenciavam das práticas pedagógicas até então empregadas.

${ }^{2}$ Há um documento no Arquivo Público e Histórico de Ribeirão Preto (Pasta 229 - caixa 43 - setor de protocolo dossiês - parque infantil), de 1952, sobre a $2^{a}$ Reunião de Diretoras de Parques Infantis. Pode-se notar que a reunião contou com a presença de representantes de todos os parques infantis do interior do Estado de São Paulo. Dessa maneira, temos que em 1952 havia 15 parques infantis no interior: Araraquara, Campinas, Franco da Rocha, Ibitinga, Itu, Jundiaí, Marilia, Mogi das Cruzes, Pinhal, Piracicaba, Pirajuí, Ribeirão Preto, Santos, São Vicente e Tremembé. Sete anos depois, de acordo com o projeto de Lei no 786/59 (BRASIL, 1959) publicado no
} 
lembrar que após a Segunda Guerra Mundial o desenvolvimento industrial acelerou-se e o "processo de urbanização intensificou-se, atraindo para os grandes centros urbanos uma parcela crescente da população brasileira. As cidades assumiram o papel central na economia e sociedade, congregando as mais variadas espécies de relações sociais". (GARAVAZZO; MARCONDES, 2004, p. 267).

Nesse período, com o processo de urbanização intensificado em Ribeirão Preto, a população urbana "elevou-se expressivamente e a cidade concentrou, cada vez mais, as compras e os serviços de toda a região da Alta Mogiana, particularmente dos seus arredores". (GARAVAZZO; MARCONDES, 2004, p. 267). Com esse aumento da população, o atendimento aos filhos da classe trabalhadora era essencial para o bom desenvolvimento da cidade e os parques infantis se transformaram num recurso privilegiado para essas famílias.

Logo após a inauguração do primeiro parque infantil em Ribeirão Preto (em 1951, por intermédio do Departamento de Educação Física do Estado de São Paulo), percebe-se, através de documentos depositados no Arquivo Público e Histórico de Ribeirão Preto, que o parque se diferia de tudo que havia na cidade (escolas públicas e particulares) e, com isso, era propagandeado na imprensa local como a pérola da educação da cidade, a qual deveria ser disseminada.

A perspectiva da mídia ou política pode moldar a imagem pública sobre um determinado objeto, fato, pessoa ou instituição. De acordo com Paula Guimarães Simões (2011), o processo de constituição de uma imagem pública pode ser investigado em um momento específico ou ao longo do tempo, entretanto ela está sempre em construção. Segundo a autora, tal processo "pode ser analisado em diferentes esferas da vida social, com objetivos e métodos diversos. Pode-se apreender a imagem de um indivíduo ou grupo nos campos da política, da economia ou do entretenimento". (SIMÕES, 2011, p. 129). Desse modo, a construção de uma imagem pública dos parques ribeirão-pretanos pode estar fundada sobre a ideia de que os acontecimentos que a imprensa local propagava não eram informações legítimas e simples do que ocorria na cidade, mas "resultados de um processo socialmente organizado, e socialmente regulado, de dar forma a, de encenar e de dar sentidos às informações, isto é, de descrições de ocorrências ou de situações”. (QUÉRÉ, 1997, p. 416 apud SIMÕES, 2011, p. 130, tradução da autora).

A presente pesquisa trata de analisar a produção da imagem pública dos parques infantis ribeirão-pretanos durante as décadas de 1950 e 1960, tendo como fonte de pesquisa a memória oficial para, deste modo, compreender e (re)construir o passado dos parques da cidade.

Diário Oficial de 7 de maio de 1959, havia 45 parques infantis no interior do Estado de São Paulo, sendo Campinas e Ribeirão Preto as duas cidades com mais parques infantis, cada uma com 6 parques. 
Este tema foi escolhido por sugestão do orientador após constatar que havia um conjunto considerável de fontes e um cenário na educação escolar da cidade no qual parecia que os parques infantis nunca existiram. A hipótese é que as administrações municipais utilizavam os meios de comunicação local, ou seja, a imprensa ribeirão-pretana, como ponte para projetar os parques e tornar público as atividades que ali eram realizadas, como uma espécie de boletim informativo. Essa grande divulgação na mídia aparece diversas vezes atrelada como uma forma de propaganda política.

Dessa maneira, a presente pesquisa questiona: os parques infantis de Ribeirão Preto eram realmente locais que empregavam o lazer em atividades saudáveis e de grande alcance moral e higiênico? Eram locais que promoviam o bem-estar da infância que se desenvolvia frequentemente em más condições higiênicas e morais? Locais que proporcionavam às crianças saírem de focos de maus hábitos, vícios e criminalidade para ambientes saudáveis e atraentes? (SILVA, C., 2008, p. 62). Ou isso era apenas o que os governantes, através da mídia, projetavam para a sociedade? Talvez a imagem disseminada pela mídia ao público não reproduzia a realidade da época e esta discrepância entre o discurso midiático e a realidade da época possivelmente causou seu esquecimento.

\subsection{Metodologia}

\subsubsection{As questões da memória}

Ao refletir sobre a imagem pública que foi construída naquele momento de novidade dos parques infantis de Ribeirão Preto (décadas de 50 e 60), logo pensamos em memória, como construção social, por sua vez unida à história. Apesar de intimamente relacionados estes conceitos não são sinônimos. Memória não é stricto senso história. A mitologia grega já indicava isso a sua maneira. Da união de Mnemosine, a deusa da memória, e Zeus, o deus supremo, nasceram nove musas cuja missão era proteger as artes. As nove filhas de Mnemosine e Zeus eram: Clio (história), Euterpe (poesia lírica), Talia (comédia), Melpômene (tragédia), Terpsícore (dança e canto), Érato (poesia erótica), Polínia (poesia sacra), Urânia (astronomia) e Calíope (poesia épica). (BULFINCH, 2006, p. 19). As musas possuíam criatividade e grande memória, tinham seus próprios templos, os Templos das Musas, e neles eram feitas reuniões culturais, nas quais as diversas modalidades das artes, como danças, poesias e narrações, eram ensinadas e preservadas. Sendo Clio a deusa da história, nota-se que a mitologia grega coloca a história como uma derivação da memória. 
Ainda na Antiguidade, a memória era bastante valorizada por ser uma ferramenta de grande valor para a retórica. Nesse período foi iniciado o desenvolvimento da Arte da Memória, como uma técnica para ativar a memória, algo semelhante ao que hoje denominamos mnemotecnia. Este conceito de Arte da Memória foi bastante explorado por muitos séculos. Giulio Camillo, no século XVI, ficou famoso por seu Teatro da Memória. Segundo Philipi Bloom (2003), tratava-se de um anfiteatro de sete níveis, em sete segmentos, cada um contendo um dos sete pilares da sabedoria:

A estrela desse teatro era a mente humana, ou, mais precisamente, a memória. A estrutura era nada mais, nada menos, do que um sistema mnemônico, [...] que lhe permitia visualizar tudo que existe na terra e colocá-lo em seu lugar apropriado na ordem simbólica do mundo, para ser resgatado no momento oportuno num debate ou longo discurso, o mais esmerado auxílio para a memória que já tinha sido construída. (BLOOM, 2003, p. 206).

Na tentativa de delimitar melhor o conceito de memória, seguem algumas definições: popularmente memória é tudo aquilo de que uma pessoa se lembra, como também sua capacidade de lembrar. Para Marilena Chaui (2005, p. 138) “a memória é uma evocação do passado. É a capacidade humana para reter e guardar o tempo que se foi, salvando-o da perda total”. Segundo Jacques Le Goff (1996, p. 477) “a memória, onde cresce a história, que por sua vez a alimenta, procura salvar o passado para servir o presente e o futuro. Devemos trabalhar de forma que a memória coletiva sirva para libertação e não para a servidão dos homens". Kalina Silva e Maciel Silva (2009) apontam que, de acordo com Le Goff, “a memória é a propriedade de conservar certas informações, propriedade que se refere a um conjunto de funções psíquicas que permite ao indivíduo atualizar impressões ou informações passadas, ou reinterpretadas como passadas". (SILVA; SILVA, 2009, p. 275).

De acordo com Giulia Crippa (2007, p. 122), a escrita é um meio de extensão da memória, que por sua vez é o "único instrumento através do qual podemos juntar ideias e palavras, ou seja, fugir ao império do imediato". Segundo a autora, a memória é o princípio de toda transmissão e fundamento cultural, pois sem ela "seria impossível realizar contratos, alianças ou convenções, impossível mantê-los, então não haveria elos sociais nem, enfim, sociedade, ou identidade individual e coletiva, nem mais conhecimento". (CRIPPA, 2007, p. 122).

Conclui-se então que memória é o que guardamos de nossas lembranças, e portanto, é um processo seletivo. Dentre tudo que vivenciamos, algo fica retido em nossa memória, e o restante é esquecido. Memória é, então, também, esquecimento; em outras palavras, por meio do esquecimento, se dá a memória. 
Se a memória costuma ser automaticamente correlacionada a mecanismos de retenção, depósito e armazenamento, é preciso apontá-la também como dependente de mecanismos de seleção e descarte. Ela pode, assim, ser vista como um sistema de esquecimento programado. Sem o esquecimento, a memória humana é impossível. (MENESES, 1992, 16).

Vale lembrar que não só indivíduos a produzem, mas também instituições e práticas sociais. Para Silva e Silva (2009, p. 276), o próprio esquecimento é um aspecto que deve ser levado em conta para a compreensão da memória de grupos, pois muitas vezes é uma vontade do próprio grupo que determinados fatos sejam ocultados. De tal modo, os fatos podem ser reelaborados constantemente por meio da memória coletiva.

A educação, através da escola, também tem esse papel de produtora de memória coletiva, podendo, inclusive, reter as informações que desejar.

\begin{abstract}
O indivíduo carrega em si a lembrança, mas está sempre interagindo com a sociedade, seus grupos e instituições. É no contexto destas relações que construímos as nossas lembranças. A rememoração individual se faz na tessitura das memórias dos diferentes grupos com que nos relacionamos. Ela está impregnada das memórias dos que nos cercam, de maneira que, ainda que não estejamos em presença destes, o nosso lembrar e as maneiras como percebemos e vemos o que nos cerca se constituem a partir desse emaranhado de experiências, que percebemos qual uma amálgama, uma unidade que parece ser só nossa. As lembranças se alimentam das diversas memórias oferecidas pelo grupo, a que o autor denomina 'comunidade afetiva'. E dificilmente nos lembramos fora deste quadro de referências. Tanto nos processos de produção da memória como na rememoração, o outro tem um papel fundamental.

Esta memória coletiva tem assim uma importante função de contribuir para o sentimento de pertinência a um grupo de passado comum, que compartilha memórias. Ela garante o sentimento de identidade do indivíduo calcado numa memória compartilhada não só no campo histórico, do real, mas sobretudo no campo simbólico. (KESSEL, s.d., p. 3).
\end{abstract}

Como conceituou Maurice Halbwachs (2006), a memória é um trabalho de reconhecimento (o que já foi visto) e reconstrução. A memória coletiva de uma instituição como a escola pode sim se perder, ser esquecida ou de fato apagada, pois dificilmente há quem reconstrua essas memórias. Segundo Ulpiano T. Bezerra de Meneses (1992, p. 14), “a memória é filha do presente. Mas como seu objetivo é a mudança, se lhe faltar o referencial do passado o presente permanece incompreensível e o futuro escapa a qualquer projeto".

Silva e Silva (2009, p. 276) apontam que "a forma de maior interesse para o historiador é a memória coletiva, composta pelas lembranças vividas pelo indivíduo ou que lhe foram repassadas, mas que não lhe pertencem somente, e são entendidas como propriedade de uma comunidade, um grupo". 
Tomando por referência que "o documento não é qualquer coisa que fica por conta do passado, é um produto da sociedade que o fabricou segundo as relações de força que aí detinham o poder" (LE GOFF, 1996, p. 545), pode-se dizer que o fato de não existir nenhuma referência nos históricos oficiais sobre os parques infantis de Ribeirão, bem como também nenhuma informação a respeito no website da Secretaria Municipal da Educação de Ribeirão Preto, aproxima-se mais da hipótese de que os anos de existência dos parques e o seu possível legado foram obliterados pelo poder público, seu original criador e mantenedor. Certamente a primeira pista para estudar esse processo foi o fato de os parques infantis, a partir de seu conjunto de funcionários, de seu patrimônio físico e de seus alunos, terem encorpado a rede municipal de escolas de Educação Infantil e de Ensino Fundamental a partir de 1980.

Nas atuais escolas municipais que foram outrora parques infantis - como tivemos oportunidade de constatar em visita a elas - quase não existem vestígios desse passado. Fisicamente não há nada que identifique esse tempo, a não ser o fato de as construções originais ainda permanecerem, porém não identificadas por qualquer sinal que as associe à origem parqueana. Quanto às pessoas, poucos são os que conhecem em profundidade o passado da escola onde atuam e que são capazes de se referirem aos tempos de parque infantil. Pudera, pois lá se vão mais de cinco décadas e vários dos que trabalharam no tempo dos parques na educação municipal não estão mais "na ativa" ${ }^{\text {" }}$ Por isso algumas perguntas são pertinentes. É fato que os parques infantis existiram, mas, afinal, o que restou deles? Há memória, há história ou os dois? Para responder tais questionamentos, primeiramente deve-se ter claro os conceitos de memória e história.

Enquanto memória, como já foi dito, é o que retemos de nossas lembranças, história é o registro dessa memória. De acordo com Silva e Silva (2009, p. 276), a memória recupera, no indivíduo ou em um grupo, o que está submerso e a história lida com o que a sociedade trouxe a público em um tempo determinado. Outra distinção que as autoras trazem é que a história trabalha com o "acontecimento colocado para e pela sociedade, enquanto para a memória o principal é a reação que o fato causa no indivíduo”. (SILVA; SILVA; 2009, p. 276).

\footnotetext{
${ }^{3}$ As professoras e funcionários entrevistados por Darahem (2011), por exemplo, ao tempo de realização desta pesquisa já estavam aposentados e fora das escolas onde atuaram, o que corrobora em parte para esta constatação. Não é diferente das entrevistadas por Ferreira (2010) que estiveram nos parques infantis durante a década de 1950. De certo modo, o afastamento das pessoas do lugar levou consigo quem pudesse representar essa memória in loco, pois à medida que aqueles que são capazes de rememorar esse passado parqueano se dispersam em relação à presença num lugar de memória, no caso as originais escolas que foram construídas para serem parques infantis, não havia mais quem portasse essa memória e o falar sobre ela aos colegas remanescentes.
} 
De acordo com Crippa (2007, p. 120), só foi possível fazer história a partir do surgimento da escrita, pois esta possibilitou o registro e disseminação memórias individuais e coletivas. Com a invenção de tecnologias como prensas de tipos móveis essa disseminação de memórias foi intensificada, pois tudo o que era considerado digno de ser transmitido ao próximo foi prensado em uma superfície com tinta, transferindo textos ou gravuras para uma superfície como papel ou tecido. Tal acontecimento pode ser considerado um dos marcos mais importantes até o século XIX, pois revolucionou a transmissão do conhecimento humano e possibilitou o que se procurava: extensões da memória.

Como foi no caso da escrita, as novas tecnologias modificam profundamente a relação existente entre os seres humanos e sua memória. Os Sistemas Artificiais de Memória (SAM), ou seja, todos os objetos materiais que permitem gravar, estocar, manipular, transmitir e ler a informação, libertaram o homem dos limites de sua memória biológica, e influenciam os mecanismos de tomada de decisão, enriquecendo qualitativamente a memória coletiva. De fato, graças aos SAM, podemos compartilhar lembranças que alguns jamais vivenciaram. (CRIPPA, 2007, p. 121).

A história propriamente dita vem, então, estudar, organizar e traduzir, para um receptor, informações que a memória reconhece, através de narrativas individuais ou coletivas. No caso da história dos parques infantis a documentação presente no Arquivo Público e Histórico de Ribeirão Preto certamente cabe no estatuto atribuído por Le Goff (1996, p. 547) ao documento como sendo o material da memória, pois equivalente a "uma montagem consciente ou inconsciente, da história, da época, das sociedades" que os produziram, mas que só chega a sair do esquecimento quando o historiador o lê, de sorte que neste trabalho a leitura e análise dessas fontes nos permite compreender a história algo obliterada dos parques infantis do município.

\subsubsection{As dificuldades de se pesquisar memória}

Visando compreender e (re)construir o passado dos parques infantis de Ribeirão Preto em razão do que representaram para a história da educação paulista e, consequentemente, o porquê do seu esquecimento, através de uma pesquisa que utiliza conceitos como memória, o primeiro passo foi realizar uma busca rigorosa por bibliografia cujos temas entrelaçassem de algum modo as questões ora discutidas, bem como informações acerca desses assuntos.

No senso comum a "memória" sempre esteve bastante atrelada ao sentido biológico, da capacidade que o indivíduo possui de recordar algo. Atualmente o termo é também bastante relacionado a dispositivos de armazenamento de dados. Fala-se então em memórias de computadores, pen-drives e de tocadores de música digitais. No campo científico tem-se a 
memória como processo neuroquímico, através de sinapses que possibilitam o armazenamento de informações. Ou, ainda na área tecnológica, a memória está ligada aos processos de desenvolvimento de dispositivos de armazenamento de dados, com capacidade cada vez maior, e tamanho opostamente menor.

Ao pesquisar o termo "memória" na lista de assuntos de artigos científicos da base de dados Scielo, a quantidade e variedade de termos indexados encontrados foi imensa, entre os quais constavam: memória, memória a curto prazo, memória coletiva, memória em flebotomíneos, memória histórica, memória traumática, memória oral, dentre outros. O exemplo da lista de assuntos nos mostra a polissemia que permeia o significante "memória". Esta pluralidade de significados constituiu um desafio para a revisão bibliográfica em torno do termo e, portanto, necessitou de uma análise rigorosa das referências que foram adquiridas.

Após a busca por referências sobre memória, foi realizada uma discussão em torno do tema e um enfoque em história e fotografia, debatendo a importância da imagem como documento de valor histórico, pois recorremos principalmente à história que as fotografias e álbuns depositados no Arquivo Público e Histórico de Ribeirão Preto ${ }^{4}$ contam sobre os parques infantis que existiram na cidade ${ }^{5}$.

No Arquivo citado, há documentos que destacam os parques infantis como "a menina dos olhos" da Educação em Ribeirão Preto, principalmente nas décadas de 1950 e 1960, pelo papel que desempenhavam entre o universo escolar e o assistencial, pois lidavam com crianças pobres, incutindo nelas hábitos higiênicos, contando sempre com o investimento na cultura dos cuidados bucais.

Em busca de outras informações oficiais, o arquivo da Câmara Municipal de Ribeirão Preto também nos serviu de fonte. É importante ressaltar que toda a documentação da Câmara está depositada no Arquivo Público e Histórico de Ribeirão Preto. Dessa maneira, o acervo local da Câmara acomoda apenas os livros com todas as Leis, Decretos e Resoluções Municipais de Ribeirão Preto, que podem ser analisados se o pesquisador já tiver de antemão o número da lei ou que deseja pesquisar. Além disso, todas as Leis, Decretos e Resoluções desde o final da década de 1940 estão disponíveis no website ${ }^{6}$ da Prefeitura Municipal de Ribeirão

\footnotetext{
${ }^{4}$ Para realização da pesquisa e uso de documentos do Arquivo, foi assinado um Termo de responsabilidade para acesso e uso de imagens para fins científicos, acadêmicos e culturais, que garante a liberação da reprodução das imagens obtidas no Arquivo (ANEXOS A e B).

${ }^{5}$ Houve também dificuldade em pesquisar o termo "parque infantil", pois tanto em todos os bancos de dados pesquisados, como quando perguntamos para alguém sobre "parques infantis", há sempre a relação de "parque infantil" como playground, e não como a instituição de modelo paraescolar.

${ }^{6}$ PREFEITURA MUNICIPAL DE RIBEIRÃO PRETO. Legislação Municipal. Disponível em: <http://www.ribeiraopreto.sp.gov.br/leis/pesquisa/j321 pesquisa.htm >. Acesso em: 20 out. 2013.
} 
Preto, ou seja, toda legislação municipal do período dessa pesquisa está disponível online, necessitando apenas da presença física no local do acervo quando alguma Lei, Decreto ou Resolução não for encontrada ou estiver incompleta no website.

O Centro de Documentação dos Museus Histórico e do Café de Ribeirão Preto também foi um local de busca por informações sobre os parques infantis. Foram encontrados recibos de doações para parques infantis de frutas, doces, carne de porco, banha de porco, café em pó; e ainda recibos feitos pelos museus sobre recebimento do almoxarifado, de açúcar para o preparo de doces para os parques infantis.

Além do Arquivo Público e Histórico de Ribeirão Preto, do Centro de Documentação dos Museus Histórico e do Café de Ribeirão Preto e da Câmara Municipal de Ribeirão Preto, o Museu da Imagem e do Som "José da Silva Bueno" (MIS-RP) e a Biblioteca Municipal "Guilherme de Almeida", integrantes do Complexo Cultural Alto do São Bento, também foram consultados.

O MIS-RP tem como finalidade "organizar, conservar, preservar e dar acesso à memória musical, fotográfica, sonora e audiovisual” (PREFEITURA, 2014, p. 2) da cidade. Todavia, apesar de ter mais de 36 anos de existência, a catalogação do acervo do museu ainda está em andamento (começou em 2011) e as pesquisas são realizadas somente por meio da memória da historiadora que está realizando a catalogação. Por conseguinte, não foi possível realizar uma pesquisa adequada no MIS-RP e nenhuma informação sobre os parques infantis da cidade foi encontrada no local.

Na Biblioteca Municipal "Guilherme de Almeida" não há informações referentes aos parques infantis de Ribeirão Preto. Entretanto, há uma ampla bibliografia sobre a História de Ribeirão Preto, a qual serviu de base para a compreensão da evolução e modernização da cidade. Vale lembrar que é uma biblioteca com excelentes títulos, porém com infraestrutura precária, não automatizada, sem espaço adequado para consultas e pesquisas e sem serviço de empréstimo adequado.

Outra instituição de memória consultada foi o Centro de Documentação Professora Glete de Alcântara, da Escola de Enfermagem de Ribeirão Preto (EERP-USP). Esse Centro tem uma documentação importante sobre a história da enfermagem de Ribeirão Preto dos anos 1951 a 1971, período de permanência dos parques infantis da cidade. Sem embargo, não foi encontrado nenhum documento referente ao trabalho que as enfermeiras da cidade realizavam nos parques infantis.

Com o andamento do trabalho surgiu a necessidade de conhecer e pesquisar o arquivo pessoal do fotógrafo Tony Miyasaka, com cujo acervo fotográfico obtivemos contato, porém o 
local não abriga todas as fotografias feitas durante carreira do fotógrafo, apenas as que ele desejou preservar. Nota-se, através de análise dos registros desse acervo, que Miyasaka procurou preservar, através de suas fotografias, a memória da cidade e as personalidades mais influentes do município. Entretanto, dos 603 registros encontrados, apenas dois se referem aos parques infantis de Ribeirão Preto:

- o Registro 169, que se refere ao Parque Infantil Vila Recreio, com dois negativos de $7 \times 6 \mathrm{~cm} ;$ e

- o Registro 184, referente ao Parque Infantil do Barracão e Praça Antônio Prado, com um negativo $12 \times 10 \mathrm{~cm}$.

Todavia, os dois registros encontrados são de negativos de fotografias depositadas no Arquivo Público e Histórico de Ribeirão Preto. Isso posto, o arquivo se tornou a única instituição da cidade com aptidão de apresentar a memória oficial dos parques infantis de Ribeirão Preto ${ }^{7}$.

\subsubsection{Os caminhos para construção dos dados}

A princípio, foi realizada uma busca por documentos no Arquivo Público e Histórico de Ribeirão Preto e por bibliografia sobre a História da Educação de Ribeirão Preto nas décadas de 1950 e 1960, que tivesse pelo menos uma citação sobre os parques infantis da época, em bibliotecas públicas, particulares e universitárias da cidade e também em websites.

Em relação à bibliografia, pouco foi encontrado sobre os parques infantis de Ribeirão Preto, apenas três pesquisas ${ }^{8}$ :

1. A dissertação de mestrado de Gabriela Campos Darahem (2011) ${ }^{9}$, intitulada Contribuição para a história da educação infantil em Ribeirão Preto: experiências de funcionários e professoras das Escolas Municipais de Educação infantil (EMEIs), a qual teve como objetivo estudar a história da educação infantil municipal de Ribeirão Preto e, por meio da história oral, registrou a

\footnotetext{
${ }^{7} \mathrm{O}$ contato com o acervo Miyasaka não trouxe novas informações iconográficas ao trabalho, contudo seu rico acervo bibliográfico sobre história da fotografia alavancaram o desenvolvimento do capítulo três.

${ }^{8}$ Contudo, há uma vasta bibliografia sobre os parques infantis da cidade São Paulo e de outras cidades do Estado que permitem compreender como eles surgiram e também a organização do modelo didático-pedagógico dos parques infantis de todo o Estado. (Apêndice A).

${ }^{9}$ DARAHEM, Gabriela Campos. Contribuição para a história da educação infantil em Ribeirão Preto: experiências de funcionários e professoras das Escolas Municipais de Educação infantil (EMEIs). 2011.

Dissertação (Mestrado em Psicologia)-Faculdade de Filosofia, Ciências e Letras de Ribeirão Preto, Universidade de São Paulo, Ribeirão Preto, 2011.
} 
contribuição das pessoas que protagonizaram a construção dessa história desde seu começo, incluindo participantes ativos dos parque infantis da cidade;

2. O relatório final da iniciação científica de Débora Menengotti Ferreira $(2010)^{10}$, intitulado Memórias do magistério: idealização do passado e exercício da profissão no presente, que teve como objetivo resgatar a memória do atendimento à criança pequena pelo município de Ribeirão Preto nas décadas de 1960 e 1970, bem como assuntos relacionados às instituições existentes no período, englobando os parques infantis; e

3. O relatório final da iniciação científica de Michele Cristina Fincoti (2012) ${ }^{11}$, também intitulado Memórias do magistério: idealização do passado e exercício da profissão no presente por ser a continuação da pesquisa de Débora Menengotti Ferreira, o qual analisou as atividades desenvolvidas nos parques infantis de Ribeirão Preto de 1951 a 1968.

A dissertação de Gabriela Campos Darahem (2011) e o relatório final da iniciação científica de Débora Menengotti Ferreira (2010) foram importantíssimos para o desenvolvimento deste trabalho, pois as duas autoras utilizaram como metodologia a história oral, entrevistando ex-professores e ex-funcionários dos parques infantis de Ribeirão Preto. Dessa forma, pudemos utilizar a transcrição dessas entrevistas ${ }^{12}$, alcançando então aspectos da memória que, diferentemente dos documentos para a história, concretizam-se em discurso falado sobre um processo histórico passado.

No Arquivo Público e Histórico de Ribeirão Preto, inicialmente, foram encontrados dois álbuns, um almanaque, uma caixa intitulada "Dossiê dos parques infantis", artigos de jornais e algumas fotos avulsas. De acordo com esses documentos e com a análise da bibliografa citada, acreditava-se, inicialmente, que apenas sete parques infantis haviam sido implantados em Ribeirão Preto. Entretanto, com o desenvolvimento da pesquisa no arquivo esse número foi ampliado para quatorze, sendo que há registros (leis de criação ou autorização para construção)

\footnotetext{
${ }^{10}$ FERREIRA, Débora Menengotti. Memórias do magistério: idealização do passado e exercício da profissão no presente. 2010. 62 f. Iniciação Científica (Programa Ensinar com Pesquisa)-Faculdade de Filosofia, Ciências e Letras de Ribeirão Preto, Universidade de São Paulo, 2010.

${ }^{11}$ FINCOTI, Michele Cristina. Memórias do magistério: idealização do passado e exercício da profissão no presente. 2012. 89 f. Iniciação Científica (Programa Ensinar com Pesquisa)-Faculdade de Filosofia, Ciências e Letras de Ribeirão Preto, Universidade de São Paulo, 2012.

${ }^{12}$ No decorrer de uma pesquisa que utiliza história oral como metodologia são gerados documentos, os quais também entram para a história escrita através das transcrições das entrevistas.
} 
de mais cinco parques - mas não sabemos se eles chegaram a existir ou não ${ }^{13}$ - assim como a descoberta de novas fontes sobre esses locais.

As caixas de arquivo com documentos sobre os parques agora totalizam 29, contendo diversos tipos de materiais, incluindo correspondências, plantas, ponto dos professores, pedido de materiais e notas de compras, lista de material didático, livros de chamadas, quadro de servidores, autorização para exames médicos, relatórios médicos, inventário de material, registro de pessoas interessadas em trabalhar nos parques, escala de férias dos professores, escala de substituição de professores, orçamentos, balancete mensal beneficente do caixa parqueano, entrevistas, ofícios expedidos, documentação para construção de parques, relatórios do Departamento de Cultura de Ribeirão Preto, quadro geral das despesas da municipalidade e leis municipais. Esses documentos nos informam como ocorreram os processos de implantação dos parques na cidade, bem como nos permitem conhecer o funcionamento e o dia a dia deles.

A busca por Leis, Decretos e Resoluções municipais sobre os parques infantis e a organização da informação encontrada foi imprescindível para o desenvolvimento desta pesquisa, pois é a única ferramenta que nos permite a certeza de qual administração criou cada parque na cidade e o benefício concedido a cada um deles ${ }^{14}$.

Em relação aos jornais, a princípio seriam consultados somente "A Cidade”, "A Tarde” e "Diário da Manhã", pois eram jornais com grande repercussão na cidade nas décadas de 1950 e 1960. Contudo, após a ampliação do número inicial de parques infantis, decidimos que todos os jornais em circulação no período deveriam ser pesquisados, ampliando assim os grupos que "falam" sobre os parques, e assim novas informações foram surgindo a partir da leitura de "O Diário", "Diário Oficial”, “Gazeta”, "Pasquim” e "Diário de Notícia”. (Apêndice A) ${ }^{15}$.

Os álbuns e almanaques pesquisados, os quais a princípio totalizavam três, mas que agora somam sete (Apêndice B), também tem profunda relevância, pois foram elaborados pelas

\footnotetext{
${ }^{13}$ A Lei no 890 (RIBEIRÃO PRETO, 1959c), de 03 de dezembro de 1959, cria o Parque Infantil de Vila Paulista; a Lei no 1475 (RIBEIRÃO PRETO, 1964c), de 10 de novembro de 1964, autoriza a construção de um Parque Infantil em Vila Abranches; A Lei no 1507 (RIBEIRÃO PRETO, 1964d), de 01 de dezembro de 1964, cria um Parque Infantil em Vila Seixas; a Lei no 3395 (RIBEIRÃO PRETO, 1977b), de 19 de dezembro de 1977, cria um Parque Infantil no bairro Jardim Independência; e a Lei no 3618 (RIBEIRÃO PRETO, 1979), de 17 de maio de 1979, dispõe sobre a criação de um parque infantil na Vila Albertina.

${ }^{14}$ No total foram encontradas 65 Leis, Decretos e Resoluções municipais sobre os parques infantis de Ribeirão Preto.

${ }^{15}$ Em Ribeirão Preto a imprensa dominava a cidade. De acordo com o IBGE (1958, p. 36), havia no município “[...] 4 jornais diários, matutinos: 'Diário da Manhã', 'A Cidade', 'Diário de Notícias' e 'O Diário'. O município conta, ainda, com duas emissoras: Rádio Clube de Ribeirão Preto - PRA-7, com frequência de 730 quilo ciclos e com o máximo de potência na antena 1000 I 500 W., e a Rádio Ribeirão Preto Ltda. - ZYR-79 e ZYR-92 (ondas curtas), com frequência de 780 quilo ciclos e com o máximo de potência na antena de $250 \mathrm{~W}$. Tem [em Ribeirão Preto] 15 bibliotecas com mais de 1500 volumes, sendo que a da Faculdade de Medicina possui 13000 volumes, havendo, ainda, uma biblioteca estudantil, com 14000 volumes. A sede municipal possui, ainda, 8 livrarias e 14 tipografias".
} 
administrações municipais da cidade e, com esses materiais, podemos perceber que os parques infantis eram considerados a joia rara da educação ribeirão-pretana. De acordo com Solange Ferraz de Lima e Vânia Carneiro de Carvalho (1997), os álbuns são um tipo de publicação iconográfica em que fotografias com um arranjo específico são unidas para representar determinado assunto ou ideia. De acordo com as autoras, "trata-se de um tipo de publicação no qual a imagem visual é predominante e assume um papel ativo na construção de sentidos, articulando-se, ao invés de submeter-se aos textos e legendas". (LIMA; CARVALHO, 1997, p. 19).

A memória dos parques infantis emanada desses álbuns pode ser encarada de maneiras diferentes, pois as fotografias ali contidas podem ser vistas como geminação do real ou como intencionais, uma vez que temos de considerar que são uma produção política e que pode ter havido intencionalidade na escolha das imagens neles inseridas, pois por meio da fotografia "o conhecimento histórico deixa de ser percebido como dado natural e passa a ser entendido como conteúdo cultural sujeito a interpretações”. (BORGES, 2011, p.17, grifo do autor).

As fotografias avulsas também se consagraram como rica fonte de pesquisa: foram encontradas 66 imagens oficiais, encomendadas pela Prefeitura Municipal a fim de nos apresentar o dia a dia dos parques da cidade. Vale realçar que a imagem fotográfica será entendida aqui como algo que ultrapassa seu plano, isto é,

vai além do que mostra em sua superfície. Naquilo que não tem explícito, o
tema registrado tem sua explicação, seu porquê, sua história. Seu mistério se
acha circunscrito, no espaço e no tempo, à própria imagem. Isto é próprio da
natureza da fotografia: ela nos mostra alguma coisa, porém seu significado a
ultrapassa. Existe um conhecimento implícito nas fontes não-verbais como a
fotografia; descobrir os enigmas que guardam em seu silêncio é desvendar
fatos que lhe são inerentes e que não se mostram, fatos de um passado
desaparecido, nebuloso que tentamos imaginar, re-criar, a partir de nossas
imagens mentais, em eterna tensão com a imagem presente que concretamente
vemos, limitada à superfície do documento: realidades superpostas. Toda
fotografia é o frontispício de um livro sem páginas, um elo que nos anuncia
algo e que, ao mesmo tempo, nos despista. Resta-nos mergulharmos nesses
fragmentos deslizantes de ambiguidade e evidência, para tentarmos desvendar
os mistérios que se escondem sob olhares interessantes e paisagens perdidas.
[...] Seguir decifrando essa forma de conhecimento é o desafio que nos move.
(KOSSOY, 2007, p. 60).

As 66 fotografias avulsas passaram pelos processos de análise iconográfica e análise iconológica. No primeiro tipo de análise foi realizada a descrição e a classificação da imagem. De acordo com Vânia Souza e Vânia Olária (2014, p. 9), essa primeira etapa "é uma fase carregada de objetividades, descrição dos seus detalhes e também de sua contextualização 
histórica". Para tanto, foi elaborado um catálogo das fotografias avulsas com descritores icônicos e formais ${ }^{16}$.

A partir da análise iconográfica pudemos realizar a análise iconológica, na qual os símbolos e sintomas culturais foram interpretados, evidenciando a personalidade de uma civilização, no caso a população ribeirão-pretana. Para Souza e Olária (2014, p. 9), "neste momento os elementos selecionados da obra são relacionados com a filosofia, cultura, religião da comunidade da época".

Dessa maneira, consideramos todas as imagens não apenas enquanto consolidações visuais de definições fixas, mas também ponderando a respeito de toda a rede de produção e circulação, tecendo uma trama de dados em torno dos álbuns, almanaques e fotografias avulsas encontradas, uma vez que estes documentos são frações, não são donos de uma verdade própria, pois cabem apenas em si. "A partir da operação particular de transformar vestígios em dados de pesquisa, o historiador/pesquisador produz um discurso, uma narrativa que constitui sua leitura do passado". (STEPHANOU; BASTOS, 2011, p. 417).

Vale lembrar que todos os documentos coletados no Arquivo sobre os parques infantis da cidade emanam intencionalidades que constroem uma memória da História da Educação de Ribeirão Preto. Os anos continuados da existência e atividade dos parques, pós 1980, parecem ter caído no esquecimento e toda benfeitoria que eles proporcionaram à população de Ribeirão Preto parece ter sido obliterada. Por conta disso, alguns instrumentos de pesquisa foram elaborados a fim de reconstruir esse passado e também de se tornarem fontes para esta e futuras pesquisas, principalmente àquelas que visam compreender o porquê do apagamento de uma instituição que um dia foi a joia rara da educação de Ribeirão Preto:

- Catálogo das fotografias avulsas com descritores icônicos e formais ${ }^{17}$;

- Catálogo dos álbuns e almanaques;

- Índice de artigos de jornais de 1950 a 1980 que citam os parques;

- Inventário da documentação depositada nas caixas do Arquivo que falam sobre os parques da cidade; e

- Lista de Leis, Decretos e Resoluções sobre os parques infantis de Ribeirão Preto.

Esses instrumentos de pesquisa estão disponíveis no DVD de dados em anexo ${ }^{18}$ e a partir deles os próximos capítulos foram moldados. É importante frisar que as informações foram

\footnotetext{
${ }^{16}$ Os descritores icônicos registram os elementos figurativos e espaciais e os descritores formais identificam o tratamento plástico.

${ }^{17}$ Foi criado também um slideshow com as fotografias avulsas dos parques infantis de Ribeirão Preto.

Disponível em: 〈https://www.youtube.com/watch?v=yKObyQIPYj0〉. Acesso em: 15 mar. 2015.

${ }^{18}$ Ou podem ser solicitados via e-mail: bia.prandi@usp.br.
} 
contextualizadas, pois o que hoje é objeto de história (colocado para e pela sociedade) e memória (reação que o fato causa no indivíduo/grupo) antes foi produção ativa de um determinado momento.

No próximo capítulo, Os parques infantis de Ribeirão Preto, serão apresentados todos os parques criados na cidade, contextualizando historicamente a conjuntura do local em que foram inseridos, uma vez que os parques de Ribeirão Preto não são exatamente iguais aos parques da cidade de São Paulo da época de Mario de Andrade, no que se refere ao que eram oferecidos neles, suas propostas, atividades e também suas localizações. Esses dados foram coletados através de fontes oficiais encontradas principalmente no Arquivo Público e Histórico de Ribeirão Preto, como fotografias, álbuns, matérias de jornal, relatórios e almanaques. Vale ressaltar que, nesse capítulo, procurou-se não problematizar as fontes, e sim divulgar o que elas propagavam na época dos parques.

No capítulo 3, intitulado Sistematizando fontes e dados para uma discussão sobre a construção de imagens públicas, as fontes utilizadas no capítulo anterior foram problematizadas e alguns dados foram sistematizados para abrir caminhos para pensar a imagem pública construída pelas administrações municipais de Ribeirão Preto das décadas de 1950 e 1960.

O último capítulo, a partir das fontes de memória coletadas nos capítulos anteriores, trará algumas considerações finais e procurará responder sobre o quanto a imagem pública construída pela administração de Ribeirão Preto impregnou e contribuiu para a construção de uma memória desses parques. 


\section{OS PARQUES INFANTIS DE RIBEIRÃO PRETO}

Ribeirão Preto durante muito tempo foi a cidade expoente de uma região reconhecida pela sua participação na economia do café. Isso, durante a Primeira República, foi a marca do reconhecimento da cidade. Entretanto, o município que abrigou os parques infantis das décadas de 50 e 60 em diante é bem diferente.

$\mathrm{Na}$ realidade, Ribeirão Preto já foi esquadrinhada, sobretudo do ponto de vista historiográfico, sob diversos aspectos. Entretanto, para este trabalho, é interessante sublinhar as condições da cidade nas décadas de 50 e 60, pois já não se é mais uma cidade da Primeira República.

A crise de 1929 na região afetou principalmente a metalúrgica e a produção de café. Imediatamente após a quebra da Bolsa, o preço da saca de café chegou a cair $60 \%$. [...] Uma saída encontrada por alguns produtores foi abandonar as desgastadas plantações e se dirigirem ao estado do Paraná, incentivados pelos períodos de preços ascendentes. [...] Os cafeicultores que permaneceram na região ribeirão-pretana tiveram sua situação remediada pelas políticas do governo de Washington Luiz e posteriormente, do governo Vargas. [...] Outros abandonaram a cultura cafeeira erradicando as plantações e passaram a se dedicar ao cultivo da cana-de-açúcar, logo nos primeiros anos após a crise. Um exemplo é o da família Junqueira. (PINTO, 1997, p. 33).

Segundo Luciana Suarez Galvão Pinto (1997), enquanto a atividade cafeeira enfrentava períodos difíceis, o número de operários em Ribeirão Preto só aumentava: em 1938 havia 2.066 operários na cidade; dez anos depois esse número aumentou para 5.400 e, em 1951 (ano da inauguração do primeiro parque infantil da cidade), chegou a 7.000 operários.

A crise cafeeira no entre guerras conduziu mudanças na agricultura da região Nordeste do Estado, em favor do algodão e, posteriormente, da cana de açúcar. Todavia, Ribeirão Preto manteve-se como um polo regional em termos da oferta de bens e serviços, muito procurado pelos moradores de outras cidades da região. [...] De 1890 a 1962, o país passou de um país predominantemente agrário para industrial.

A vida na cidade de Ribeirão Preto atraiu rapidamente um grande contingente de pessoas, pois, já no censo de 1940, 60.2\% dos habitantes viviam nesse meio. Vinte anos mais tarde, a taxa de urbanização chegou a $81.1 \%$, enquanto no Estado de São Paulo ela foi de $62.8 \%$. Até mesmo uma parte considerável dos trabalhadores rurais - tanto os permanentes como os volantes, que são denominados 'boias-frias' - e os fazendeiros passaram a residir nas cidades. Assim, reforçou-se a importância da sociedade urbana. A procura pela moradia na cidade decorreu da criação de boas condições de infraestrutura (água, saneamento, transportes, educação, comunicação, saúde e lazer) e, ao contrário de outras cidades brasileiras, não tanto da industrialização, mas de um significativo setor terciário. Este último setor oferece um leque amplo e qualificado de bens e serviços. (GARAVAZZO; MARCONDES, 2004, p. 257). 
Percebe-se então que Ribeirão se tornou uma cidade referência na região da Alta Mogiana e que atraía moradores devido a sua boa infraestrutura, tanto que, de acordo com o XXX volume da Enciclopédia dos Municípios Brasileiros (IBGE, 1958), no começo da década de 50, Ribeirão Preto estava em $6^{\circ}$ lugar na lista dos municípios mais populosos do Estado de São Paulo,

sendo apenas suplantado por São Paulo, Santos, Campinas, Santo André e Sorocaba. De acordo com o Censo de 1950, estavam presentes 92160 pessoas (45578 homens e 46582 mulheres), sendo 61214 na zona urbana, 4120 na zona suburbana e 26826 ou $29 \%$ na zona rural. A estimativa do D.E.E. de 1-VII1955, acusou 103103 habitantes. (IBGE, 1958, p. 33).

Em relação às aglomerações urbanas, de acordo com IBGE (1958, p. 33), em 1958 eram:

- Sede municipal com 63312 habitantes;

- Distrito de Bonfim Paulista com 976 habitantes;

- Distrito de Dumont com 889 habitantes; e

- Distrito de Guatapará com 157 habitantes.

As atividades econômicas que movimentavam a economia municipal não eram somente a criação de gado (início da história de Ribeirão Preto), ou apenas a economia cafeeira. Em 1956, a agricultura, pecuária e silvicultura, e indústrias de transformação eram bastante importantes para a economia de Ribeirão Preto.

Ribeirão Preto é um ativo centro industrial e está colocado entre os dez municípios paulistas mais importantes, quanto ao valor da produção. Os grupos mais representativos das indústrias de transformação são: indústrias têxteis, indústrias de bebidas e indústrias de produtos alimentares. Entre a classe 'indústria de bebidas' destaca-se o subgrupo 'fabricação de cerveja e outras bebidas maltadas'. Os subgrupos mais importantes da classe dos produtos alimentares estão constituídos de 'fabricação de açúcar deusina' (inclusive subprodutos de cana-de-açúcar) e 'pasteurização e frigorificação do leite'. (IBGE, 1958, p. 34).

Com a consolidação de Ribeirão Preto como centro comercial, financeiro e de serviços, a evolução positiva da economia manteve-se nas décadas de 50 e 60, especialmente nas atividades de assistência médico-sanitária e educacionais.

Em relação à assistência médico-sanitária, Ribeirão Preto da década de 50 tinha reconhecidamente um dos mais notáveis centros médicos do interior paulista. De acordo com o IBGE (1958), seus estabelecimentos hospitalares eram modernos e abrigavam enfermos de todas as cidades vizinhas e também dos mais diversos pontos do país. A cidade contava com: 
de puericultura; 1 centro de saúde; 1 dispensário de tuberculose, 1 inspetoria de profilaxia da lepra; 1 posto de tracoma; 1 dispensário de tracoma; 1 posto de profilaxia da febre amarela; 1 posto de profilaxia da malária; 7 asilos e recolhimentos; 16 de associações de caridade; 68 farmácias; 154 médicos; 145 dentistas; 91 farmacêuticos e 4 veterinários. (IBGE, 1958, p. 35).

Pode-se dizer que, na década de 50, Ribeirão Preto foi um dos mais completos centros de cultura do Estado de São Paulo. Os estabelecimentos de ensino do município proporcionavam educação e cultura não só a estudantes locais, como também a estudantes de diversos pontos do país. Segundo o IBGE (1958, p. 35), os estabelecimentos de ensino existentes à época eram:

- Ensino primário - 176 unidades escolares;

- Ensino secundário - 9 cursos do $1.0\left(1^{\circ}\right)$ ciclo e 4 cursos do $2.0\left(2^{\circ}\right)$ ciclo;

- Ensino pedagógico - 6 cursos normais e um curso de aperfeiçoamento;

- Ensino superior - 5 cursos;

- Ensino comercial - 7 cursos;

- Ensino artístico - 18 cursos;

- Ensino eclesiástico - 6 cursos;

- Ensino industrial - 21 cursos;

- Outras modalidades de ensino - 38 cursos.

De acordo com o IBGE (1958, p. 36), o principal estabelecimento de ensino secundário era o Instituto de Educação Otoniel Mota, e os principais estabelecimentos de ensino superior eram:

- Faculdade de Medicina da Universidade de São Paulo;

- Faculdade de Farmácia e Odontologia;

- Faculdade de Ciências Econômicas;

- Escola de Enfermagem da Universidade de São Paulo; e

- Seminário superior para formação de sacerdotes católicos.

A Faculdade de Medicina constitui notável centro de pesquisas médicas e de investigações científicas, cujas especialidades significam o maior estímulo para atrair interessados de toda a zona interiorana, desde que o é também para cientistas dos grandes centros metropolitanos e até do estrangeiro. Sua Escola de Enfermagem está em pleno funcionamento e o modelar Hospital das Clínicas constitui uma instituição de grande significação regional. (IBGE, 1958, p. 36).

Do ponto de vista da educação, Ribeirão Preto então era consolidada como um município que abrigava universidades e escolas estabilizadas, diversas escolas particulares, 
rede municipal já em constituição, além de expansão em sua rede estadual. Dessa forma, o nível de instrução geral dos habitantes, revelado pelo Censo de 1950 era, para maiores de 5 anos, $69 \%$ de alfabetizados. (IBGE, 1958, p. 35).

Vale lembrar que "Ribeirão Preto detinha uma posição ao redor do vigésimo lugar entre os municípios brasileiros em termos do Índice de Desenvolvimento Humano, que reflete a renda familiar per capita, esperança de vida ao nascer e o nível educacional”. (GARAVAZZO; MARCONDES, 2004, p. 257).

Nota-se que os estabelecimentos de ensino primário totalizavam 176 unidades escolares (grupos escolares e parques infantis). Dessa maneira, Ribeirão Preto havia se tornado uma cidade referência em certa região do interior paulista, consideravelmente aparelhada de escolas públicas e particulares. A partir desse cenário, a diferença dos parques em relação a tudo que havia na cidade era realçada, pois esses ambientes não eram escola primária, nem pré-escola, tampouco jardim de infância: eram simplesmente parques infantis com um modelo muito próprio se comparado ao que havia de escolas até então.

É importante destacar que os parques infantis surgiram na década de 1930 na cidade de São Paulo e tinham como objetivo promover, através da recreação, educação e assistência. Sua implantação justifica-se porque:

[...] era necessário retirar crianças e adolescentes das ruas para que não acabassem sendo 'contaminadas' pelo vício e pela criminalidade e, outrossim, sob a justificativa de que era preciso minorar, por meio de uma ação institucional, as precárias condições higiênicas e de saúde dos filhos de famílias pobres residentes em bairros operários. [...] Apesar de sua construção remontar a 1931, os parques infantis permaneceram desativados até 1935, quando passaram por grandes transformações. Incorporados em meados de 1935 pela 'inteligência paulista' e pelos constitucionalistas à esfera do Departamento de Cultura, os parques infantis foram transformados em instituições de educação extraescolar com o propósito de acolher filhos de famílias operárias que estivessem na faixa etária de 3 a 12 anos, a fim de que lhes fossem fornecidas educação, assistência e recreação. (SILVA, C., 2008, p. 57).

No jornal ribeirão-pretano Diário da Manhã de 03 abril de 1949 por meio do artigo intitulado "Água mole em pedra dura tanto bate até que fura", o promotor público Dr. José de Almeida Peixe Abbade clama:

[...] E porque Ribeirão Preto não poderá possuir o seu Parque Infantil? Se os Srs. Vereadores pensam que é muito dispendiosa a construção e a instalação de um Parque Infantil, poderão solicitar da Assembleia Legislativa por intermédio dos Srs. Deputados da zona, o respectivo auxílio negado.

Avante Srs. Vereadores e Sr. Prefeito! A população inteira desta bela e importante cidade estará, estou certo, com os Egrégios legisladores da Câmara 
Municipal de Ribeirão Preto e com seu Prefeito, que sancionará a lei, no sentido de que as crianças desta formosa cidade possam, mais tarde, levantar louvores a Deus por tê-los inspirado na realização de tão nobilizante iniciativa. (DIÁRIO DA MANHÃ, 1949, p. 5).

Nota-se que a demanda pelos parques infantis tinha um porta-voz local ${ }^{19}$ que, além de posicionar-se como advogado de uma causa necessária ao todo da sociedade ribeirão-pretana, ainda indicava os caminhos da burocracia estatal e dos poderes públicos a quem se poderia recorrer, com o adicional de mostrar aos políticos da cidade os dividendos eleitorais possíveis.

Dessa maneira, os parques infantis começaram a ser implantados em Ribeirão Preto em $1951^{20}$, durante o mandato do prefeito José Magalhães ${ }^{21}$, por influência do Departamento de Educação Física do Estado de São Paulo, com um discurso modernista de proporcionar às crianças da cidade recreação, atenção à saúde com atendimento médico e odontológico, cuidados higiênicos e, sobretudo, educação física, pois, da forma como foram concebidos e propostos por esse departamento, possuíam "um sentido amplo que propugnava a ideia de atividades físicas recreativas diversas, com conteúdo de fundo moral, cívico e médicohigienista, que tinha como objetivo promover a saúde de forma articulada com a ideia de educação integral da criança”. (MICARONI, 2007, p.16).

Desde a inauguração do primeiro estabelecimento, nota-se que o modelo paraescolar ${ }^{22}$ representado pelos parques infantis foi prontamente difundido em Ribeirão Preto de tal maneira que, em menos de dez anos, havia sete parques infantis na cidade:

\footnotetext{
${ }^{19}$ Peixe Abbade não era apenas um porta-voz popular, mas um promotor público que tinha o desejo de contar com um aparelho semiescolar capaz de educar as crianças das famílias pobres, tanto que, em sua homenagem, em 05 de julho de 1955 pela Lei no 443 de Ribeirão Preto (RIBEIRÃO PRETO, 1955c), o Parque Infantil do Barracão, tanto apoiado pelo promotor, foi denominado Parque Infantil Peixe Abbade.

${ }^{20}$ O primeiro parque infantil em Ribeirão Preto, Peixe Abbade (bairro do Barracão, atual bairro do Ipiranga), foi inaugurado em 08 de janeiro de 1951. De acordo com o jornal A Tarde, esse parque atendia a oitocentas crianças com benefício de "suprir uma sensível lacuna e dar vida ao bairro do Barracão, que sempre viveu abandonado pelo poder público”. (A TARDE, 1952, p. 1).

${ }^{21}$ É importante, para a compreensão do trabalho, realizar uma contextualização política do município, indicando os gestores da cidade nos períodos abordados $\mathrm{O}$ primeiro parque infantil de Ribeirão Preto foi implantado pelo prefeito José de Magalhães (mandato: 1948-1951). Logo após inaugurar o Parque Infantil Peixe Abbade, Magalhães foi sucedido pelo prefeito Cel. Alfredo Condeixa Filho (vice-prefeito durante a gestão anterior; também o primeiro prefeito eleito após a promulgação da Constituição Federal de 1946). No entanto, Condeixa Filho renunciou ao cargo, tendo seu mandato concluído por José Costa (mandato: 1952-1955). Em 1955 o prefeito Costabile Romano foi eleito (mandato: 1956-1959), mas também teve de se ausentar da prefeitura para concorrer às eleições para Deputado Estadual, sendo eleito. Seu sucessor foi Áureo Norberto da Silva. Em 1960, Cel. Alfredo Condeixa Filho voltou à prefeitura e ficou até 1964, quando Dr. Welson Gasparini foi eleito (mandato: 1964-1967, prorrogado até 1969). Em 1969 Dr. Antônio Duarte Nogueira assumiu a prefeitura e permaneceu até 1973, na ocasião em que Dr. Welson Gasparini retornou ao cargo (1973-1977). Em 1977, Dr. Antônio Duarte Nogueira quem voltou e assumiu o cargo até 1983 (mandato: 1977-1983). Em 1984 foi João Gilberto Sampaio quem assumiu a prefeitura (mandato: 1983-1988).

${ }^{22}$ As instituições que seguem modelos paraescolares não tomam o lugar da escola e nem a negam, e sim se conectam em parte a ela, pois atuam sobre a infância escolar, não se organizando rigorosamente como a escola de então, principalmente porque atendem crianças no turno antes ou após a escola regular.
} 
1. Parque Infantil Peixe Abbade, inaugurado em 08 de dezembro de 1951;

2. Parque Infantil Amélia Junqueira, conhecido como Parque Infantil do Bosque, inaugurado em 12 de maio de 1953;

3. Parque Infantil Anita Procópio Junqueira; inaugurado em 08 de dezembro de 1954;

4. Parque Infantil Dona Iria Junqueira, conhecido como Recanto $4^{\circ}$ Centenário, em Bonfim Paulista, criado em 11 de julho de 1955.

5. Parque Infantil de Dumont ${ }^{23}$, provavelmente inaugurado em 1956;

6. Parque Infantil de Guatapará ${ }^{24}$, provavelmente inaugurado em 1956;

7. Parque Infantil Santa Maria Goretti ${ }^{25}$, inaugurado em 05 de janeiro de 1959; e

Ainda nessa década, as vantagens para a infância, principalmente para os filhos das famílias pobres, eram propagandeadas na imprensa local, como em 24 de setembro de 1955, quando o jornal A Tarde publicou um artigo de Pontes de Marais, que já havia sido publicado pelo SPES de São Paulo, expondo as opiniões do autor sobre os parques infantis e assistência à infância realizada nesses locais:

Um dos problemas mais angustiantes do Brasil, e do qual não escapa nosso Estado, apesar de seu elevado teor e econômico é o da assistência à infância. Se corrermos a vista pelas organizações oficiais ou privadas destinadas ao amparo da infância vemos que uma apresenta grande destaque - o parque infantil - onde as crianças além de aprenderem alguma coisa e serem arrebatadas aos perigos das ruas, recebem uma alimentação mais ou menos apreciável.

Esses estabelecimentos dos quais a capital paulista conta com quase duas dezenas, têm função relevante na educação de milhares de menores, na sua totalidade filhos de operários que em casa, restringem ao máximo os seus elementos alimentares pois que precisam desviar para outras despesas inevitáveis uma parcela respeitável dos seus salários.

\footnotetext{
${ }^{23}$ De 1953 a 1963 Dumont foi distrito de Ribeirão Preto, entretanto, em razão da Lei no 8050 , de 31 de dezembro de 1963 (SÃO PAULO, 1963), que dispõe sobre o quadro territorial, administrativo e judiciário do Estado, o distrito de Dumont se transformou em município.

${ }^{24}$ Guatapará foi distrito de Ribeirão Preto até 09 de janeiro de 1990, quando a Lei Estadual n 6645 (SÃO PAULO, 1990), que dispõe sobre alterações no quadro territorial administrativo do Estado, transformou Guatapará em município do Estado de São Paulo.

${ }^{25}$ Darahem (2011, p. 42) aponta que "professores, ordens e figuras religiosas (tanto da cidade como Santos reconhecidos pela Igreja Católica), pessoas socialmente notórias, figuras importantes na ciência brasileira e mundial, dentre outros, são geralmente homenageados com escolas que recebem seu nomes" e em Ribeirão Preto com os parques infantis não foi diferente: nota-se que, dos 7 parques citados, com exceção dos parques de Guatapará e Dumont (sobre os quais não temos muitas informações), 1 tem nome de um promotor público da cidade (Peixe Abbade), 1 tem nome de santa (Santa Maria Goretti) e 3 prestaram homenagens a mulheres da família Junqueira: Amélia Junqueira, Anita Procópio Junqueira e Dona Iria Junqueira. A família Junqueira tinha muito prestígio na época de ouro no café de Ribeirão Preto e "resultou em diversas homenagens em forma de nomes de importantes vias públicas de Ribeirão Preto e, como não poderia deixar de ser, de nomes de escolas. As mulheres Junqueira, geralmente benfeitoras envolvidas em projetos de caridade, são maioria dos nomes de escolas de Educação infantil”. (DARAHEM, 2011, p. 42).
} 
E o parque infantil, que devia merecer dos governos municipais grossas verbas, ou preenche de maneira mais ou menos eficiente, e indireta, a lacuna aberta pela insuficiência de comida nos lares, pois que tais crianças nos parques infantis recebem alimento, além de assistência dentaria, médica e ensino em seus variados aspectos.

Por essa razão as vagas nesses estabelecimentos são disputadíssimas. Milhares de pais proletariados procuram neles a solução do seu problema, precisam trabalhar e geralmente os dois membros do casal saem pela manhã e voltam à noite, deixando os filhos entregues à própria sorte ou confiados à guarda do mais velho - cuja idade raramente vai além dos doze anos.

Dessa situação os trabalhadores procuram fugir matriculando os filhos nos parques infantis, cuja missão avulta, pois que passam a fazer o honroso papel de babás dessas crianças que, de outra maneira, fariam nas ruas um curso completo de vagabundagem, que as habilitariam ao ingresso na universidade do crime.

Daí a necessidade dos governos municipais das grandes cidades reservarem grandes verbas, não somente para o aprimoramento dos parques existentes, como também para a criação de muitos outros, que venham atender às necessidades de dezenas de milhares de operários que, com o seu trabalho honrado lutam pela grandeza do Estado e o da coletividade.

As autoridades têm nos parques infantis o veículo de que necessitam para distribuir, às mancheias, a assistência a que as crianças fazem jus, como capital radioso que são e que mais tarde pagarão, com sua eficiência, juros polpudos do capital que neles se empregar. (A TARDE, 1955, grifo nosso).

No caso acima, o autor faz menção aos parques infantis da capital, que foram base para a instalação dos parques do interior de São Paulo, mas que se diferiam em alguns pontos, uma vez que a alimentação nos parques de Ribeirão era um dos pontos mais elogiados, ao passo que os de São Paulo não.

Outro exemplo de vantagens de um parque infantil, dessa vez para a população ribeirãopretana, foi publicado em 1954 também pelo jornal A Tarde:

[...] o que representa um parque infantil para a coletividade, normalmente para filhos de operários, ou trabalhadores braçais, inclusive domésticos foge do comentário rápido de uma notícia, mas merecendo estudo profundo de grandes proporções para o perfeito equilíbrio do mundo de amanhã. Nos parques infantis do Barracão e dos Campos Elíseos cerca de 2,500 crianças têm hoje, uma visão diferente da vida. Recebem instrução, alimentação, vestimenta e assistência médica. Isso é um programa completo de boa administração. Daí a atenção devida que o parque infantil merece por parte da administração. Ainda teremos, em breve 5,000 crianças 'parquizadas' e isso será de alta valia, com resultados imprevisíveis para a coletividade. (A TARDE, 1954, p. 1).

Os números contabilizados no jornal, por sua vez, fazem sentido se vistos como evidências do alcance do programa de ação assumido progressivamente pelos parques. A ênfase no jogo, na recreação e na educação física constam como diretrizes pedagógicas, desde os primeiros projetos sugeridos pelo Departamento de Educação Física de São Paulo à Prefeitura 
de Ribeirão Preto, ao passo que, localmente, a cultura dos cuidados higiênicos e sanitários preencheu outra parte importante da pauta de suas atividades cotidianas.

\subsection{O que era oferecido nos parques ribeirão-pretanos? ${ }^{26}$}

\subsubsection{Educação física e recreação}

De acordo com Micaroni (2007, p. 14), o conceito de educação física no período dos parques "possuía um sentido amplo que propugnava a ideia de atividades físicas recreativas diversas, com conteúdo de fundo moral, cívico e médico-higienista, que tinha como objetivo promover a saúde de forma articulada com a ideia de educação integral da criança”.

Ferreira (2011) entrevistou 5 ex-professoras da Educação Infantil de Ribeirão Preto, dentre as quais as entrevistadas 1 e 3 foram ex-professoras de parques infantis. A entrevistada 3 trabalhou de 1956 a 1964 como recreacionista do Parque Infantil Peixe Abbade. Ela conta que durante esses anos era incentivada a participar de cursos de recreação em São Paulo para atualizar suas aulas. Conta que ia de duas a três vezes por ano participar desses cursos, o que mostra que havia uma preocupação com a qualidade das aulas de recreação. Narra também que as atividades aplicadas eram natação, futebol, atletismo e leitura; e que enquanto dava recreação pra uns, orientava os outros no reforço.

De acordo com Daisy, ex-professora do Parque Infantil Peixe Abbade, entrevistada por Darahem (2011), as professoras recebiam treinamento para conduzir atividades físicas às crianças e que não as deixavam simplesmente brincar, o que pode-se perceber na figura 1 , a qual mostra uma professora do Parque Infantil Amélia Junqueira treinando as crianças do parque em uma quadra de basquete com exercícios próprios de educação física, denominados exercícios calistênicos ${ }^{27}$, os quais, nesse caso, exigem postura e ordem, uma "posição" perfeita para ser fotografada. Além disso, esses exercícios podem ser usados,

[...] tanto nos esportes como no militarismo, como forma de condicionamento em grupo, de forma sincronizada (como uma rotina de 'chamada e resposta', onde o exercício é feito por um instrutor e seguido pelos demais participantes), com o objetivo de aumentar a coesão e disciplina do grupo. Os calistênicos

\footnotetext{
${ }^{26}$ Nesse item procuramos não problematizar as fontes e sim divulgar o que elas propagavam. No capítulo 3 as fontes serão problematizadas.

${ }^{27}$ Exercícios calistênicos são exercícios que utilizam como principal recurso o próprio corpo. Os parques infantis não tinham "aparelhos" para ginástica, apenas aparelhos para recreação. Dessa maneira, o corpo e a bola eram os únicos instrumentos usados pelas professoras para educação física dessas crianças.
} 
também são populares na educação física no período escolar. (OGROFIT, $2011)^{28}$.

Figura 1 - Educação física no Parque Infantil Amélia Junqueira, setembro de 1961. Foto: Miyasaka

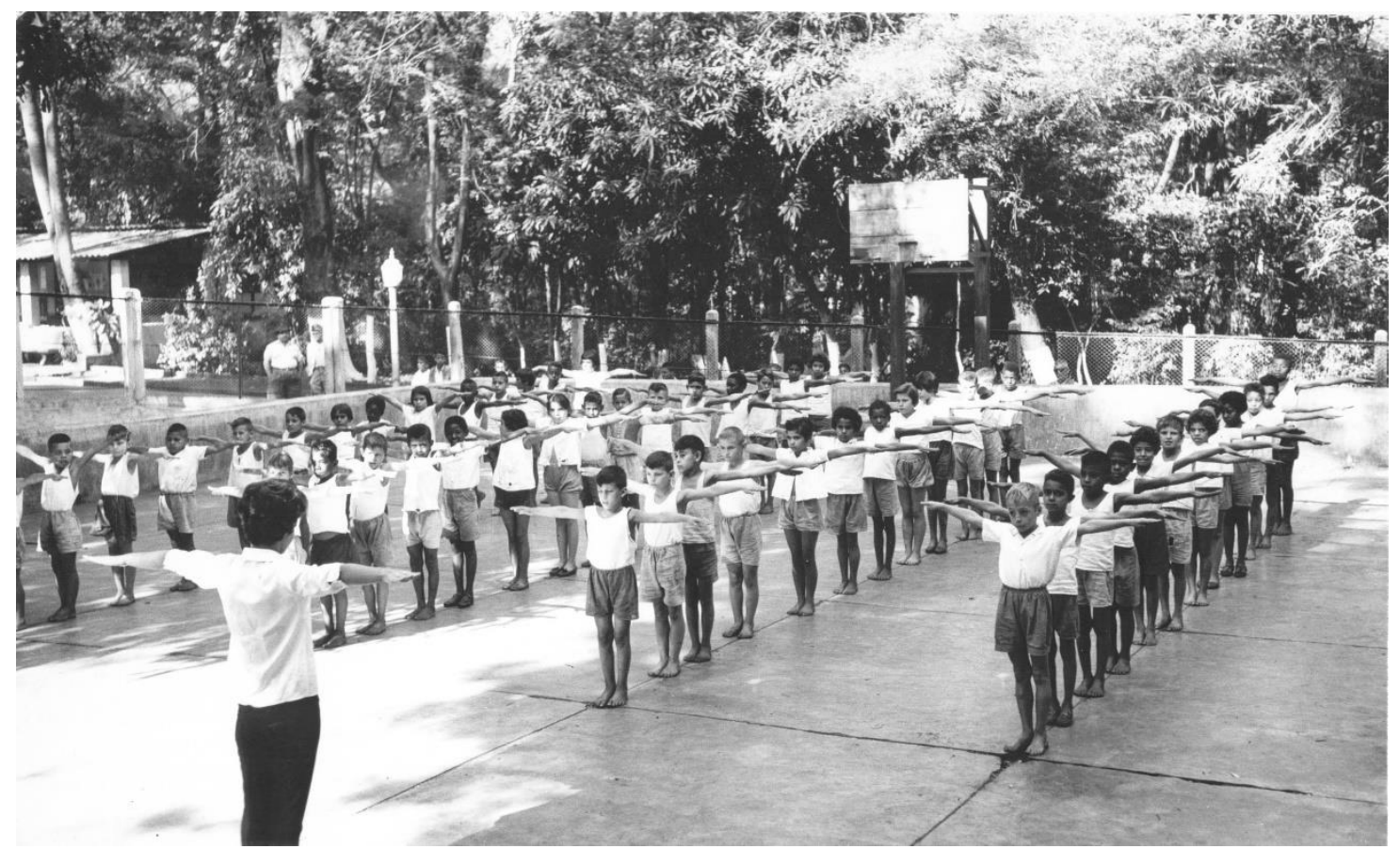

Fonte: Arquivo Público e Histórico de Ribeirão Preto $^{29}$

O interessante dessa foto também é que todas as crianças estão uniformizadas, mas poucas têm os pés calçados (figura 2). De 53 crianças, percebe-se que apenas 6 delas estão com sandálias, calçado que, assim como o pé descalço, não é próprio para tal atividade.

\footnotetext{
${ }^{28}$ Segundo o website Ogrofit (2011), "a história dos exercícios calistênicos vem dos atletas greco-romanos. São originais da Grécia antiga, onde foram relatadas por guerreiros Persas, observando guerreiros Espartanos na Batalha de Thermopylae, quando os Persas interpretaram os movimentos sincronizados dos Espartanos como uma dança. Julgaram-os [sic] como fracos e perderam batalha".

${ }^{29}$ A fotografia pode ser encontrada no Arquivo Público e Histórico de Ribeirão Preto, no fundo Cel. Alfredo Condeixa Filho, na Pasta 51, nº de registro 586.
} 
Figura 2 - Detalhe da figura 1

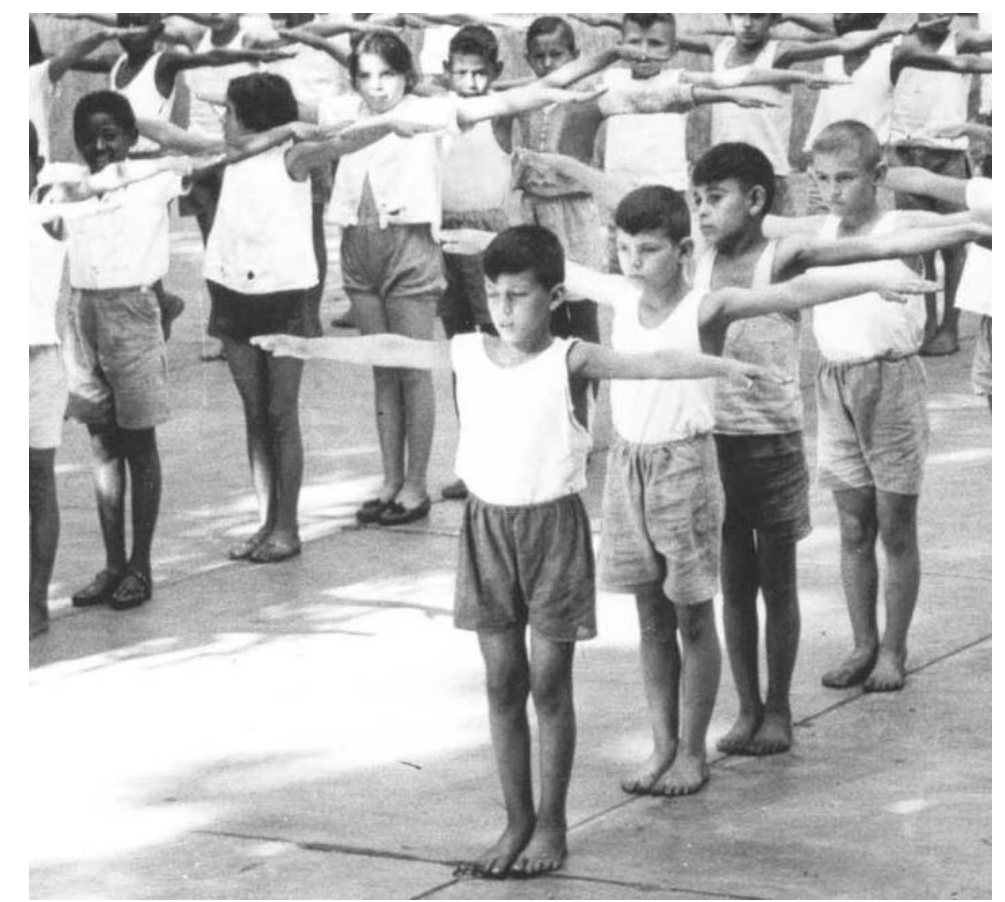

\subsubsection{Assistência médica}

Em razão dos propósitos atribuídos aos parques, as professoras, além de lidarem com atividades lúdicas, também se ocupavam com o cuidado em relação à criança juntamente com as enfermeiras. Realizavam-se vários exames e medidas de prevenção a doenças eram tomadas, um exemplo é a promoção de campanhas contra enfermidades como tracoma, conjuntivite, tuberculose, entre outras. O resultado de uma dessas campanhas foi inclusive publicado no jornal A Tarde no ano de 1953, em relação ao Parque Infantil do Barracão, divulgando para a cidade os benefícios à saúde que a implantação dos parques infantis estava ocasionando:

[...] continuamos a campanha contra o tracoma e a conjuntivite. Os resultados são, no geral, bons, porém são melhores com aquelas crianças que nos ajudaram comparecendo regularmente aos curativos e, com aquelas que seguem as regras de higiene, por nós orientadas (A TARDE, 1953, p. 15).

A partir da figura 3, é possível notar que o ambulatório médico do parque possuía alguns equipamentos necessários para atendimentos pequenos e que era frequentado assiduamente pelas crianças. De acordo com a Entrevistada 3 (FERREIRA, 2011), as professoras e enfermeiras tinham de cuidar da saúde daquelas crianças, pois estas eram muito pobres e não era possível para os pais darem toda assistência necessária a elas. 
Quanta berne que eu e a Matilde... que era enfermeira e já é falecida... tiramos de cabeça de crianças, da barriga. O Dr. João Garcia, ele faleceu há pouquíssimo tempo aqui em Ribeirão...era um pediatra maravilhoso...certo? Então...Tinha uma assistência excelente. Então, na convivência com eles...era aquela carência, bem. Porque era... quando o pai e a mãe trabalhavam tudo bem, certo? Mas era uma pobreza tremenda, eles não tinham o que comer. Comiam no parque as crianças. Não era fácil, não. (FERREIRA, 2011).

Figura 3 - Ambulatório médico do Parque Infantil Peixe Abbade, setembro de 1961. Foto: Miyasaka

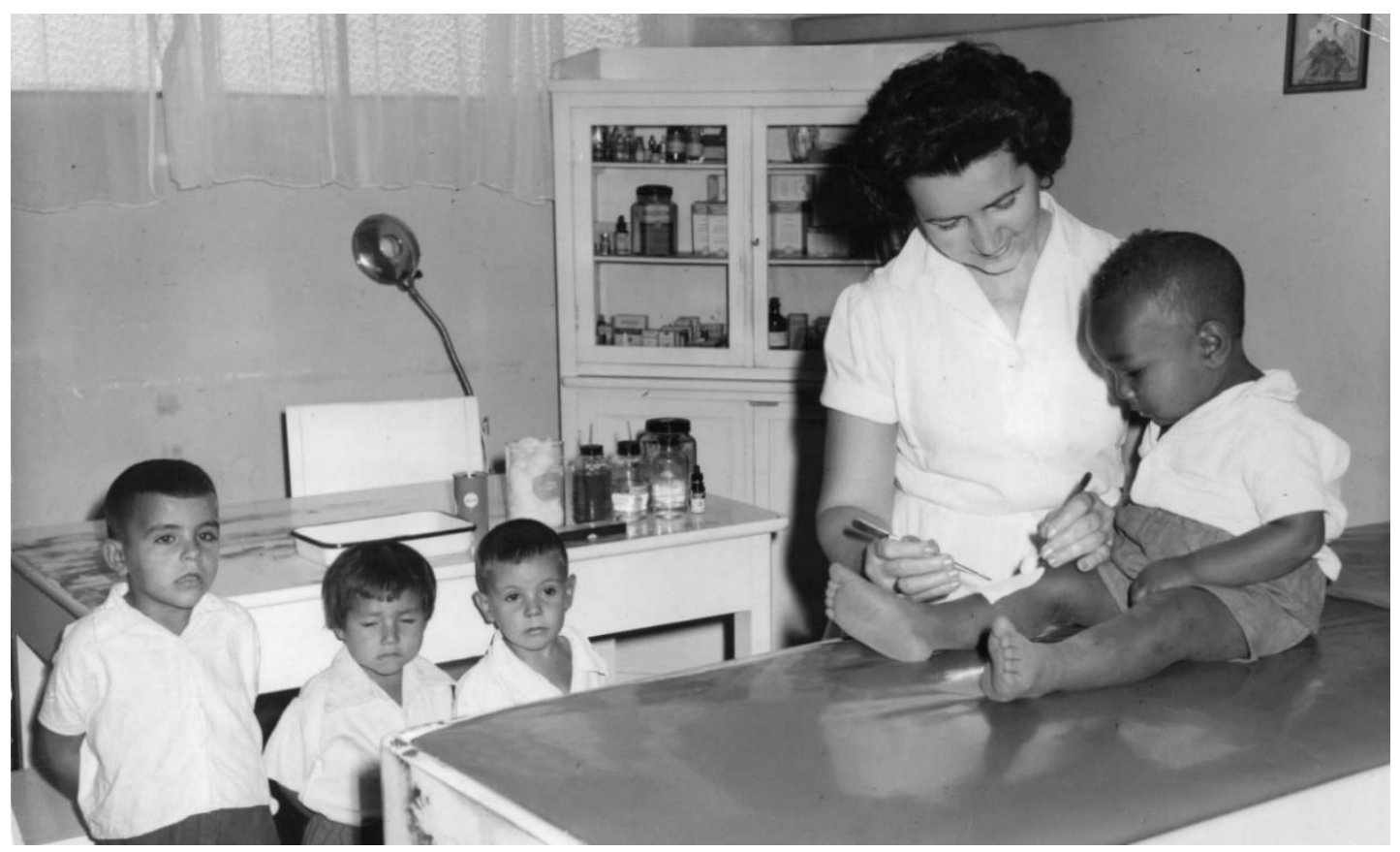

Fonte: Arquivo Público e Histórico de Ribeirão Preto ${ }^{30}$

\subsubsection{Assistência odontológica}

Havia também assistência odontológica nos parques, e era tão importante que foi confeccionado, em 1963, pela chefe da seção médico-social-odontológica de Ribeirão Preto, Augusta Aguiar, o Álbum Histórico e Fotográfico dos Postos Odontológicos do Serviço Dentário Municipal, em homenagem ao então prefeito Cel. Alfredo Condeixa Filho, registrando o trabalho de toda a rede de consultórios dentários e os serviços que prestavam às crianças parqueanas.

Gratos pela oportunidade que tivemos de poder colaborar com o denodado esforço de V. Excelência, no amparo e assistência aos menos favorecidos pela sorte, dando-lhes um alívio na dor, uma graça no sorriso e um futuro sadio; nós, os odontólogos do Serviço Dentário Municipal, levamos-lhe o testemunho de nosso mais profundo apreço. (AGUIAR, 1963).

\footnotetext{
${ }^{30}$ A fotografia pode ser encontrada no Arquivo Público e Histórico de Ribeirão Preto, no fundo Cel. Alfredo Condeixa Filho, na Pasta 87, $\mathrm{n}^{\circ}$ de registro 1078.
} 
Pelo fato de ser fartamente ilustrado por séries fotográficas, o Álbum contém o registro do cotidiano da prática dos cuidados com a higiene bucal, mostrando que cada criança tinha sua escova guardada, com seu nome, por um escoveiro (figura 4). Através das imagens é possível inferir que, para as crianças, aquele era um momento divertido, pois, de acordo com Aguiar (1963), elas esperavam ansiosamente o momento de escovação. Vale ressaltar que toda a rede de consultórios e a prática dos cuidados com a higiene bucal visavam às crianças filhas de famílias pobres e atendidas educacional e assistencialmente pelos parques infantis. Pode-se notar que o momento da escovação era realizado ao ar livre e não individualmente, e sim com uma turma de crianças (figura 5).

Figura 4 - Página do Álbum Histórico e Fotográfico dos Postos Odontológicos do Serviço Dentário Municipal Escoveiros

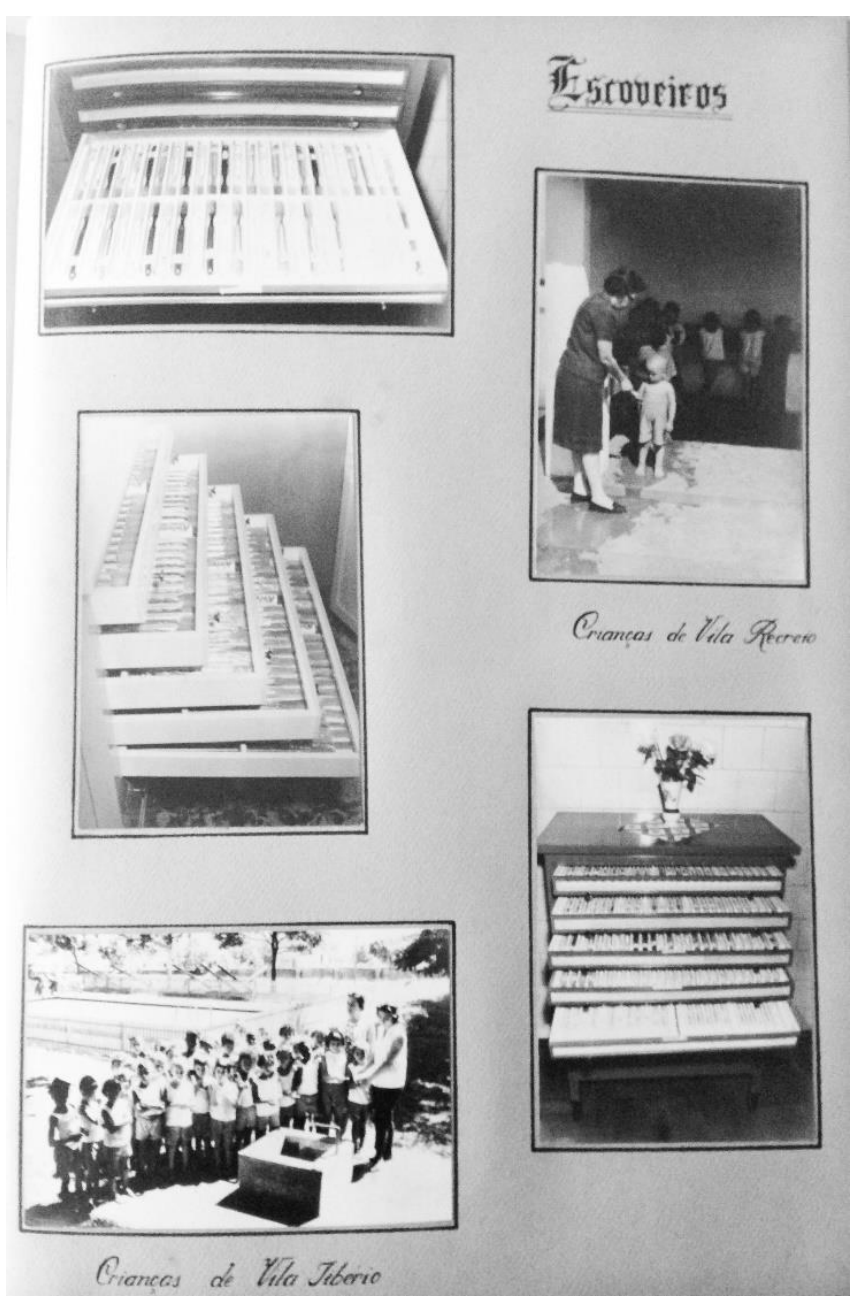

Fonte: AGUIAR $(1963)^{31}$

${ }^{31} \mathrm{O}$ Álbum histórico e fotográfico dos postos odontológicos do serviço dentário municipal de Ribeirão Preto, organizado por Augusta Aguiar em 1963, está depositado no Arquivo Público e Histórico de Ribeirão Preto, no Fundo Cel. Alfredo Condeixa Filho. 
Figura 5 - Crianças do Parque Infantil Peixe Abbade no momento da escovação

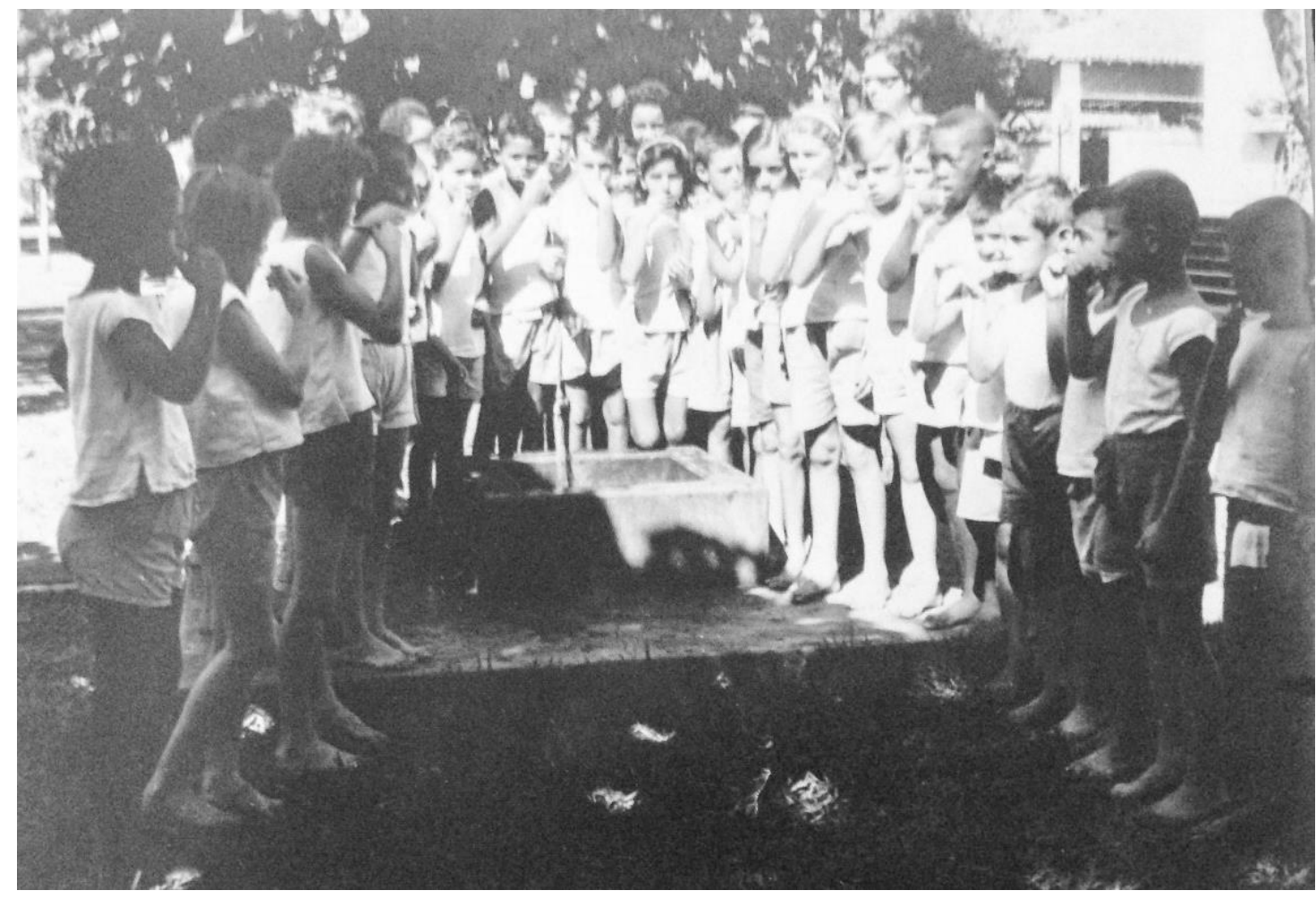

Fonte: AGUIAR $(1963)^{32}$

De acordo com Aguiar (1963), esse atendimento era realizado até 1963 nos Parques Infantis Bandeirantes, Santa Maria Goretti, Anita Procópio Junqueira, Amélia Junqueira e Peixe Abbade.

O Parque Infantil Bandeirantes (figura 6) tinha duas clinicas odontológicas criadas em maio de 1963 pelo prefeito Cel. Alfredo Condeixa Filho: uma diurna que atendia as crianças matriculadas no parque, oferecendo tratamento diário completo; e uma noturna que atendia pessoas pobres, "efetuando inicialmente (em virtude da precaríssima situação em que se encontra a boca dos moradores do bairro) profilaxia com avulsão dos elementos infecciosos da cavidade oral e, em seguida, posterior tratamento dentário completo, aos que necessitarem". (AGUIAR, 1963). No primeiro mês de funcionamento das clínicas foram realizados 319 atendimentos, sendo 167 em crianças do próprio parque.

\footnotetext{
${ }^{32} \mathrm{O}$ Álbum histórico e fotográfico dos postos odontológicos do serviço dentário municipal de Ribeirão Preto, organizado por Augusta Aguiar em 1963, está depositado no Arquivo Público e Histórico de Ribeirão Preto, no Fundo Cel. Alfredo Condeixa Filho.
} 
Figura 6 - Página do Álbum Histórico e Fotográfico dos Postos Odontológicos do Serviço Dentário Municipal assistência realizada no Parque Infantil Bandeirantes

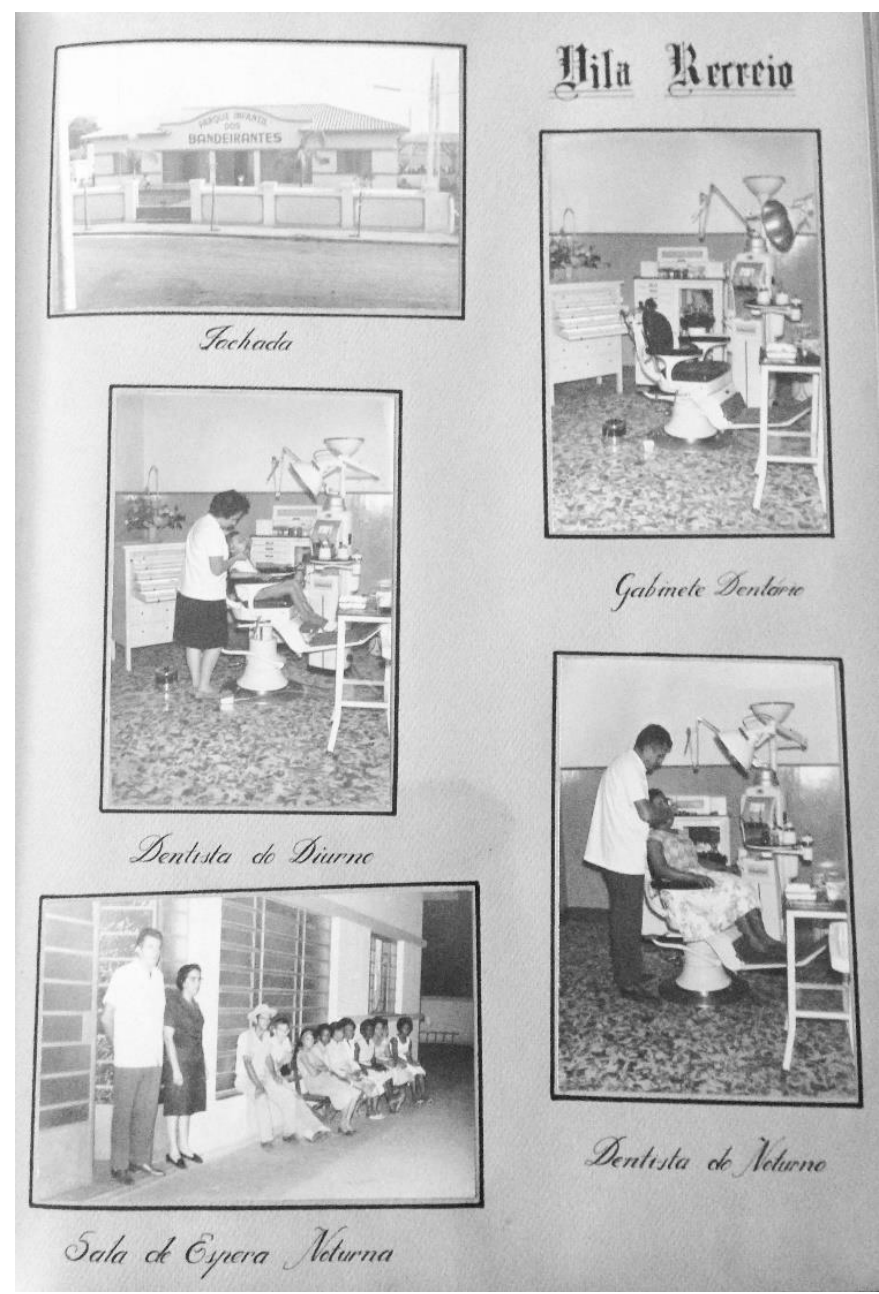

Fonte: AGUIAR $(1963)^{33}$

No Parque Infantil Santa Maria Goretti (figura 7) também havia duas clínicas que foram criadas em janeiro de 1959 pelo prefeito Costabile Romano e em 1960, o prefeito Cel. Alfredo Condeixa Filho instalou um gabinete dentário completo no local. Assim como no Parque Infantil dos Bandeirantes, atendia as crianças, os pobres residentes naquele bairro e também os alunos do curso de Admissão, anexo ao parque infantil. De 1959 a 1963 foram atendidas 14651 pessoas, sendo 5639 crianças do parque.

\footnotetext{
${ }^{33} \mathrm{O}$ Álbum histórico e fotográfico dos postos odontológicos do serviço dentário municipal de Ribeirão Preto, organizado por Augusta Aguiar em 1963, está depositado no Arquivo Público e Histórico de Ribeirão Preto, no Fundo Cel. Alfredo Condeixa Filho.
} 
Figura 7 - Página do Álbum Histórico e Fotográfico dos Postos Odontológicos do Serviço Dentário Municipal assistência realizada no Parque Infantil Santa Maria Goretti

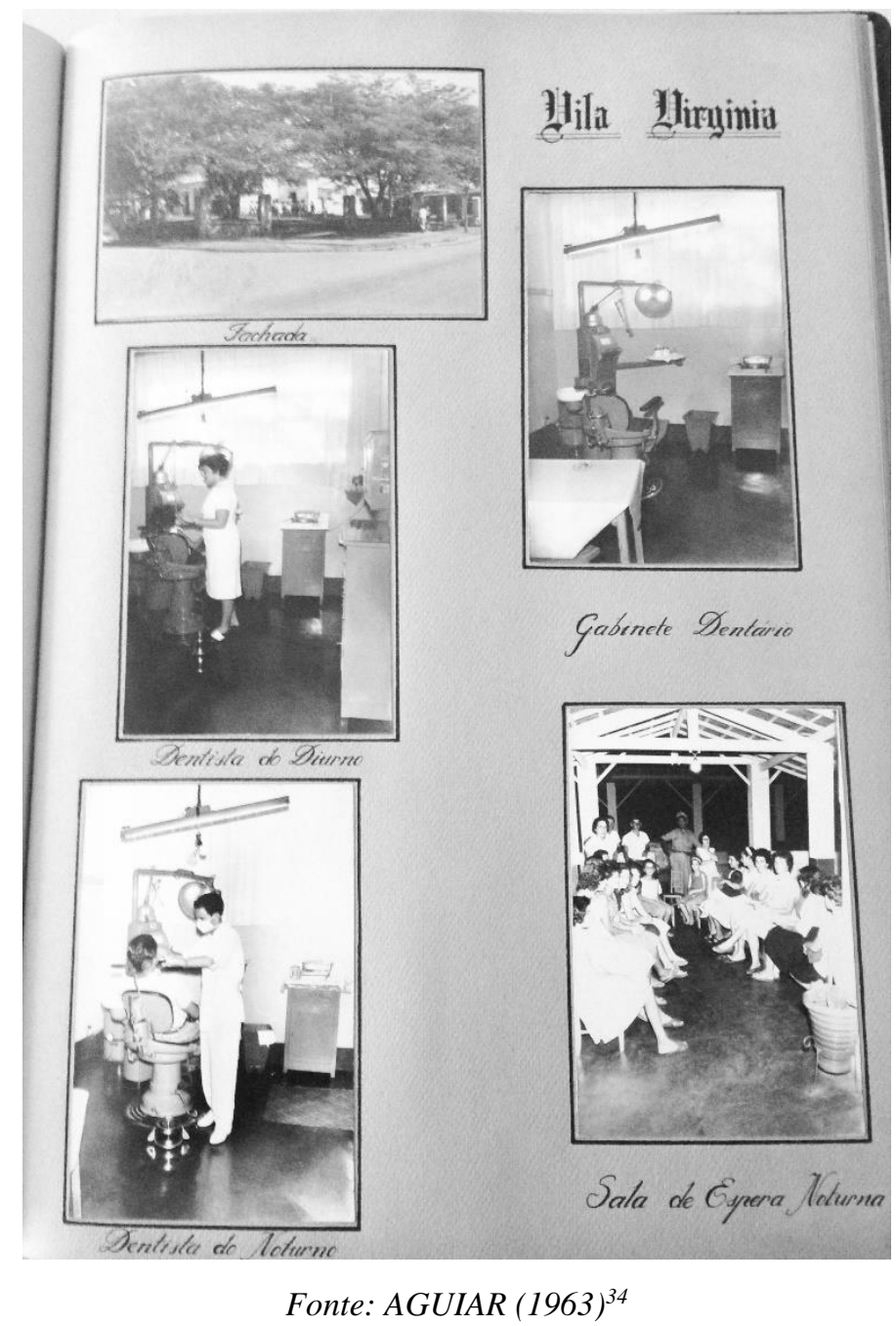

O Parque Infantil Anita Procópio Junqueira (figura 8) tinha uma clínica diurna instalada em 1954 pelo prefeito Cel. Alfredo Condeixa Filho, que oferecia tratamento completo a todas as crianças do parque. Quatro anos depois o prefeito Costabile Romano instalou também uma clínica noturna para efetuar extrações dentárias a pessoas sem recursos. De acordo com o Álbum, em 1963 a clínica diurna atendia também as crianças das Escolas Municipais vizinhas e a clínica noturna continuava não só a oferecer a extração de dente, mas também tratamento dentário completo. De 1954 a 1963, 15921 pessoas foram atendidas, sendo 7411 crianças.

\footnotetext{
${ }^{34} \mathrm{O}$ Álbum histórico e fotográfico dos postos odontológicos do serviço dentário municipal de Ribeirão Preto, organizado por Augusta Aguiar em 1963, está depositado no Arquivo Público e Histórico de Ribeirão Preto, no Fundo Cel. Alfredo Condeixa Filho.
} 
Figura 8 - Página do Álbum Histórico e Fotográfico dos Postos Odontológicos do Serviço Dentário Municipal assistência realizada no Parque Infantil Anita Procópio Junqueira

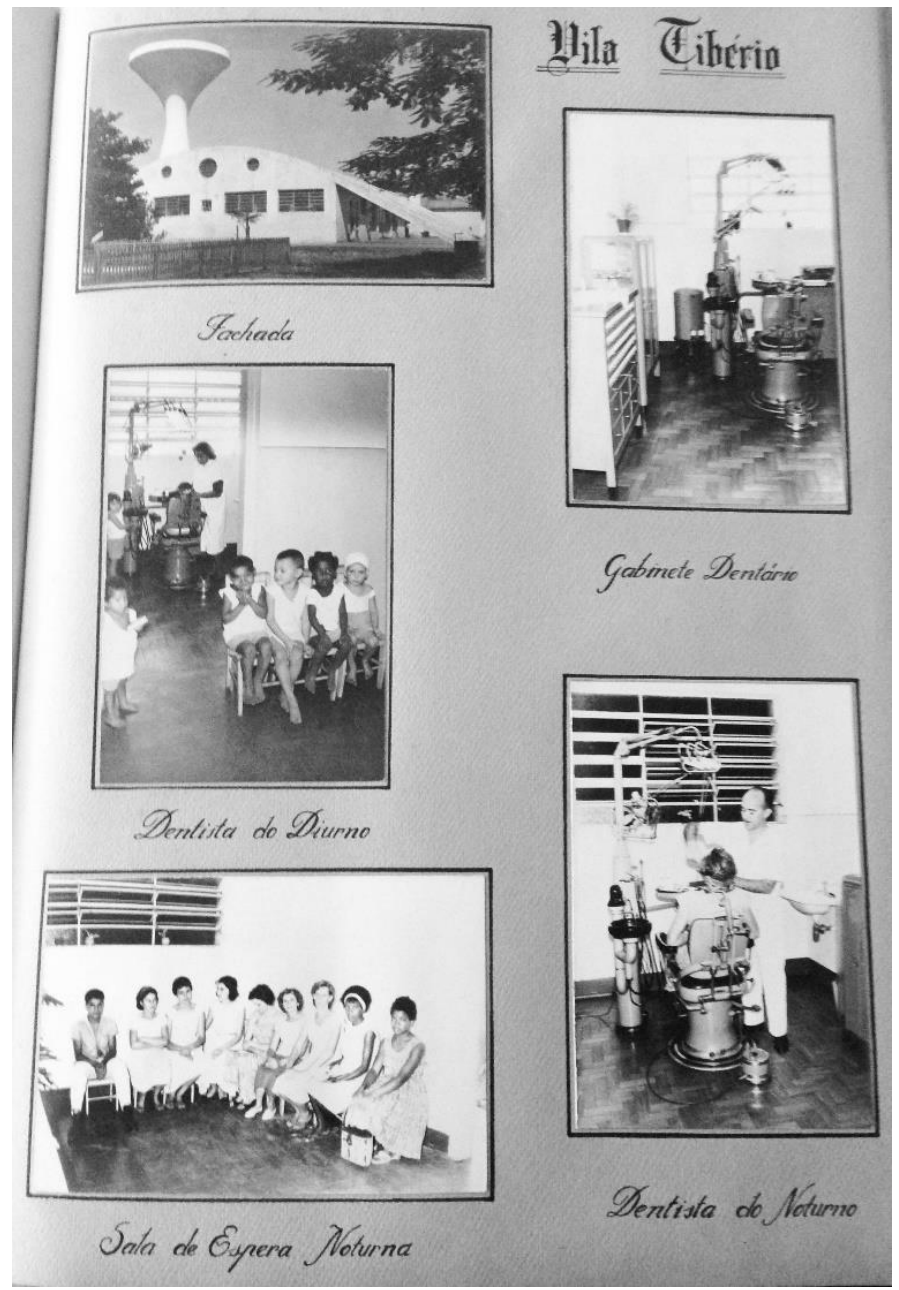

Fonte: AGUIAR $(1963)^{35}$

No Parque Infantil Amélia Junqueira (figura 9) a clínica diurna para as crianças do parque foi instalada em 1953 pelo prefeito Cel. Alfredo Condeixa Filho, e a clínica noturna foi instalada em março de 1961, pelo mesmo prefeito, para atendimento dentário completo aos funcionários da prefeitura e seus familiares. Em 1963 a clínica diurna passou a atender também as crianças do curso primário do Ginásio Municipal dos Campos Elíseos e as escolas municipais vizinhas. A clínica noturna passou a atender a população ribeirão-pretana em geral e a oferecer tratamento completo aos alunos do curso noturno, matriculados no Ginásio Municipal dos Campos Elíseos. De 1953 a 1963 foram realizados 6028 atendimentos, sendo 3517 em crianças.

\footnotetext{
${ }^{35} \mathrm{O}$ Álbum histórico e fotográfico dos postos odontológicos do serviço dentário municipal de Ribeirão Preto, organizado por Augusta Aguiar em 1963, está depositado no Arquivo Público e Histórico de Ribeirão Preto, no Fundo Cel. Alfredo Condeixa Filho.
} 
Figura 9 - Página do Álbum Histórico e Fotográfico dos Postos Odontológicos do Serviço Dentário Municipal assistência realizada no Parque Infantil Amélia Junqueira

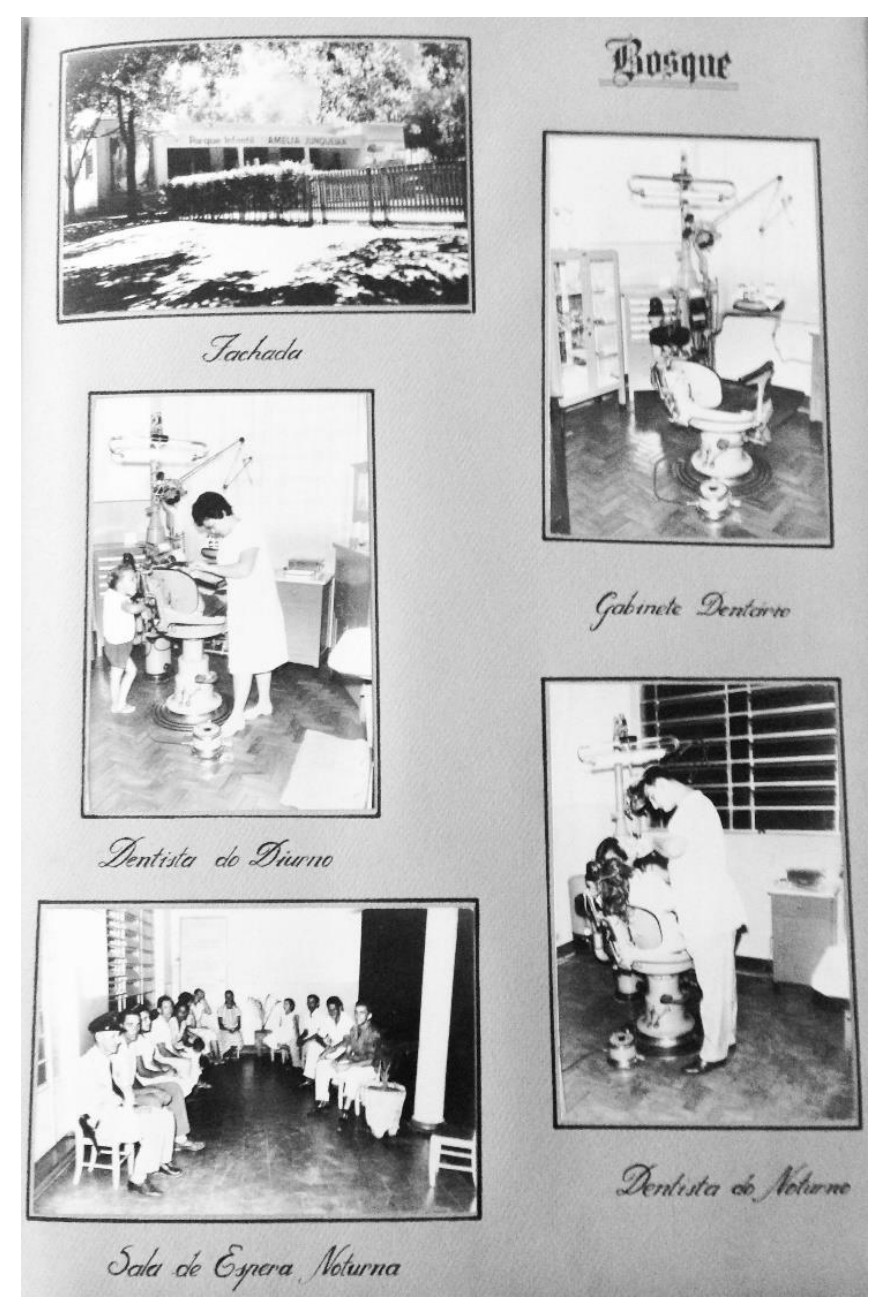

Fonte: AGUIAR $(1963)^{36}$

A primeira clínica odontológica diurna em parque infantil na cidade foi instalada em dezembro de 1951 no Parque Infantil Peixe Abbade, pelo prefeiro José de Magalhães, para atender as crianças do parque (figura 10). A clínica noturna foi criada sete anos depois, em fevereiro de 1958, pelo prefeito Costabile Romano, a fim de oferecer extração dentária em pessoas sem recursos. Em 1963, a clínica diurna estendeu seus serviços para as crianças matriculadas em diversas escolas municipais perto do local, e a clínica noturna continuava a efetuar apenas extrações dentárias. De 1951 a 1963 foram atendidas 12448 pessoas, sendo 4767 crianças.

${ }^{36} \mathrm{O}$ Álbum histórico e fotográfico dos postos odontológicos do serviço dentário municipal de Ribeirão Preto, organizado por Augusta Aguiar em 1963, está depositado no Arquivo Público e Histórico de Ribeirão Preto, no Fundo Cel. Alfredo Condeixa Filho. 
Figura 10 - Página do Álbum Histórico e Fotográfico dos Postos Odontológicos do Serviço Dentário Municipal - assistência realizada no Parque Infantil Peixe Abbade

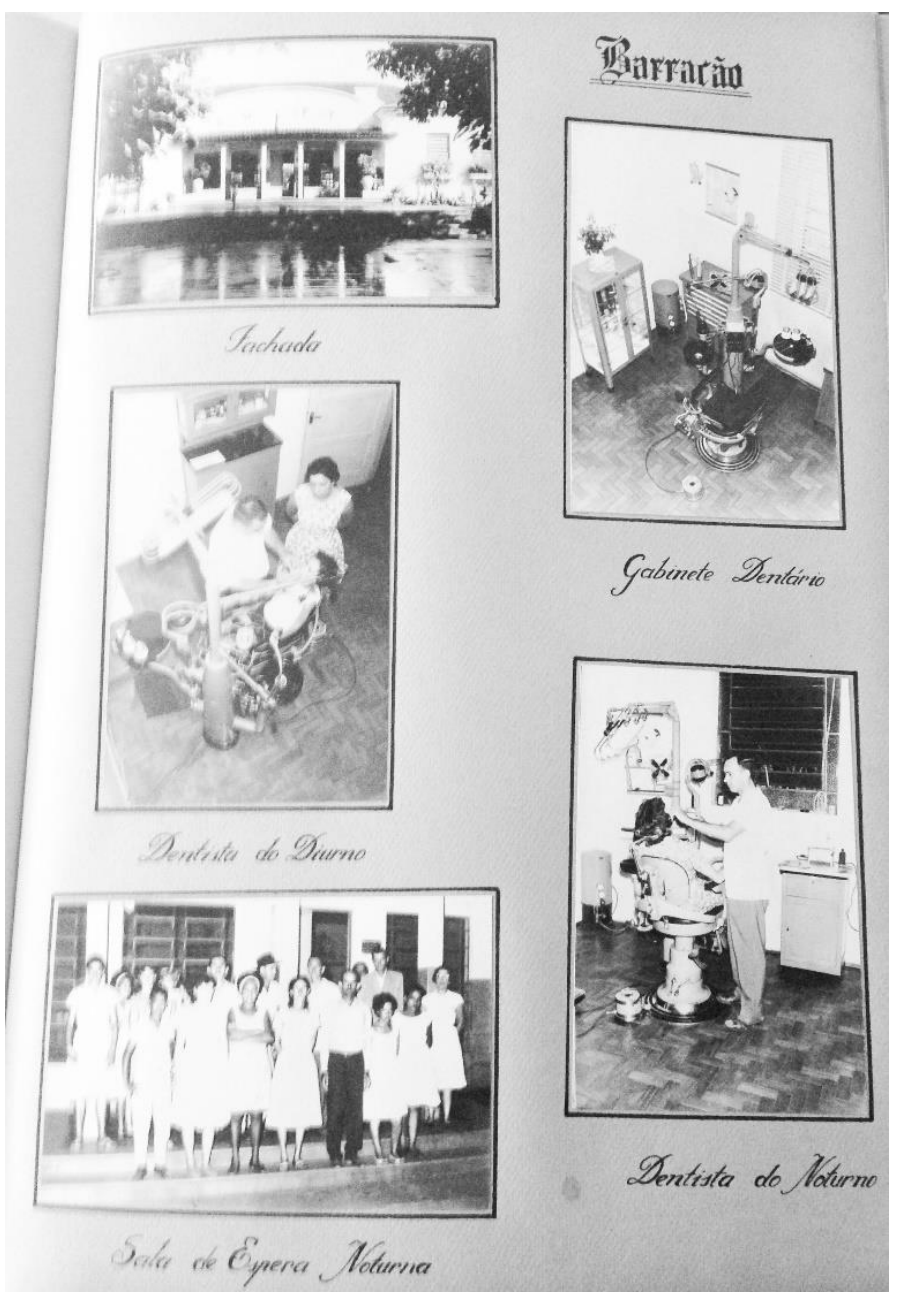

Fonte: AGUIAR $(1963)^{37}$

De acordo com Aguiar (1963), com a realização desses serviços realizados nos parques, não havia na cidade nenhuma pessoa reconhecidamente pobre que não tenha se beneficiado desta assistência, recebendo tratamento dentário completamente gratuito.

\subsubsection{Transporte}

Para viabilizar o braço assistencial dos parques, havia transporte, feito por um caminhão, para buscar e levar as crianças atendidas. Segundo o jornal A Tarde (1953, p. 6), era algo necessário para a educação daquelas crianças, pois “o transporte das crianças faveladas será

${ }^{37} \mathrm{O}$ Álbum histórico e fotográfico dos postos odontológicos do serviço dentário municipal de Ribeirão Preto, organizado por Augusta Aguiar em 1963, está depositado no Arquivo Público e Histórico de Ribeirão Preto no Fundo Cel. Alfredo Condeixa Filho. 
feito diariamente por meio de caminhões da prefeitura, passando elas o dia todo no aprazível logradouro. Sem dúvida de que se trata de medida digna de destaque, dado o caráter humanitário de que se reveste". (A TARDE, 1953, p. 6). As crianças faveladas citadas eram as crianças da favela conhecida como Tanquinho ${ }^{38}$ que frequentavam o Parque Infantil do Bosque.

Não faz muito tampo, noticiamos a providência que estava sendo estudada pelo prefeito Condeixa Filho, em favor das crianças da favela do Tanquinho e hoje podemos anunciar que essa providência será concretizada, no próximo mês de maio, data marcada para a inauguração do parque infantil recém construído pela prefeitura no bosque municipal, ao lado do local em que até pouco funcionou o 'playground'.

As crianças da favela do tanquinho frequentarão o Parque Infantil do Bosque, onde terão assistência médica e dentária, além de alimentação dietética tão necessária para tirá-los da subnutrição em que se encontram. (A TARDE, 1953, p. 6).

A figura 11 foi retirada do Álbum comemorativo do $1^{\circ}$ centenário da fundação da cidade do Ribeirão Preto e foi o único documento encontrado que divulgou fotografias sobre os transportes oferecidos às crianças dos parques. Nota-se que o transporte era realizado num caminhão improvisado.

Figura 11 - Transporte oferecido às crianças dos parques até 1958

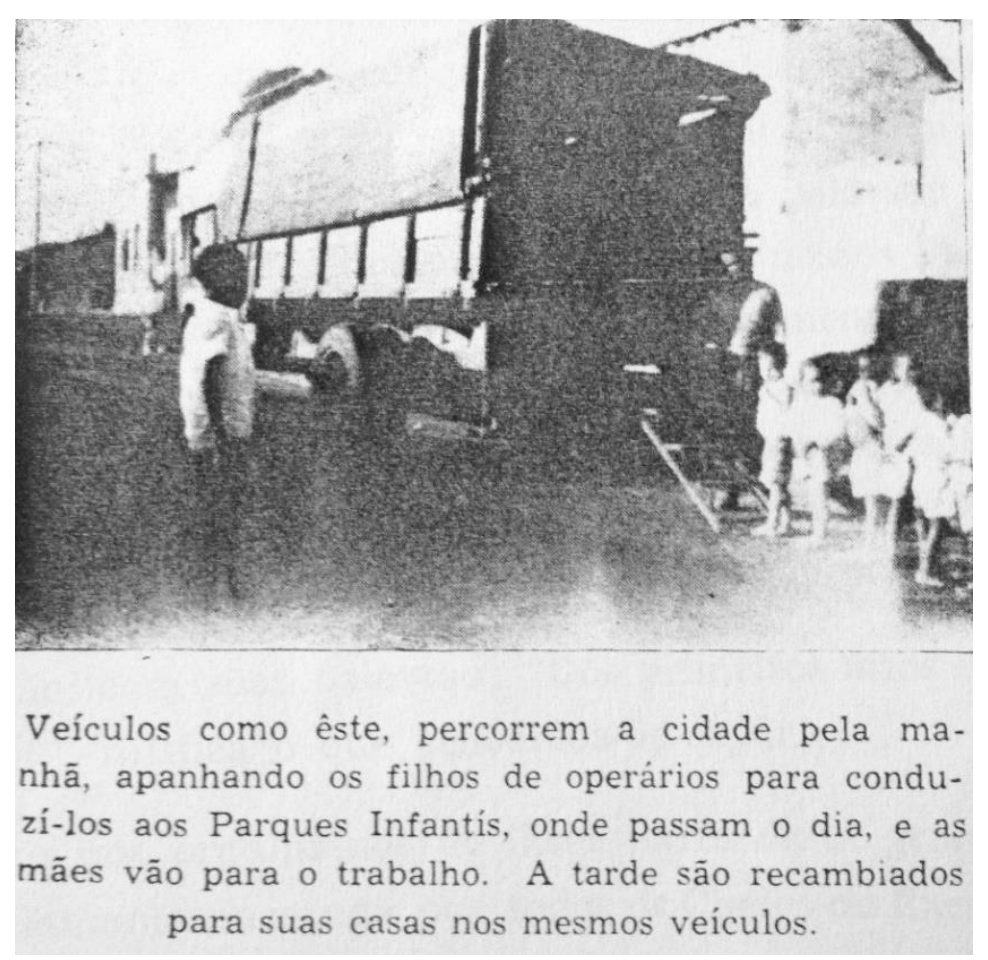

Fonte: COSTA $(1956)^{39}$

\footnotetext{
${ }^{38} \mathrm{O}$ Tanquinho é o que atualmente conhecemos como subsetor N-4 (Vila Carvalho).

${ }^{39} \mathrm{O}$ Álbum comemorativo do $1^{o}$ centenário da fundação da cidade do Ribeirão Preto, organizado por João Emboaba da Costa em 1956, está depositado no Arquivo Público e Histórico de Ribeirão Preto no Fundo Cel. Alfredo Condeixa Filho.
} 
De acordo com a Entrevistada 1 (FERREIRA, 2011), as crianças eram transportadas num caminhão adaptado: “eles adaptavam caminhão, nem sei como... acho que hoje num (sic) ia poder fazer isso... vinha um caminhão eles vinham tudo sentadinho (sic)... pegavam as crianças lá do Tanquinho”. A Entrevistada 3 conta que era muito difícil as professoras dos parques terem contato com os pais dos alunos: "quase num (sic) tinha porque trabalhavam o dia todo, né? Lá no bosque o caminhão que levava as crianças. Levava de manhã e voltava a (sic) tarde... alguns vinham a pé, né? Então quase num (sic) via!”.

Com a Lei n ${ }^{\circ}$ 721, de 27 de junho de 1958 (RIBEIRÃO PRETO, 1958a), o então prefeito Costabile Romano aperfeiçoou este serviço ao autorizar a aquisição de um ônibus para o transporte de estudantes dos Distritos de Ribeirão e para as crianças dos parques infantis. Em 1964, a Lei no 1431 (RIBEIRÃO PRETO, 1964a), promulgada pelo então prefeito Dr. Welson Gasparini, autoriza a compra de mais um ônibus e, em 1965, pela Lei no 1618 (RIBEIRÃO PRETO, 1965b), o prefeito Orestes Lopes de Camargo autoriza a compra de mais dois ônibus. Ou seja, de 1958 a 1965 totalizavam quatro ônibus para as crianças irem aos parques gratuitamente. De acordo com Daisy (DAHAREM, 2011, p. 98),

as crianças vinham de caminhão, era uma pobreza danada. Como eram pequenininhos, conforme a idade, lá eles tinham toda assistência, a enfermeira passava, cuidava, tomava banho pelas serventes, punha a roupa do parque... Só num (sic) deixava ir com a mesma roupa, porque no outro dia não voltava, então, eles tinham uma assistência assim, muito boa [...] As crianças que moravam no Campo Aberto, caminhão vinha busca (sic) todo dia e vinha trazê (sic). Então ou eles ficavam lá o dia todo, ou eles ficavam meio período lá e meio período na escola ${ }^{40}$.

\subsubsection{Alimentação}

As crianças também se alimentavam nos parques infantis, com um cardápio elaborado por especialistas no assunto, uma vez que a desnutrição infantil era um problema frequente e havia uma demanda a ser atendida:

a pedido do médico esteve neste parque orientando-nos de como deveria ser feita a alimentação das crianças, assim como deveriam ser feitos os lanches dados pelo parque à (sic) estas crianças, a eximia(sic) dietista da Faculdade de Medicina local dona Celia de Barros Del Galo. A sua visita surtiu proveitoso efeito, pois que conseguimos elevar o número de calorias para cada criança em cada lanche, de 800 para 1,600. (A TARDE, 1953, p. 15).

\footnotetext{
${ }^{40}$ De acordo com Daisy, atualmente o Campo Aberto são os bairros ao Norte do Ipiranga.
} 
A figura 12 expõe um momento em que as crianças do Parque Infantil Amélia Junqueira estão se alimentado, provavelmente na hora do almoço, pois nota-se que estão comendo arroz e feijão.

Figura 12 - Hora da alimentação no Parque Infantil Amélia Junqueira, setembro de 1961. Foto: Miyasaka

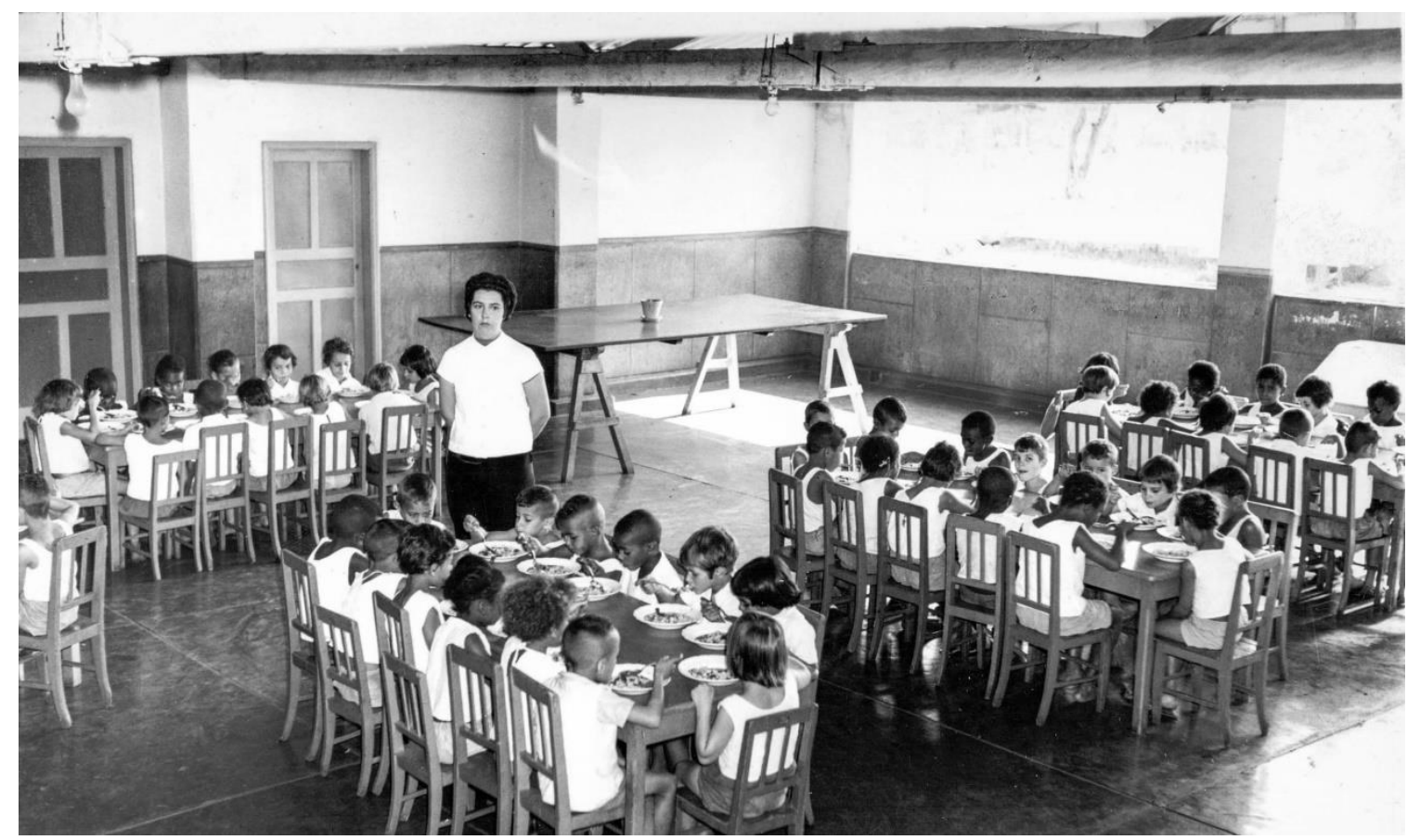

Fonte: Arquivo Público e Histórico de Ribeirão Preto $^{41}$

De acordo com Nilza (DARAHEM, 2011), ex-cozinheira do Parque Infantil Amélia Junqueira, era oferecido no parque: café da manhã, almoço, lanche da tarde e jantar. O café da manhã era pão, manteiga e leite e, sempre que possível, ela fazia bolo ou pudim. Relata que em dia de comemoração a hora da alimentação era sempre um piquenique no bosque. Conta também que houve situações em que as mães das crianças iam até ela para pedir receita das comidas que preparava no parque, pois em casa os filhos não comiam e na escola sim.

Seu Osvaldo (DARAHEM, 2011) foi funcionário do Parque Infantil Dona Iria Junqueira e conta que, nesse parque, uma vez por semana tinha macarronada com salsicha temperada (que fazia sucesso entre as crianças) e em outro dia mingau de fubá (que não agradava as crianças). Segundo Daisy (DARAHEM, 2011), nesse parque as crianças se alimentavam muito bem, principalmente porque a maioria dos alimentos eram provenientes da horta do próprio parque.

\footnotetext{
${ }^{41}$ A fotografia pode ser encontrada no Arquivo Público e Histórico de Ribeirão Preto, no fundo Cel. Alfredo Condeixa Filho, na Pasta 87, $n^{\circ}$ de registro 1082.
} 


\subsubsection{Doações e festejos}

Além da alimentação regular, as crianças recebiam várias doações, como bolas e brinquedos, principalmente na época dos festejos natalinos. Eram realizadas também quermesses, campanhas, festas, missas, cursos, apresentações culturais e esportivas, entre outros eventos com a presença de membros de diversas classes sociais para ajudar na infraestrutura e com donativos para materiais recreativos dos parques.

Hoje às 10 horas, no Parque Infantil do Bosque, com a presença do Sr. José Costa, Prefeito Municipal, autoridades, diretoria e professoras dos nossos parques infantis, pessoas matriculadas no 'Curso de Fundamentos e Recreação' e outros interessados, será realizada no Parque Infantil do Bosque uma reunião infantil, da qual participarão crianças também dos Parques da Vila Tibério e do Barracão. O programa previsto conterá variadas atividades infantis com as quais serão demonstradas muitas das técnicas utilizadas na recreação: A) Brinquedos cantados; B) Rodas dramatizadas; C) Dancinhas; D) Conteites; E) Jogos competitivos; F) Natação; G) Aulas historiadas; H) Declamação; Para as crianças haverá distribuição de refrigerantes. (A TARDE, 1955 , p. 6$)^{42}$.

A figura 13 retrata uma apresentação de crianças às autoridades no dia da inauguração do Parque Infantil Dona Iria Junqueira. Nota-se que há crianças de diferentes faixas etárias e grande multidão as admirando. $\mathrm{O}$ interessante é que, na ocasião, nenhuma criança estava descalça, todas estavam uniformizadas, com meias e sandálias, diferente do dia a dia delas no parque, como é possível notar no Catálogo das fotografias avulsas anexo a este trabalho.

\footnotetext{
${ }^{42}$ Não foi encontrado o significado de "Conteites". Entretanto, nota-se que era um tipo de atividade de recreação realizada nos parques.
} 
Figura 13 - Apresentação das crianças do Parque Infantil Dona Iria Junqueira na ocasião da inauguração do parque em 1959

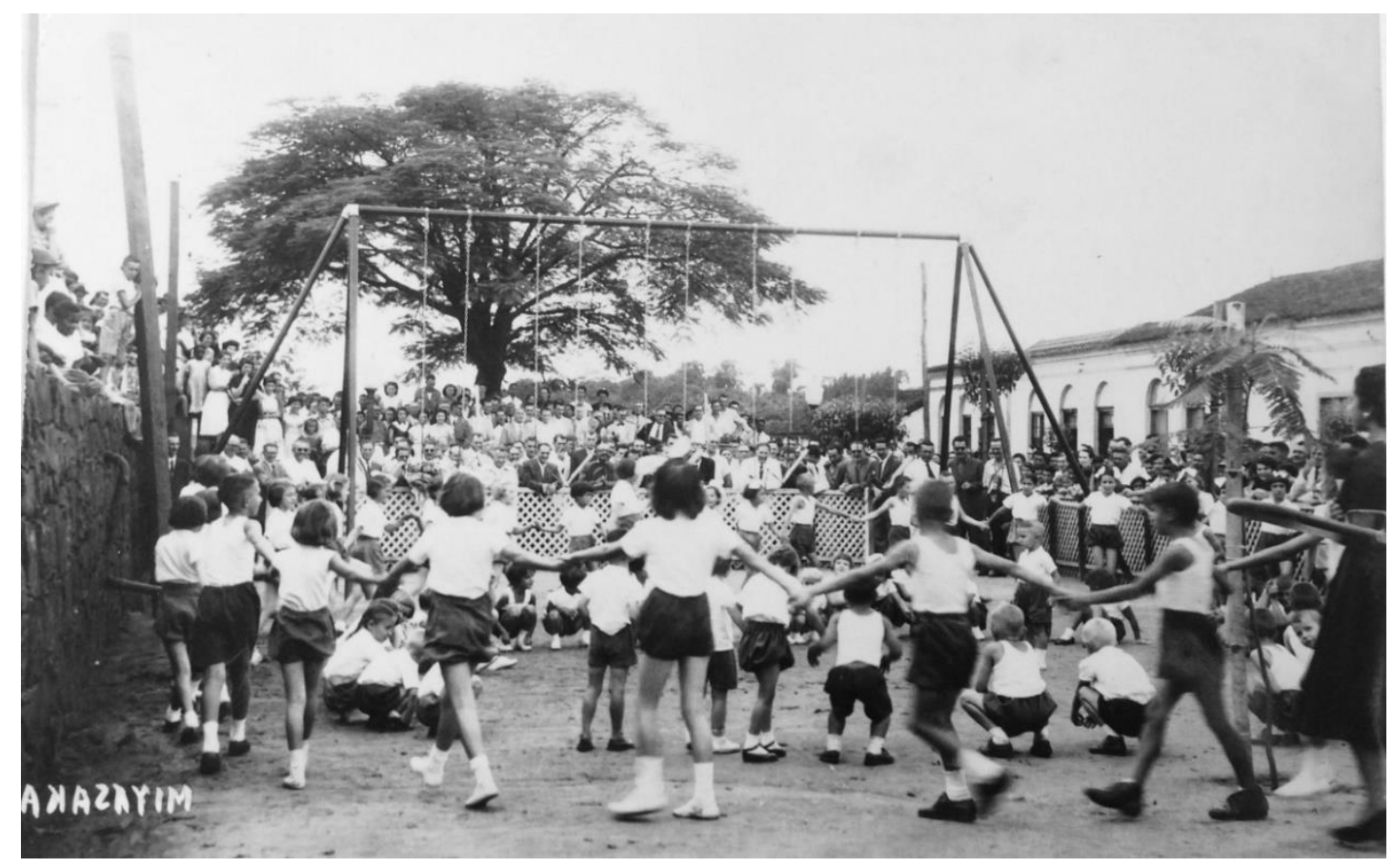

Fonte: Arquivo Público e Histórico de Ribeirão Preto ${ }^{43}$

As ex-professoras, Entrevistadas 1 e 3 (FERREIRA, 2011), relatam que as crianças que iam aos parques eram muito carentes e que, além da alimentação, disponibilizavam-se uniforme para as crianças. Segundo a Entrevistada 3:

Carentes, né? Muito carentes...haja vista que quase toda semana eu levava um ou outro pra passar o fim de semana comigo. Por que (sic) eles queriam morar comigo, né? Porque (sic)? A gente dava carinho, atenção...eu procurava sempre deixar minha clientela homogênea. Se os pais não podiam comprar o uniformezinho pra eles, eu comprava... se não podiam comprar o material, alguma coisa, eu comprava...pra um não fazer a discriminação, né? Que nossa... no parque, era a coisa mais interessante... as crianças vinham tão sujinhas!! A gente catava essas crianças, colocava.... porque tinha banheiro, né? Dava banho, dava uniforme, alimentação...eram crianças carentes, bem! Quando não, vinham com aquela... Porque tinha enfermeira e médico. Era uma assistência maravilhosa, viu? Nos parques... excelente. Tinham tudo! (FERREIRA, 2011).

Em 29 de janeiro de 1964 o jornal Diário da Manhã anunciou uma festa em que toda renda seria revertida aos parques infantis da cidade.

Os gráficos vão realizar uma grande festa em sua sede de campo, comemorando o Dia do Gráfico e levantando fundos para os parques infantis

\footnotetext{
${ }^{43}$ A fotografia pode ser encontrada em um Álbum do fundo Cel. Alfredo Condeixa Filho, no Arquivo Público e Histórico de Ribeirão Preto.
} 
de Ribeirão Preto. [...] Segundo estamos informados, os elementos responsáveis pelo acontecimento solicitarão ajuda de nosso comércio e indústria, levantando subsídios à concretização do que idealizaram, ou seja, solicitando a contribuição à festa, desde que todos os produtos lá vendidos no anunciado dia reverterão em benefício das criancinhas dos parques infantis. (DIÁRIO DA MANHÃ, 1964).

De acordo com a imprensa ribeirão-pretana do começo da década de 1960, os parques estavam passando por vários problemas e com isso muitas doações estavam sendo realizadas. Em 30 de janeiro de 1964, o jornal Diário da Manhã publicou que usineiros estavam atendendo aos apelos dos parques infantis.

O deputado federal Lino Morganti, tomando conhecimento da situação aflitiva em que se encontram os parques infantis da cidade, inclusive com o problema da paralização de fornecimento de alimentação às crianças, fez doação ao prefeito Dr. Welson Gasparini, de um caminhão carregado de gêneros alimentícios que lhe foi entregue pelo engenheiro J. Miocegne, gerente da Cia. Guatapará. O chefe do Executivo, agradeceu sensibilizado o oferecimento.

O Dr. Luiz Ribeiro Pinto, por sua vez, ao saber da situação em que se encontram os parques infantis, ofereceu à prefeitura dez sacos de açúcar, colaborado assim, para amenizar o grave problema de abastecimento aos parques infantis. (DIÁRIO DA MANHÃ, 1964).

Logo após o carnaval daquele ano, em 16 de fevereiro, o jornal Diário da Manhã publicou que nos dias 22 e 23 haveria dois espetáculos do "Palestra Patin Show" na Cava do Bosque, com $50 \%$ da renda em benefício dos parques infantis da cidade. Em 26 de fevereiro o veículo publicou que no dia seguinte haveria também uma noitada de arte musical em prol do parque infantil, promovida pelo Departamento de Educação e Cultura.

Em 10 de novembro do mesmo ano, pela Lei n 1474 (RIBEIRÃO PRETO, 1974b), o então prefeito Dr. Welson Gasparini autorizou a gravação do Hino de Ribeirão Preto e no art. $2^{\circ}$ ordenou que a renda auferida fosse destinada aos parques infantis da municipalidade, ou seja, em todas as vezes que o disco fosse reproduzido por emissoras de rádio os parques infantis da cidade estariam se beneficiando.

A sociedade civil também organizava campanhas para arrecadação de donativos para os parques: em março de 1953 repercutiu na imprensa local uma campanha pró-parque infantil, que recolheu 140 latas de Vic-Maltema do SESI, 140 latas de leite condensado de senhoras da sociedade ribeirão-pretana e também cr\$ 712,00 de uma campanha dos calouros da Faculdade de Farmácia e Odontologia da cidade, que transformou o tradicional "trote" em coletor para as crianças.

Magnífica iniciativa dos veteranos da Faculdade de Farmácia e Odontologia, contando com a boa vontade dos 'calouros'. O tradicional trote dirigido pelo 
Centro Acadêmico 'Carneiro Leão', neste ano, teve alta finalidade. Está sendo feita a coleta de donativos para as crianças subnutridas do Parque Infantil do Barracão e para os flagelados nordestinos. (A TARDE, 1953).

Em 17 de março de 1953 um leitor escreveu para o jornal A Tarde se dizendo contra a campanha pró-parque infantil, pois era dever da prefeitura da cidade dar todo amparo ao parque e que não deveria o particular fazer uma obra que é de alçada governamental. A resposta do jornal A Tarde foi a seguinte:

\section{INICIATIVA PARTICULAR}

Se não fosse a iniciativa particular, em nosso país, a assistência à infância seria um mito. Não fosse a boa vontade, a colaboração ampla do particular e não teríamos realizado essa maravilha que aí está e que é a 'Campanha da Redenção da Criança', através de 1.000 Postos de Puericultura já instalados no país.

O QUE É O PARQUE INFANTIL

Não adianta mostrar, por palavras, o que é o Parque Infantil do Barracão. É preciso visitáa-lo. Dantes, aquela praça era um matagal espesso. Meninos sujos, embarreados ou poeirentos, jogavam futebol de pé de meia, ou viviam às turras. Um dia a Prefeitura construiu o Parque e depois a praça. Ajardinouse o local aprazível.

\section{CENTENAS DE CRIANÇAS}

Matriculou centenas de crianças, arranjou professoras do Estado, médicos e dentistas da Prefeitura; fez análises, exame médico completo abreugrafia e encontrou um quadro contristador: TRACOMA 45\%; OPILAÇÃO 72\%; SUB NUTRIÇÃO 64\%; e acrescidos ainda de pré-tuberculosos - 11\%; péssima dentição $28 \%$, além de outras moléstias.

PRIMEIROS CUIDADOS

Quem manusear o relato bem feito pelo Dr. Dante Guazelli, diretor do Departamento de Assistência Social e de Alimentação, da Prefeitura, que auxiliado pelos médicos do Serviço de Pronto Socorro, lerá coisas incríveis. Em Janeiro de 1952 - há um ano - era deplorável o estado de 400 crianças. Foram recuperadas no Parque Infantil. Neste ano as matrículas subiram a 700. O primeiro cuidado foi o de nutri-las com frutas e alimentá-las com sopas. Foram mobilizadas as pessoas de boa vontade e surgiram os beneméritos do Parque Infantil. Por quê? Simplesmente porque até HOJE, não foi criado, oficialmente o Parque Infantil do Barracão.

\section{UM GRANDE DONATIVO}

Na manhã de hoje, um possante carro, cor marrom, parou em frente à redação de A TARDE e senhoras de nossa sociedade trouxeram outro donativo valioso - 140 latas de leito condensado que haviam coletado entre pessoas bondosas. Tudo para o Parque Infantil.

\section{OS ESTUDANTES}

Os acadêmicos da Faculdade da Faculdade de Farmácia e Odontologia acorreram ao nosso apelo. Ontem nos entregaram 712 cruzeiros. A coleta continuará. No Parque Infantil estão 700 crianças necessitando de assistência. Quem se negará dá-la? Quem? Está ali, pertinho e fácil de se comprovar o que afirmamos. Em Ribeirão Preto, terra linda, de arranha-céus e palácios, de 
calçamento perfeito, praças bonitas e 16 bancos, há muita criança à espera de melhor assistência. Quem se negará a auxiliá-las? (A TARDE, 1953). ${ }^{44}$

\subsubsection{Olimpíadas parqueanas e campeonatos de futebol}

Outros eventos que mobilizavam os parques infantis eram as olimpíadas e campeonatos de futebol entre os parques da cidade. Na maioria das vezes o Parque Infantil Peixe Abbade ganhava, a ponto de permanecer sem derrotas durante 26 partidas. "Com a vitória de domingo último o parque infantil totalizou a $26^{a}$ partida sem conhecer o amargo de uma derrota". (A TARDE, 1953, p. 20).

De acordo com Daisy (DARAHEM, 2011), geralmente os campeonatos de futebol ocorriam no Parque Infantil Peixe Abbade, porque o campo de futebol lá era o maior dos parques da cidade.

Esses campeonatos de futebol eram largamente difundidos pela imprensa local, tanto que apenas em 1955, no jornal A Tarde, foram divulgadas 10 notícias sobre o futebol do Parque Infantil do Barracão:

- 13/01/1953 - Empatou o Parque Infantil;

- 23/02/1953 - Vitorioso o Parque Infantil;

- 23/06/1953 - Parque Infantil goleou;

- 27/06/1953 - Parque Infantil visitará domingo o Distrito de Gaturamo (Bonfim Paulista);

- 30/06/1953 - Permanece invicto o Parque Infantil;

- 05/10/1953 - Vitória do Parque Infantil;

- 21/10/1953 - Vitória do Parque em Jardinópolis;

- 28/10/1953 - Parque Infantil 1 x 0 Cajuru: 26 partidas invictas;

- 24/11/1953 - Parque Infantil F. C. - comunicado;

- 01/12/1953 - Derrotado o Parque Infantil: coube ao Palmeiras quebrar a invencibilidade do time, orientado por Uberaba.

Nota-se que o time de futebol das crianças do Parque Infantil Peixe Abbade, àquela época chamado de Parque Infantil do Barracão, era reconhecido como um time de futebol juvenil profissional, sendo nomeado de Parque Infantil F. C. Percebe-se ainda que o jornal A

\footnotetext{
${ }^{44}$ Vale lembrar que o Parque Infantil Peixe Abbade foi o primeiro Parque Infantil de Ribeirão Preto, inaugurado em 1951, mas que legalmente foi criado apenas um ano e quatro meses depois, em 20 de abril de 1953, pela Lei nº 292 (RIBEIRÃO PRETO, 1953a).
} 
Tarde era também um meio de comunicação entre a direção de tal parque com as crianças que jogavam por ele.

A direção de futebol do Parque Infantil do Barracão, por nosso intermédio comunica aos seus jogadores que, em vista de ter sido adiada a primeira rodada do campeonato da $2^{\mathrm{a}}$. divisão de profissionais fica também adiada a sua excursão a cidade de Franca, onde o Parque Infantil F. C. jogaria com o Juvenil do Palmeiras F. C. fazendo a preliminar do jogo Botafogo F. C. x Palmeiras F. C.

\subsection{Distribuição territorial dos parques infantis de Ribeirão Preto}

Em 1956, Ribeirão Preto comemorou o centenário da cidade e em meio às festividades foi organizado por João Emboaba da Costa um Álbum comemorativo do $1^{o}$ centenário da fundação da cidade do Ribeirão Preto ${ }^{45}$. Nesse Álbum, os parques infantis eram tidos como instituições que contribuíam com a civilidade de Ribeirão Preto, devido à combinação que realizavam entre o papel escolar e o assistencial.

Se nos perguntassem o que representam os parques infantis e qual a sua finalidade, estaremos plenamente aptos para satisfazer essa indagação curiosa. Sim, porque estando com eles desde seu primeiro vagido, desde o seu desabrochar para nobre finalidade a que se destinam, somos testemunhas vivas do quanto significam para o progresso de uma cidade que nasceu para ser grande como é o caso de Ribeirão Preto. (SOUZA, M., 1956, p. 83).

À vista disso, os parques de Ribeirão Preto se tornaram vitrine das administrações municipais, caracterizavam-se e diferenciavam-se pelo seu caráter escolar assistencialista. Consequentemente, até o final da década de 1970 foram criados em Ribeirão Preto quatorze parques infantis (Quadro 1).

\footnotetext{
${ }^{45}$ Há um exemplar do Álbum comemorativo do $1^{\circ}$ centenário da fundação da cidade do Ribeirão Preto no Arquivo Público e Histórico da cidade.
} 
Quadro 1 - Inauguração dos parques infantis de Ribeirão Preto

\begin{tabular}{|c|l|c|}
\hline $\begin{array}{c}\text { Ordem de } \\
\text { inauguração }\end{array}$ & \multicolumn{1}{|c|}{ Nome } & $\begin{array}{c}\text { Data da } \\
\text { inauguração }\end{array}$ \\
\hline 1 & Parque Infantil Peixe Abbade & $08 / 12 / 1951$ \\
\hline 2 & Parque Infantil Amélia Junqueira & $12 / 05 / 1953$ \\
\hline 3 & Parque Infantil Anita Procópio Junqueira & $08 / 12 / 1954$ \\
\hline 4 & Parque Infantil Dona Iria Junqueira & 1954 \\
\hline 5 & Parque Infantil de Dumont & 1956 \\
\hline 6 & Parque Infantil de Guatapará & 1956 \\
\hline 7 & Parque Infantil Santa Maria Goretti & $05 / 01 / 1959$ \\
\hline 8 & Parque Infantil dos Bandeirantes & $12 / 05 / 1963$ \\
\hline 9 & Parque Infantil Ana dos Santos Gabarra & $03 / 08 / 1965$ \\
\hline 10 & Parque Infantil Padre Emilio Jarbinet & $28 / 05 / 1967$ \\
\hline 11 & Parque Infantil Prof. Áurea A. Braghetto Machado & $07 / 04 / 1970$ \\
\hline 12 & Parque Infantil Euclides Castilhano & $21 / 10 / 1975$ \\
\hline 13 & Parque Infantil José Pedro Moreira & $05 / 01 / 1977$ \\
\hline 14 & Parque Infantil dos Campos Elíseos & x \\
\hline
\end{tabular}

Fonte: produção do próprio autor

Em 2008, Andrea Coelho Lastória ${ }^{46}$ organizou o Atlas Escolar Histórico, Geográfico e

Ambiental de Ribeirão Preto, que contém um tema sobre os bairros da cidade. Nesse tema ela elaborou um mapa com os subsetores municipais ${ }^{47}$. Esse mapa, apesar de ser uma representação atual e não reproduzir a cidade de Ribeirão Preto nas décadas de 1950 a $1970^{48}$, foi editado 49 para este trabalho e pode-se, por conseguinte, compreender a localização dos parques infantis (figura 14) e, com base no quadro 2, localizá-los nos subsetores dessa última figura.

\footnotetext{
${ }^{46}$ Professora Doutora no Departamento de Educação, Informação e Documentação da Faculdade de Filosofia, Ciências e Letras de Ribeirão Preto da Universidade de São Paulo. Coordena o grupo de pesquisa "Estudo da Localidade de Ribeirão Preto - ELO". Membro diretor do Fórum Iberoamericano de Educação, Geografia e Sociedade - Geoforo. Membro representante do campus da USP de Ribeirão Preto na Comissão Municipal de Geografia e Estatística - portaria do IBGE / Censo 2010.

47 "Na cidade de Ribeirão Preto, não é possível localizar o limite entre alguns bairros. A Prefeitura Municipal de Ribeirão Preto criou, em janeiro de 1987, uma lei que estabelece uma divisão territorial mais precisa, chamada subsetor. Um subsetor pode conter vários bairros e seu limite é definido pelos cursos d'água e pelas principais avenidas da cidade". (LASTÓRIA, 2008, p. 72).

${ }^{48}$ Não foi encontrado um mapa de Ribeirão Preto das décadas de 1950 a 1970 que pudesse ajudar na compreensão da espacialidade dos parques da cidade naquele momento. Contudo, de acordo com o XXX volume da Enciclopédia dos Municípios Brasileiros, verbete Ribeirão Preto (IBGE, 1958, p. 36), na década de 50 havia em Ribeirão Preto "bairros residenciais e industriais, denominados Alto da Cidade, Barracão, República; Campos Elíseos, Bosque e Vila Tibério, este último constituindo, por si só, uma verdadeira cidade”.

${ }^{49}$ Os círculos representam que existiu apenas um parque infantil naquele subsetor, e o quadrado simula que três parques ficavam localizados naquele subsetor.
} 


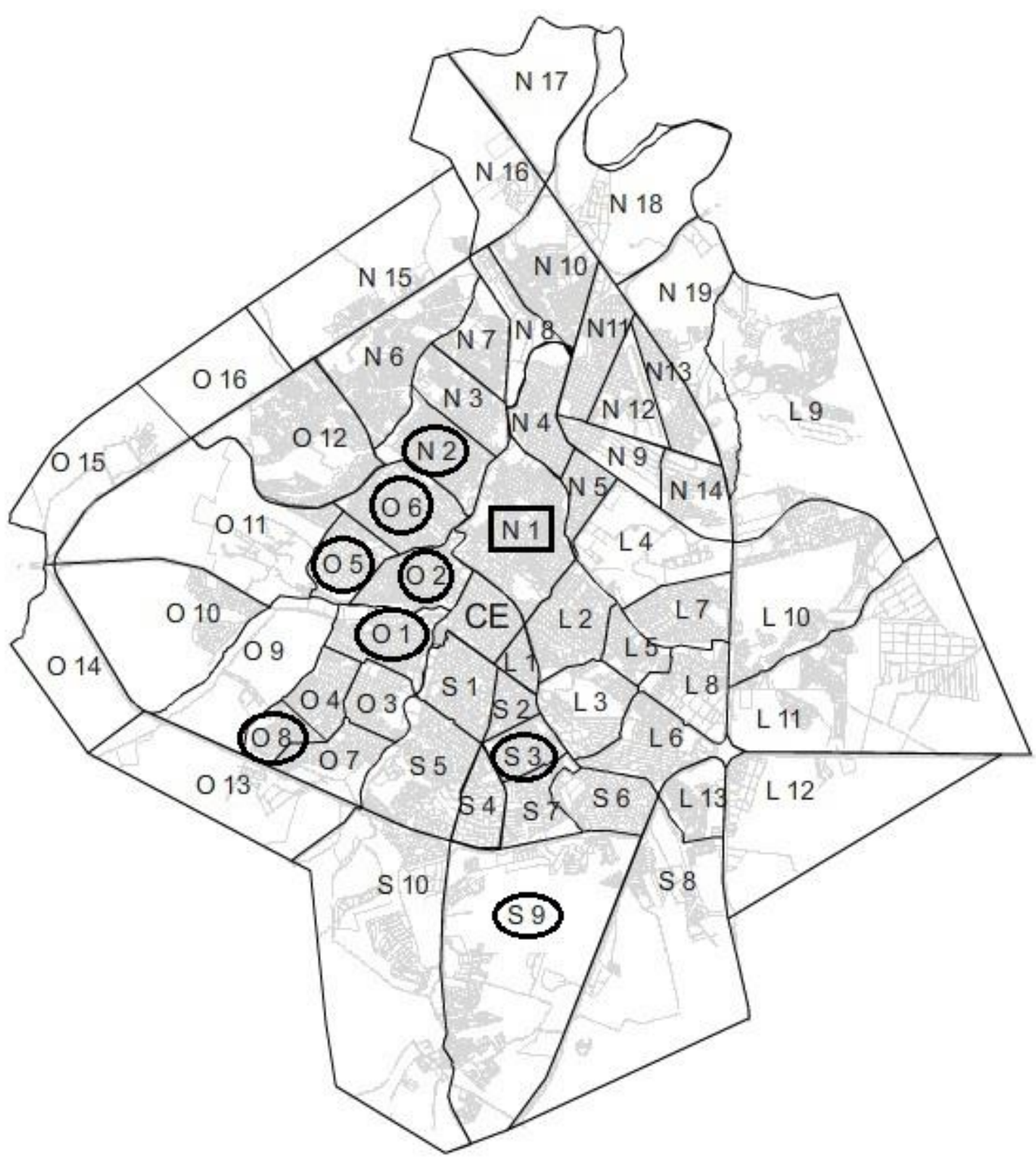

Fonte: LASTÓRIA $(2008)^{50}$

\footnotetext{
${ }^{50} \mathrm{O}$ mapa está dividido pelo bairro mais conhecido de cada Subsetor de Ribeirão Preto, conforme a lista a seguir: CE - Centro ; N1 - Campos Elíseos; N2 - Vila Albertina; N3 - Jardim Presidente Dutra; N4 - Vila Carvalho; N5 - Jardim Independência; N6 - Jardim Heitor Rigon; N7 - Antônio Marincek; N8 - Adelino Simioni; N9 - Vila Elisa; N10- Quintino Facci II; N11 - Quintino Facci I; N12 - Jardim Planalto; N13 - Jardim Salgado Filho; N14 - Jardim Jockey Club; N15 - Galo Bravo; N16 - Distrito empresarial; N17 - N17; N18 Recra de Campo; N19 - Parque dos Servidores; S1 - Boulevard; S2 - Jardim São Luiz; S3 - Jardim Irajá; S4 Jardim Canadá; S5 - Alto da Boa Vista; S6 - City Ribeirão; S7 - Jardim Botânico; S8 - Recreio das Acácias; S9 - Bonfim Paulista; S10 - Royal Park; L1 - Vila Seixas; L2 - Jardim Paulista; L3 - Iguatemi; L4 - Educandário; L5 - Jardim Castelo Branco; L6 - Ribeirânia; L7 - Palmares; L8 - Lagoinha; L9 - Jardim Florestan Fernandes; L10 - Candido Portinari;L11 - Jardim Juliana; L12 - Recreio Anhanguera; L13 - Jardim Manoel Pena; O1 Vila Virginia; O2 - Vila Tibério; O3 - Parque Ribeirão Preto; O4 - Jardim Morumbi; O5 - Monte Alegre; O6 Ipiranga; O7 - Jardim Marchesi; O8 - Jardim Maria da Graça; O9 - Fazenda Experimental; O10 - Jardim Recreio; O11 - USP; O12 - Planalto Verde; O13 - Quinta da Boa Vista; O14 - O14; O15 - O15; O16 - O16. (LASTÓRIA, 2008).
} 
Quadro 2 - Localização dos parques infantis de Ribeirão Preto

\begin{tabular}{|l|l|l|}
\hline \multicolumn{1}{|c|}{ Nome } & \multicolumn{1}{|c|}{$\begin{array}{c}\text { Nome do bairro no } \\
\text { período da } \\
\text { inauguração }\end{array}$} & \multicolumn{1}{|c|}{$\begin{array}{c}\text { Bairro/Subsetor } \\
\text { atual }\end{array}$} \\
\hline Parque Infantil Peixe Abbade & Barracão & Ipiranga/O-6 \\
\hline Parque Infantil Amélia Junqueira & Campos Elíseos & Campos Elíseos/N-1 \\
\hline Parque Infantil Anita Procópio Junqueira & Vila Tibério & Vila Tibério/O-2 \\
\hline Parque Infantil Dona Iria Junqueira & Bonfim Paulista & Bonfim Paulista/S-9 \\
\hline Parque Infantil de Dumont & Dumont (Distrito) & Dumont-SP \\
\hline Parque Infantil de Guatapará & Guatapará (Distrito) & Guatapará-SP \\
\hline Parque Infantil Santa Maria Goretti & Vila Virgínia & Vila Virgínia/O-1 \\
\hline Parque Infantil dos Bandeirantes & Vila Recreio & Vila Recreio/N-2 \\
\hline Parque Infantil Ana dos Santos Gabarra & Santa Cruz do Jacques & Jardim Irajá/S-3 \\
\hline Parque Infantil Padre Emîlio Jarbinet & Lapa & Vila Lapa/N-1 \\
\hline Parque Infantil Prof. Áurea A. Braghetto Machado & Vila Lobato & Jardim Antártica/O-5 \\
\hline Parque Infantil Euclides Castilhano & Guatapará (Distrito) & Guatapará-SP \\
\hline Parque Infantil José Pedro Moreira & Vila Fraternidade & Parque Ribeirão/0-8 \\
\hline Parque Infantil dos Campos Elíseos & Campos Elíseos & Campos Elíseos/N-1 \\
\hline
\end{tabular}

Fonte: produção do próprio autor

Ao analisar a figura 14, percebe-se, com exceção dos parques Iria Junqueira (S-9), Ana dos Santos Gabarra (S-3) e José Pedro Moreira (O-8), respectivamente em Bonfim Paulista, Santa Cruz do José Jacques ${ }^{51}$ e Vila Fraternidade, que os outros oito parques estão relativamente próximos e não há parques instalados no centro (CE) da cidade. Pode-se conferir que eles foram instalados em bairros “operários", periféricos e com população menos abastada, ressaltando o parque infantil como recurso assistencialista das administrações municipais da cidade.

Nota-se também que, por ser um mapa de 2008, não aparecem os dois parques infantis situados em Guatapará e o Parque Infantil de Dumont, pois já não eram mais distritos da cidade. O município de Dumont está localizado a 18 km de Ribeirão Preto e Guatapará fica a 62 km da cidade da qual fora distrito (figura 15). Por não serem mais responsabilidade de Ribeirão, por terem outra administração e por estarem distantes, a documentação sobre os parques localizados nessas duas cidades é escassa e, dessa maneira, excepcionalmente há poucas informações sobre eles.

\footnotetext{
${ }^{51}$ O bairro de Santa Cruz do José Jacques é o que atualmente conhecemos como subsetor S-3 (Jardim Irajá).
} 


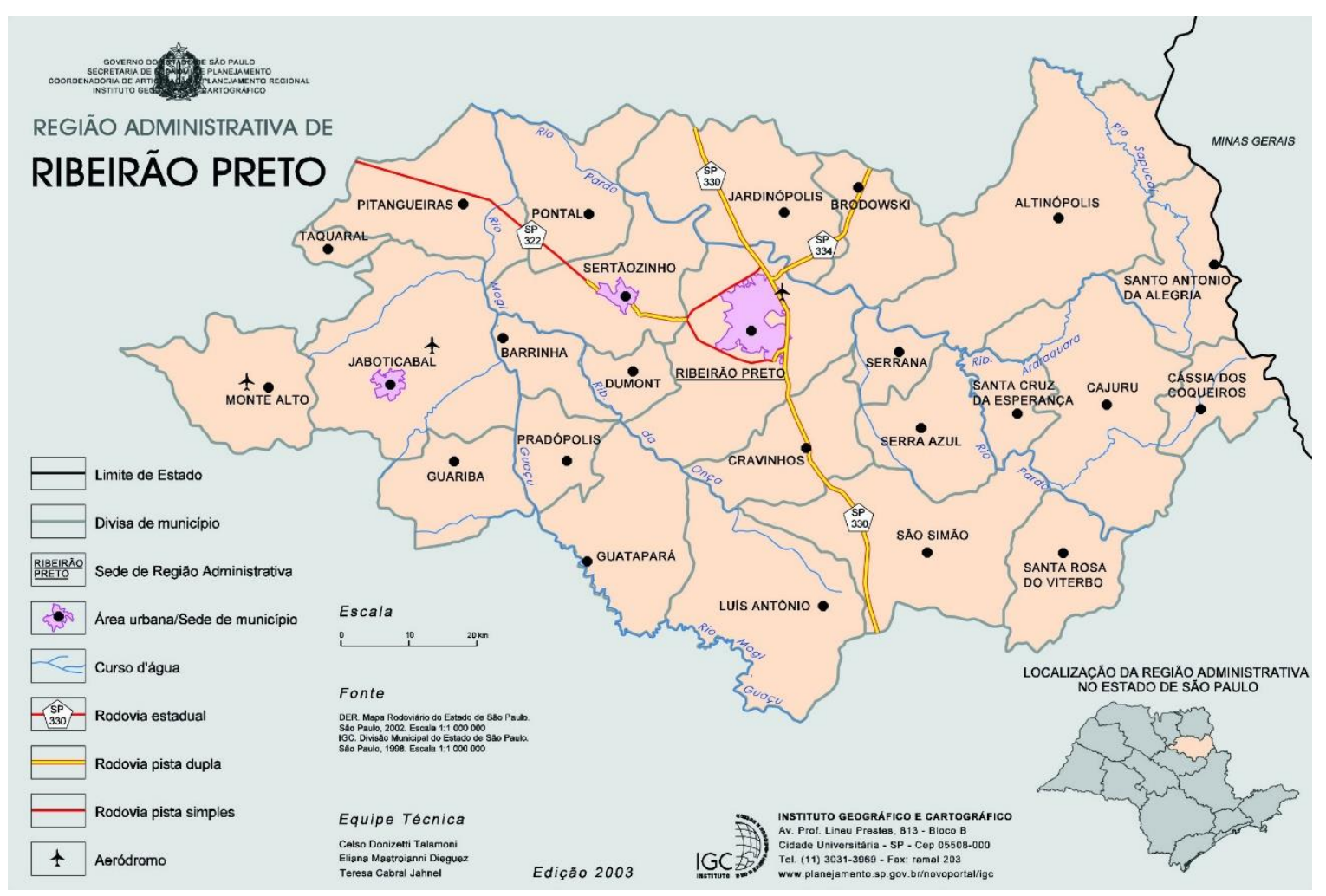

Fonte: DER (2002)

Todavia, sobre os outros parques há um valioso acervo documental no Arquivo Público e Histórico de Ribeirão Preto, mostra de que as administrações municipais queriam estabelecer uma boa imagem pública dos parques infantis da cidade, o que pode ser comprovado pelo Álbum comemorativo do $1^{o}$ centenário da fundação da cidade do Ribeirão Preto, bem como pelos documentos fotográficos da época, por matérias/notas divulgadas pela imprensa sobre as atividades que eram oferecidas nos parques às crianças e os benefícios que ocasionavam à sociedade, como também as celebrações e festejos desses parques, tais como as olimpíadas, jogos e desfiles.

Não pensem os menos avisados que os parques infantis sejam fornalhas onde ardem os ensinamentos de cultura geral, para enriquecer o intelecto das crianças, cravando-lhe a semente basilar para os grandes conhecimentos futuros. Isto não, porque este papel compete aos Grupos Escolares! Aos parques infantis cabe preparar o desenvolvimento físico e mental das crianças através de recreações apropriadas, cuidando, também, do lado cívico, através de comemorações das principais datas da nossa História. Por outro lado, o convívio das crianças desde a mais tenra idade, com outros meninos, proporciona-lhe grande desembaraço social, tornando mais firme a sua atenção, elucidando a sua capacidade viso-motora, imprimindo maior confiança no seu autodomínio, proporcionando-lhe esclarecida iniciativa 
própria e, por tudo, fecundado a sua inteligência embrionária. (SOUZA, M., 1956, p. 83).

Essas realizações públicas, convertidas agora em documentos depositados no Arquivo Público e Histórico de Ribeirão Preto, são peças da produção de uma imagem pública dos parques infantis e contam sobre seu lugar no aparelho escolar da cidade, participando ainda dos fins políticos do governo local, que àquela altura tinha como representante o prefeito Costabile Romano. Os vários aspectos antes apontados, o caráter escolar e assistencial, a associação do parque e dos serviços de saúde, o transporte, a alimentação e os eventos representam ações públicas a partir das quais a imagem igualmente pública dos parques infantis foi sendo apresentada à sociedade. A produção considerável de fotografias, a repercussão das atividades dos parques nos jornais locais, publicações como os álbuns comemorativos e, bastante importante, o destaque atribuído aos parques nas comemorações do centenário de Ribeirão Preto são indicativos de que havia o intento de projetá-los, de tornar conhecido o papel que cumpriam.

\subsection{Os parques infantis de Ribeirão Preto de 1951 a 1963}

Foram resgatadas fotografias de apenas sete parques infantis da cidade: Parque Infantil Peixe Abbade; Parque Infantil Amélia Junqueira; Parque Infantil Anita Procópio Junqueira; Parque Infantil Dona Iria Junqueira; Parque Infantil de Dumont; Parque Infantil Santa Maria Goretti; e Parque Infantil dos Bandeirantes. Com exceção do parque do Distrito de Guatapará, que data 1956 e pouco se sabe sobre ele, os parques citados foram todos fundados de 1951 a 1963.

\subsubsection{Parque Infantil Peixe Abbade}

Localização: Av. Dom Pedro I, no 196 - Ipiranga (Praça Antônio Prado).

O Parque Infantil Peixe Abbade foi o primeiro parque implantado em Ribeirão Preto. No começo era chamado de Parque Infantil de Ribeirão Preto, pois era o único do município. Após a inauguração do segundo parque infantil na cidade, passou a ser popularmente chamado de Parque Infantil da Praça Antônio Prado, Parque Infantil do Ipiranga ou Parque Infantil do Barracão. 
Esse parque foi implantado na cidade, pois no final dos anos 40 e início dos anos 50, a população ribeirão-pretana, por meio da imprensa, clamava por postos de puericultura e por ambientes cujo foco fosse os menores.

Nas comemorações Independência do Brasil, em 07 de setembro de 1950, o prefeito José de Magalhães lançou a pedra fundamental do Parque Infantil de Ribeirão Preto, de acordo com o jornal A Cidade, de 22 de agosto de 1950.

Esse parque infantil será construído na Praça 'Antônio Prado', sita defronte à Estação do Barracão.

É a primeira vez na história do município que algo de realmente importante vai ser feito para o povo do Barracão, que até hoje vive em ruas sem calçamento e desconhecendo uma série de conforto desfrutado por elementos de outros bairros da cidade.

De fato, o Barracão de Cima esteve sempre ao abandono. Agora, com a atitude do Dr. José Magalhães, determinando ali a construção de um parque infantil, aquela grande coletividade, constituída de operários, sem dúvida estará satisfeita. Seus filhos terão onde brincar e praticar esportes. (A CIDADE, 1950).

A inauguração ocorreu no dia 08 de dezembro de 1951, pelo prefeito José de Magalhães, com capacidade para acolher 400 crianças. Em janeiro de 1952, com a entrada do novo prefeito, Cel. Alfredo Condeixa Filho, o Departamento de Cultura de Ribeirão Preto, por meio de Plínio Travessos dos Santos, enviou ao novo prefeito o relatório ${ }^{52}$ do Departamento referente ao ano anterior, já fazendo alguns esclarecimentos e apontamentos sobre os serviços realizados pelo departamento, entre eles o de parques infantis e recreação.

\section{PARQUE INFANTIL}

32 - Sem a menor intervenção e conhecimento deste Departamento, foi escolhido o local, confeccionada a planta, lançada a 'pedra fundamental' e instalado o Parque Infantil do Barracão, cuja inauguração leve lugar no dia 08 de dezembro, apesar de não ter sido estruturado em lei, pelo que seu funcionamento está sendo feito irregularmente, se bem que prestando ótimos serviços, graças à dedicação do seu corpo docente.

33 - Naturalmente, por falta de aludida lei, o corpo docente, arbitrariamente constituído, possui apenas 5 professoras, sendo 2 estaduais, comissionadas, e 3 municipais, nomeadas estas para escolas municipais cujo funcionamento está suspenso, que são:

- D. Wanda Carneiro Sobral, estadual, que se habilitou em estágio completo em parque infantil;

- D. Carmem Carolina Bastos Ferraz, estadual, de Educação Física, também com estágio de habilitação em parque infantil;

- D. Nair Alves Ferreira, municipal, de Recreação, idem;

- D. Cléa Silva Carvalho, municipal, de Educação Infantil, idem; e

- D. Marília Teresinha Narciso, municipal, Auxiliar de Recreação, idem.

\footnotetext{
${ }^{52} \mathrm{O}$ documento pode ser encontrado no Arquivo Público e Histórico de Ribeirão Preto, no fundo Educação, na caixa $30, \mathrm{n}^{\circ}$ de registro 666 , ano 1952.
} 
34 - Para o serviço de vigilância, limpeza e outros conta o Parque com o seguinte pessoal:

- D. Maria Nunes Morganti, Servente (zeladora);

- D. Brígida dos Santos Menenguetti, Servente;

- Osvaldo Pinto Ferraz, Servente; e

- Manual Amancio, Servente.

35 - Com esse diminuto pessoal, principalmente do corpo docente, funciona o parque em dois períodos diários - das 8 às 11 e das 14 às 17 - quando o natural será seu funcionamento em períodos de 4 horas, tendo para cada um corpo docente especial, pois, como é evidente, muito fatigantes são os trabalhos reclamados das professoras, obrigadas que são a initerrupta atividade. Além disso, indispensável é, pelo menos, uma professora substituta, capaz, para substituir qualquer professora quando faltar.

36 - O parque é de capacidade para 400 crianças - 200 em cada período, já com esse número preenchido, mas nem todas podendo frequentá-lo, visto não possuírem o uniforme exigido. Tratando-se de instituição que deve ser destinada, principalmente, às crianças mais necessitadas, indispensável será o fornecimento de uniformes pelo próprio parque àquelas cujos pais não possam adquirir. (SANTOS, 1952, grifo nosso).

De acordo com Plínio Travassos dos Santos, apesar da Lei nº 97 (RIBEIRÃO PRETO, 1949), de 01 de julho de 1949, colocar o serviço de parques infantis e recreação como parte do Departamento de Cultura do município, o prefeito José de Magalhães não recorreu a este departamento para instalar o parque na cidade, oficialmente criado somente em 20 de abril de 1953 pelo prefeito Cel. Alfredo Condeixa Filho, por meio da Lei n 292 (RIBEIRÃO PRETO, 1953a).

Em 10 de maio de 1952, o jornal A Tarde noticiou que A Gazeta de São Paulo havia publicado uma reportagem sobre o Parque Infantil do Barracão. Tal reportagem exaltava o parque, explicava como ele era e também o que era oferecido nele:

Quem conheceu a praça Antônio Prado em frente à Estação do Barracão, no bairro do mesmo nome, há dois anos, retornando ali hoje não acredita tratar do mesmo local de outrora. O amplo terreno, esburacado pelas chuvas e salpicado de mato, de aspecto campestre e desolador, que ironicamente ostentava título de praça, adquiriu novas feições.

No centro da grande área, ergue-se agora um majestoso edifício, de linhas modernas, cercado de jardins magnificamente tratados, recortados de alamedas pavimentadas. E, à sua frente, cintila ao sol a água de uma piscina em azulejos. E, como corolário disso tudo, o alarido alegre de crianças em bando que brincam no 'playground' na piscina, nos campos de voleibol e basquetebol. Na fachada do prédio, lê-se: 'Parque infantil'.

AMPARO À CRIANÇA POBRE

A primeira vista, aquilo parece mais uma escola, apenas com a diferença de ser uma escola modelo, em que as crianças dispõem de diversões múltiplas. Mas a gente do Barracão e suas cercanias sabe melhor o que significa aquela casa. As crianças do bairro, cuja população é essencialmente operária, viviam uma vida difícil, como seus pais por causa delas. Lugar afastado do centro, sem calçamento, muitas vezes sem água. Recanto ermo, cheio de mato, um pó terrível na seca e uma lama infernal nas águas os pais operários viam-se 
obrigados a deixar os filhos crescerem ao Deus dará. Quando chegava na idade escolar, havia grupo perto. Mas enquanto não chegava, a criançada tinha mesmo que andar solta pela terra e pelos campos, exposta a tudo quanto é perigo. Porque, naturalmente, numa família operária, todos os maiores trabalham e não há quem tome conta das crianças.

Afinal, a Prefeitura Municipal, sobre a gestão do ex-prefeito Dr. José de Magalhães, resolveu entrar no terreno da assistência social. O município, que progride a passos de gigante precisa de novas gerações mais sadias e mais produtivas. E para consegui-lo, e mister em parar a infância. Raciocínio velho, problema milhares de vezes focalizado e ventilado, admira que não tenham os municípios providenciado antes essa solução tão simples e urgente. Ribeirão Preto, através daquele seu prefeito, resolveu pôr mãos à obra, e fê-lo com capricho.

\section{O QUE É O PARQUE INFANTIL}

Construído especialmente para esse fim o Parque Infantil do Barracão constitui verdadeiramente, uma instituição modelar, desde a sua simples estrutura, as dimensões e disposições de suas salas, até o aparelhamento e equipamento especializado para os esportes infantis.

Nas quadras amplas, a criançada aprende, na prática de vôlei, basquete e outros jogos, a prática salutar do esporte. É, nesse terreno, a magnífica piscina, construída em azulejo, cuja água se renova permanentemente, recebendo regularmente tratamento adequado à sua higienização.

$\mathrm{Na}$ parte posterior do seu terreno, o parque possui seu playground, com os mais variados tipos de diversões, desde a tradicional gangorra e o escorregador que destrói fundos de calças, até o moderno passo de gigante e os balanços de sólidas armações metálicas. E em meio a isso tudo, sob a vista de professores dedicados, as crianças do Barracão, inclusive dos Campos Elíseos, entre 3 e 13 anos, vão aprendendo a viver e praticar o indiscutível axioma latino 'mens sana in corpore sano'.

\section{ASSISTÊNCIA MÉDICO-DENTÁRIA}

Como não podia deixar de ser, o parque infantil exerce rigorosa assistência médico-dentária para os seus alunos, que hoje sobe a cifra de 520. Seus gabinetes médico e dentário, dotados de sóbrios, porém, modernos aparelhamentos, atendem uma média de 30 crianças por dia, cada um. E muitas vezes as crianças saem do consultório médico com receita e remédio, pois não faltam ali as amostras farmacêuticas para distribuição gratuita.

TRABALHO, HIGIENE, EDUCAÇÃO SOCIAL

A direção do parque infantil dedica especial cuidado à orientação educacional de seus alunos. Nas mãos de competentes professores, as crianças operárias recebem uma educação social de grande alcance, enquanto que se iniciam na prática de trabalhos manuais ou no aprendizado rudimentar de música e educação cívica.

E constitui também um dos pontos básicos do programa educacional do parque a educação alimentar e sanitária das crianças. Ali se lhes fornecem sopas e lanches preparados sob controle dietético, ensinando-se-lhes o valor da boa alimentação. E, de outra parte, os amplos e bem instalados banheiros favorecem a formação de salutares hábitos higiênicos.

UMA OBRA DE GRANDE ALCANCE

Como frisamos no início desta reportagem, a criação dos parques infantis constitui uma obra de mensurável alcance. Trata-se verdadeiramente, de um valioso trabalho de preparação de gerações mais sadias e produtivas, capazes de um progresso ainda mais rápido e sólido que temos empreendido até agora. E, embora constitua um encargo não leve para os municípios, estes sem dúvida auferirão desse empreendimento os maiores benefícios. Assim o compreendeu o ex-prefeito Dr. José de Magalhães e assim o compreende o atual prefeito 
ribeirão-pretano ano Condeixa Filho, que vem continuando e ampliando a obra do seu antecessor, em benefício das classes trabalhadoras e de toda coletividade. (A TARDE, 1952).

A denominação "Peixe Abbade" foi promulgada pelo prefeito José Costa, em 05 de julho de 1955, pela Lei n 443 (RIBEIRÃO PRETO, 1955c). Quatro dias depois, o jornal A Tarde publicou o agradecimento da família de Peixe Abbade pela homenagem que fizeram ao advogado e jornalista que havia falecido há pouco tempo.

No Arquivo Público e Histórico de Ribeirão Preto há dois álbuns (figuras 16 e 17), do fundo Cel. Alfredo Condeixa Filho, que não têm títulos, mas que apresentam um pouco do parque em ocasiões especiais: a figura 17 apresenta inclusive o time de atletismo das crianças do Parque Infantil do Barracão em atividade.

Figura 16 - Álbum 2 - Parque Infantil da Praça Antônio Prado em 10 de maio de 1953

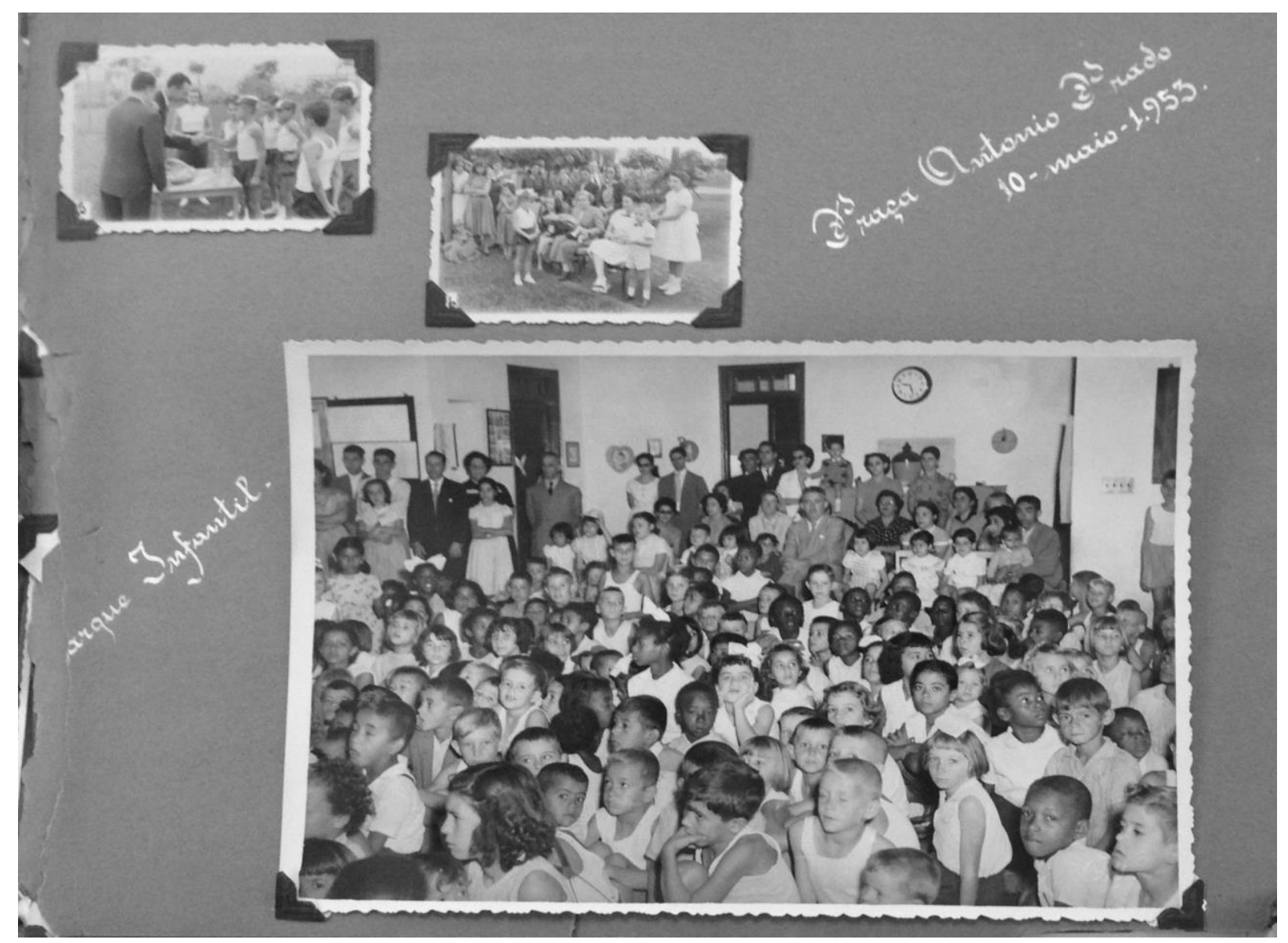

Fonte: Arquivo Público e Histórico de Ribeirão Preto ${ }^{53}$

\footnotetext{
${ }^{53}$ O Álbum pode ser encontrado no Arquivo Público e Histórico de Ribeirão Preto, no fundo Cel. Alfredo Condeixa Filho.
} 


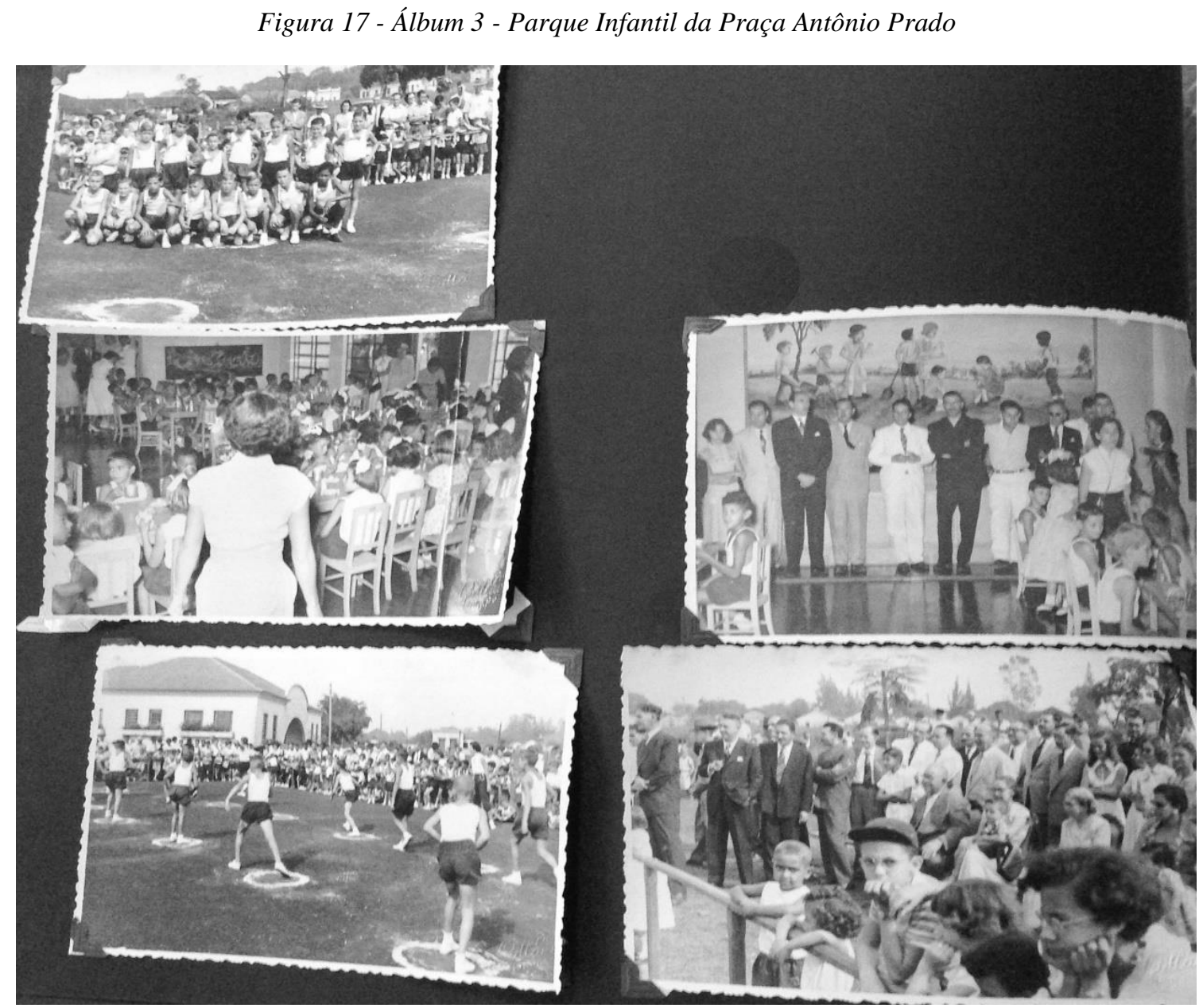

Fonte: Arquivo Público e Histórico de Ribeirão Preto ${ }^{54}$

Pelas figuras 18 e 19, pode-se observar a fachada do prédio do parque, que lembra um pouco a arquitetura de Victor Dubugras, considerado um precursor do modernismo ou protomoderno, principalmente na estação de Mairinque. Já as figuras 20 e 21 apresentam o interior do parque: a figura 20 mostra as crianças pequenas durante uma aula de musicalização infantil, tocando alguns instrumentos musicais (triângulo, pandeiro, tambor e chocalho). Já a figura 21 exibe as crianças sentadas junto a mesas do salão de refeições do parque, em grupos de quatro, recebendo de professoras e funcionário um prato de sopa. E a figura 22 mostra crianças ao redor de uma mesa de pingue-pongue, acompanhando o jogo entre quatro crianças. Ao lado da mesa está um homem afrodescendente, possivelmente o professor de educação física.

\footnotetext{
${ }^{54} \mathrm{O}$ Álbum pode ser encontrado no Arquivo Público e Histórico de Ribeirão Preto, no fundo Cel. Alfredo Condeixa Filho.
} 
Figura 18 - Parque Infantil Peixe Abbade

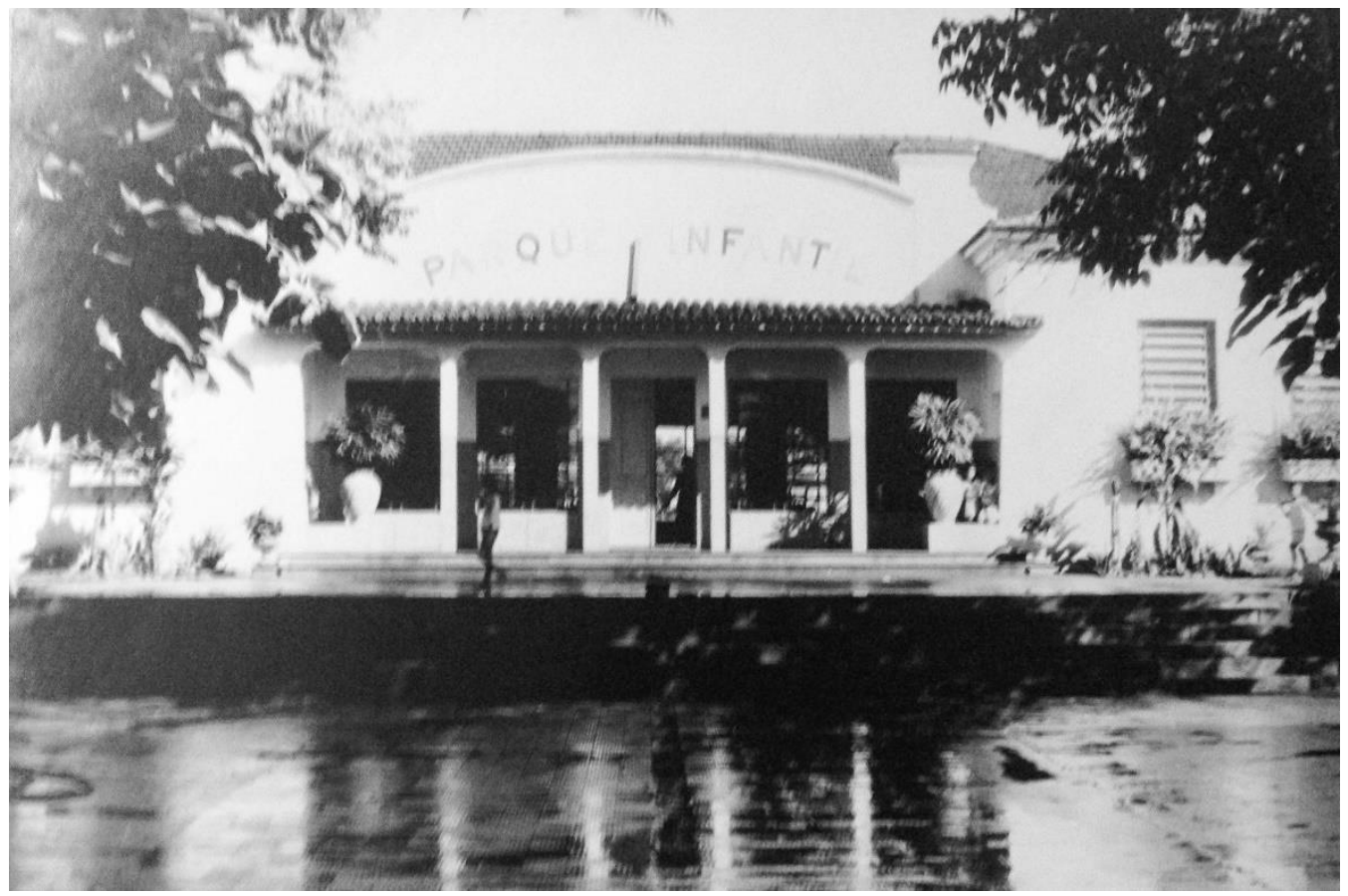

Fonte: AGUIAR $(1963)^{55}$

Figura 19 - Parque Infantil Peixe Abbade, setembro de 1961. Foto: Miyasaka

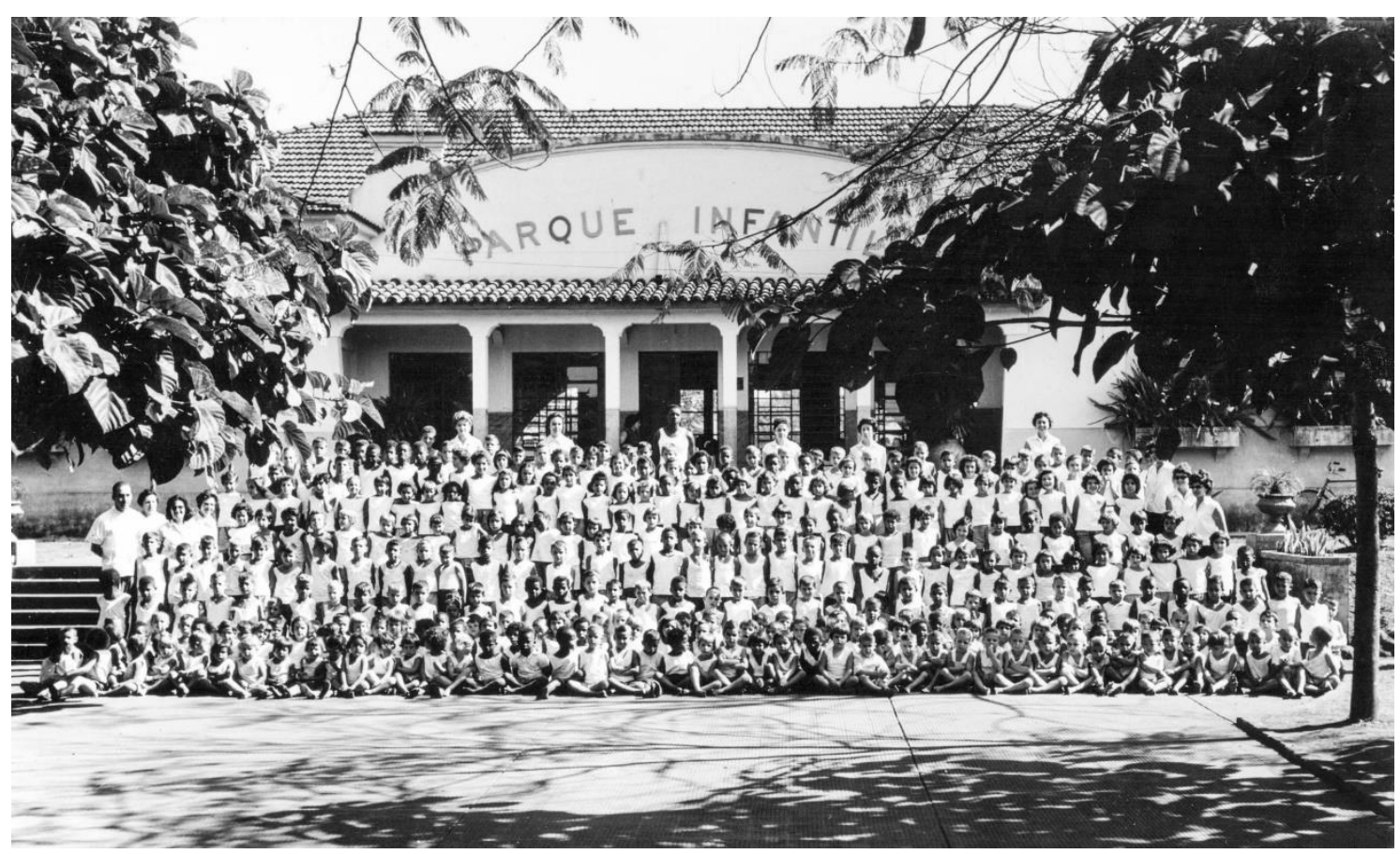

Fonte: Arquivo Público e Histórico de Ribeirão Preto ${ }^{56}$

\footnotetext{
${ }^{55}$ Fotografia retirada do Álbum histórico e fotográfico dos postos odontológicos do serviço dentário municipal de Ribeirão Preto, organizado por Augusta Aguiar em 1963, depositado no Arquivo Público e Histórico de Ribeirão Preto, no Fundo Cel. Alfredo Condeixa Filho.

${ }^{56}$ A fotografia pode ser encontrada no Arquivo Público e Histórico de Ribeirão Preto, no fundo Cel. Alfredo Condeixa Filho, na Pasta 87, $\mathrm{n}^{\circ}$ de registro 1061.
} 
Figura 20 - Parque Infantil Peixe Abbade, setembro de 1961. Foto: Miyasaka

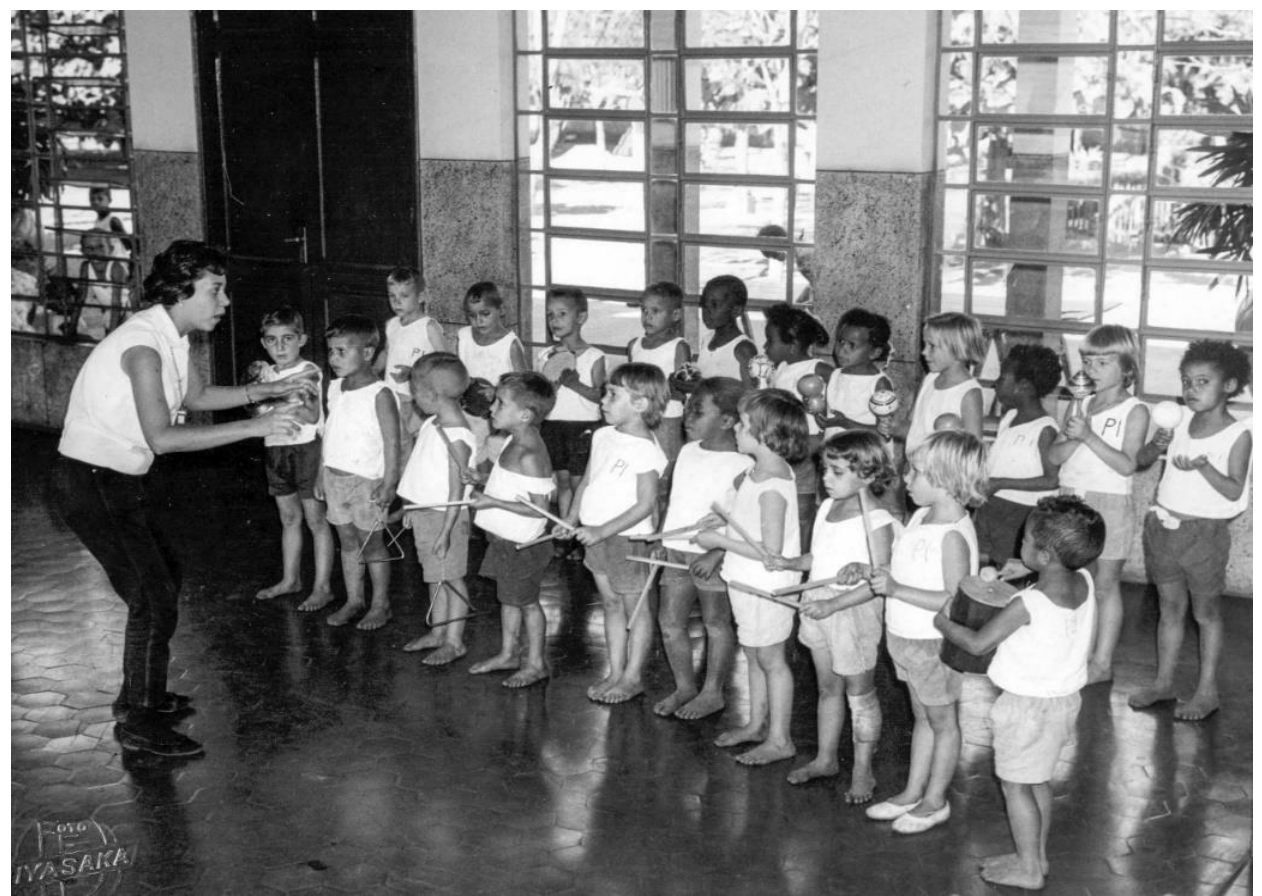

Fonte: Arquivo Público e Histórico de Ribeirão Preto 57

Figura 21 - Parque Infantil Peixe Abbade, setembro de 1961. Foto: Miyasaka

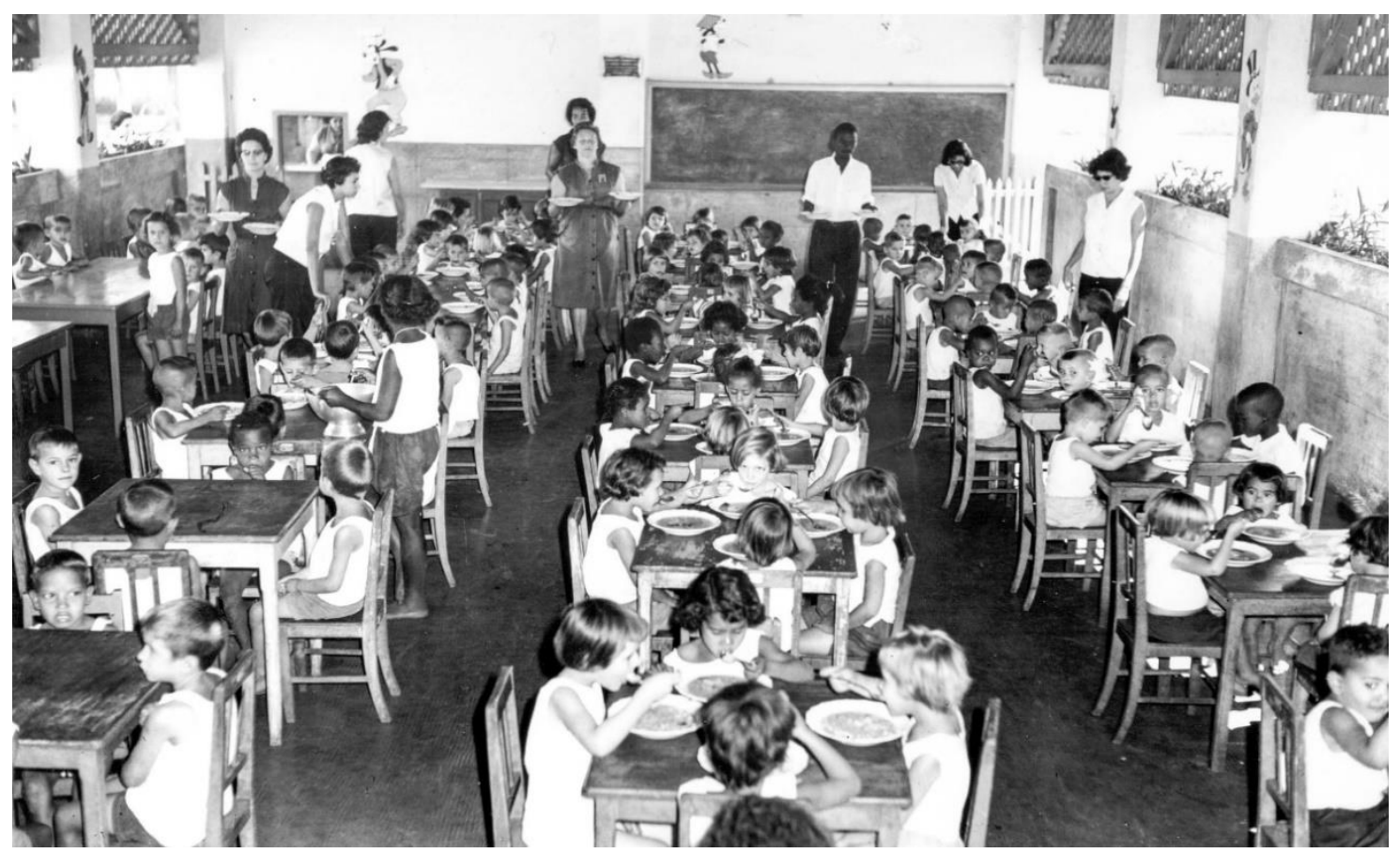

Fonte: Arquivo Público e Histórico de Ribeirão Preto ${ }^{58}$

\footnotetext{
${ }^{57}$ A fotografia pode ser encontrada no Arquivo Público e Histórico de Ribeirão Preto, no fundo JPM, na Pasta $66, \mathrm{n}^{\circ}$ de registro 731 .

${ }^{58}$ A fotografia pode ser encontrada no Arquivo Público e Histórico de Ribeirão Preto, no fundo no fundo Cel. Alfredo Condeixa Filho, na Pasta 87, nº de registro 1062.
} 
Figura 22 - Parque Infantil Peixe Abbade, setembro de 1961. Foto: Miyasaka

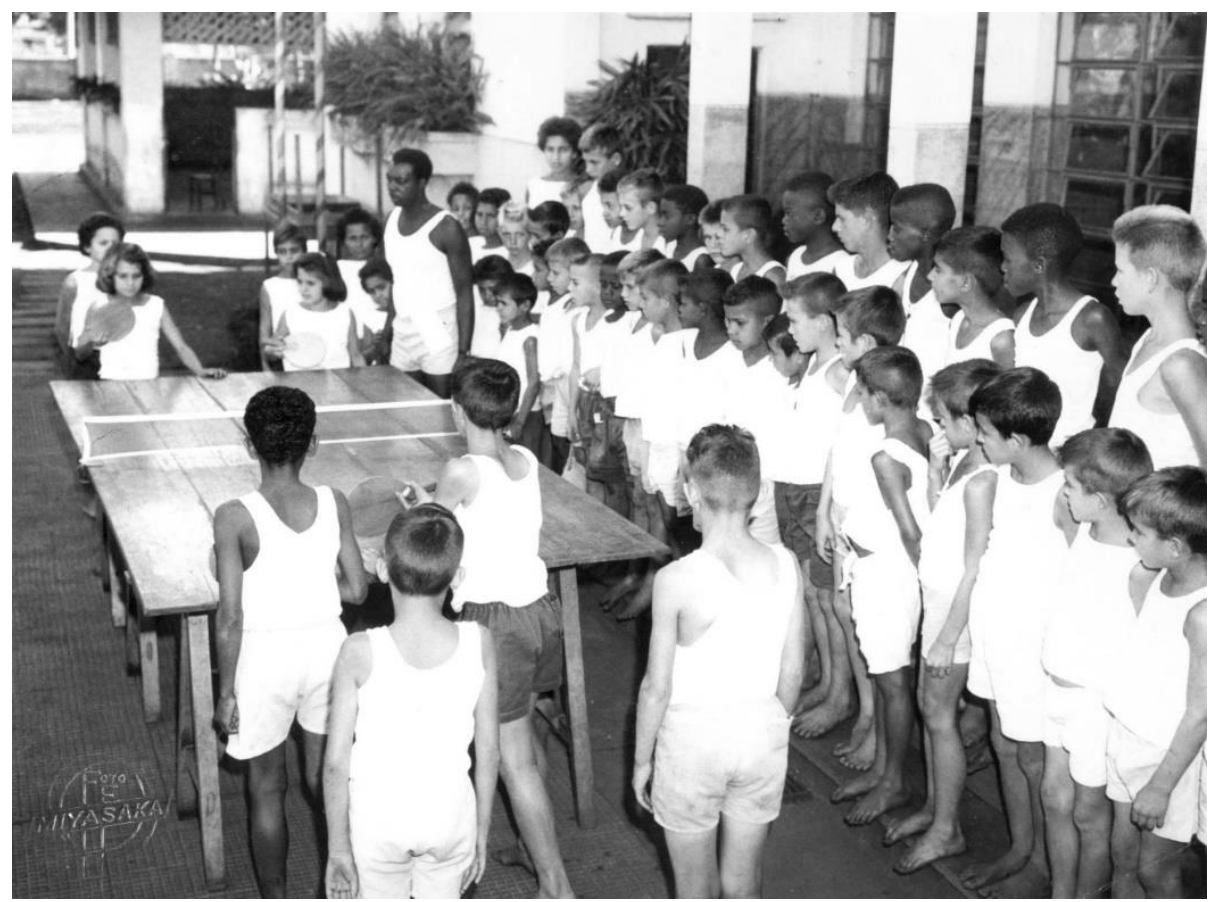

Fonte: Arquivo Público e Histórico de Ribeirão Preto ${ }^{59}$

Como foi o primeiro parque infantil da cidade, o Peixe Abbade era o parque mais propagandeado pela imprensa local e também o mais fotografado, uma vez que constam 19 fotos desse parque entre as 66 fotos avulsas depositadas no arquivo público da cidade. Era ainda o parque que recebia o maior número de doações realizadas pela sociedade ribeirão-pretana, de acordo com as inúmeras reportagens publicadas pela imprensa da cidade.

Era um parque bem grande e que recebia em média 400 crianças por dia. Segundo o jornal A Tarde, de 10 de abril de 1959, foram fornecidas 12345 refeições às crianças no mês de março. Além disso, 162 tratamentos dentários, 172 consultas médicas, 197 exames médicos, 587 curativos e 167 cortes de cabelo foram realizados. No mês seguinte, em 07 de maio, o jornal A Tarde publicou que esses números haviam aumentado no mês de abril, com exceção dos exames médicos e cortes de cabelo que diminuíram: 18035 refeições foram fornecidas, 288 tratamentos dentários, 186 consultas médicas, 92 exames médicos, 646 curativos e 129 cortes de cabelo foram realizados. Nesse mesmo mês, o parque ofereceu às suas crianças e também às crianças dos outros parques, serviços de otorrinolaringologia com o Dr. Alberto Blucher, totalizando 257 atendimentos.

\footnotetext{
${ }^{59}$ A fotografia pode ser encontrada no Arquivo Público e Histórico de Ribeirão Preto, no fundo no fundo Cel. Alfredo Condeixa Filho, na Pasta 87, nº de registro 1063.
} 
Em 10 de abril de 1966, de acordo com o jornal Diário da Manhã, o prefeito Dr. Welson Gasparini inaugurou oficialmente, no Parque Infantil Peixe Abbade, uma Escola Vocacional Parqueana: um novo núcleo educacional instituído pelo Dr. Alfeu Gasparini, diretor do Departamento de Educação e Cultura da cidade. Nessa nova escola o regime de estudo era de tempo integral e as aulas eram divididas em fases, incluindo-se no currículo normal práticas educativas de enfermagem, datilografia, noções elementares de eletricidade, pintura em tecido, arte culinária, horticultura, canto, música, línguas, visitas aos museus, às fabricas, às escolas e também estágios nas diversas oficinas municipais, "a fim de desenvolver vocações, bem como o espírito criador da criança". (DIÁRIO DA MANHÃ, 1966).

A princípio, a informação da abertura dessa escola faz acender a seguinte dúvida: o Parque Infantil Peixe Abbade deixou de existir? Pois bem, não foi encontrada nenhuma informação se o parque se transformou em Escola Vocacional Parqueana ou se a Escola foi uma ampliação dos estudos naquele local. De acordo com as reportagens que foram noticiadas após abertura da Escola, chega-se à conclusão de que os dois eram apenas no mesmo local, mas com públicos distintos: o parque com as crianças mais novas e a escola com os pré-adolescentes.

Em 10 de outubro de 1980, o prefeito Dr. Antônio Duarte Nogueira, por meio da Lei $\mathrm{n}^{\circ}$ 3839 (RIBEIRÃO PRETO, 1980a), alterou a denominação dos parques infantis para Escolas Básicas de $1^{\circ}$ Grau e com isso o Parque Infantil Peixe Abbade ficou denominado Escola Básica Municipal de $1^{\circ}$ Grau "Peixe Abbade".

Em dezembro do mesmo ano, para efeito de direção administrativa e orientação pedagógica, o prefeito Dr. Antônio Duarte Nogueira unificou a Escola Básica Municipal de $1^{\circ}$ Grau "Peixe Abbade" e a Escola Municipal de 1 Grau "Professor Alfeu Luiz Gasparini", através da Lei no 3889 (RIBEIRÃO PRETO, 1980b). Contudo, de acordo com o parágrafo único do artigo $1^{\circ}$, "o setor da nova unidade administrativa que se dedica ao ensino de $1^{\circ}$ Grau permanecerá com a denominação de "Professor Alfeu Luiz Gasparini" e o setor destinado às classes de recreação infantil a pré-escola permanecerá com a denominação de "Peixe Abbade". (RIBEIRÃO PRETO, 1980b).

A Escola Municipal de Ensino de $1^{\circ}$ Grau virou a atual Escola Municipal de Ensino Infantil Professor Alfeu Luiz Gasparini em 1985, quando o prefeito João Gilberto Sampaio assinou a Lei no 4696 (RIBEIRÃO PRETO, 1985), que alterou a denominação das Escolas Básicas de $1^{\circ}$ Grau para Escolas Municipais de Educação Infantil. 


\subsubsection{Parque Infantil Amélia Junqueira}

Localização: Rua da Liberdade - Campos Elíseos.

Em 1952, o prefeito Cel. Alfredo Condeixa Filho, de acordo com o jornal A Tarde, de 08 de novembro de 1952, procurava meios para conseguir construir um parque infantil no Bosque Municipal Fábio Barreto, inclusive realizou um festival cuja renda foi revertida para "tão útil obra de grande alcance na defesa da criança, filha de operários daqueles dois progressistas bairros locais", no caso o Jardim Paulista e a Vila Paulista. O jornal A Tarde, de 28 de fevereiro de 1953, informou que estavam em andamento as obras do parque:

[...] em estilo moderno, eficiente e prático. Além do local privilegiado, pois tem uma vasta área onde a criança poderá se divertir, instruindo-se, há ainda a segurança natural. A sua inauguração será no dia dedicado às mães de todo mundo. A reportagem teve ocasião de fazer rápida visita na manhã de hoje ao local. O 'playground' será inteiramente reformado e modernizado, para bem atender à sua finalidade e incorporado ao parque. (A TARDE, 1953, p. 2).

O Parque Infantil do Bosque, também conhecido como Parque Infantil dos Campos Elíseos, foi inaugurado no dia 12 de maio de 1953. De acordo com o jornal A Tarde, de 02 de maio de 1953, o parque era dotado "do que há de mais moderno, além do pitoresco do lugar, sala de aula, descanso, piscina, divertimentos e plena assistência às crianças. Ali será o ponto de preferência do grande número de petizes de ambos os sexos”. (A TARDE, 1953, p. 9).

Oficialmente o parque foi criado 6 meses após sua inauguração, no dia 11 de novembro de 1953, por meio da Lei no 333 (RIBEIRÃO PRETO, 1953b), assinada pelo prefeito Cel. Alfredo Condeixa Filho.

Em março de 1957, o jornal Diário da Manhã publicou que no mês de fevereiro daquele ano, 3295 refeições foram oferecidas às crianças daquele parque. Em 1961 o número de refeições aumentou. Segundo o jornal Diário da Manhã de 04 de maio de 1961, no mês de abril foram servidos 6949 almoços, 5847 jantares, 6916 lanches e 342 copos de leite.

Em março de 1965, em um documento ${ }^{60}$ enviado ao Departamento de Educação e Cultura da cidade, foi relatado que naquele ano o parque estava acolhendo 350 crianças todos os dias.

No dia 13 de abril de 1965, o jornal Diário da Manhã publicou que naquele dia o parque estava oferecendo uma festa de páscoa, com inúmeras atrações, além de um almoço com

\footnotetext{
${ }^{60} \mathrm{O}$ documento pode ser encontrado no Arquivo Público e Histórico de Ribeirão Preto, no fundo Educação, na Pasta 32, $n^{\circ}$ de registro 357.
} 
distribuição de refrigerante aos presentes. No dia 30 do mesmo mês, o jornal publicou também que a diretora e as professoras do parque estavam realizando uma campanha para arrecadar agasalhos para as crianças parqueanas. O resultado dessa campanha foi noticiado no dia 23 de maio:

Foi coroada de completo êxito a campanha empreendida pela professora Doracy Chúfalo Patrick, do Parque Infantil 'Amélia Junqueira' do Bosque Municipal, que contando com o apoio incondicional de suas auxiliares e funcionários, conseguiu distribuir fartamente agasalhos aos parqueanos.

A festa de encerramento da referida campanha esteve muito animada com doces e balas para todos os presentes, constando também da substituição do uniforme usado pelas crianças que, de agora em diante, será azul.

Por nosso intermédio, aquela educadora agradece aos que colaboraram no humanitário movimento e participa que nenhum aluno ficou sem receber agasalhos para enfrentar o frio deste ano, que promete ser intenso. (DIÁRIO DA MANHÃ, 1965).

Em relação ao nome dado ao parque, não foi encontrado nenhum documento e nem a lei que o denominou Amélia Junqueira, mas no histórico da instituição ${ }^{61}$ é informado que ela foi homenageada por lutar e dignificar a cidade, principalmente por fundar o Orfanato "Madre Maria Mazarello" e por trazer as irmãs Salesianas para Ribeirão Preto, fundadoras do Colégio Auxiliadora.

Percebe-se que Amélia Junqueira já era o nome desse parque em 1961, de acordo com as figuras 23 e 24, que apresentam, além do nome do parque, a vista frontal e lateral do prédio, com o amplo gramado que tinha ao seu redor. Nota-se, julgando pelas fotografias, que a arquitetura faz lembrar um art déco simples. A figura 25 apresenta o parque com um grupo grande de alunos, professores e funcionários, e a figura 26 mostra as crianças em atividade na piscina, com vista do jardim e de um prédio que ficava ao lado do parque.

\footnotetext{
${ }^{61}$ PREFEITURA MUNICIPAL DE RIBEIRÃO PRETO. EMEI Amélia Junqueira. Disponível em: $\langle$ https://www.ribeiraopreto.sp.gov.br/seducacao/escolas/ajunqueira/i15ajunqueira.php>. Acesso em: 25 maio 2015.
} 
Figura 23 - Parque Infantil Amélia Junqueira

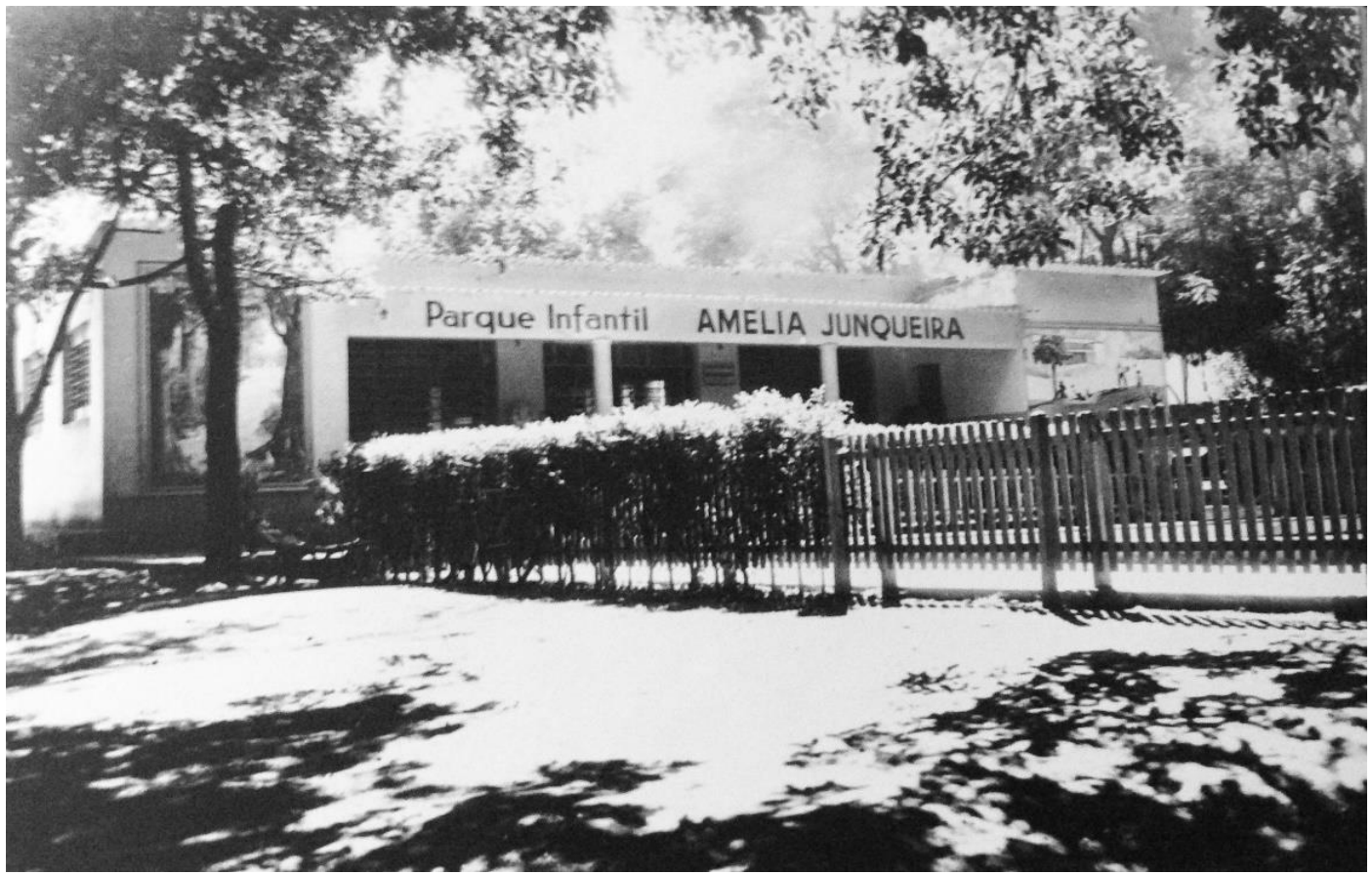

Fonte: AGUIAR $(1963)^{62}$

Figura 24 - Parque Infantil Amélia Junqueira, setembro de 1961. Foto: Miyasaka

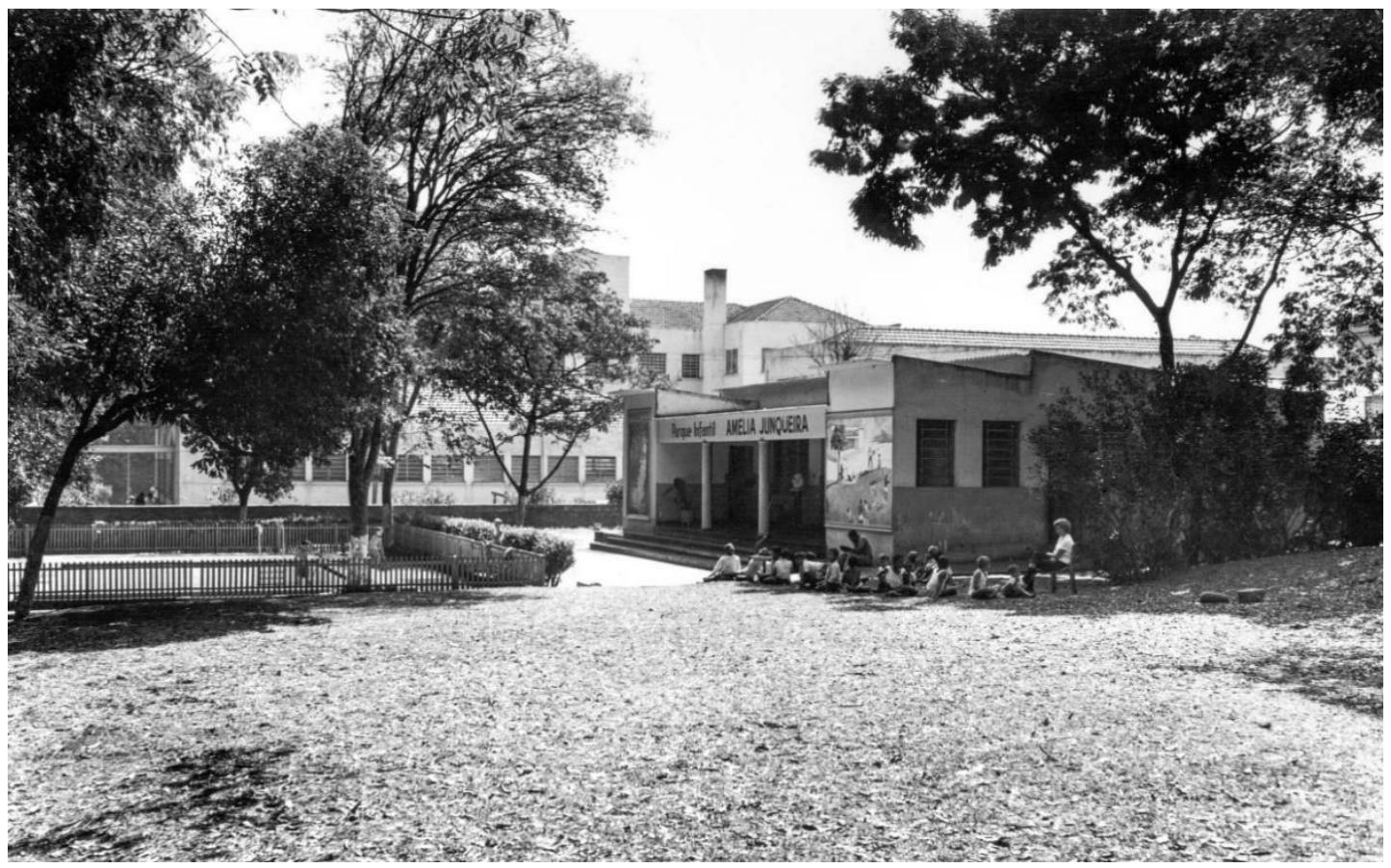

Fonte: Arquivo Público e Histórico de Ribeirão Preto ${ }^{63}$

${ }^{62}$ Fotografia retirada do Álbum histórico e fotográfico dos postos odontológicos do serviço dentário municipal de Ribeirão Preto, organizado por Augusta Aguiar em 1963, depositado no Arquivo Público e Histórico de Ribeirão Preto, no Fundo Cel. Alfredo Condeixa Filho.

${ }^{63}$ A fotografia pode ser encontrada no Arquivo Público e Histórico de Ribeirão Preto, no fundo Cel. Alfredo Condeixa Filho, na Pasta 87, ${ }^{\circ}$ de registro 1079. 
Figura 25 - Parque Infantil Amélia Junqueira, setembro de 1961. Foto: Miyasaka

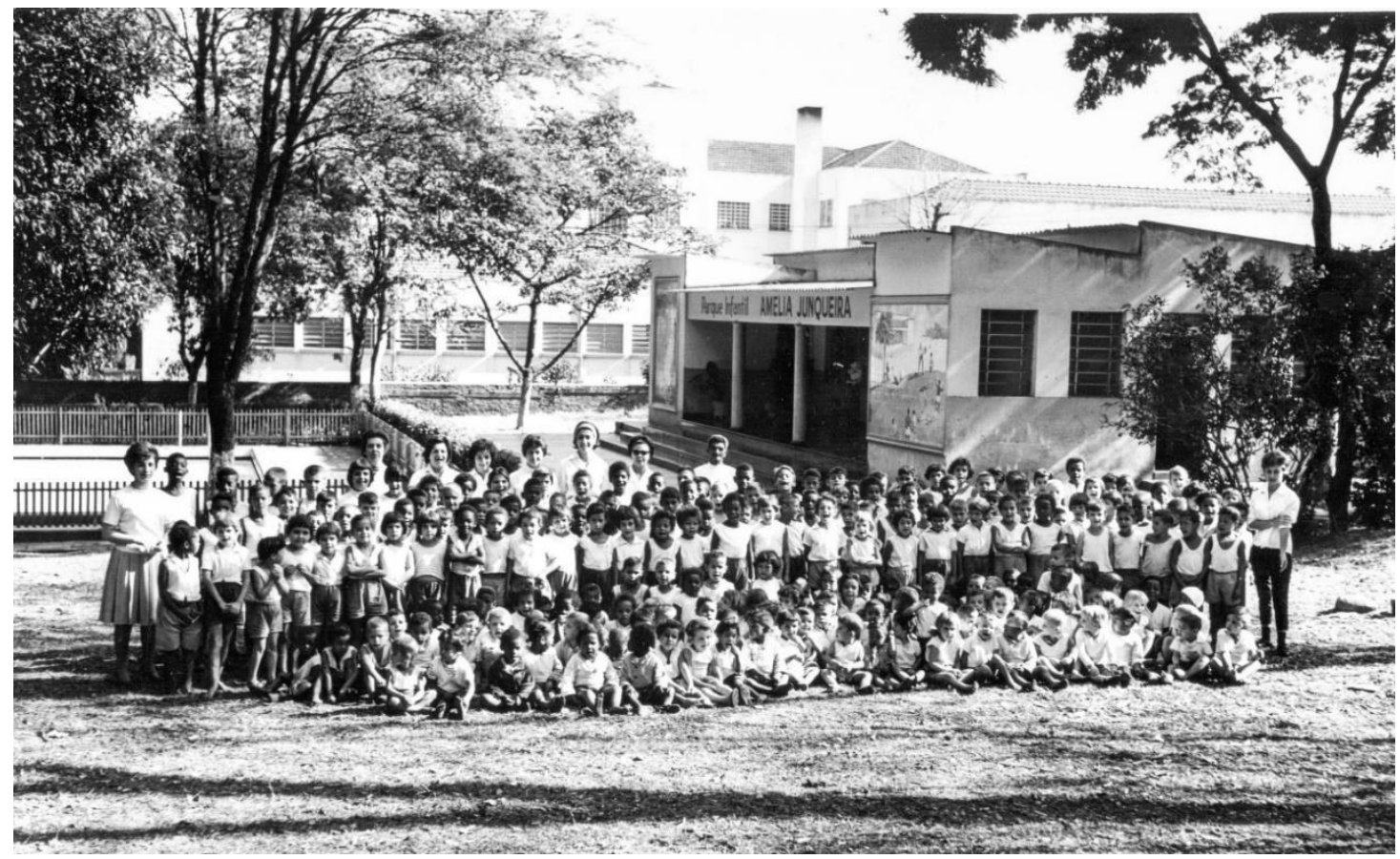

Fonte: Arquivo Público e Histórico de Ribeirão Preto ${ }^{64}$

Figura 26 - Parque Infantil Amélia Junqueira, setembro de 1961. Foto: Miyasaka

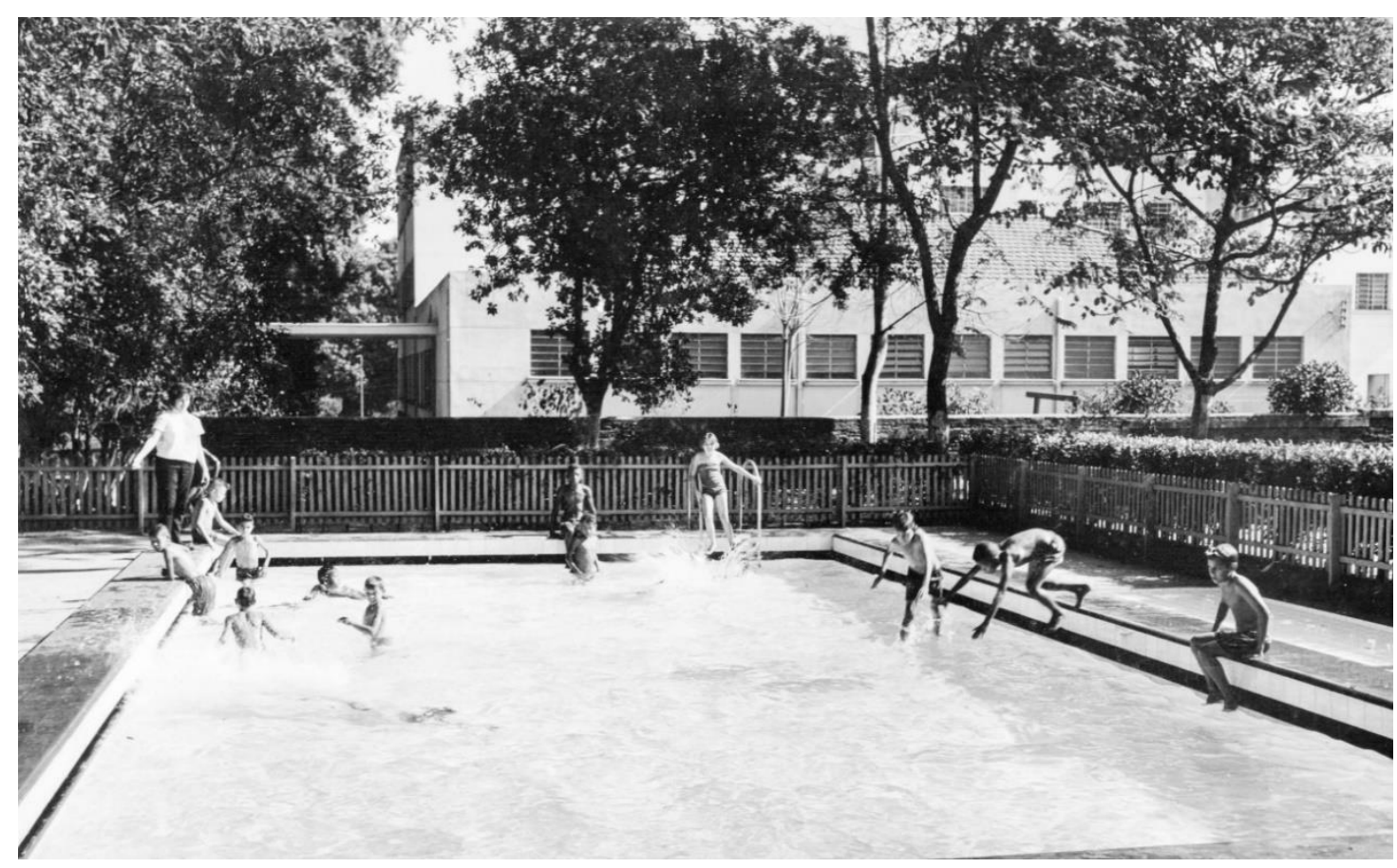

Fonte: Arquivo Público e Histórico de Ribeirão Preto ${ }^{65}$

${ }^{64}$ A fotografia pode ser encontrada no Arquivo Público e Histórico de Ribeirão Preto, no fundo Cel. Alfredo Condeixa Filho, na Pasta 87, ${ }^{\circ}$ de registro 1080.

${ }^{65}$ Ibidem, $\mathrm{n}^{\mathrm{o}}$ de registro 1083. 
Há uma nota no jornal Diário da Manhã de 1966 relatando que houve instalações de Escolas Vocacionais Parqueanas em todos os parques infantis da cidade. Entretanto, não foi encontrada a data da inauguração de uma Escola Vocacional nesse parque e nem outras informações.

De acordo com o histórico da instituição, em decorrência do perigo do local do parque infantil, em 1989, as crianças "foram transferidas para o antigo prédio da SUDERP, sendo [a escola] denominada, através do Processo CEE 0271/84, publicado no DOM de 13/11/84, EMEI Amélia Junqueira, situada na Avenida Treze de Maio, $n^{0}$ 65, bairro: Jardim Paulistano". (PREFEITURA MUNICIPAL DE RIBEIRÃO PRETO) ${ }^{66}$.

\subsubsection{Parque Infantil Anita Procópio Junqueira}

Localização: Rua 21 de Abril, 570 - Vila Tibério.

O Parque Infantil Anita Procópio Junqueira, primeiramente conhecido como Parque Infantil da Vila Tibério, teve o lançamento da sua pedra fundamental em 10 de maio de 1953, de acordo com os Álbuns 1 e 3 depositados no Arquivo Público e Histórico de Ribeirão Preto, no fundo Cel. Alfredo Condeixa Filho (figura 27). O lançamento também foi noticiado no jornal A Tarde, no dia 02 de maio de 1953: "No dia das mães, será lançada a pedra fundamental do Parque Infantil da Vila Tibério cujo orçamento é superior a 500.000 cruzeiros, esperando-se que o mesmo esteja pronto antes do fim do ano". (A TARDE, 1953, p. 9).

${ }^{66}$ PREFEITURA MUNICIPAL DE RIBEIRÃO PRETO. EMEI Amélia Junqueira. Disponível em: <https://www.ribeiraopreto.sp.gov.br/seducacao/escolas/ajunqueira/i15ajunqueira.php>. Acesso em: 25 maio 2015. 
Figura 27 - Álbum 1 - Lançamento da pedra fundamental do Parque Infantil da Vila Tibério

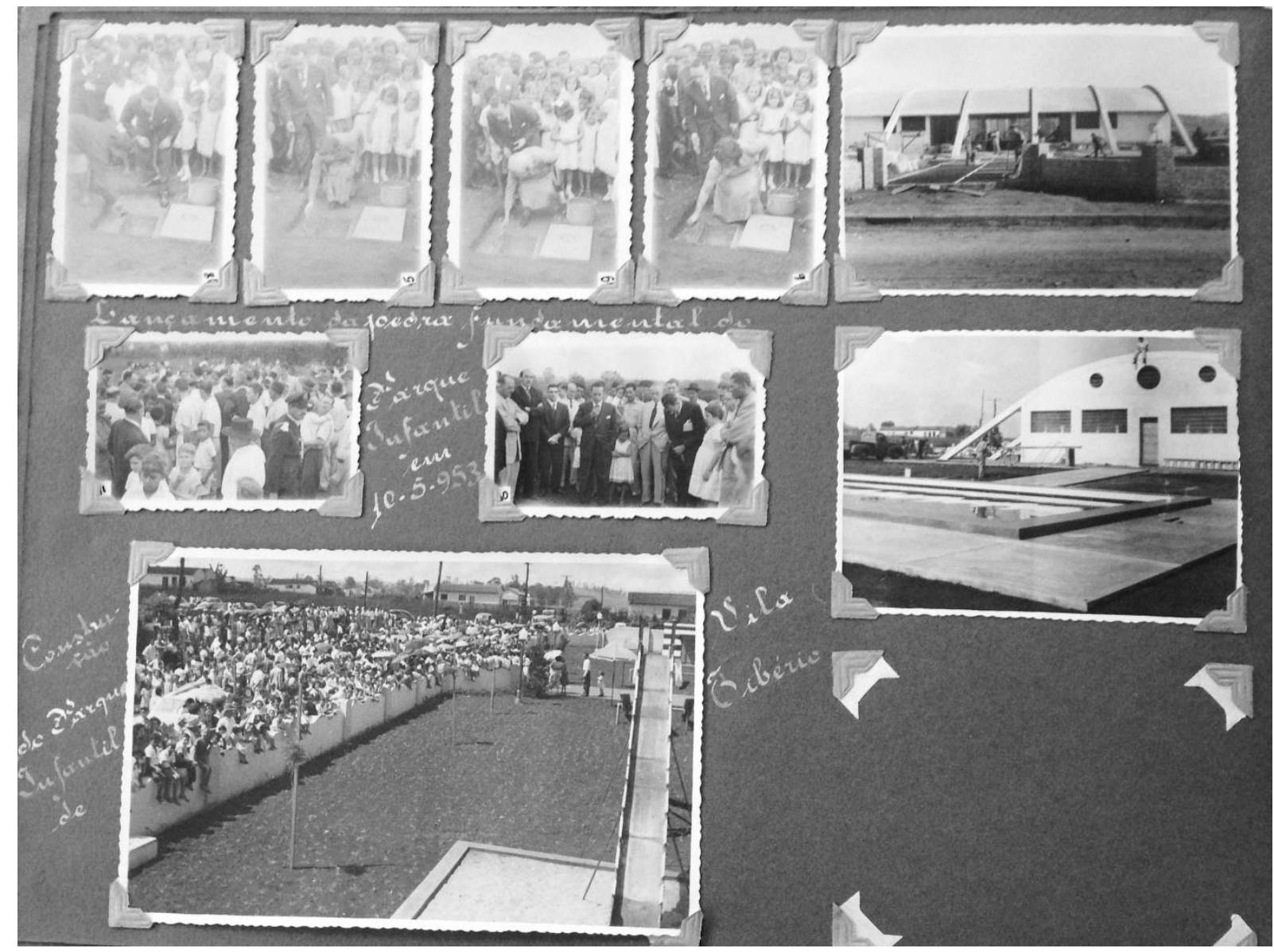

Fonte: Arquivo Público e Histórico de Ribeirão Preto ${ }^{67}$

O parque infantil não foi inaugurado em 1953, e sim no final do ano seguinte, no dia 08 de dezembro de 1954, com importantes representantes municipais e nesse mesmo dia já foram inaugurados o consultório médico, o gabinete odontológico e a piscina (figura 28).

${ }^{67}$ O Álbum pode ser encontrado no Arquivo Público e Histórico de Ribeirão Preto, no fundo Cel. Alfredo Condeixa Filho. 
Figura 28 - Álbum 1 - Inauguração da piscina do Parque Infantil da Vila Tibério

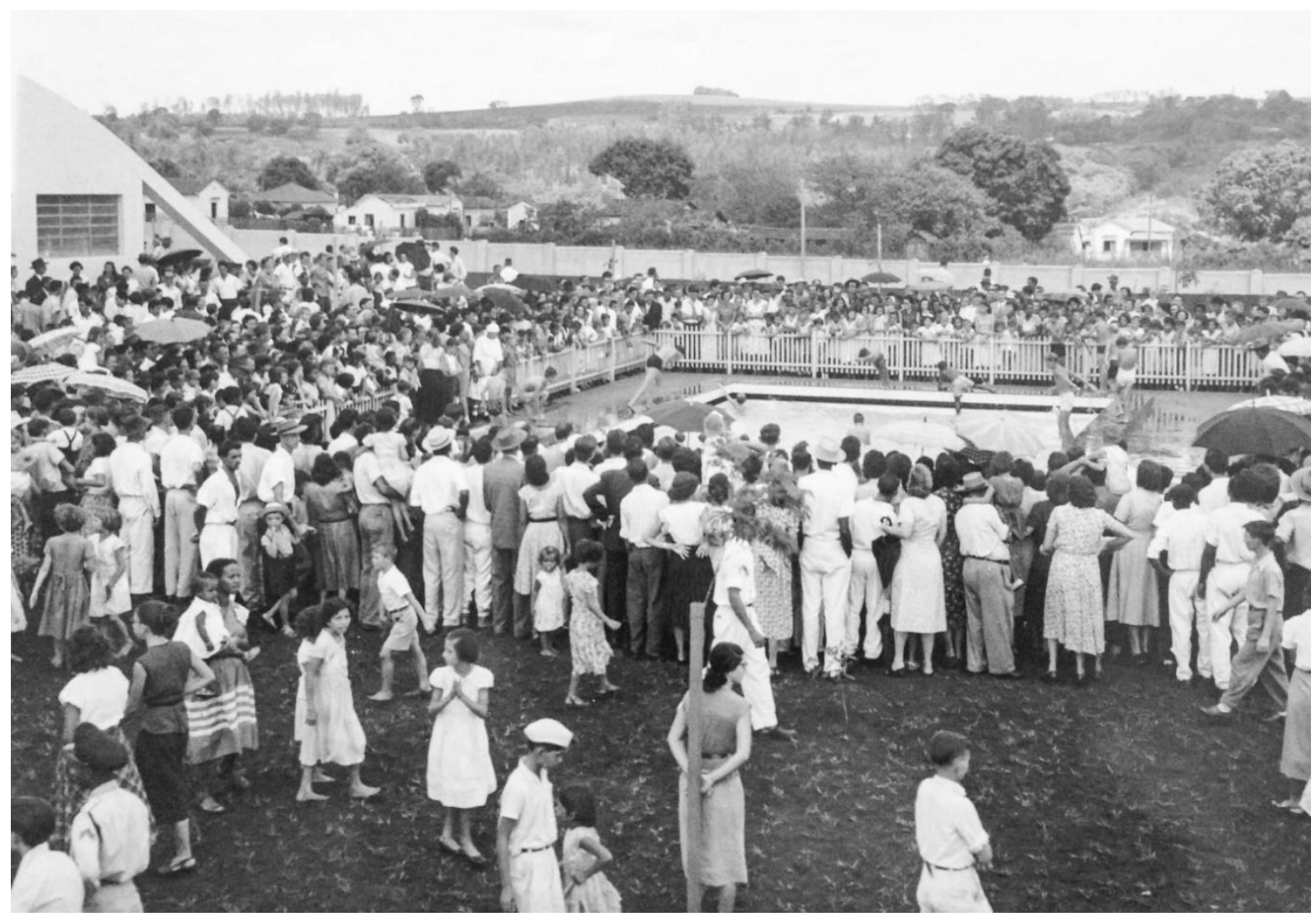

Fonte: Arquivo Público e Histórico de Ribeirão Preto ${ }^{68}$

O interessante é que o lançamento da pedra fundamental (em 1953) e a inauguração (em 1954) são anteriores às leis referentes a esse parque. A primeira vez que o Parque Infantil da Vila Tibério apareceu na legislação municipal foi em 20 de junho de 1955, quando o prefeito José Costa assinou Lei no 421 (RIBEIRÃO PRETO, 1955a) declarando de utilidade pública um terreno para construção do Parque Infantil da Vila Tibério:

Artigo $1^{\circ}$ - Fica declarada de utilidade pública, para o fim de ser desapropriada judicial ou amigavelmente, nos têrmos do artigo $5^{\circ}$ do Decreto-lei Federal $n$. 3365 de 21-6-941, e do ${ }^{\circ}$ IV do artigo 16 da Lei n. 1, de 18 de Setembro de 1.947, a gleba de terreno abaixo descrita, para nela ser construído o Parque Infantil do bairro de Vila Tibério, a saber:

- Uma gleba de terreno de fórma regular, fechado de cêrca viva, de propriedade dos herdeiros e sucessores de Augusto Junqueira, ou de quem de direito, contendo as seguintes dimensões: pela frente da rua 21 de Abril 87,95 metros lineares, frente da rua Constituição 88,90 metros lineares, frente da rua Aurora 88,90 metros lineares e frente da rua Álvares de Azevedo 89,90 metros lineares, com área total de 7.901,00 metros quadrados. (RIBEIRÃO PRETO, 1955a).

${ }^{68} \mathrm{O}$ Álbum pode ser encontrado no Arquivo Público e Histórico de Ribeirão Preto, no fundo Cel. Alfredo Condeixa Filho. 
Há uma carta ${ }^{69}$, depositada no Arquivo, que o Chefe da Seção de Cadastro e Patrimônio enviou para o prefeito Cel. Alfredo Condeixa Filho em 08 de março de 1952. Nessa carta, ele comunica ao prefeito que, para a instalação do parque, já haviam sido feitas as plantas e memoriais para a desapropriação por via amigável ou judicial do terreno. A partir de então, o parque foi construído, lançado, inaugurado e só oficialmente criado em 16 de fevereiro de 1957, pelo prefeito Costabile Romano, por meio da Lei no 547 (RIBEIRÃO PRETO, 1957a). No mesmo ano, em 17 de agosto, o mesmo prefeito denominou o Parque Infantil da Vila Tibério de "Dona Anita Procópio Junqueira", através da Lei no 588 (RIBEIRÃO PRETO, 1957b). De acordo com o histórico da instituição, Anita Junqueira foi homenageada pois:

durante sua vida, deixou uma tradição de trabalho e abnegação em prol dos desfavorecidos pela sorte, com especial atenção pela infância abandonada e também pelas famílias dos combatentes da II Guerra Mundial, pracinhas nas linhas de frente de combate.

Considerada uma anfitriã perfeita, conseguiu representar nossa cidade com dignidade frente a ministros, secretários, parlamentares e titulares de toda ordem que vinham à nossa cidade e eram hospedados em sua fazenda 'Brejinho' em Bonfim Paulista. (PREFEITURA DE RIBEIRÃO PRETO) ${ }^{70}$.

Logo após a sua inauguração, em 14 dezembro de 1954, o jornal Diário da Manhã publicou uma pequena nota informando que o parque havia recebido doações de brinquedos destinados ao natal das crianças pertencentes àquele parque, do Sr. Dante Castro e que o gesto era "digno de ser imitado para gaudio das crianças pobres". (DIÁRIO DA MANHÃ, 1954, p. 4). Em 30 de março de 1955 o mesmo jornal publicou que o parque estava numa campanha próaquisição de materiais esportivos e que havia acabado de conseguir, por intermédio do Sr. Antônio Zilioto, uma bola de futebol. Novamente destacavam que o "gesto [é] digno de ser imitado, pois a garotada parqueana bem o merece". (DIÁRIO DA MANHÃ, 1955, p. 7).

De acordo com o Álbum comemorativo do $1^{o}$ centenário da fundação da cidade do Ribeirão Preto $^{71}$ (COSTA, J., 1956), em março de 1956 esse parque era o maior da cidade e também com número superior de matrículas e refeições servidas durante aquele mês ${ }^{72}$. Outra

\footnotetext{
${ }^{69} \mathrm{O}$ documento pode ser encontrado no Arquivo Público e Histórico de Ribeirão Preto, no fundo Prefeitura Municipal, na caixa $4, \mathrm{n}^{\mathrm{o}}$ de registro 106.

${ }^{70}$ PREFEITURA MUNICIPAL DE RIBEIRÃO PRETO. EMEI Anita Procópio Junqueira. Disponível em: <https://www.ribeiraopreto.sp.gov.br/seducacao/escolas/anita/i15anita.php>. Acesso em: 25 maio 2015.

${ }^{71} \mathrm{O}$ Álbum comemorativo do $1^{o}$ centenário da fundação da cidade do Ribeirão Preto, organizado por João Emboaba da Costa em 1956, está depositado no Arquivo Público e Histórico de Ribeirão Preto, no Fundo Cel. Alfredo Condeixa Filho, caixa 20, pasta 33, registro 377.

72 O Parque Infantil Peixe Abbade tinha 2156 matriculados, com 400 frequentes diários; No Parque Infantil Campos Elíseos havia 1098 matrículas e 170 de frequência; No Parque Infantil de Bonfim Paulista 90 matrículas e 40 de frequência. Já o Parque Infantil da Vila Tibério tinha 2870 matriculados, com 800 de frequência. (COSTA, J., 1956).
} 
informação importante nesse Álbum é que quando as crianças voltavam para suas casas, por meio de um caminhão improvisado da prefeitura, cada uma recebia um pãozinho de 150 gramas feito no próprio parque. Pode-se notar na figura 29, o cesto de pão no veículo e as professoras entregando-os para cada criança.

\section{Figura 29 - Transporte e alimentação no Parque Infantil da Vila Tibério}

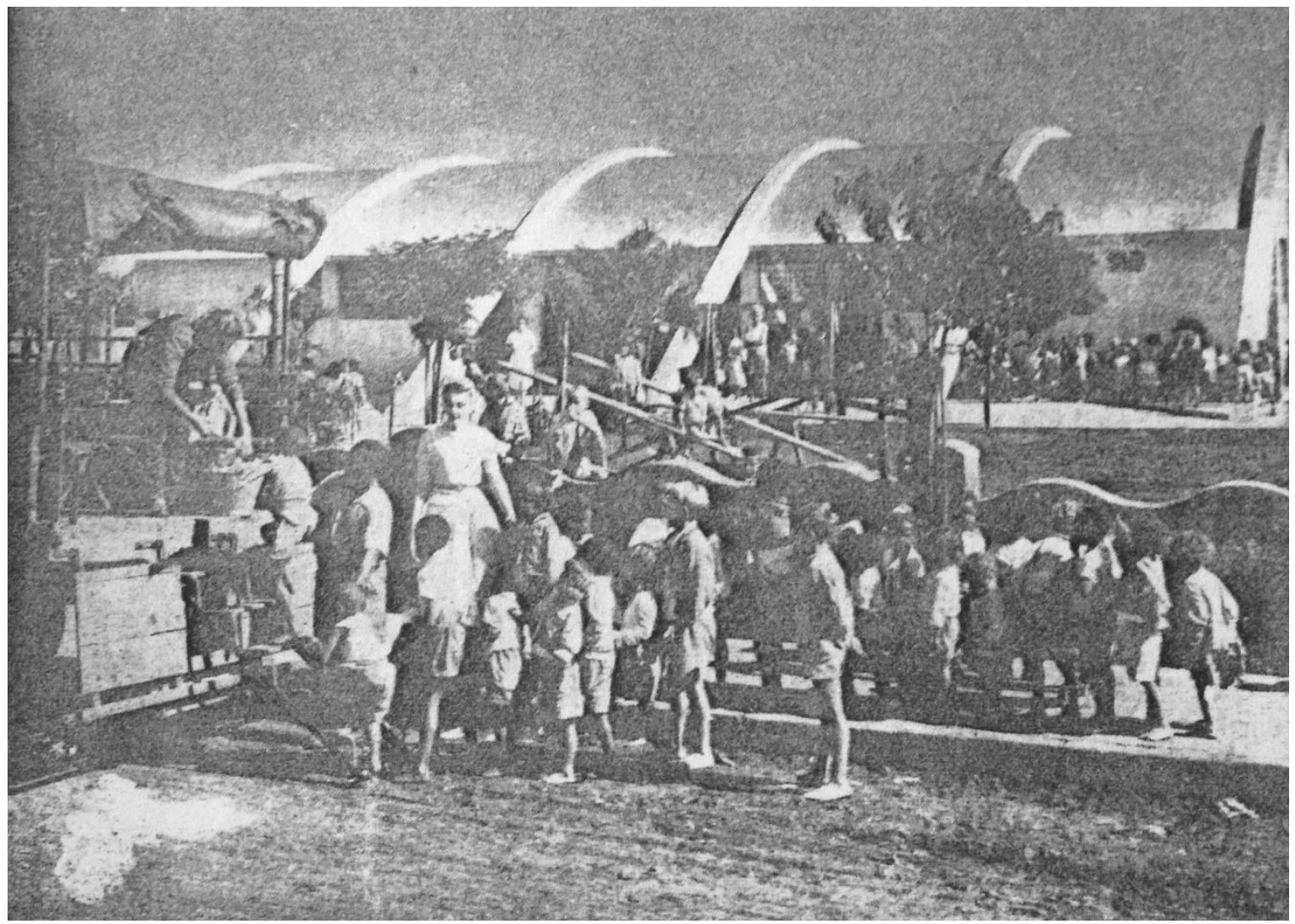

Fonte: Arquivo Público e Histórico de Ribeirão Preto ${ }^{73}$

As figuras seguintes, 30 e 31 mostram como era o prédio do parque. A figura 30, tomada a partir de um ponto no alto, apresenta a vista do prédio, jardins, gramado e grupo de crianças durante atividade. No fundo, há vista da silhueta das arquibancadas e torres de iluminação do estádio Luiz Pereira, do Botafogo Futebol Clube. Já na figura 31, pode-se notar a vista lateral do parque com destaque a sua arquitetura, que tem nitidamente inspiração modernista, com ênfase na estrutura limpa e aparente e formas mais puras, particularmente na exploração plástica e estrutural da caixa d'água e dos arcos, mas com a presença de janelas redondas encontradas numa variante chamada "aerodinâmica" do art déco.

${ }^{73} \mathrm{O}$ Álbum comemorativo do $1^{o}$ centenário da fundação da cidade do Ribeirão Preto, organizado por João Emboaba da Costa em 1956, está depositado no Arquivo Público e Histórico de Ribeirão Preto, no Fundo Cel. Alfredo Condeixa Filho, caixa 20, pasta 33, registro 377. 
O reservatório d'água observado é chamado também de cogumelo elevado. Segundo o jornal Diário da Manhã, de 30 de setembro de 1962, foi construído naquele ano e tem capacidade de 500 mil litros, com altura de 27 metros.

A figura 32 mostra a vista da piscina e do prédio do parque. Há crianças realizando atividades na piscina. Dois garotos assistem à cena junto a uma cerca de madeira e uma professora supervisiona a atividade.

Figura 30 - Parque Infantil Anita Procópio Junqueira, setembro de 1961. Foto: Miyasaka

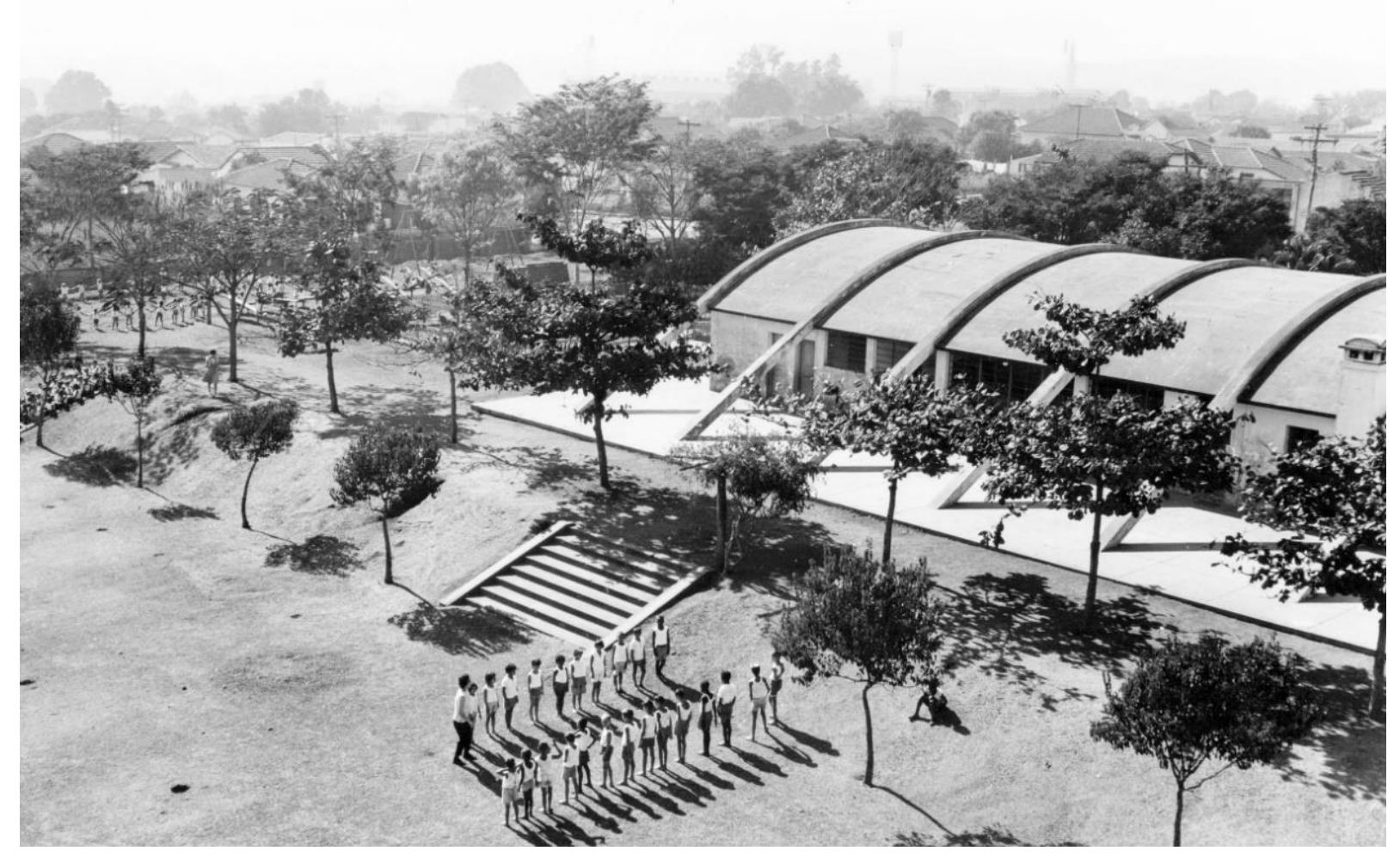

Fonte: Arquivo Público e Histórico de Ribeirão Preto ${ }^{74}$

\footnotetext{
${ }^{74}$ A fotografia pode ser encontrada no Arquivo Público e Histórico de Ribeirão Preto, no fundo Cel. Alfredo Condeixa Filho, na Pasta 88, nº de registro 1086.
} 
Figura 31 - Parque Infantil Anita Procópio Junqueira

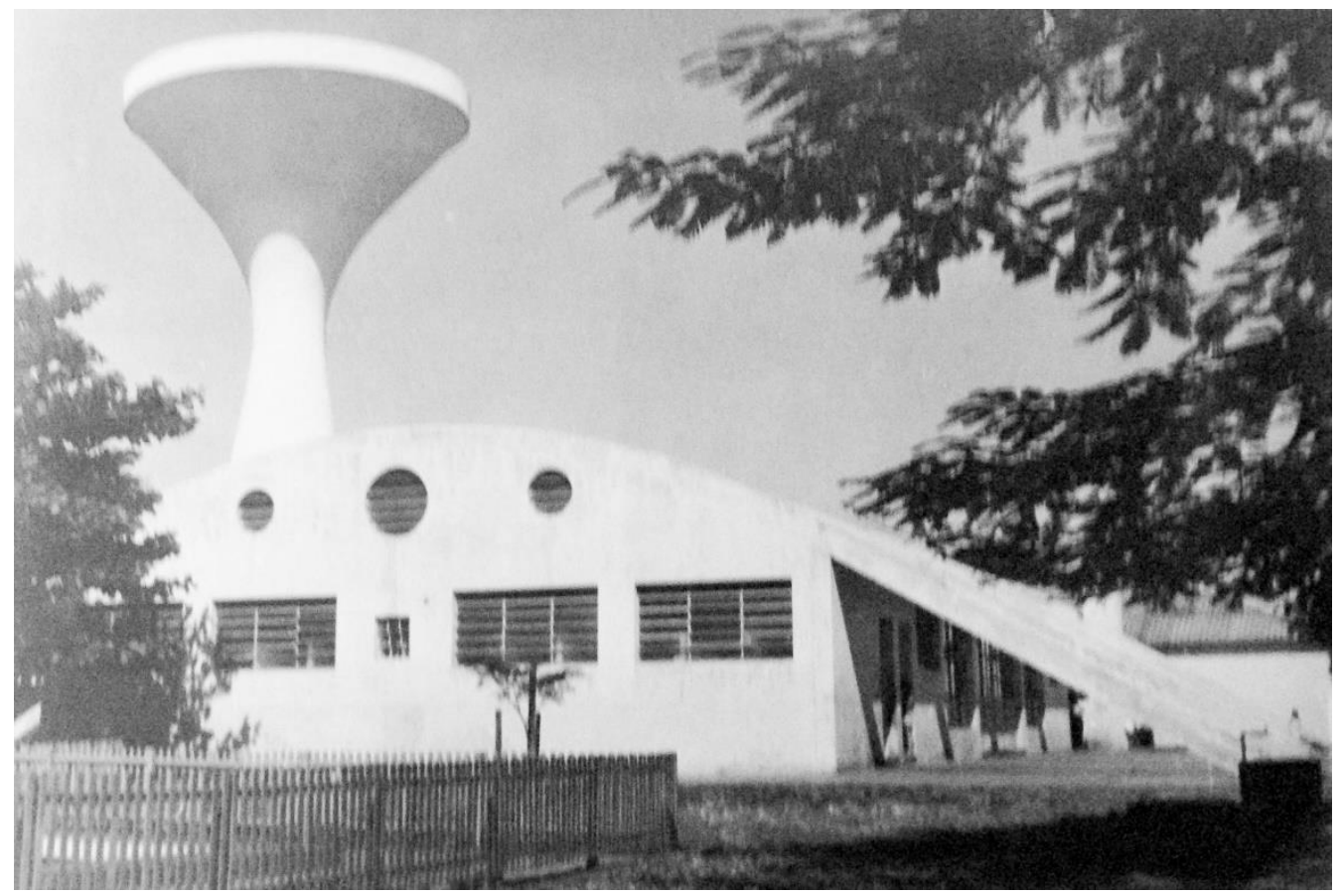

Fonte: AGUIAR $(1963)^{75}$

Figura 32 - Piscina do Parque Infantil Anita Procópio Junqueira, setembro de 1961. Foto: Miyasaka

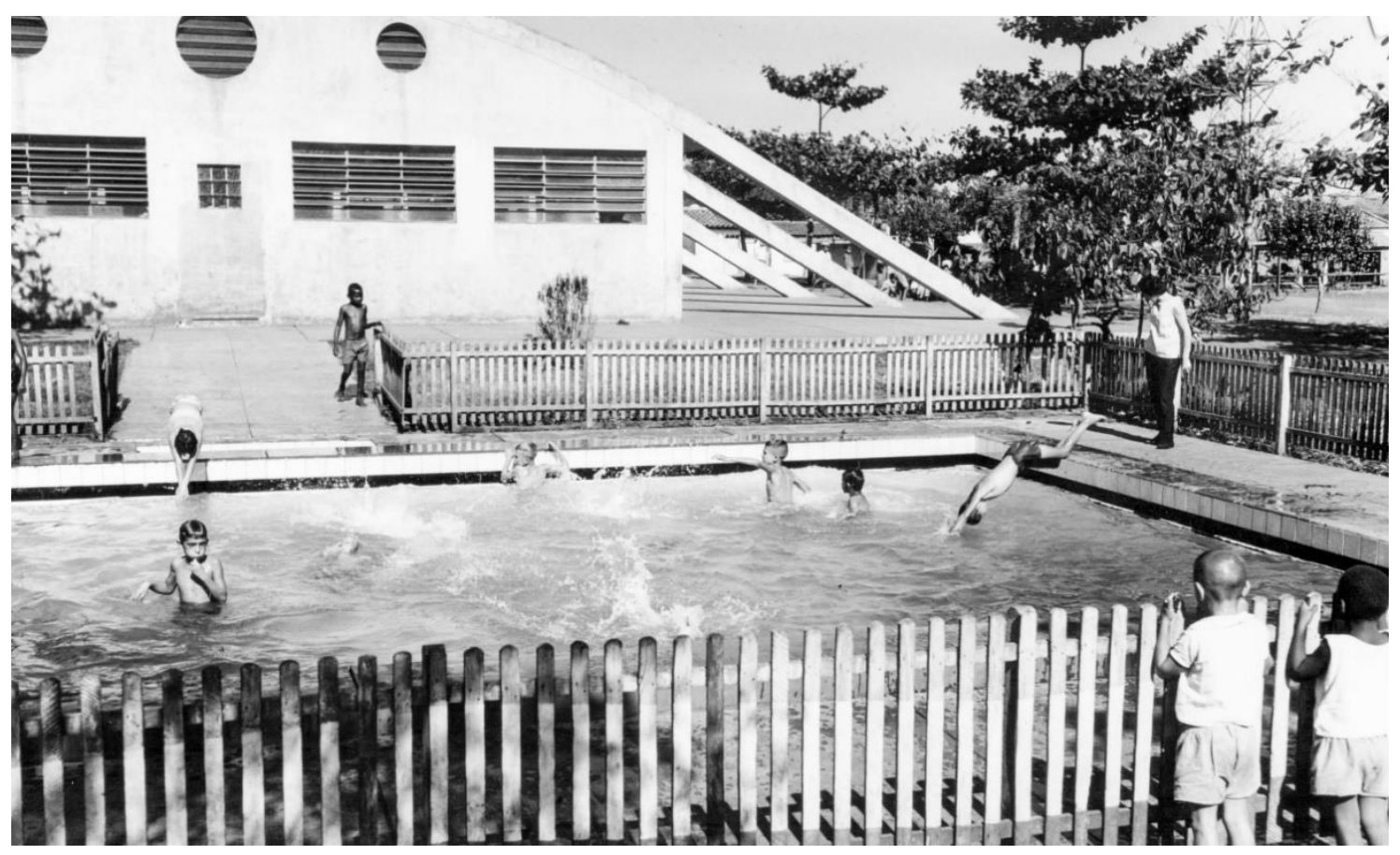

Fonte: Arquivo Público e Histórico de Ribeirão Preto ${ }^{76}$

\footnotetext{
${ }^{75}$ Fotografia retirada do Álbum histórico e fotográfico dos postos odontológicos do serviço dentário municipal de Ribeirão Preto, organizado por Augusta Aguiar em 1963, depositado no Arquivo Público e Histórico de Ribeirão Preto, no Fundo Cel. Alfredo Condeixa Filho.

${ }^{76}$ A fotografia pode ser encontrada no Arquivo Público e Histórico de Ribeirão Preto, no fundo Cel. Alfredo Condeixa Filho, na Pasta 88, $\mathrm{n}^{\circ}$ de registro 1088.
} 
Em 03 de maio de 1961 o jornal Diário da Manhã publicou uma pequena nota informando que o prefeito Cel. Alfredo Condeixa Filho tinha recebido o relatório referente ao mês de abril do Parque Infantil Anita Procópio Junqueira e que teve o seguinte movimento: 3788 almoços servidos às crianças; 3614 lanches e 2651 jantares, perfazendo um total de 10.053 refeições; informou também que foram executados 130 cortes de cabelo. No final de 1961, o mesmo jornal publicou que o parque tinha comemorado seu $7^{\circ}$ aniversário e que o prefeito, Cel. Alfredo Condeixa Filho, havia visitado o parque. Na ocasião de sua visita,

os meninos cantaram o Hino oficial do Parque e feita a visita às suas dependências, que merecem reparo especial, eis que ali está um dos motivos de atração de nossa cidade: foram os visitantes apreciar a disputa de natação entre os parqueanos da Vila Tibério, Barracão e Bosque Municipal, decorrendo no meio do maior entusiasmo.

[...] A impressão colhida foi das mais significativas e traduzidas nas palavras do prefeito Condeixa Filho sobre tudo quanto lhes fora dado ver no local, louvando, ainda, o magnífico estado de saúde daquelas 500 crianças que ali recebem assistência e se preparam para as árduas lutas do dia de amanhã, graças à eficiência da direção e do corpo docente. (DIÁRIO DA MANHÃ, 1961, p. 14).

Três anos depois, em comemoração ao decênio do parque infantil, uma missa campal foi realizada no dia 08 de dezembro de 1964. De acordo com o jornal Diário da Manhã do dia 06 de dezembro, essa missa também foi a de primeira comunhão de alguns parqueanos.

Há um documento ${ }^{77}$, de 12 de março de 1965, informando que naquele ano esse parque acolhia 320 crianças todos os dias. Em outro documento ${ }^{78}$, de 07 de outubro do mesmo ano, é relatado tudo o que seria feito na semana da criança: exposição de trabalhos das crianças no salão de festas do parque; disputa de futebol entre os parqueanos desse parque contra os do parque do Barracão; números artísticos apresentados pelas crianças; uma visita dos parqueanos de Bonfim Paulista com almoço especial; competição de natação entre os garotos desse parque contra os da Vila Virgínia; visita dos parqueanos ao Museu Municipal; e o mais interessante, doação, pelos funcionários, de uma botina ortopédica ao parqueano José Evaristo Rosa, provando que realmente os professores e funcionários se preocupavam e faziam o possível para ajudar essas crianças, assim como as entrevistadas por Darahem (2011) e Ferreira (2010) relataram.

No dia 08 de julho de 1965, o prefeito Dr. Welson Gasparini visitou o parque infantil. Segundo o jornal Diário da Manhã, a visita foi longa e se fez necessária quando o prefeito tomou

\footnotetext{
77 O documento pode ser encontrado no Arquivo Público e Histórico de Ribeirão Preto, no fundo Educação, na Pasta 32, $\mathrm{n}^{\circ}$ de registro 357.

${ }^{78} \mathrm{O}$ documento pode ser encontrado no Arquivo Público e Histórico de Ribeirão Preto, no fundo Educação, na Pasta 25, $\mathrm{n}^{\mathrm{o}}$ de registro 304.
} 
conhecimento das ininterruptas atividades da diretoria e da caixa parqueana beneficente daquele local, que havia acabado de adquirir, mediante colaboração da população ribeirão-pretana, uma rádio vitrola portátil: “aquele aparelho, dotado de som estereofônico será aproveitado para irradiação de contos instrutivos e músicas folclóricas brasileiras, despertando desde agora nas crianças, interesse pela cultura e amor à Pátria Brasileira”. (DIÁRIO DA MANHÃ, 1965).

Em 23 de abril de 1966, o jornal Diário da Manhã informou que o prefeito Dr. Welson Gasparini havia inaugurado uma Escola Vocacional Parqueana no Parque Infantil Anita Procópio Junqueira. Essa escola tinha como intuito dar às crianças um ensinamento aprimorado, principalmente no que diz respeito às atividades técnicas cotidianas.

Em 1 de outubro de 1980, ao assinar a Lei no 3839 (RIBEIRÃO PRETO, 1980a) o prefeito Dr. Antônio Duarte Nogueira tornou o parque em Escola Básica de $1^{\circ}$ Grau “Anita Procópio Junqueira” e em 1985, através da Lei no 4696 (RIBEIRÃO PRETO, 1985), o prefeito João Gilberto Sampai tornou Escola Básica de $1^{\circ}$ Grau “Anita Procópio Junqueira” na atual Escola Municipal de Ensino Infantil Anita Procópio Junqueira.

\subsubsection{Parque Infantil Dona Iria Junqueira}

Localização: Rua Dr. Marciano, 126 - Bonfim Paulista.

O Parque Infantil Dona Iria Junqueira foi criado em 11 de julho de 1955, pelo prefeito José Costa, por meio da Lei no 425 (RIBEIRÃO PRETO, 1955b). O parque era conhecido por três nomes: Parque Infantil de Bonfim Paulista ${ }^{79}$ - pois era o único parque desse distrito de Ribeirão, Parque Infantil Vila Bonfim ou como Recanto $4^{\circ}$ Centenário. Apenas em 15 de janeiro de 1968, por meio da Lei no 2039 (RIBEIRÃO PRETO, 1968b), é que teve seu nome alterado pelo prefeito Dr. Welson Gasparini, que o denominou "Dona Iria Junqueira".

É interessante relatar que, no jornal Diário da Manhã do dia 1 de julho de 1955, há uma pequena nota: "depois de estar funcionando há mais de um ano a Câmara houve por bem aprovar a criação do Parque Infantil de Vila Bonfim. Ainda bem”. (DIÁRIO DA MANHÃ, 1955). Isso prova que o parque estava funcionado desde 1954.

No Arquivo Público e Histórico de Ribeirão Preto há um Álbum, do fundo Cel. Alfredo Condeixa Filho, que apresenta fotografias do Miyasaka do dia da inauguração desse parque

\footnotetext{
${ }^{79}$ Bonfim Paulista ainda é um distrito de Ribeirão Preto e é representado pelo subsetor S-9.
} 
(figura 33). Pode-se notar que houve uma solenidade de inauguração, a qual contou com apresentação das crianças para as autoridades.

Figura 33 - Álbum 2 - Inauguração do Parque Infantil de Bonfim Paulista

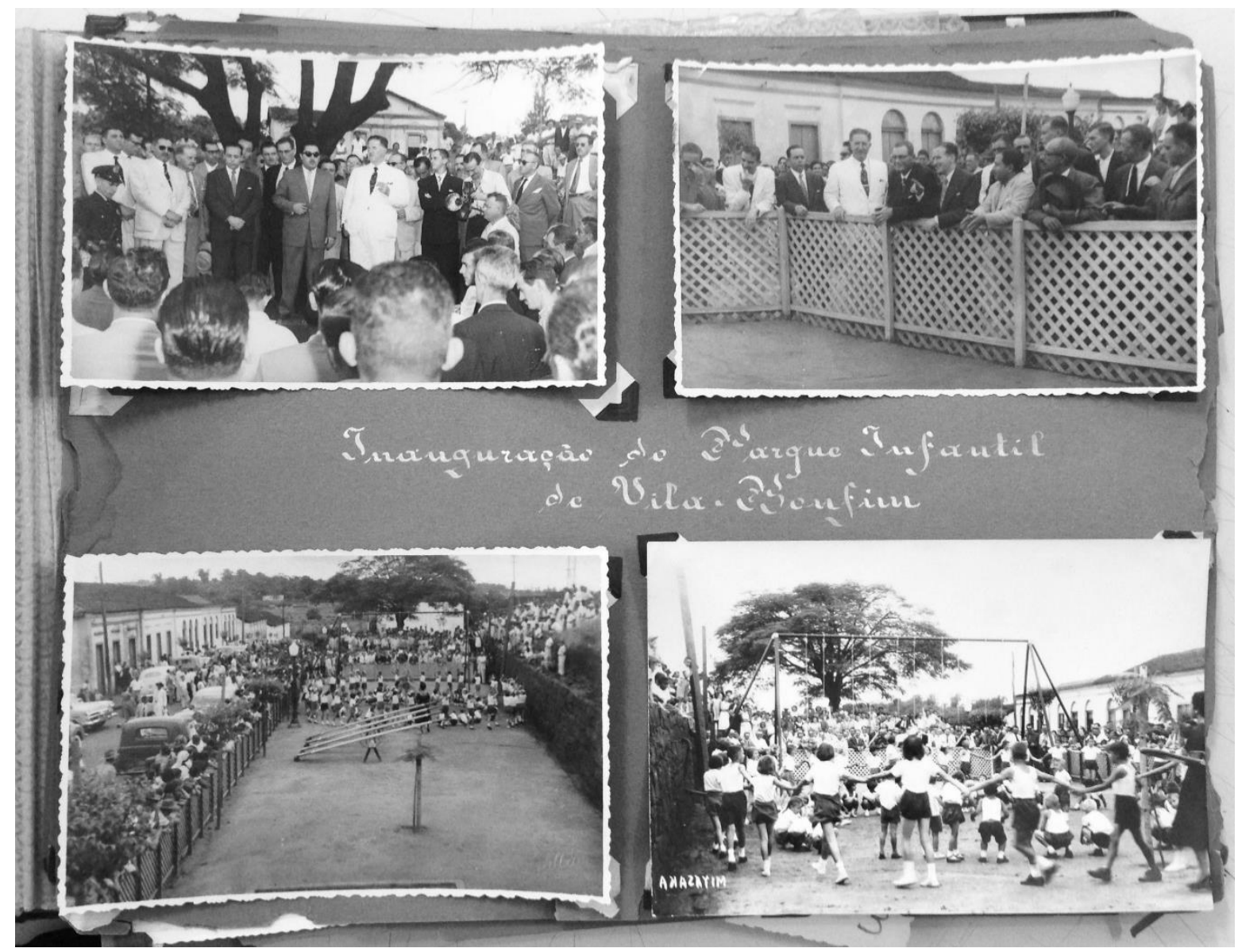

Fonte: Arquivo Público e Histórico de Ribeirão Preto ${ }^{80}$

De acordo com o Álbum comemorativo do $1^{\circ}$ centenário da fundação da cidade do Ribeirão Preto (COSTA, J., 1956), em março de 1956 o parque tinha 90 crianças matriculadas, com frequência de 40 crianças por dia e 1200 refeições mensais.

Não há muitas informações e imagens sobre este parque. Todavia, as figuras 34, 36 e 37, mostram um pouco de seu cotidiano. Na figura 34, pode-se ver um gramado com balanços e gangorras, com as crianças em atividades nos brinquedos e brincando de roda. Há presença de duas mulheres, uma possível professora com as crianças na roda, e outra, possível funcionária, no interior do galpão olhando os pequenos. Essa é a única que imagem que nos

\footnotetext{
${ }^{80} \mathrm{O}$ Álbum pode ser encontrado no Arquivo Público e Histórico de Ribeirão Preto, no fundo Cel. Alfredo
} Condeixa Filho. 
mostra a arquitetura externa desse parque. Nota-se também que, das 25 crianças que aparecem na imagem, somente uma menina não está descalça (figura 35).

A figura 36 revela a vista do galpão onde crianças faziam sua refeição juntas, em mesas de quatro lugares. Elas comem em pratos fundos e com colheres e há três possíveis funcionárias vigiando as crianças. A figura 37 mostra como era feita a alimentação dessas crianças, mostrando a cozinha com fogão de lenha e a cozinheira está preparando alimentos em duas grandes panelas e caldeirão.

Figura 34 - Parque Infantil Dona. Iria Junqueira, setembro de 1961. Foto: Miyasaka

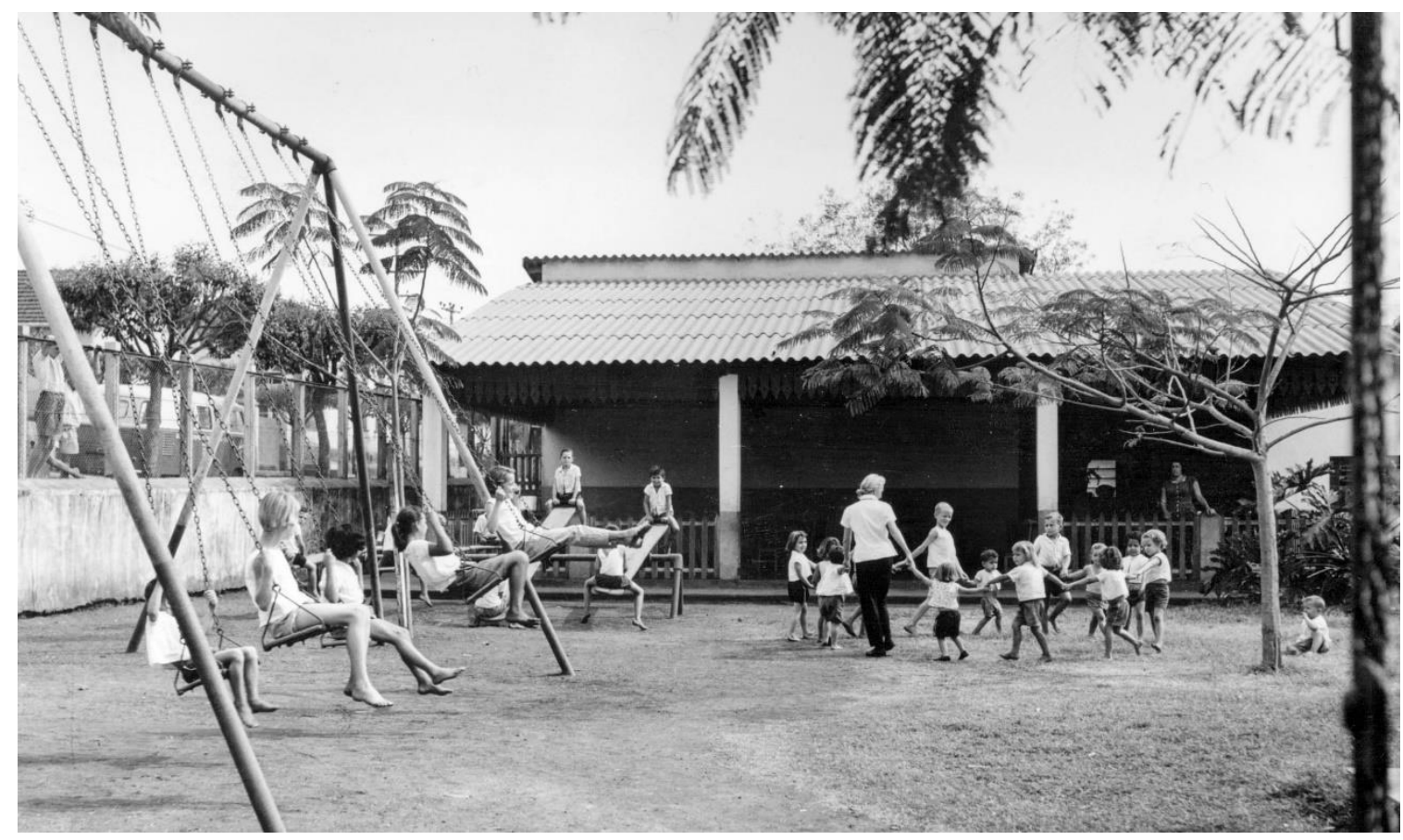

Fonte: Arquivo Público e Histórico de Ribeirão Preto ${ }^{81}$

\footnotetext{
${ }^{81}$ A fotografia pode ser encontrada no Arquivo Público e Histórico de Ribeirão Preto, no fundo Cel. Alfredo
} Condeixa Filho, na Pasta 88, $\mathrm{n}^{\circ}$ de registro 1092. 
Figura 35 - Detalhe da figura 34: pés descalços

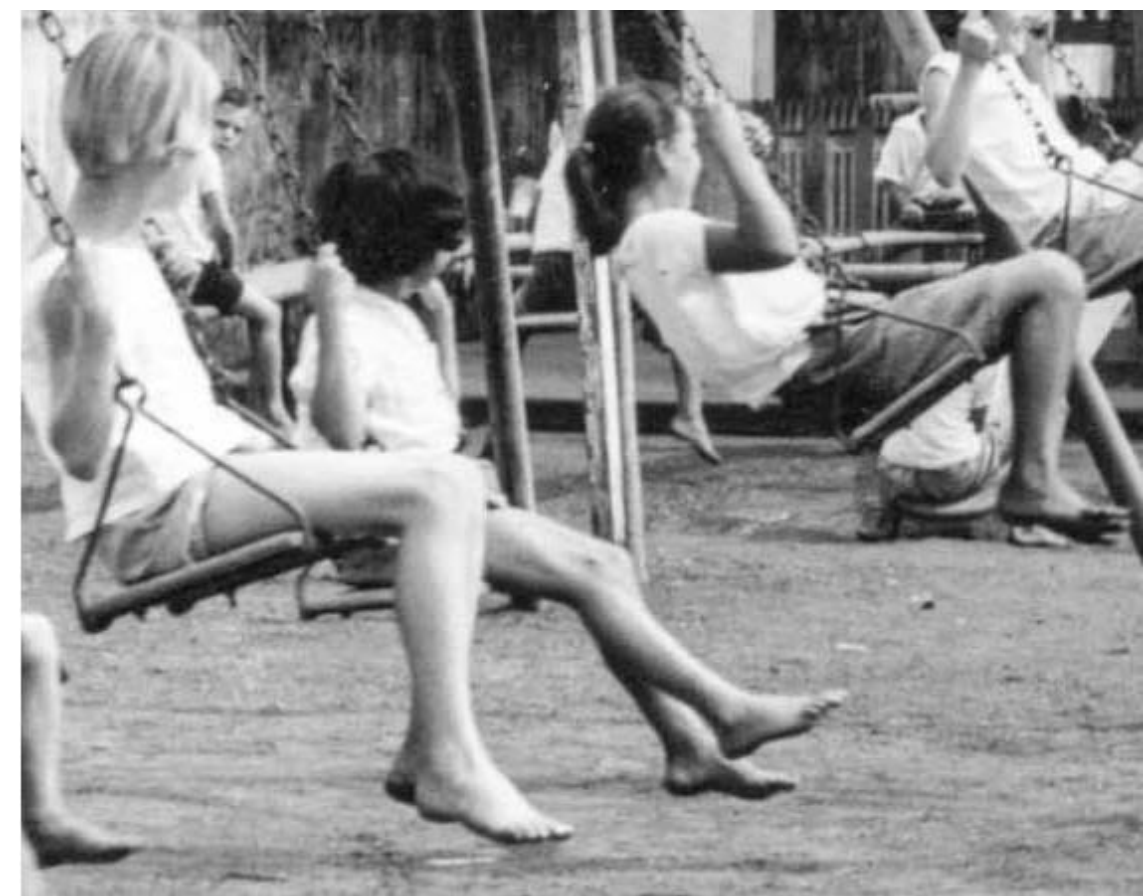

Figura 36 - Parque Infantil Dona Iria Junqueira, setembro de 1961. Foto: Miyasaka

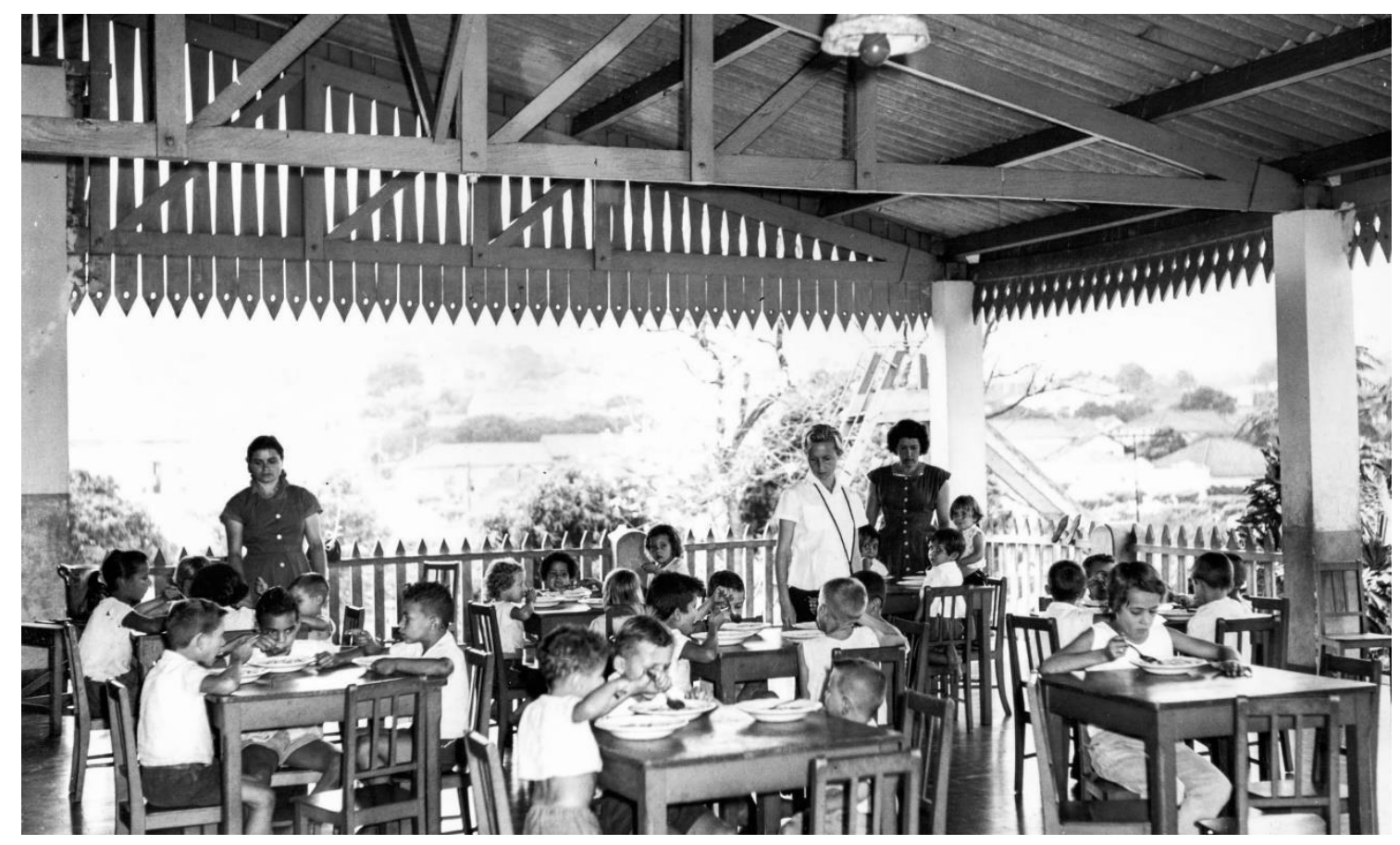

Fonte: Arquivo Público e Histórico de Ribeirão Preto ${ }^{82}$

\footnotetext{
${ }^{82}$ A fotografia pode ser encontrada no Arquivo Público e Histórico de Ribeirão Preto, no fundo Cel. Alfredo
} Condeixa Filho, na Pasta 88, $\mathrm{n}^{\circ}$ de registro 1091. 
Figura 37 - Parque Infantil Dona Iria Junqueira, setembro de 1961. Foto: Miyasaka

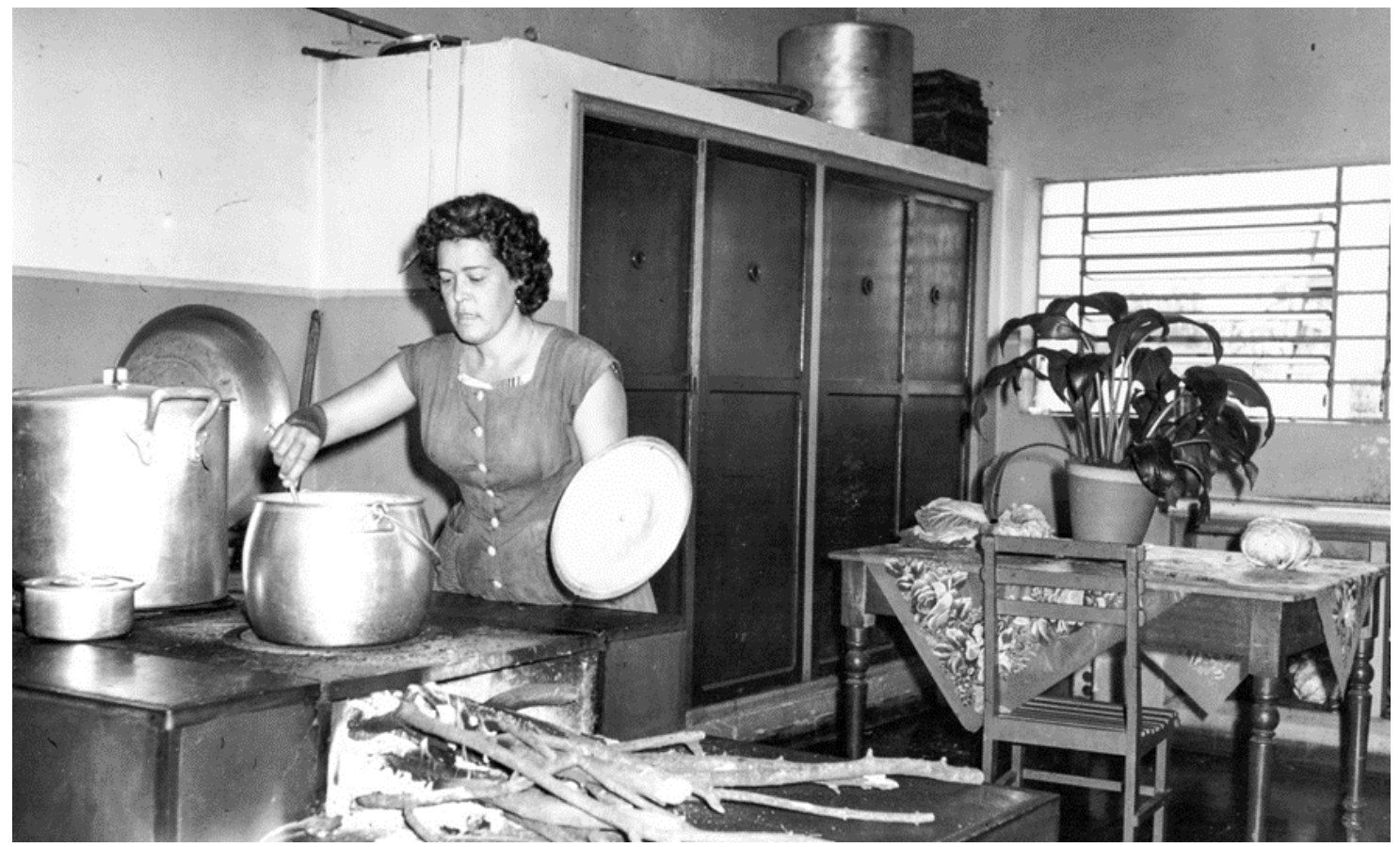

Fonte: Arquivo Público e Histórico de Ribeirão Preto ${ }^{83}$

Atualmente, o parque é a Escola Municipal de Educação Infantil Dona Iria Junqueira. Segundo o histórico da instituição, o parque virou Escola Municipal de Ensino Infantil em de 13 de novembro de 1984, “de acordo com o parecer da CEPG 1793-94 no processo CEE27184, publicado no D.O.M”. (PREFEITURA MUNICIPAL DE RIBEIRÃO PRETO) ${ }^{84}$.

\subsubsection{Parque Infantil de Dumont}

Localização: Rua Santos Dumont, 120 - Dumont ${ }^{85}$.

O Parque Infantil de Dumont foi fundado antes de 1957, pois no projeto de Lei $\mathrm{n}^{\circ} 786 / 59$ (BRASIL, 1959), publicado no Diário Oficial de 07 de maio de 1959, este parque infantil é relacionado como um dos já instalados em Ribeirão Preto nesse período. De acordo com a

\footnotetext{
${ }^{83}$ A fotografia pode ser encontrada no Arquivo Público e Histórico de Ribeirão Preto, no fundo Cel. Alfredo Condeixa Filho, na Pasta 88, $\mathrm{n}^{\circ}$ de registro 1090.

${ }^{84}$ PREFEITURA MUNICIPAL DE RIBEIRÃO PRETO. EMEI Dona Iria Junqueira. Disponível em: <https://www.ribeiraopreto.sp.gov.br/seducacao/escolas/iria/i15iria.php >. Acesso em: 20 maio 2015.

${ }^{85}$ No quadrilátero compreendido entre as Ruas Santos Dumont, Nazareno Fábio, José Bruno Decare e Domingos Lorenzato.
} 
segunda professora contratada para trabalhar no parque da cidade, em 1957, o parque foi inaugurado em 1956 (informação verbal) ${ }^{86}$.

No Arquivo Público e Histórico de Ribeirão Preto há arquivos [caixas] com relatórios de prefeitos e em uma delas consta um Relatório do Governo Municipal de $1957^{87}$, descrevendo que nesse distrito foi inaugurado um "belíssimo Recanto Infantil, com todas as instalações necessárias, que a exemplo dos existentes nos outros Distritos, vem prestando ótima assistência às crianças".

Em setembro de 1961 o fotógrafo Tony Miyasaka foi contratado pela prefeitura da cidade para registrar o cotidiano do Parque Infantil de Dumont (figura 38 a 42). Através de suas fotografias, pode-se notar que o parque tinha um amplo espaço externo para as atividades físicas e recreativas das crianças, com balanços e um grande escorregador. Nota-se também que o galpão do parque era pequeno, simples e que tinha ambulatório médico. Na figura 40, tem-se a vista do salão de refeições do parque, com algumas crianças sentadas à mesa, mas apenas algumas estão comendo, e outras estão sentadas ao fundo, com crianças menores no colo. Na figura 41, há uma fila de crianças segurando canecas para receberem leite ou vitamina, sobre a mesa há um liquidificador, bananas e um coco. A figura 42 apresenta o ambulatório médico do parque, com um garoto sentado sobre uma bancada, recebendo tratamento realizado por um homem, que provavelmente era o enfermeiro do parque.

\footnotetext{
${ }^{86}$ Informação fornecida pela secretária da Educação Elisabeti Lorenzato, via telefone, em outubro de 2014.

${ }^{87} \mathrm{O}$ documento pode ser encontrado no Arquivo Público e Histórico de Ribeirão Preto, na caixa "relatório de prefeitos".
} 
Figura 38 - Parque Infantil de Dumont, setembro de 1961. Foto: Miyasaka

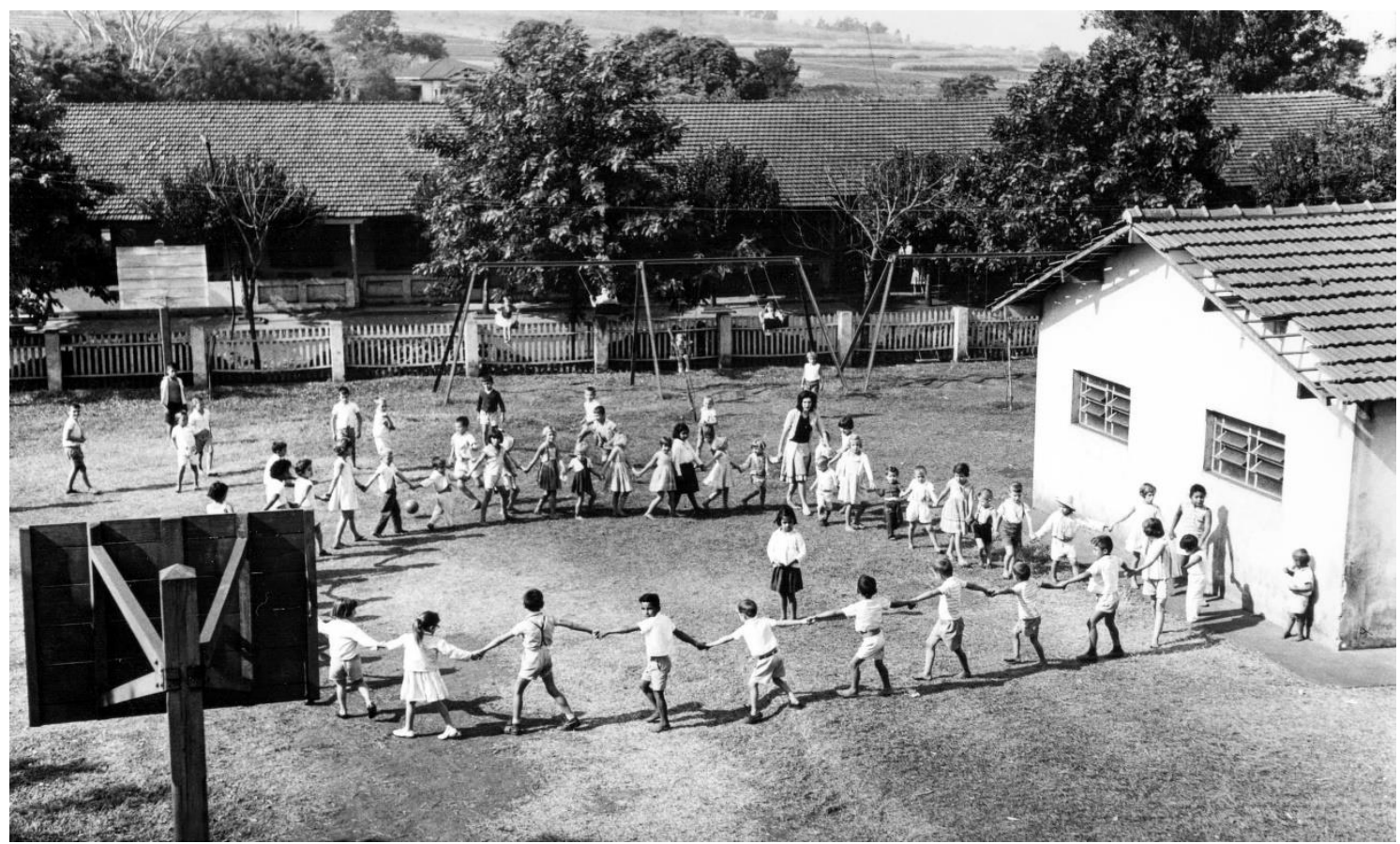

Fonte: Arquivo Público e Histórico de Ribeirão Preto ${ }^{88}$

Figura 39 - Parque Infantil de Dumont, setembro de 1961. Foto: Miyasaka

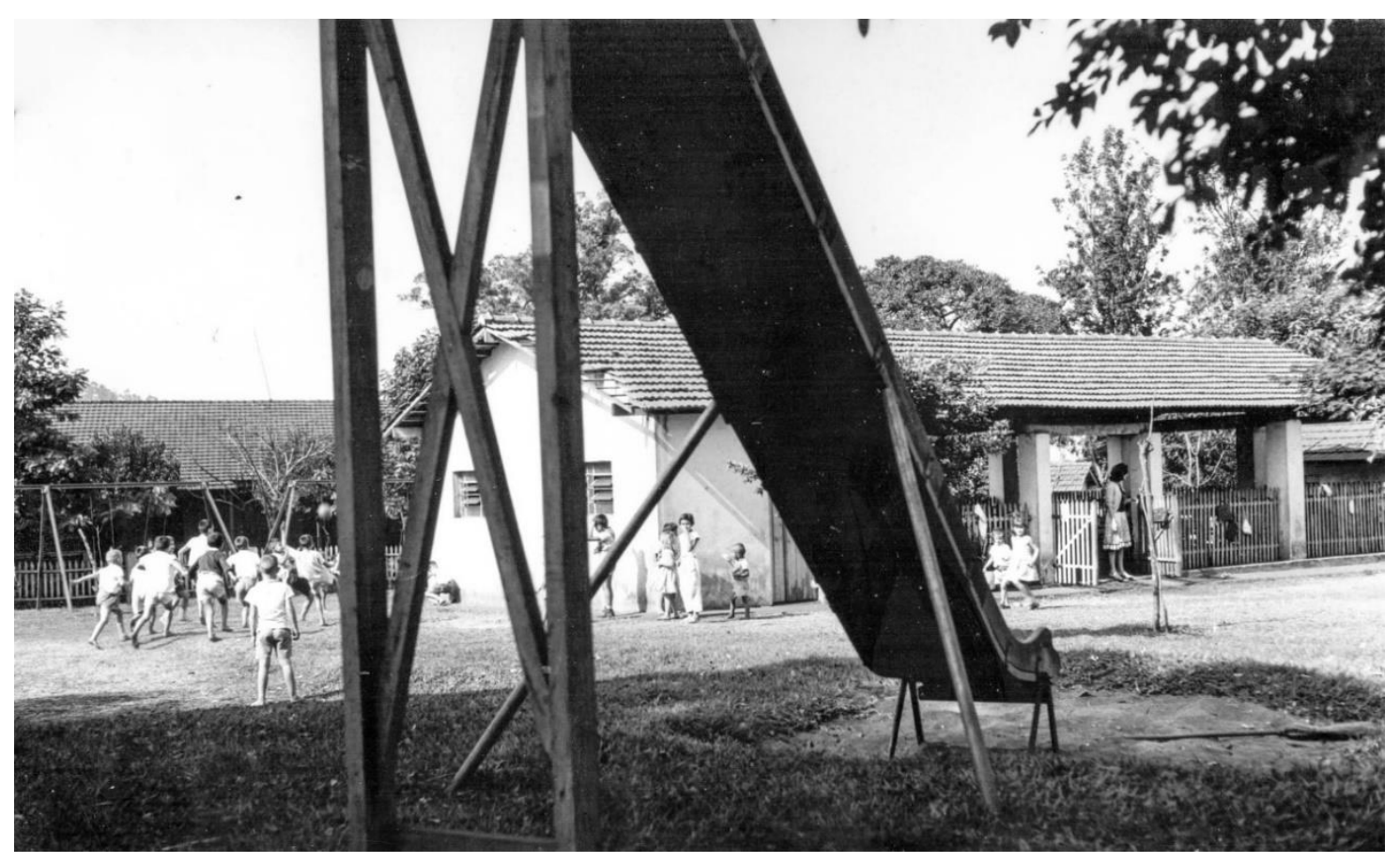

Fonte: Arquivo Público e Histórico de Ribeirão Preto ${ }^{89}$

${ }^{88}$ A fotografia pode ser encontrada no Arquivo Público e Histórico de Ribeirão Preto, no fundo Cel. Alfredo Condeixa Filho, na Pasta 88, $\mathrm{n}^{\circ}$ de registro 1093.

${ }^{89} \mathrm{Ibidem}, \mathrm{n}^{\mathrm{o}}$ de registro 1094. 
Figura 40 - Parque Infantil de Dumont, setembro de 1961. Foto: Miyasaka

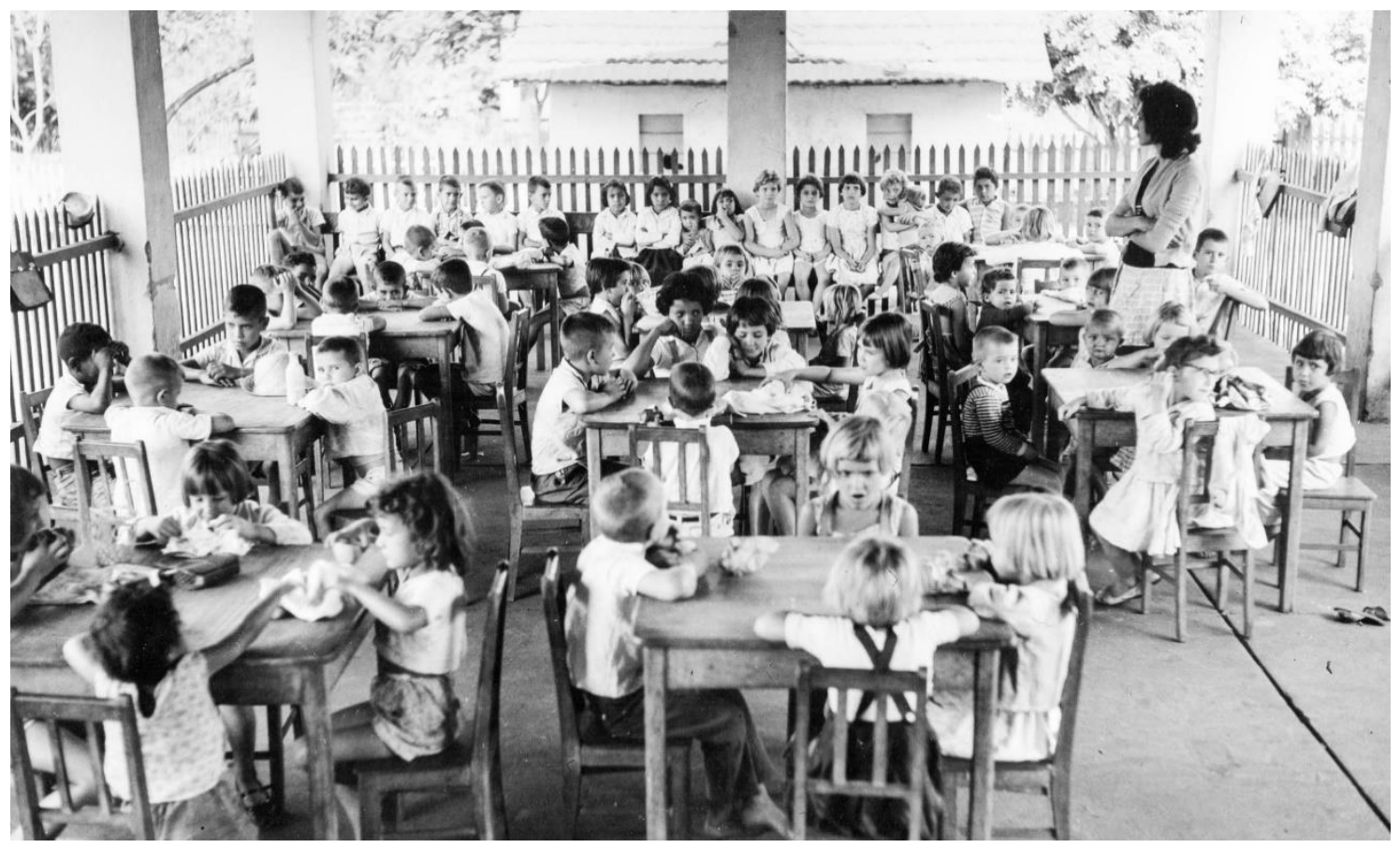

Fonte: Arquivo Público e Histórico de Ribeirão Preto ${ }^{90}$

Figura 41 - Parque Infantil de Dumont, setembro de 1961. Foto: Miyasaka

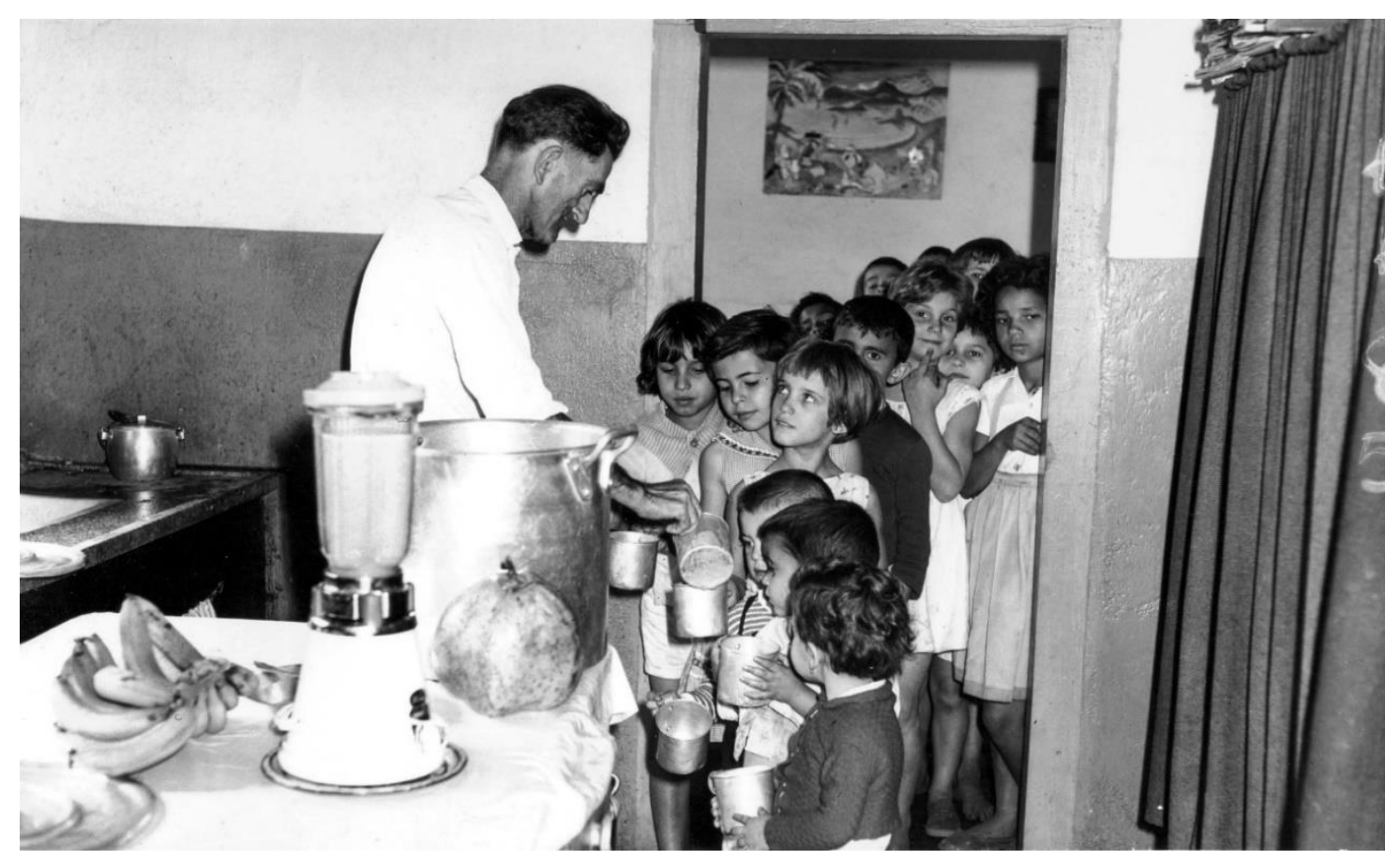

Fonte: Arquivo Público e Histórico de Ribeirão Preto ${ }^{91}$

\footnotetext{
${ }^{90}$ A fotografia pode ser encontrada no Arquivo Público e Histórico de Ribeirão Preto, no fundo JPM, na Pasta $65, \mathrm{n}^{\circ}$ de registro 730 .

${ }^{91}$ A fotografia pode ser encontrada no Arquivo Público e Histórico de Ribeirão Preto, no fundo Cel. Alfredo Condeixa Filho, na Pasta 87, $\mathrm{n}^{\circ}$ de registro 1010.
} 
Figura 42 - Parque Infantil de Dumont, setembro de 1961. Foto: Miyasaka

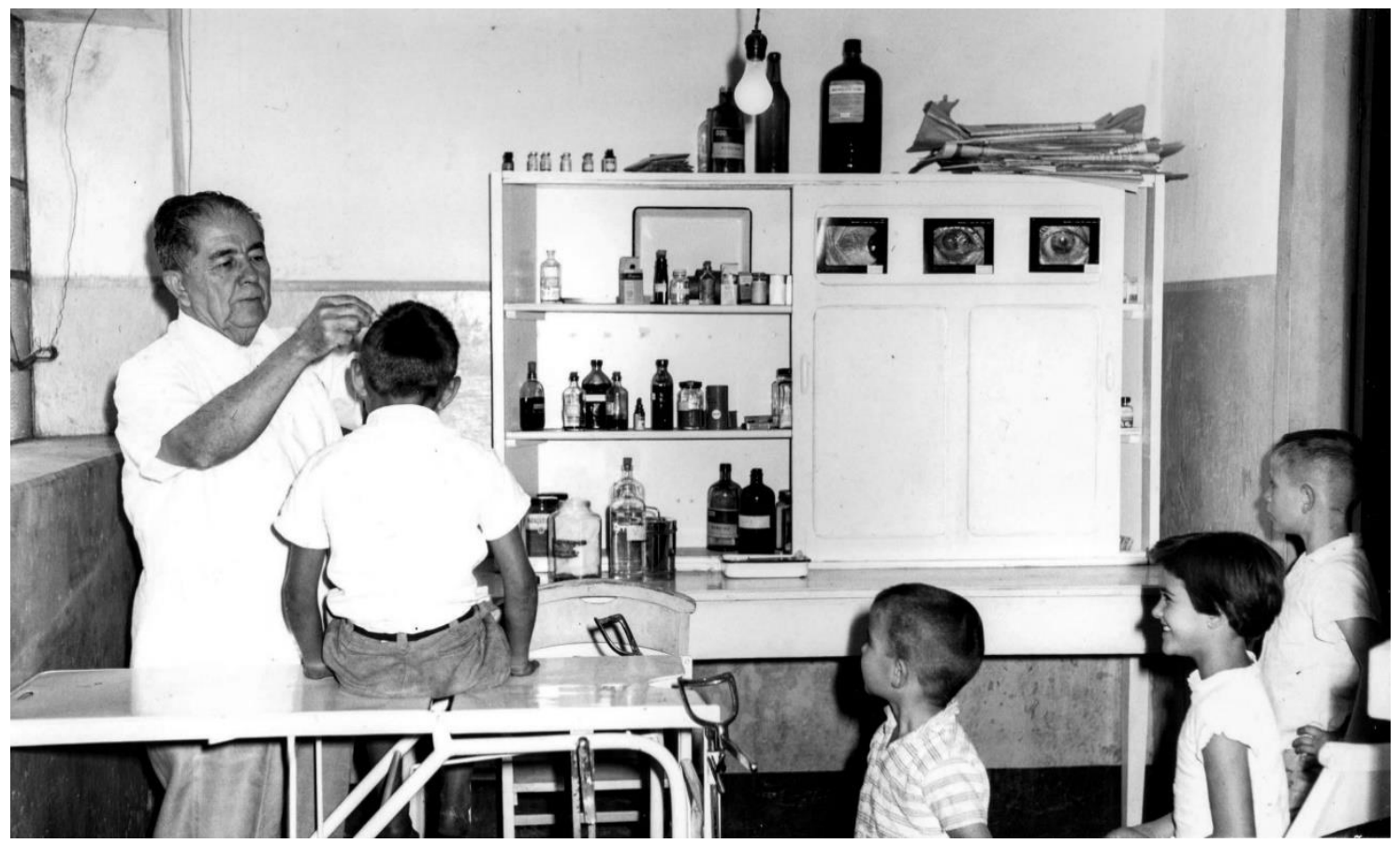

Fonte: Arquivo Público e Histórico de Ribeirão Preto ${ }^{92}$

Há um documento ${ }^{93}$ do Departamento de Educação e Cultura de Ribeirão Preto, de 12 de março de 1965, que contém dados referentes ao número de crianças que frequentavam os parques infantis e escolas municipais da cidade. Consta que já, naquele ano, 1720 crianças frequentaram os parques infantis da região, sendo que 80 delas eram do Parque Infantil de Dumont. O intrigante é que, naquele ano, Dumont já não era mais distrito de Ribeirão Preto, pois, dois anos antes, havia sido assinada a Lei $\mathrm{n}^{\circ}$ 8050, de 31 de dezembro de 1963 (SÃO PAULO, 1963), que transformou o distrito Dumont em município.

Em 15 de fevereiro de 1968, pela Lei $n^{\circ} 114$ (DUMONT, 1968), assinada pelo prefeito de Dumont, Carlos Rosa, o parque infantil da cidade foi denominado Parque Infantil Deputado Costabile Romano, em homenagem ao seu criador.

Até 1996 o Parque Infantil Deputado Costabile Romano era a única instituição que recebia crianças de até 6 anos de idade, ou seja, única instituição de educação infantil municipal. Entretanto, nesse ano foi inaugurada a primeira Escola Municipal de Educação Infantil da cidade, intitulada Professora Olympia Eleusa Decare, que passou a receber também as crianças que frequentavam o parque infantil.

\footnotetext{
${ }^{92}$ A fotografia pode ser encontrada no Arquivo Público e Histórico de Ribeirão Preto, no fundo Cel. Alfredo Condeixa Filho, na Pasta 88, ${ }^{\circ}$ de registro 1095.

${ }^{93} \mathrm{O}$ documento pode ser encontrado no Arquivo Público e Histórico de Ribeirão Preto, no fundo Educação, na Pasta 32, $n^{\circ}$ de registro 357.
} 
De acordo com a atual vice-prefeita de Dumont, Roseane Marin Fernandes Dias (informação verbal) ${ }^{94}$, o parque permaneceu em atividade, mesmo com a inauguração da Escola Municipal de Ensino Infantil Professora Olympia Eleusa Decare, mas, em 2007, o prefeito Antônio Roque Bálsamo demoliu o prédio para a construção de uma praça pública, atualmente conhecida como a Praça do Idoso. Sabe-se que esse ato provocou grande revolta na cidade, pois praticamente toda população adulta da época em que o Parque Infantil Deputado Costabile Romano foi derrubado frequentara o parque quando criança.

Em março de 2015, em comemoração aos 50 anos de Dumont (a Lei de criação da cidade aponta para 1963, mas a cidade comemora em 1965), as escolas municipais realizaram a VI Mostra Pedagógica, intitulada: 50 anos de Dumont - a produção. Nessa mostra, o $2^{\circ}$ ano da Escola Municipal de Educação Fundamental Professor Altino Jacintho Tovo fez uma exposição especial sobre o Parque Infantil Deputado Costabile Romano, com maquetes representando o parque, fotos do arquivo pessoal de ex-professores e ex-alunos e também entrevistas com uma ex-professora do parque. A exposição foi muito comentada na cidade e emocionou ex-alunos, ex-funcionários e ex-professores do Parque Infantil Deputado Costabile Romano.

\subsubsection{Parque Infantil de Guatapará}

Localização: não encontrada.

Há pouquíssimas informações a respeito do Parque de Guatapará. Sabe-se da sua existência devido ao projeto de Lei n ${ }^{\circ} 786 / 59$ (BRASIL, 1959), publicado no Diário Oficial de 07 de maio de 1959, o qual informa que até 1957 Ribeirão Preto tinha 6 parques infantis, entre eles o do distrito de Guatapará.

Além da Lei no 786/59 (BRASIL, 1959), o Relatório do Governo Municipal de $1957^{95}$ informa:

As esferas alcançadas pela esclarecida administração do prefeito municipal Costabile Romano, que, sem favor algum, tem sido uma das mais profícuas de que Ribeirão Preto se ufana, não têm se restringido apenas ao atendimento dos melhoramentos dos serviços públicos do perímetro urbano. Têm alcançado o município, em todos os seus setores, desde o da assistência social, o da remodelação de obras públicas, de vulto até o ensino primário e préprimário dos Distritos. Ainda no ano passado, atendendo às necessidades do Distrito de Guatapará, o prefeito Costabile Romano criou naquela

\footnotetext{
${ }^{94}$ Informação fornecida, via telefone, em maio de 2015.

${ }^{95} \mathrm{O}$ documento pode ser encontrado no Arquivo Público e Histórico de Ribeirão Preto, na caixa "relatório de prefeitos".
} 
localidade um amplo e bem instalado Parque Infantil, proporcionando às crianças daquele distrito um ambiente sadio e alegre, com um serviço de assistência à altura. (RELATÓRIO, 1957, grifo nosso).

\subsubsection{Parque Infantil Santa Maria Goretti}

Localização: Rua Rangel Pestana, 311 - Vila Virgínia.

O Parque Infantil Santa Maria Goretti, primeiramente conhecido como Parque Infantil de Vila Virgínia ou Parque Infantil da Vila Guanabara, começou a ser criado em 10 de março de 1954, quando o prefeito Cel. Alfredo Condeixa Filho abriu crédito especial de Cr\$ 300.000,00 (trezentos mil cruzeiros) para construção desse parque, por meio da Lei ${ }^{\circ} 345$ (RIBEIRÃO PRETO, 1954). Contudo, provisoriamente esse parque serviria para o funcionamento do Grupo Escolar de Vila Virgínia.

No Arquivo Público e Histórico de Ribeirão Preto há dois álbuns, do fundo Cel. Alfredo Condeixa Filho, não intitulados, que apresentam fotografias da construção e inauguração do Parque Infantil de Vila Virgínia quando cedido ao Grupo Escolar, inaugurado pelo Sr. Carlos Teixeira (figura 43, 44 e 45). Pode-se notar que houve uma solenidade de inauguração, a qual contou com apresentação das crianças do Grupo Escolar para as autoridades.

Na figura 45 há 5 fotografias. A fotografia que está ao centro, do prédio do parque, tem uma placa com os seguintes dizeres: "Parque infantil cedido provisoriamente ao Grupo Escolar Meira Júnior. Iniciado em 9-3-1954 e Inaugurado em 19-6-1954”. 
Figura 43 - Álbum 2 - Parque Infantil da Vila Virgínia cedido ao Grupo Escolar

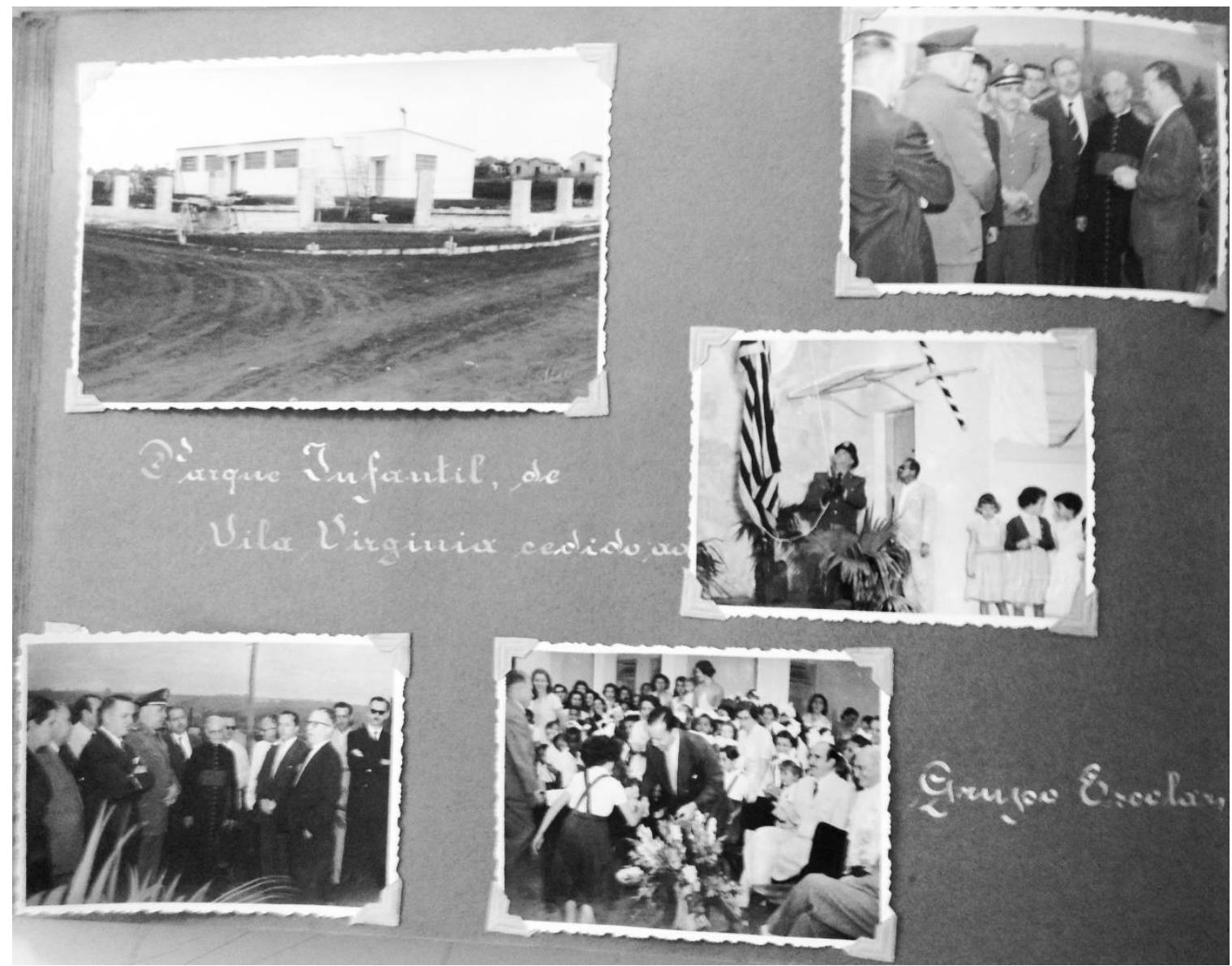

Fonte: Arquivo Público e Histórico de Ribeirão Preto ${ }^{96}$

${ }^{96} \mathrm{O}$ Álbum pode ser encontrado no Arquivo Público e Histórico de Ribeirão Preto, no fundo Cel. Alfredo Condeixa Filho. 
Figura 44 - Álbum 2 - Parque Infantil da Vila Virgínia cedido ao Grupo Escolar

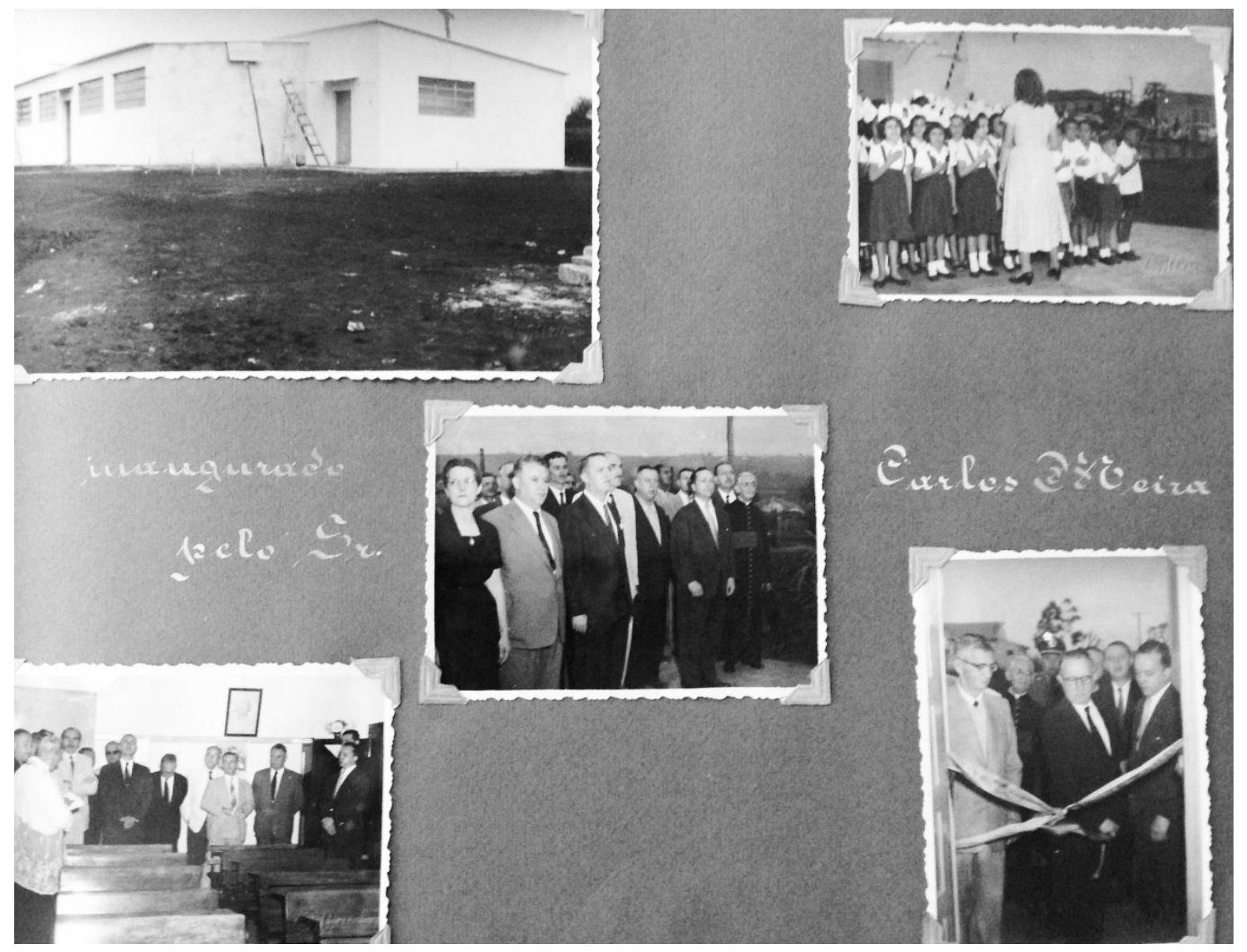

Fonte: Arquivo Público e Histórico de Ribeirão Preto ${ }^{97}$

${ }^{97}$ O Álbum pode ser encontrada no Arquivo Público e Histórico de Ribeirão Preto, no fundo Cel. Alfredo Condeixa Filho. 
Figura 45 - Álbum 3 - Parque Infantil da Vila Virgínia cedido ao Grupo Escolar

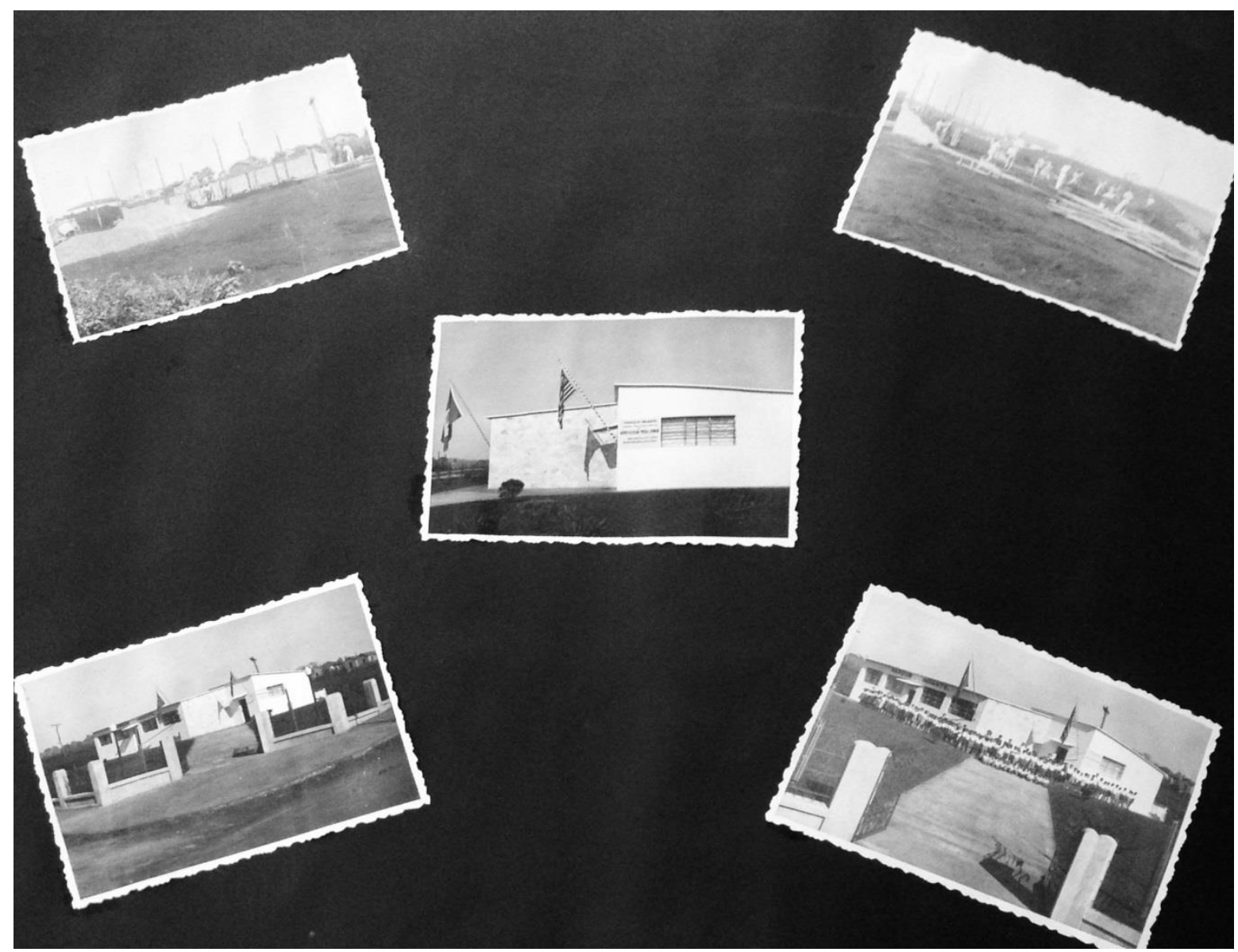

Fonte: Arquivo Público e Histórico de Ribeirão Preto ${ }^{98}$

Em 11 de novembro de 1958 o prefeito Costabile Romano assinou a Lei n 774 (RIBEIRÃO PRETO, 1958b) que criou o Parque Infantil de Vila Virgínia. Após a publicação dessa lei, o Grupo Escolar foi transferido para sua sede própria (um prédio construído na Praça Maria Goretti, no mesmo bairro), deixando de funcionar no prédio do parque infantil do bairro. De acordo com o Diário da Manhã de 14 de novembro de 1958,

[...] foi devolvido à prefeitura o edifício do Parque Infantil da Vila Guanabara e que desde 1954, estava servindo como estabelecimento de ensino.

Agora localizado na esquina das ruas Vital Brasil e Júlio de Mesquita, o $6^{\circ}$ Grupo Escolar 'Meira Júnior', em instalações próprias, melhor atenderá ao crescente progresso daqueles dois bairros operários e dirigida pela professora Otília Figueiredo.

Ao mesmo tempo, com a entrega do prédio à prefeitura, passará a funcionar o 'Parque Infantil' com maior eficiência e servindo centenas de crianças daquela parte de nossa cidade.

\footnotetext{
${ }^{98}$ O Álbum pode ser encontrada no Arquivo Público e Histórico de Ribeirão Preto, no fundo Cel. Alfredo
} Condeixa Filho. 
Já era tempo, também, de se providenciar junto ao Estado, da instalação do Posto de Puericultura da Vila Virgínia a exemplo dos que existem na cidade e nos bairros da Vila Tibério, Barracão e Campos Elíseos. (DIÁRIO DA MANHÃ, 1958).

De acordo com o Fundo "Escolas Municipais" da Secretaria de Planejamento da cidade, o parque foi inaugurado em 05 de janeiro de 1959. Em 06 de março no mesmo ano, quatro meses após a lei de criação do parque, o mesmo prefeito assinou a Lei no 820 (RIBEIRÃO PRETO, 1959a) que o denomina de "Santa Maria Goretti" e, em 18 de setembro, o prefeito Áureo Norberto da Silva assinou a Lei no 857 (RIBEIRÃO PRETO, 1959b) autorizando a construção de uma piscina nesse parque.

Em 10 de abril de 1959 o jornal A Cidade publicou uma nota sobre os movimentos dos parques infantis de março de 1959 e consta que 16577 refeições foram fornecidas às crianças naquele mês; que ocorreram 413 tratamentos dentários; e 44 cortes de cabelos foram realizados.

Em setembro de 1961, o fotógrafo Tony Miyasaka fotografou o Parque Infantil Santa Maria Goretti e somente as suas fotos revelam como era esse parque infantil (figuras 46, 47 e 48). A figura 46 apresenta a vista do prédio, o jardim, um grupo de professoras em uma das portas do prédio e três crianças, uma ao lado do grupo de professoras, outra encostada na parede do prédio e outra sentada no chão perto da outra porta. Já a figura 47 tem à vista grande grupo de alunos do parque, professoras e funcionários (4 homens e 11 mulheres) posicionados na lateral do prédio do parque e a figura 48 apresenta uma visão superior do escorregador com as crianças em atividades recreativas. 
Figura 46 - Parque Infantil Santa Maria Goretti, setembro de 1961. Foto: Miyasaka

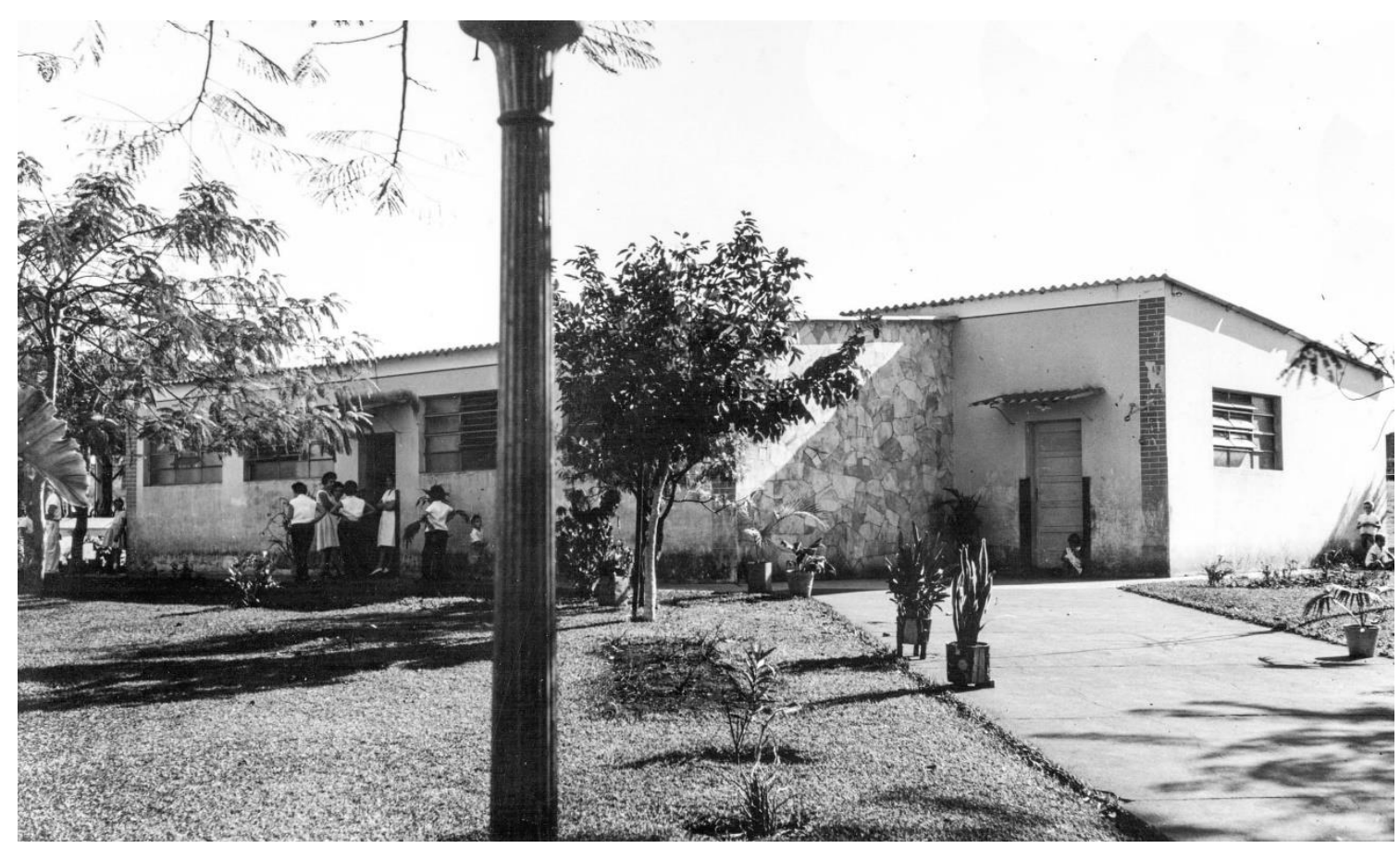

Fonte: Arquivo Público e Histórico de Ribeirão Preto ${ }^{99}$

Figura 47 - Parque Infantil Santa Maria Goretti, setembro de 1961. Foto: Miyasaka

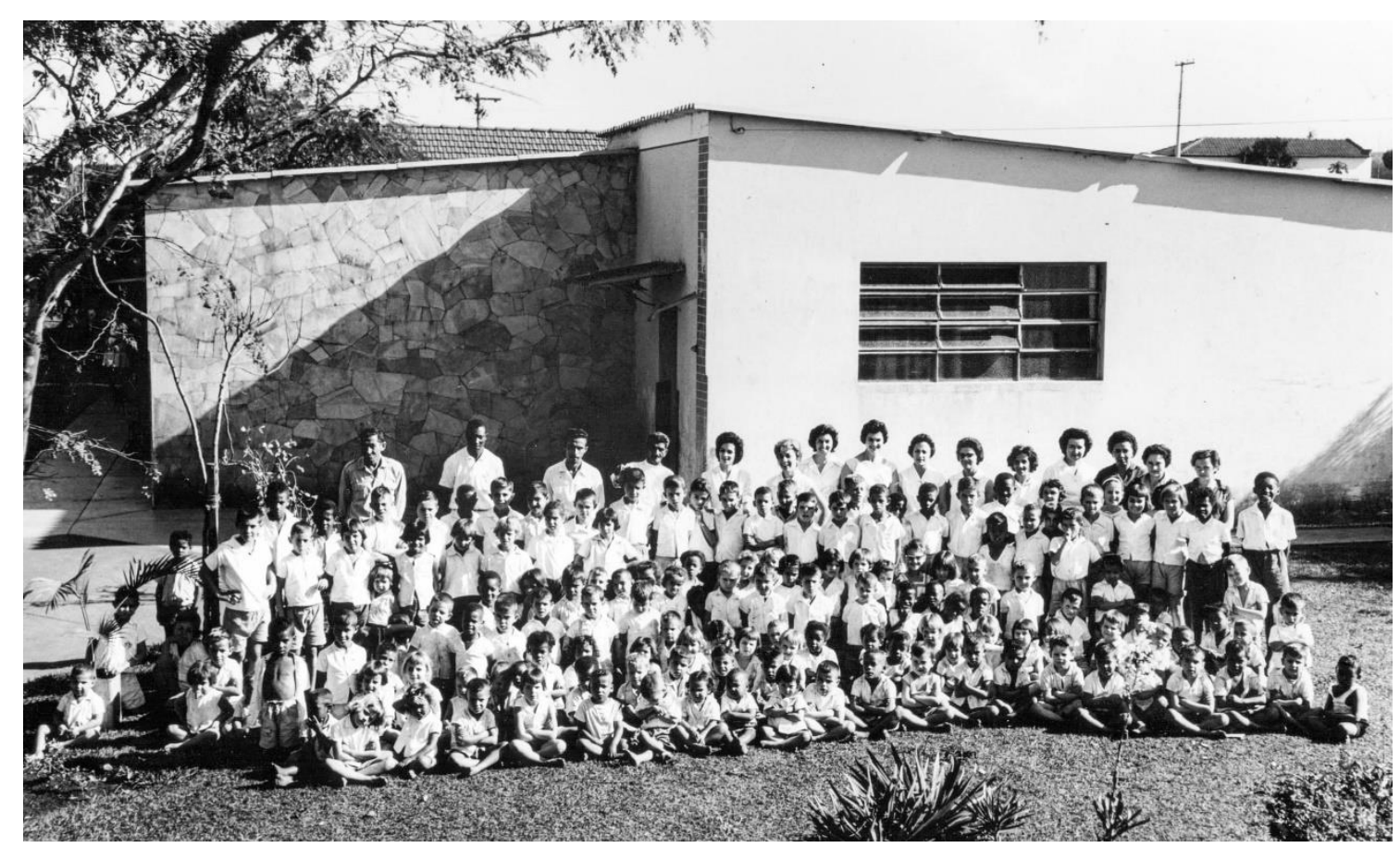

Fonte: Arquivo Público e Histórico de Ribeirão Preto ${ }^{100}$

${ }^{99}$ A fotografia pode ser encontrada no Arquivo Público e Histórico de Ribeirão Preto, no fundo Cel. Alfredo Condeixa Filho, na Pasta 88, $\mathrm{n}^{\circ}$ de registro 1096.

${ }^{100}$ Ibidem, $\mathrm{n}^{\circ}$ de registro 1099 . 
Figura 48 - Parque Infantil Santa Maria Goretti, setembro de 1961. Foto: Miyasaka

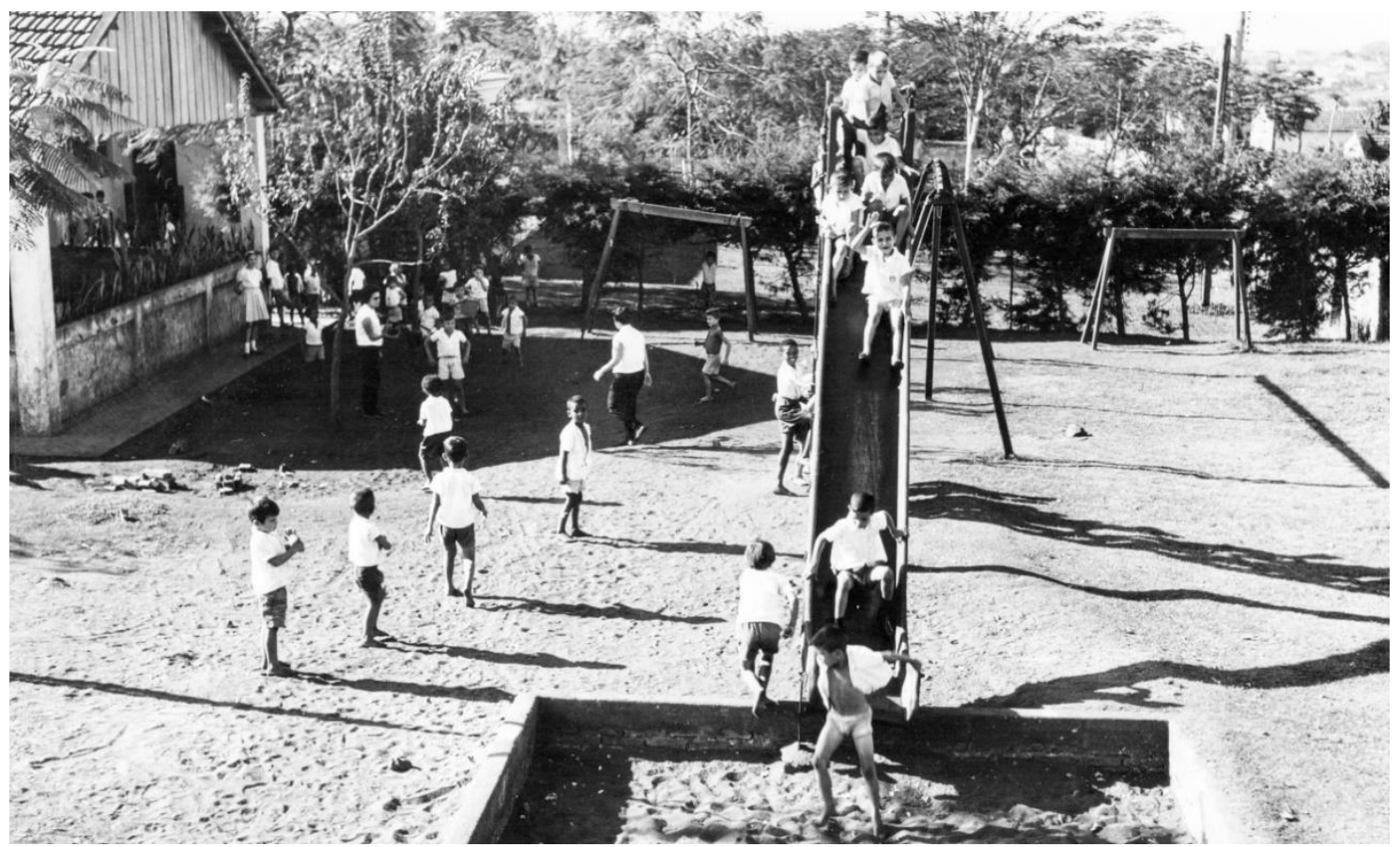

Fonte: Arquivo Público e Histórico de Ribeirão Preto ${ }^{101}$

Nota-se, na figura 48, que praticamente todas crianças estavam descalças, característica das crianças de origem humilde. Um artigo publicado pelo jornal Diário da Manhã, de 28 de agosto de 1962, apoiava uma campanha de roupas e calçados para as crianças do parque e informava sobre as ações que estavam ocorrendo naquela semana:

Na manhã de ontem, levados pelo caminhão da prefeitura dos parques infantis, com dois contínuos e duas professoras, estiveram no Aeroporto Leite Lopes, 40 crianças de 4 e 5 anos de idade, do Parque Infantil da Vila Virgínia.

Poucas, raríssimas mesmo, com calçado e a maioria de roupas sumárias.

A reportagem teve ocasião de ouvir as professoras que nos disseram que agora está fazendo obra de recuperação, pois é gente pobre humilde mesmo, tendo chegado ao parque em situação difícil.

Com a assistência inicial, médica, farmacêutica, dentária e agora com a piscina, a par da sopa que é dada todos os dias, em um mês houve modificação geral, graças aos cuidados que a prefeitura vem dispensando, embora não possa realizar mais do que está no orçamento.

Há que se apelar, pois, para as entidades locais, em promoção para se obter calçados e roupas para as 300 crianças do Parque Infantil da Vila Virgínia.

Mister se faz uma visita ao local e ali verificar o que já se fez em tão curto prazo, assim como se promove meios para calçar e vestir aquele exército mirim, oriundo de pais humildes, pedreiros, cozinheiras, lavadeiras, gente simples, ganhando salário mínimo e sem ter possibilidades para dar aos filhos um melhor padrão de vida. (DIÁRIO DA MÃNHÃ, 1962).

${ }^{101}$ A fotografia pode ser encontrada no Arquivo Público e Histórico de Ribeirão Preto, no fundo Cel. Alfredo Condeixa Filho, na Pasta 88, nº de registro 1098. 
Em 30 de setembro de 1962 o jornal Diário da Manhã publicou uma reportagem intitulada: "Desapareceu o espetáculo doloroso da falta de água na cidade e nos bairros graças aos métodos racionais empregados pela administração Condeixa Filho". Nessa reportagem a piscina construída, apenas naquele ano, no Parque Infantil Santa Maria Goretti é mencionada e retratada (figura 49) como uma piscina idêntica às outras já existentes nos demais parques da cidade.

Figura 49 - Parque Infantil Santa Maria Goretti - piscina

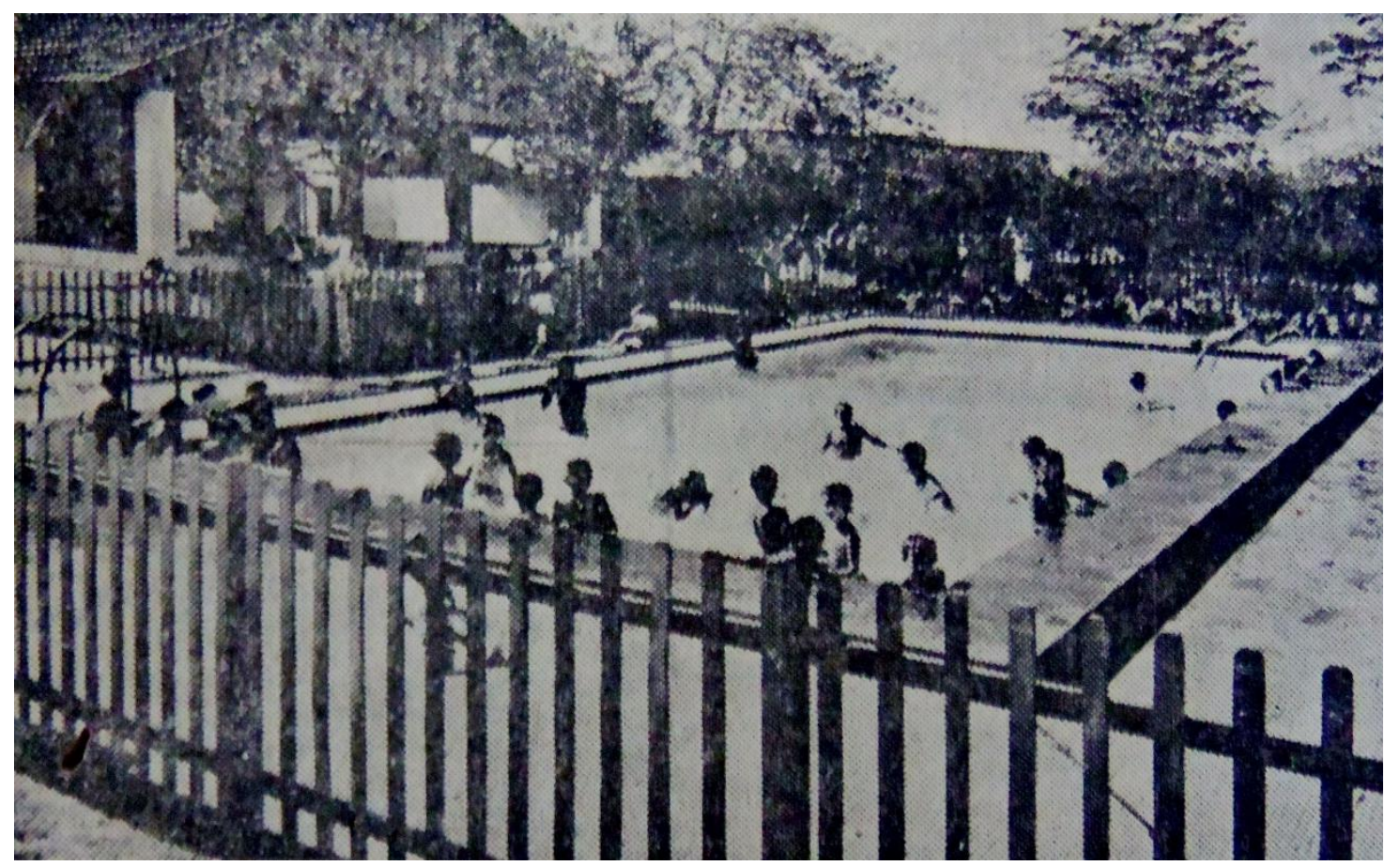

Fonte: DIÁRIO DA MANHÃ, 1962

Em 30 de abril de 1963 o jornal Diário da Manhã informou que haviam sido iniciadas por uma equipe da Faculdade de Medicina, sob orientação do professor José Oliveira de Almeida, pesquisas no Parque Infantil Santa Maria Goretti. Essas pesquisas começaram com a coleta de sangue para os primeiros exames sobre a incidência de moléstia de Chagas, sífilis, entre outras e, além disso, fizeram uma avaliação do grau de nutrição das crianças. Informaram ainda que todos os dados obtidos durante as pesquisas seriam tabulados e servidos para posteriores providências. Entretanto, não foram encontrados os resultados desses estudos.

Há um documento ${ }^{102}$ no Arquivo Público e Histórico de Ribeirão Preto informando que em 1965 cerca de 300 crianças ainda frequentavam o Parque Infantil Santa Maria Goretti.

\footnotetext{
${ }^{102} \mathrm{O}$ documento pode ser encontrado no Arquivo Público e Histórico de Ribeirão Preto, no fundo Educação, na Pasta $32, n^{\circ}$ de registro 357.
} 
Em 05 de maio de 1966, o jornal Diário da Manhã divulgou que, no dia seguinte, o prefeito Dr. Welson Gasparini iria inaugurar às 15h mais uma Escola Vocacional Parqueana, instalada no Parque Infantil Maria Goretti, que tinha, como visão, dar às crianças uma formação vocacional completa. No dia 08 de maio o mesmo jornal publicou sobre a inauguração e relatou que a Escola Vocacional Parqueana já estava funcionando desde o início do ano escolar.

Em 17 de agosto de 1978, o jornal A Cidade, publicou que o bairro Vila Virgínia era praticamente o berço de uma outra cidade em Ribeirão Preto e destacaram o Parque Infantil Santa Maria Goretti como o local de maior assistência social do bairro:

No Parque Infantil Santa Maria Goretti, por exemplo, com 400 crianças matriculadas, 10 professores mantidos pela prefeitura municipal assistem a educação dessas crianças de 3 a 9 anos. $O$ parque funciona das 8 às 16h, diariamente, menos aos sábados, porque pesquisas realizadas comprovaram que $99 \%$ das crianças não vão à escola nesse dia. Além do Parque Infantil propriamente dito, funciona no local uma classe para ensino de $1^{\circ}$ Grau e outras duas de pré-primário. (A CIDADE, 1978).

Em 1 de outubro de 1980, por meio da Lei no 3839 (RIBEIRÃO PRETO, 1980a) assinada pelo prefeito Dr. Antônio Duarte Nogueira, o parque se tornou Escola Básica de $1^{\circ}$ Grau "Maria Goretti” e em 1985, através da Lei no 4696 (RIBEIRÃO PRETO, 1985), se transformou em Escola Municipal de Ensino Infantil Maria Goretti.

\subsubsection{Parque Infantil dos Bandeirantes}

Localização: Rua General Câmara, 1387 - Ipiranga.

De acordo com o Decreto $n^{\circ}$ 004, de 05 de fevereiro de 1963, o parque infantil na Vila Recreio $^{103}$ foi construído no começo de 1963 e o prefeito Cel. Alfredo Condeixa Filho o denomina Parque Infantil dos Bandeirantes, como homenagem aos desbravadores do interior do Brasil:

Considerando que os Bandeirantes Paulistas foram os desbravadores dos setores brasileiros e pioneiros da civilização do interior;

Considerando que o Parque Infantil, recém-construído na Vila Recreio, qual Bandeirante, se instala num dos bairros mais afastados de Ribeirão Preto, para até levar o progresso. (RIBEIRÃO PRETO, 1963a).

${ }^{103}$ Na década de 1960 o bairro Vila Recreio é o que atualmente /representa-se como o subsetor N-2. 
Ainda no mês de fevereiro, o prefeito Cel. Alfredo Condeixa Filho, a partir do Decreto nº 010 (RIBEIRÃO PRETO, 1963b), oficializou que a Escola Municipal Professora Conceição Monteiro de Barros, que funcionava sem cunho oficial há alguns anos no bairro do Barracão, passaria a funcionar nas salas do prédio do Parque Infantil dos Bandeirantes. Entretanto, apesar de se saber que a Escola foi criada e inaugurada, não foi encontrada nenhuma informação sobre o que aconteceu com esta escola municipal. Além disso, não foi encontrada a planta desse parque, o que permitiria compreender sobre a existência dessas salas de aula, pois a proposta dos parques infantis era que tivesse apenas um galpão com vestiário feminino; vestiário masculino; ambulatório médico; consultório odontológico; copa; dispensa; depósito; sala dos professores; e uma área coberta.

A lei de criação do parque, $n^{\circ} 1291$ (RIBEIRÃO PRETO, 1963d), foi assinada pelo prefeito Cel. Alfredo Condeixa Filho no dia 08 de abril do mesmo ano e sua inauguração ocorreu as 8h30 no dia 12 de maio de 1963, de acordo com o jornal Diário da Manhã daquele mesmo dia, para atender as crianças daquele bairro de trabalhadores.

De acordo com o Diário da Manhã de 11 de maio de 1963 (um dia antes da inauguração):

Outra homenagem às mães será prestada pela Prefeitura Municipal, amanhã, Dia da Rainha do Lar, com a inauguração do Parque Infantil dos Bandeirantes, na Vila Recreio, às 8,30 horas. Antecedendo o ato inaugural, dom Agnelo Rossi, arcebispo metropolitano, celebrará missa em ação de graças e por intenção de todas as mães ribeirão-pretanas e da arquidiocese de Ribeirão Preto. Também para essas solenidades são convidados as autoridades e o povo em geral. (DIÁRIO DA MANHÃ, 1963).

As figuras 50, 51 e 52 foram tiradas por Tony Miyasaka no dia da inauguração do parque. A figura 50 mostra Dom Agnelo Rossi descerrando a fita de inauguração do parque. Ao seu lado estão o prefeito Cel. Alfredo Condeixa Filho, um repórter que segura um microfone nas mãos e população. A figura 51 exibia vista da fachada do prédio e grande número de pessoas durante solenidade de inauguração e a figura 52 também mostra a vista do prédio e grande número de crianças durante solenidade de inauguração, entretanto, já exibe as crianças e garotos sobre o escorregador do parque. O interessante dessa imagem é que tem um enquadramento do ponto de vista diagonal, o que permite ampliar a visão do parque. 
Figura 50 - Inauguração do Parque Infantil dos Bandeirantes, maio de 1963. Foto: Miyasaka

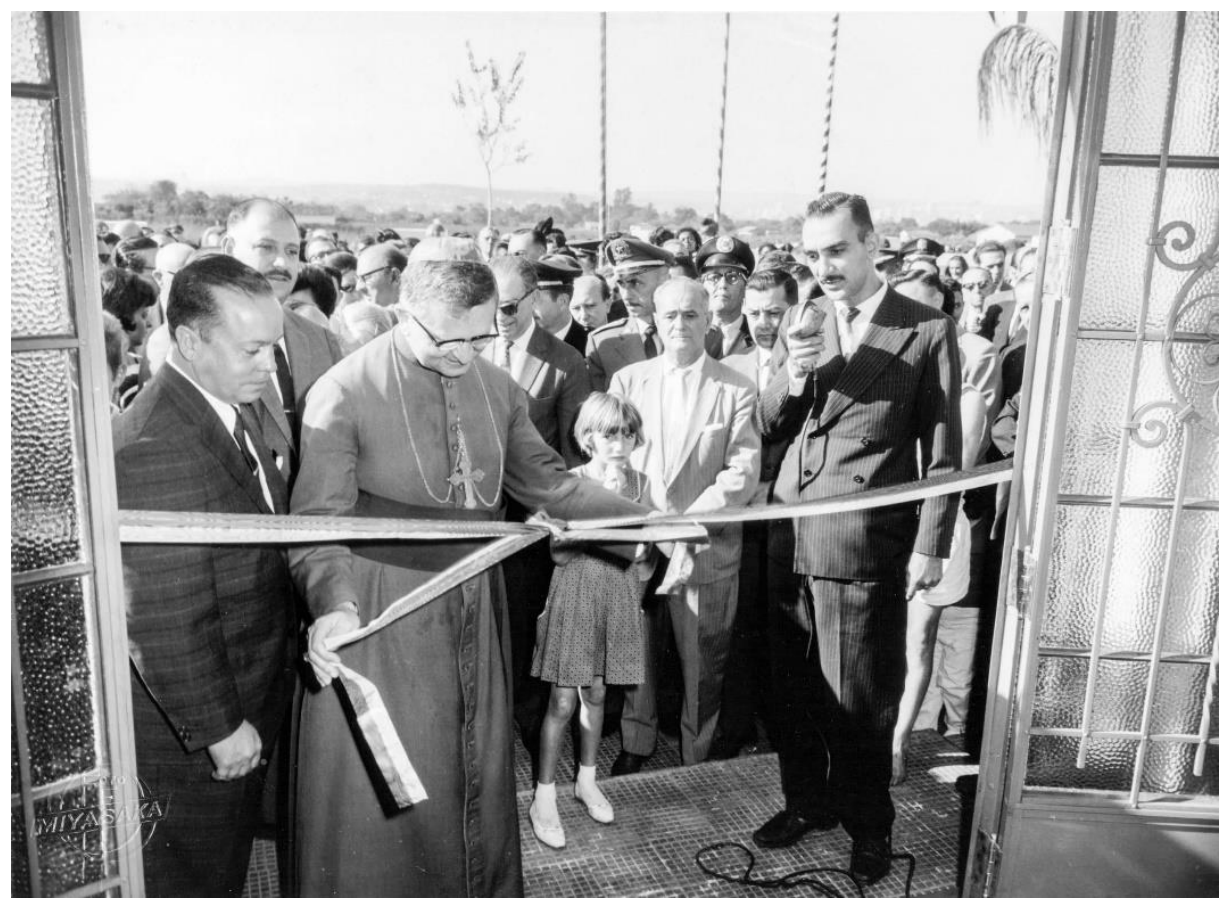

Fonte: Arquivo Público e Histórico de Ribeirão Preto ${ }^{104}$

Figura 51 - Inauguração do Parque Infantil dos Bandeirantes, maio de 1963. Foto: Miyasaka

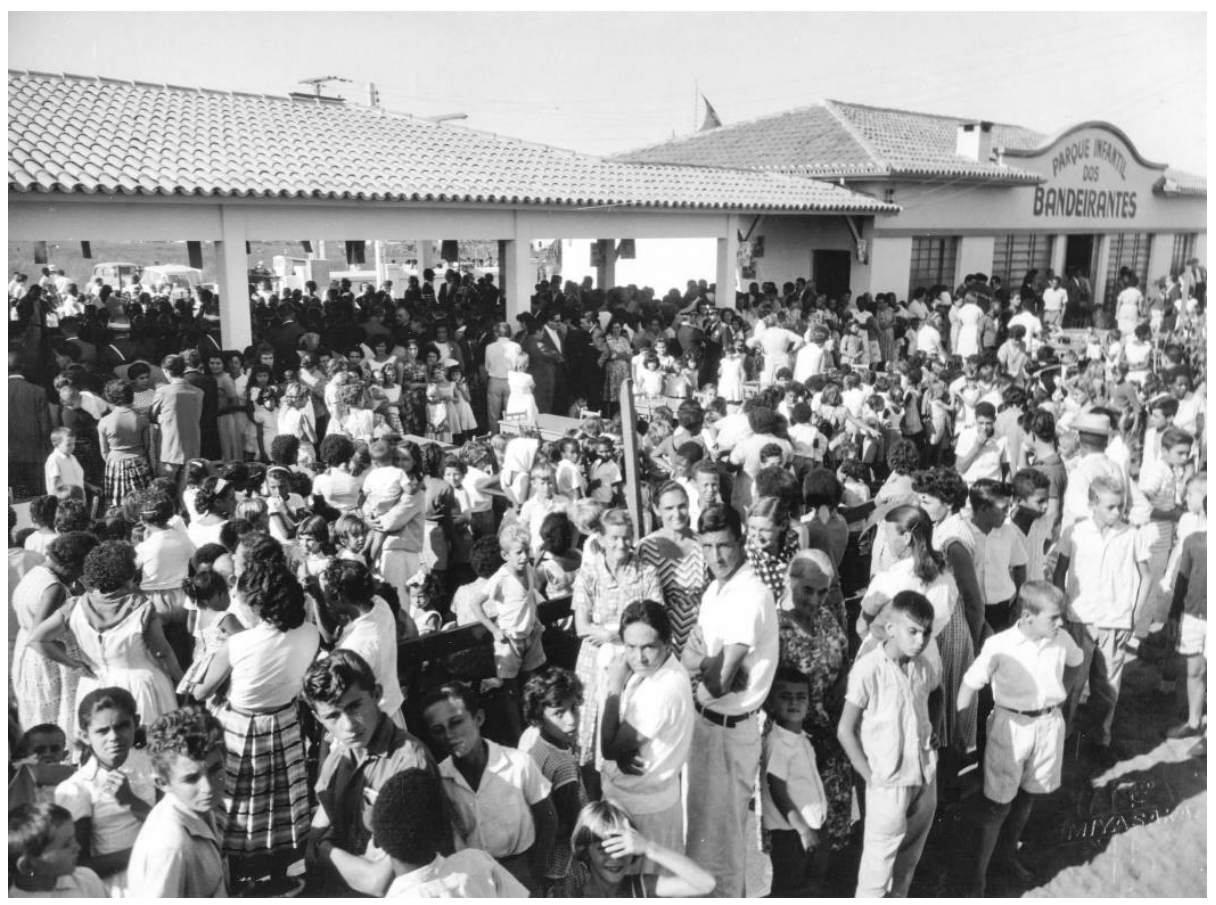

Fonte: Arquivo Público e Histórico de Ribeirão Preto ${ }^{105}$

${ }^{104}$ A fotografia pode ser encontrada no Arquivo Público e Histórico de Ribeirão Preto, no fundo Cel. Alfredo Condeixa Filho, na Pasta 88, ${ }^{\circ}$ de registro 1102.

105 Ibidem, $\mathrm{n}^{\mathrm{o}}$ de registro 1104. 
Figura 52 - Inauguração do Parque Infantil dos Bandeirantes, maio de 1963. Foto: Miyasaka

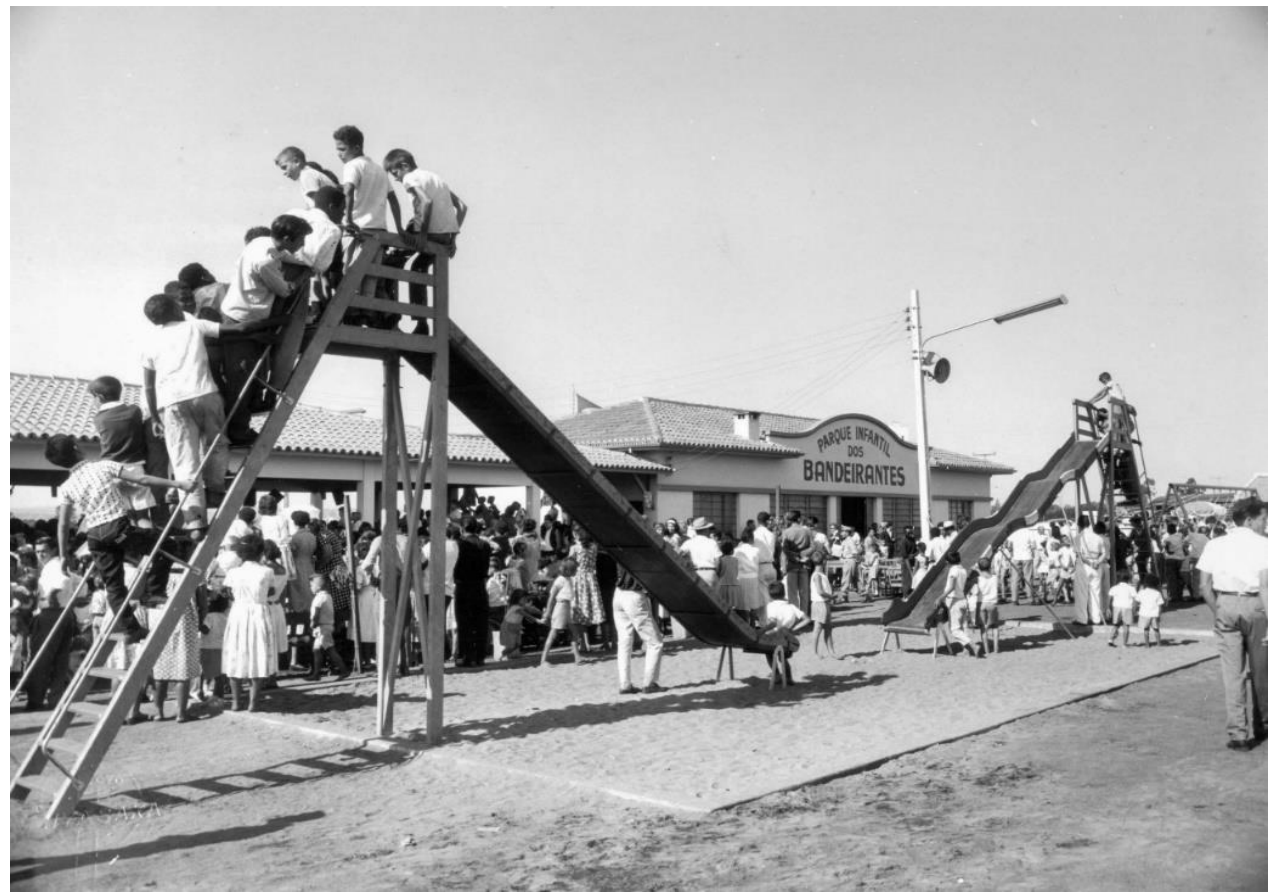

Fonte: Arquivo Público e Histórico de Ribeirão Preto ${ }^{106}$

Dois dias após a inauguração do parque, o jornal Diário da Manhã publicou que o evento contou com a presença de "autoridades civis, militares e eclesiásticas e destacados elementos de nossa cidade", informou também que o diretor do Hospital das Clínicas e o diretor da Companhia Comércio e Indústria Antônio Diederichsen foram os paraninfos do consultório médico e do gabinete dentário do parque. O evento contou também com a presença do ministro da Educação, Teotônio Monteiro de Barros, pois a Escola Municipal Professora Conceição Monteiro de Barros também foi inaugurada naquele dia. Ao final da reunião de abertura da solenidade, as autoridades se dirigiram para o galpão de festas do Parque Infantil, onde "teve lugar um programa lítero-musical, com o concurso de grupos dos diversos parques infantis da cidade" como pode-se ver na figura 53 .

\footnotetext{
${ }^{106}$ A fotografia pode ser encontrada no Arquivo Público e Histórico de Ribeirão Preto, no fundo Cel. Alfredo Condeixa Filho, na Pasta 88, $\mathrm{n}^{\circ}$ de registro 1110.
} 
Figura 53 - Inauguração do Parque Infantil dos Bandeirantes, maio de 1963. Foto: Miyasaka

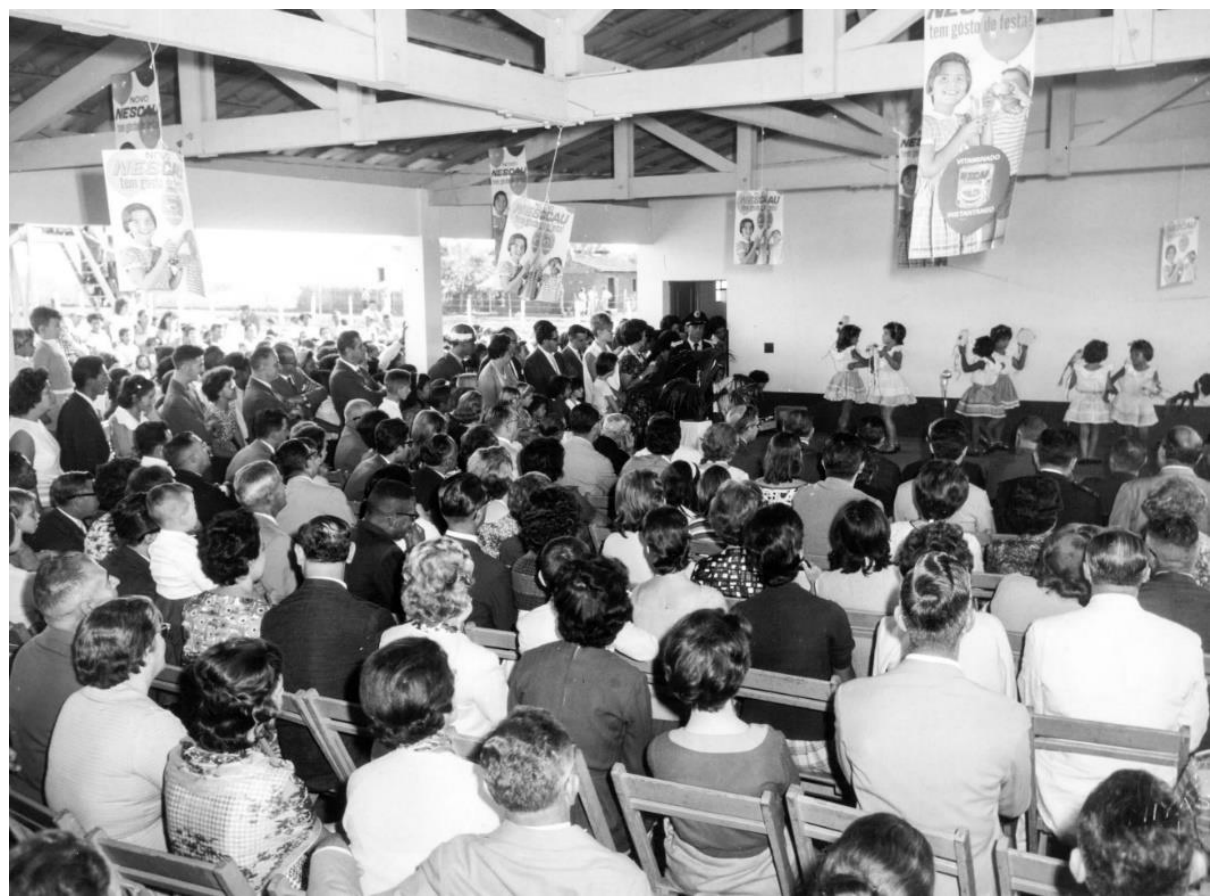

Fonte: Arquivo Público e Histórico de Ribeirão Preto ${ }^{107}$

Dois anos após a inauguração, foram realizados festejos em comemoração aos 2 anos de parque. De acordo com o jornal Diário da Manhã, de 12 de maio de 1965:

A professora Yara Maria Babosa, diretora do modelar estabelecimento educacional da Prefeitura Municipal, programou uma série de acontecimentos festivos, devendo tomar parte dos mesmos os parqueanos, familiares, autoridades locais e moradores das imediações.

Um almoço especial será servido aos presentes, após teremos uma sessão de números recreativos a cargo das crianças, bem como algumas competições esportivas infantis. (DIÁRIO DA MANHÃ, 1965).

Percebe-se que o parque seguia o modelo proposto pelos parques pioneiros da cidade, com festejos, competições e recreações. Contudo, sua fachada demonstra que, em relação às instalações, este destoava dos outros parques, uma vez que há um amplo espaço interno para as crianças. Analisando a figura 54 vemos a fachada do prédio, muro e o portão de entrada. Podese dizer que sua arquitetura tem um frontão que fica entre o neobarroco e o neocolonial, mas extremamente simplificado, ou seja, parece uma tímida tentativa de dar um estilo a um prédio utilitário que não tinha pretensões arquitetônicas maiores, se é que tinha alguma em seu projeto (o qual não foi encontrado).

\footnotetext{
${ }^{107}$ A fotografia pode ser encontrada no Arquivo Público e Histórico de Ribeirão Preto, no fundo Cel. Alfredo Condeixa Filho, na Pasta 88, $\mathrm{n}^{\circ}$ de registro 1106.
} 
Figura 54 - Parque Infantil dos Bandeirantes, maio de 1963. Foto: Miyasaka

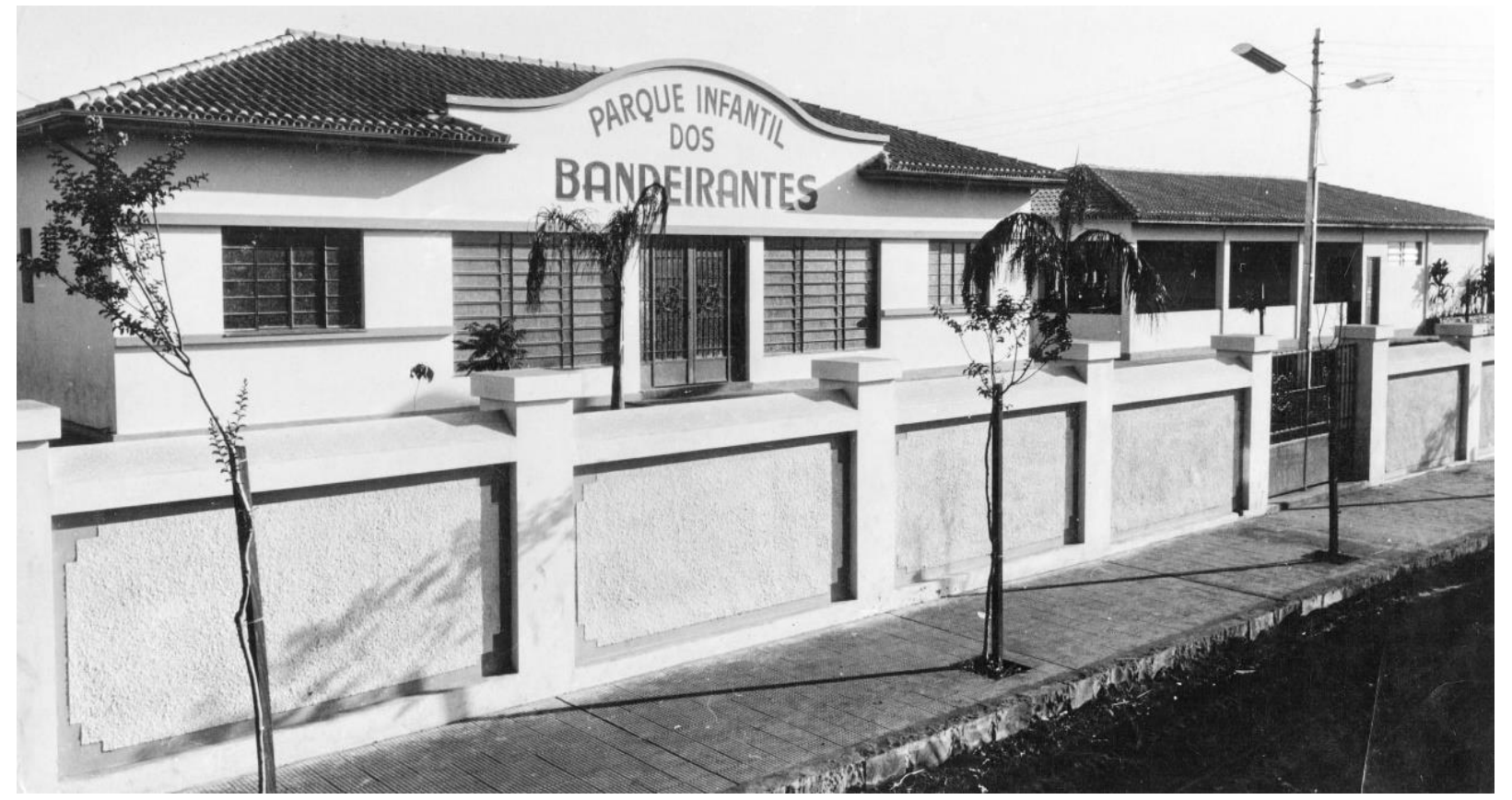

Fonte: Arquivo Público e Histórico de Ribeirão Preto ${ }^{108}$

Em 11 de abril de 1966, foi inaugurada, no Parque Infantil dos Bandeirantes, pelo prefeito Dr. Welson Gasparini, a $2^{\mathrm{a}}$ Escola Vocacional Parqueana da cidade. De acordo com o jornal Diário da Manhã do dia 10 de abril de 1966, "trata-se de mais um núcleo educacional pertencente à Municipalidade, pioneiro nessa modalidade de ensino, abrigando crianças que permanecerão aos cuidados de professoras especializadas". (DIÁRIO DA MANHÃ, 1966). Entretanto, o parque continuou funcionando, tanto que em 13 de maio de 1967, o jornal Diário da Manhã publicou que o parque estava em festa, por causa dos seus 4 anos de existência.

Momento de intensa animação e amizade viveram a diretora, os professores e alunos do Parque Infantil dos Bandeirantes, quando da comemoração de mais um aniversário daquela entidade educacional pertencente ao Departamento de Educação e Cultura da Prefeitura Municipal.

Do programa cuidadosamente elaborado pelo corpo docente da referida entidade municipal constaram números musicais, poesias, declamação, e farto almoço que foi servido aos presentes.

Parabéns ao Parque Infantil dos Bandeirantes que realmente vem cuidando da educação e recriação dos seus parqueanos e da unidade necessária entre família e a escola. (DIÁRIO DA MANHÃ, 1967).

\footnotetext{
${ }^{108}$ A fotografia pode ser encontrada no Arquivo Público e Histórico de Ribeirão Preto, no fundo Cel. Alfredo Condeixa Filho, na Pasta 88, ${ }^{\circ}$ de registro 1100.
} 
Cinco anos depois, na semana em que o Parque Infantil dos Bandeirantes comemorou 9 anos de inauguração, uma polêmica surgiu e foi noticiada pelo jornal Diário da Manhã, em 10 de maio de 1972:

\begin{abstract}
'Nenhum dos senhores deve comunicar nada disso aos jornais e rádios, principalmente ao repórter Antônio Carlos Morandini', foi o que afirmou uma das professoras (não se sabe se a diretora) do parque Infantil dos Bandeirantes, ao anunciar aos pais de alunos matriculados naquele parque que cada criança deveria 'contribuir' com mil cruzeiros mensais. Falou-se que todo o dinheiro arrecadado seria empregado na compra de brinquedos às crianças por ocasião das festas de fim de ano. Falou-se também que seria a verba arrecadada destinada à compra de uniformes aos alunos menos favorecidos. Segundo uma professora do Bandeirantes, a determinação partiu da sra. Ana Franco do Amaral, do Departamento de Educação da Prefeitura. A medida está provocando protestos de parte de pais de alunos matriculados naquele parque infantil, os quais estão ameaçando retirar seus filhos daquele estabelecimento caso persista a obrigatoriedade da 'contribuição'. Embora houvesse a recomendação de que ninguém deveria relatar nada à imprensa, principalmente ao 'repórter Morandini', a reportagem do Diário de Notícias tomou conhecimento do fato, faz questão de estampá-lo para que não o repórter, mas o prefeito tome as devidas providências. (DIÁRIO DE NOTÍCIAS, 1972, grifo nosso).
\end{abstract}

Não foram encontradas informações do que se sucedeu após essa publicação, mas notase que o parque já não era mais visto como a pérola da educação ribeirão-pretana, uma vez que os pais estavam ameaçando retirar seus filhos daquele estabelecimento.

Em 1 de outubro de 1980, por meio da Lei no 3839 (RIBEIRÃO PRETO, 1980a) assinada pelo prefeito Dr. Antônio Duarte Nogueira, o parque se tornou Escola Básica de $1^{\circ}$ Grau "Bandeirantes" e em 1985 se tornou Escola Municipal de Ensino Infantil dos Bandeirantes, na ocasião em que o prefeito João Gilberto Sampaio alterou a denominação das Escolas Básicas de $1^{\circ}$ Grau para Escolas Municipais de Educação Infantil, através da Lei $n^{\circ}$ 4696 (RIBEIRÃO PRETO, 1985).

Em 15 de junho de 1990, por meio da Lei no 5747 (RIBEIRÃO PRETO, 1990), o prefeito Dr. Welson Gasparini alterou o nome da escola de Bandeirantes para Professora Marlene Jorge Reis. De acordo com o histórico da instituição a professora Marlene Jorge dos Reis faleceu em 1989 e, como homenagem póstuma, foi dado seu nome à escola, pois além de ter sido militante durante muitos anos em escolas públicas da cidade e por último na Escola Municipal de Educação Infantil dos Bandeirantes, também "dedicou grande parte de sua vida 
ao amor ao próximo e amparo aos menores carentes". (PREFEITURA MUNICIPAL DE RIBEIRÃO PRETO) ${ }^{109}$.

\subsection{Os parques infantis de Ribeirão Preto pós-1963}

Não foram encontradas imagens dos parques infantis ribeirão-pretanos pós-1963, estes: Ana dos Santos Gabarra (1965); Padre Emílio Jarbinet (1967); Professora Áurea Apparecida Braghetto Machado (1970); Euclides Castilhano (1975); Parque Infantil José Pedro Moreira (1977); e Campos Elíseos (sem data). Apesar disso, algumas informações, apesar de poucas, foram encontradas:

\subsubsection{Parque Infantil Ana dos Santos Gabarra}

Localização: Rua Cel. Luiz Da Silva Batista, 61 - Jardim Irajá.

Em 27 de dezembro de 1962, por meio da Lei nº 1274 (RIBEIRÃO PRETO, 1962), o prefeito Cel. Alfredo Condeixa Filho criou um Parque Infantil no bairro de Santa Cruz do José Jacques ${ }^{110}$. Entretanto, o parque não foi construído nessa época.

De acordo com uma notícia publicada no jornal Diário da Manhã, em 31 de março de 1965, sobre obras municipais em andamento visitadas pelo prefeito Dr. Welson Gasparini, deixa claro que somente em 1965 o parque foi construído:

Também o Parque Infantil de Santa Cruz, cujas obras se encontraram bem adiantadas, foi visitado. $\mathrm{O}$ parque está situado entre dois bairros e servirá às crianças de ambos estando em andamento as mesmas obras constantes dos demais, como refeitório, recreio, campo, piscina, etc. (DIÁRIO DA MANHÃ, 1965).

Em 16 de julho do mesmo ano, o jornal Diário da Manhã publicou uma nota afirmando que o prefeito municipal Wilson Gasparini havia baixado um decreto no dia 15 de julho de 1965, denominando Ana dos Santos Gabarra o Parque Infantil de Santa Cruz. Informa ainda que o parque estava quase pronto e que provavelmente seria inaugurado no fim de julho. Contudo, não foi encontrado esse decreto.

\footnotetext{
${ }^{109}$ PREFEITURA MUNICIPAL DE RIBEIRÃO PRETO. EMEI Marlene Jorge dos Reis. Disponível em: https://www.ribeiraopreto.sp.gov.br/seducacao/escolas/marlene/i15marlene.php>. Acesso em: 21 maio 2015.

${ }^{110} \mathrm{Na}$ década de 1960 o bairro de Santa Cruz do José Jacques é o que atualmente conhecemos como subsetor S-3 (Jardim Irajá).
} 
No dia 24 de julho de 1965 o jornal Diário da Manhã informou à sociedade ribeirãopretana que, no dia seguinte, seria inaugurado o parque infantil com homenagem a Sra. Ana dos Santos Gabarra.

É sem dúvida uma obra de grande alcance social, há muito reclamada pela ordeira e operante população de Santa Cruz do José Jacques que, somente agora, através do dinamismo do prefeito Dr. Welson Gasparini, recebe com justa satisfação esse importante melhoramento.

Dotado de todos os requisitos técnicos indispensáveis, aliados a uma arquitetura arrojada e funcional irá o Parque Infantil de Santa Cruz do José Jacques, sem dúvida alguma, cumprir rigorosamente suas finalidades, quais sejam, instruir, educar e assistir grande parte de nossa infância, contribuindo dessa forma para uma sociedade futura mais autêntica e bem organizada. (DIÁRIO DA MANHÃ, 1965).

Atualmente, o parque é a Escola Municipal de Educação Infantil Ana dos Santos Gabarra. De acordo com o histórico da instituição ${ }^{111}$, o parque era conhecido também como Parque Infantil do Irajá e que "pouco tempo depois, ao terminar o Parque Infantil de Irajá, deuse o nome de Ana Santos Gabarra, que até hoje abriga esta imensidão de crianças, e Dona Ana, que sempre amou e viveu para as mesmas, continua a paraninfar a educação da Juventude". (PREFEITURA MUNICIPAL DE RIBEIRÃO PRETO). De acordo com o histórico, Ana dos Santos Gabarra era sempre animada, alegre e:

tinha verdadeira obsessão por ver seus filhos estudar e ter uma profissão liberal. Em todas as dificuldades apelava para o Sagrado Coração de Jesus e de Maria que havia intronizado em sua sala e as dificuldades desapareciam. Em 1955, quando os Diários Associados lançaram o Concurso da Mãe Paulista, foi eleita a Mãe do Ano. (PREFEITURA MUNICIPAL DE RIBEIRÃO PRETO).

\subsubsection{Parque Infantil Padre Emílio Jarbinet}

Localização: Rua João Ribeiro, 833 - Vila Lapa.

${ }^{111}$ PREFEITURA MUNICIPAL DE RIBEIRÃO PRETO. EMEI Ana dos Santos Gabarra. Disponível em: <https://www.ribeiraopreto.sp.gov.br/seducacao/escolas/gabarra/i15gabarra.php>. Acesso em: 20 maio 2015. 
Em 21 de fevereiro de 1963 o prefeito Cel. Alfredo Condeixa Filho ${ }^{112}$ autorizou, por meio da Lei $\mathrm{n}^{\circ} 1282$, a construção de um parque infantil no bairro da Lapa ${ }^{113}$ "em local que mais consulte os interesses do município e da população infantil”. (RIBEIRÃO PRETO, 1963c). Em 07 de dezembro de 1965, o Decreto nº 067, assinado pelo prefeito Dr. Welson Gasparini, desapropria área de terra destinada à construção de parque infantil no bairro da Lapa.

Uma área de forma irregular, situada nesta cidade, na confluência das ruas Coelho Neto e Vicente Golfeto, de propriedade do Sr. HERMINIO BARICHELLO ou de quem de direito, com a área de $2.973,60 \mathrm{~m} 2$, medindo pela rua com a Coelho Neto 55,40 m. lineares, $60 \mathrm{~m}$. lineares pela rua Vicente Golfeto e 47,35 m. lineares por um dos lados. (RIBEIRÃO PRETO, 1965a).

No dia 04 de março de 1966, o jornal Diário da Manhã publicou uma nota afirmando que em breve seriam realizadas as solenidades de lançamento da pedra fundamental das futuras instalações do Parque Infantil da Lapa.

Em 11 de maio de 1967 o jornal Diário da manhã informou que o Parque Infantil da Lapa seria inaugurado no dia 28 do mesmo mês e que já estava em funcionamento desde o início do ano letivo.

Sem dúvida alguma, um dos pontos da atual administração é a atenção especial dedicada à Educação e, desta feita, nossa cidade conta com mais um núcleo educacional.

A referida entidade, já em funcionamento regular, abrigando cerca de 350 crianças do próprio bairro, bem como aquelas que residem nas imediações, visa dar melhor educação, sistema moderno de recreação infantil e, ainda, assistência médico-odontológica. (DIÁRIO DA MANHÂ, 1967).

Em 26 de dezembro de 1968, o prefeito Dr. Welson Gasparini, por meio do Decreto n. 147 (RIBEIRÃO PRETO, 1968a), denomina "Padre Emílio Jarbinet" o parque infantil no bairro da Lapa, considerando que o Padre Emílio Jarbinet havia prestado "relevantes serviços, na qualidade de Vigário da Paróquia do Senhor Bom Jesus da Lapa, gozando de grande prestígio e admiração dos moradores do bairro da Lapa”. (RIBEIRÃO PRETO, 1968a).

Atualmente o parque é a Escola Municipal de Ensino Infantil Padre Emílio Jarbinet.

\footnotetext{
${ }^{112}$ Cel. Alfredo Condeixa Filho foi um dos prefeitos de Ribeirão Preto que mais leis, decretos e resoluções promulgou sobre os parques. Antes de alcançar a patente de Tenente-Coronel e ser prefeito de Ribeirão Preto, de acordo com Tânia Registro (2013), foi instrutor de educação física. Dessa maneira, como, a princípio, nos parques era oferecida a Educação Física para disciplinar e socializar as crianças somado à ideia de educação integral, é presumível que Cel. Alfredo Condeixa Filho valorizava os parques principalmente por esse motivo. ${ }^{113} \mathrm{Na}$ década de 1960, o bairro da Lapa é o que atualmente denominamos como o subsetor N-1.
} 


\title{
2.4.3 Parque Infantil Professora Áurea Apparecida Braghetto Machado
}

\author{
Localização: Rua Severiano Joaquim Bruno, 230 - Jd. Antártica.
}

Em 14 de maio de 1973 o prefeito Antônio Carlos Morandini ${ }^{114}$ promulgou a Lei ${ }^{\circ}$ 2756 (RIBEIRÃO PRETO, 1973a) que cria um parque infantil no bairro Vila Lobato ${ }^{115}$ e em 01 de dezembro de 1975, através do Decreto no 376 (RIBEIRÃO PRETO, 1975), o prefeito Dr. Welson Gasparini denomina tal parque infantil como "Professora Áurea Apparecida Braghetto Machado". Atualmente o parque é a Escola Municipal de Ensino Infantil Áurea Apparecida Braghetto Machado. De acordo com o histórico da instituição:

Em 23 de março de 1973, através do Ofício 116/73, assinado pelo então Prefeito de Ribeirão Preto, Dr. Welson Gasparini, foi enviado ao Exmo. Sr. Dr. Osório Carlos do Nascimento DD. Presidente da Câmara Municipal de Ribeirão Preto, encaminhamento para apreciação dos dignos Edis, o projeto de lei incluso, que dispõe sobre a criação do Parque Infantil localizado na Vila Lobato.

O Parque Infantil em apreço já vem funcionando há algum tempo, não tendo sido, ainda, criado por lei.

Entretanto, dada a necessidade da continuidade do seu funcionamento, em razão de atender plenamente às necessidades daquele bairro, no que tange a recreação às crianças em idade pré-escolar, solicitamos seja este projeto apreciado dentro do prazo estabelecido no artigo $26-\S 1^{\circ}$ da Lei Orgânica dos Municípios. (PREFEITURA MUNICIPAL DE RIBEIRÃO PRETO) $)^{116}$.

Percebe-se que o Parque Infantil de Vila Lobato já existia antes da sua lei de criação, tanto que o Decreto $\mathrm{n}^{\circ} 168$ de 12 de setembro de 1972 (RIBEIRÃO PRETO, 1972a), oito meses antes da lei de criação de tal parque, declara de utilidade pública área de terreno localizada na cidade, no bairro de Vila Tibério, destinada à ampliação do parque infantil de Vila Lobato.

O terreno de forma irregular, localizado nesta cidade, no Bairro de Vila Tibério, com frente para a rua João Alves Pereira, lado ímpar da numeração desta rua, com a seguinte dimensão e confrontação: frente para a rua João Alves Pereira, com 17,28 metros; do lado direito de quem desta rua olha para o imóvel, com 33,35 metros e confronta-se com terrenos de João Batista Said; do lado esquerdo com 34,50 metros e confronta-se com o Parque Infantil de Vila Lobato e nos fundos com

\footnotetext{
${ }^{114}$ Antônio Carlos Morandini foi Vice-Prefeito durante o mandato do prefeito Dr. Welson Gasparini, de 31 de janeiro de 1973 a 31 de janeiro de 1977, e assumiu o cargo de Prefeito Municipal interinamente entre 30 de abril e 28 de maio de 1973.

${ }^{115} \mathrm{Na}$ década de 1970 o bairro Vila Lobato é o que atualmente representa-se como o subsetor O-5 (Vila Monte Alegre, Jardim Antarctica, Jardim Santa Luzia e parte da Vila Manoel Junqueira).

116 PREFEITURA MUNICIPAL DE RIBEIRÃO PRETO. EMEI Áurea Apparecida Braghetto Machado. Disponível em: 〈https://www.ribeiraopreto.sp.gov.br/seducacao/escolas/aurea/i15aurea.php>. Acesso em: 20 maio 2015.
} 
25,60 metros, confrontando-se com os prédios de nºs. 288, 294 e 298 da rua Severino Joaquim Bruno, com a área total de 714,52 metros quadrados, de propriedade de JOÃO BATISTA SAID ou sucessores. (RIBEIRÃO PRETO, 1972a).

Há também um documento no Fundo Escolas Municipais da Secretaria Municipal de Planejamento apontando que a inauguração do parque aconteceu no dia 07 de abril de 1970.

\subsubsection{Parque Infantil Euclides Castilhano}

Localização: Rua Hermínio Félix Bonfim, s/n. - Guatapará ${ }^{117}$.

Poucas informações foram encontradas a respeito do Parque Infantil Euclides Castilhano. Todavia, sabe-se que, em 27 de julho de 1974, o prefeito Dr. Welson Gasparini assinou Decreto n 098 (RIBEIRÃO PRETO, 1974) que abriu crédito especial de Cr\$ 200.000,00 para construção de um parque infantil no distrito de Guatapará, pois houve excesso de arrecadação previsto para o corrente exercício e assim a cidade teria recursos para a construção do parque.

Uma pista que aponta a existência do parque é o Dossiê sobre a sua construção, depositado no Arquivo Municipal de Ribeirão Preto. Nesse dossiê constam envelopes; cópias de um parecer da comissão que escolheria uma entre as empresas concorrentes que se dispunha a oferecer toda a mão de obra necessária para a construção do parque; memorial descritivo para a construção do parque; edital de concorrência; propostas de outras firmas; recortes das publicações no Diário Oficial; contrato entre a Prefeitura Municipal de Ribeirão Preto e a firma Victor de Araújo; recibos de pagamento, entre outros.

Em 20 de abril de 1975 o jornal Diário da Manhã publicou que já se encontrava em fase final de acabamento o Parque Infantil de Guatapará e que o terreno em que o prédio estava sendo construído tinha 2500 metros quadrados. De acordo com o jornal, a construção era moderna e funcional, e quando pronta teria condições de oferecer assistência a todas as crianças guataparenses.

De acordo com o memorial descritivo para a construção desse parque ${ }^{118}$, elaborado pela da Secretaria de Obras e Serviços da prefeitura (processo n ${ }^{\circ} 538$, documentos $n^{\circ} 28$ à 36):

\footnotetext{
${ }^{117}$ Atualmente, no local, fica o pronto-socorro da cidade.

${ }^{118} \mathrm{O}$ documento pode ser encontrado no Arquivo Público e Histórico de Ribeirão Preto, no fundo Educação, na Pasta $37, n^{\circ}$ de registro 871.
} 
Trata-se de um prédio térreo constando de: galpão, sanitário para meninos, sanitário para meninas, uma sala de aula, uma sala para uso do ambulatório, assistência médica e dentária, reuniões, etc., uma sala de diretoria, um sanitário masculino para adultos, um sanitário feminino para adultos, esses dois sanitários inclusive servindo como vestiário, bem como ainda despensa, uma cozinha, uma lavanderia e um coberto para lenheiro. $\mathrm{O}$ prédio inteiro apresenta como característica uma circulação externa com cobertura balanceada.

Foi encontrado também um documento no Fundo Escolas Municipais da Secretaria Municipal de Planejamento, o qual indica que o parque foi inaugurado em 21 de outubro de 1975.

Em 10 de outubro de 1980, o prefeito Dr. Antônio Duarte Nogueira, por meio da Lei $n^{\circ}$ 3839 (RIBEIRÃO PRETO, 1980a), alterou a denominação dos parques infantis para Escolas Básicas de $1^{\circ}$ Grau e um dos parques que teve de alterar o nome foi o de Guatapará, passando a se chamar Escola Básica de $1^{\circ}$ Grau "Euclides Castilhano".

A Escola Básica de $1^{\circ}$ Grau "Euclides Castilhano" virou a atual Escola Municipal de Educação Infantil e Ensino Fundamental Euclides Castilhano em 1985, quando o prefeito João Gilberto Sampaio assinou a Lei no 4696 (RIBEIRÃO PRETO, 1985). Cinco anos depois, Guatapará deixou de ser distrito de Ribeirão Preto em 09 de janeiro de 1990, por meio da Lei Estadual no 6645 (SÃO PAULO, 1990), deixando de responder às leis de Ribeirão Preto. Assim, em 1995, a sede, que ficava na Rua Hermínio Félix Bonfim, foi transferida para a Rua Aparecido Nunes, 310 - Nova Guatapará, onde mantém-se ainda hoje.

\subsubsection{Parque Infantil José Pedro Moreira}

Localização: Rua Major Ricardo Guimarães, 620 - Parque Ribeirão Preto.

Em 12 de julho de 1977, por meio da Lei no 3334 (RIBEIRÃO PRETO, 1977a), o prefeito Dr. Antônio Duarte Nogueira ${ }^{119}$ criou o parque infantil no bairro Vila Fraternidade ${ }^{120}$ e já o nomeou Parque Infantil Professor José Pedro Moreira. Entretanto, assim como outros

\footnotetext{
${ }^{119}$ O Dr. Antônio Duarte Nogueira foi um dos prefeitos de Ribeirão Preto que mais assinou leis, decretos e resoluções sobre os parques. Tal fato provavelmente possa estar relacionado a sua profissão de origem: médico, formado em 1963 pela Faculdade de Medicina da cidade e especialista em clínica médica. Afora isso, de 1964 a 1968 ocupou o cargo de Diretor do Departamento de Saúde da Prefeitura Municipal durante o mandato do prefeito Dr. Welson Gasparini, que já vinha promulgando várias leis sobre os parques. Ao então assumir a prefeitura em 1969, continuou a disseminar e implantar os parques na cidade, uma vez que estes têm forte assistência médico-higienista.

${ }^{120} \mathrm{Na}$ década de 1970 o bairro Vila Fraternidade é o que atualmente denomina-se subsetor O-8.
} 
parques, este também foi inaugurado antes da sua lei de criação, uma vez que, sete meses antes, em 05 de janeiro de 1977, o jornal A Cidade publicou:

O Parque Infantil de Vila Fraternidade, uma realização da atual administração municipal, encontra-se pronto e em condições de ser utilizado pela Secretaria da Educação, Cultura, Saúde e Bem-Estar do município a partir do próximo mês de fevereiro, atendendo a população de uma vasta região da cidade. (A CIDADE, 1977).

Atualmente o parque é Escola Municipal de Educação Infantil Professor José Pedro Moreira.

\subsubsection{Parque Infantil Campos Elíseos}

\section{Localização: Rua Tamandaré, 353 - Campos Elíseos.}

Não há muitas informações a respeito do Parque Infantil Campos Elíseos. Entretanto, de acordo com o histórico da Escola Municipal de Ensino Infantil Professora Carmem Massarotto $^{121}$, antes de ser inaugurada em 13 de novembro de 1984, ela funcionava como parque infantil e seu funcionamento acontecia no prédio da Escola Municipal de Ensino Fundamental e Médio Dom Luiz do Amaral Mousinho.

Dessa maneira, pode-se dizer que existiu um parque infantil nesse bairro, porém com características diferentes dos parques infantis de Ribeirão Preto das décadas de 50 e 60, que tinham prédios próprios, com rotinas e instalações semelhantes.

Sabe-se também que, em 27 de dezembro de 1966, por meio da Lei nº 1869 (RIBEIRÃO PRETO, 1966b), o prefeito Dr. Welson Gasparini ${ }^{122}$ criou a Escola Primária Vocacional

\footnotetext{
${ }^{121}$ PREFEITURA MUNICIPAL DE RIBEIRÃO PRETO. EMEI Professora Carmem Massarotto. Disponível em: <https://www.ribeiraopreto.sp.gov.br/seducacao/escolas/masaroto/i15masaroto.php>. Acesso em: 20 maio 2015.

${ }^{122} \mathrm{O}$ Dr. Welson Gasparini foi o prefeito de Ribeirão Preto que mais leis, decretos e resoluções assinou sobre os parques da cidade. Além de político, é radialista, jornalista, professor e advogado. De acordo com o website da Assembleia Legislativa do Estado de São Paulo (ALESP), o primeiro emprego do Dr. Welson Gasparini foi como repórter do jornal Diário de Notícias e depois locutor da rádio ZYR-79. Segundo Tânia Registro (2013), foi também presidente do Centro do Professorado Católico de Ribeirão Preto e Presidente do Sindicato dos Jornalistas Profissionais de Ribeirão Preto. Apesar de bem sucedido na carreira política, não deixou de trabalhar como professor, advogado e jornalista e atualmente é Deputado Estadual atuando no desenvolvimento regional e uma de suas metas é a concretização da instalação da Faculdade de Tecnologia (FATEC) em Ribeirão Preto. Dessa maneira, vê-se que ainda hoje o Dr. Welson Gasparini luta a favor da educação. Inclusive, em 04 de julho de 2014, publicou no website BrasilAgro que a forma mais rápida para vencer o triste quadro de injustiças, violências e incompetências que causam sérios prejuízos ao nosso desenvolvimento econômico e social é o investimento na melhoria da educação nas escolas públicas. De acordo com o próprio Dr. Welson Gasparini (Informação recebida via e-mail, em 06 jun. 2015. O contato com foi mediado pela sua filha, Luciana Gasparini.), seu investimento nos parques infantis foi pela importância da educação e por acreditar desde aquela
} 
Municipal denominada Professora Carmem Cecília Massaroto, que foi inaugurada em 21 de maio de 1967, de acordo com jornal Diário da Manhã de 20 de maio de 1967.

Dentro do plano de expansão do ensino e educação em nosso município, este é um empreendimento pioneiro do prefeito municipal Dr. Welson Gasparini, dentro da sua dinâmica administrativa, pois a criança, o adolescente e o adulto vem merecendo especial atenção.

Sabe-se que a prefeitura municipal, quanto aos problemas educacionais, tem dedicado não só maior porcentagem de suas verbas como, também, um carinho todo especial.

ESCOLA VOCACIONAL MUNICIPAL

Assim era chamada a atual Escola Vocacional desde fevereiro de 1964, funcionando regularmente nos anos de 1965, 1966 e 1967, contou com a colaboração de professoras dedicadas, colocando-se em relevo, o trabalho de Carmem Cecília Massaroto que de maneira brilhante soube acarinhar as suas crianças. Hoje à Escola Primária Vocacional Carmem Cecília Massaroto é uma homenagem póstuma àquela que não mediu esforços e sacrifícios na concretização de um ideal, e tendo como diretora a sra. Theodolinda V. Pardi e um grupo de professoras especializadas é levado adiante tudo aquilo que constituiu a razão de ser de Carmem Massaroto e o Dr. Alfeu Gasparini.

EDUCACÃO INTEGRAL DA CRIANÇA

Assim, o Primário Vocacional com novo sistema de ensino, tem classes regulamentares, formadas de 20 alunos, entre meninos e meninas, que, divididos em equipes desenvolvem seus trabalhos e estudos.

As crianças permanecem na escola 8 horas convivendo e aprendendo com os mestres as matérias fundamentais, preparando-se para a escola secundária, e na parte da tarde o tempo é dedicado à cultura geral, proporcionando condições para o desenvolvimento e exercício de suas profissões para as quais tem inclinação. (DIÁRIO DA MANHÃ, 1967, grifo nosso).

Em 23 de agosto de 1973, através da Lei no 2778 (RIBEIRÃO PRETO, 1973b), a Escola Primária Vocacional Municipal Professora Carmem Cecília Massaroto transformou-se em Unidade Municipal de Ensino de $1^{\circ}$ Grau e em 1985 transformou-se na atual Escola Municipal de Ensino Infantil Professora Carmem Massarotto, quando o prefeito João Gilberto Sampaio assinou a Lei no 4696 (RIBEIRÃO PRETO, 1985).

Há um documento no Fundo Escolas Municipais da Secretaria Municipal de Planejamento indicando que essa escola foi inaugurada, como possível parque infantil, em 01 de fevereiro de 1981. Entretanto, é um dado que não se enquadra com as informações encontradas a respeito dessa instituição, pois antes de ser transformada em Escola Primária Vocacional Municipal em 1966, já era uma Escola Vocacional Municipal desde 1964 e todas as Escolas Vocacionais da cidade, daquele período, eram instaladas somente em parques

época que a educação começa na infância. Dessa maneira, pode-se afirmar que a luta pela educação desde a infância foi o motivo para o Dr. Welson Gasparini ter, desde a década de 60, assinado tantas leis a favor dos parques infantis da cidade. 
infantis, ou seja, a atual Escola Municipal de Ensino Infantil Professora Carmem Massarotto foi um possível parque infantil, não legalizado, antes de 1964.

O interessante desse parque é que, após virar Escola Primária Vocacional Municipal, teve como patrona a Professora Carmem Cecília Massarotto, uma das primeiras professoras do Parque Infantil dos Bandeirantes. 


\section{SISTEMATIZANDO FONTES E DADOS PARA UMA DISCUSSÃO SOBRE A CONSTRUÇÃO DE IMAGENS PÚBLICAS}

Nesse capítulo, a partir de todas as fontes oficiais coletadas e de como tentamos reconstruir todo o panorama dos parques infantis no capítulo anterior, sistematizaremos alguns dados para abrir caminhos para pensar a imagem pública construída pelas administrações municipais de Ribeirão Preto das décadas de 1950 e 1960. Esta imagem é extremamente parcial, pois não há vozes discordantes, uma vez que todas as vozes são oficiais e positivas. Mas se tudo era tão bom, porque que os extinguiram da cidade?

Fora isso, além de extintos houve ainda uma obliteração em relação à memória dos parques infantis, sendo que no início dos anos 1980 eles foram transformados em Escolas Básicas de $1^{\circ}$ Grau pela Lei no 3839 (RIBEIRÃO PRETO, 1980a) de 10 de outubro de 1980, e desde então os anos continuados de sua existência e atividade parecem ter caído no esquecimento.

Para compreender essa construção de imagem pública, primeiro é necessário que haja uma reflexão e problematização em torno das fontes históricas. Para Maria Stephanou e Maria Helena Camara Bastos (2011, p. 419), o movimento teórico e metodológico da história em refletir que os documentos não expressam significados coerentes, não são transparentes e foram produzidos segundo determinados interesses e estratégias, deve ser destacado e os historiadores hoje devem perguntar como ele funciona, e não o que significa. Carlos Bacellar (2014, p. 63) afirma que "documento algum é neutro, e sempre carrega consigo a opinião da pessoa e/ou do órgão que a escreveu". O autor aponta também que "um dos pontos cruciais do uso de fontes reside na necessidade imperiosa de se entender o texto no contexto de sua época, e isso diz respeito, também ao significado das palavras e expressões”. (BACELLAR, 2014, p. 63).

Nesse sentido, os vários artigos de jornais que lemos por ocasião da pesquisa e que tratavam dos parques infantis, no caso dos transportes utilizados para levar e buscar as crianças de suas casas nos bairros populares (alguns deles com áreas de favela) aos parques infantis, indicam que o discurso jornalístico reiterava o caráter de assistência, socorro, amparo e doação do poder público aos pobres, especialmente aos seus filhos e filhas, a fim de demonstrar às outras classes sociais (plenas de cidadãos e eleitores) a política posta em prática para amparar e educar os desassistidos.

Se os textos jornalísticos tiveram influência indireta da administração municipal na sua elaboração, a documentação iconográfica encontrada no Arquivo Público e Municipal de 
Ribeirão Preto e a legislação municipal são de autoria do poder público e dos seus agentes e administradores durante as décadas de 1950 e 1960 e que hoje servem de base para a construção do conhecimento histórico a respeito dos parques infantis de Ribeirão Preto dessa época.

Entre as fontes de autoria oficial, as leis municipais nos chamaram a atenção, a princípio, devido à diferença nas datas das leis de criação e da inauguração de cada parque, como podese notar no quadro $3^{123}$. Em vista disso, foi realizado um levantamento com todas as leis, decretos e resoluções municipais referentes aos parques infantis, sendo a primeira lei de 1949 e a última de 1980.

Quadro 3 - Diferenças entre as datas de inauguração e leis de criação dos parques infantis de Ribeirão Preto

\begin{tabular}{|l|c|c|c|}
\hline \multicolumn{1}{|c|}{ Nome } & Inauguração & $\begin{array}{c}\text { Lei de } \\
\text { criação - } \\
\text { data }\end{array}$ & $\begin{array}{c}\text { Lei de } \\
\text { criação } \\
\text { número }\end{array}$ \\
\hline Parque Infantil Peixe Abbade & $08 / 12 / 1951$ & $20 / 04 / 1953$ & 292 \\
\hline Parque Infantil Amélia Junqueira & $12 / 05 / 1953$ & $11 / 11 / 1953$ & 333 \\
\hline Parque Infantil Anita Procópio Junqueira & $08 / 12 / 1954$ & $26 / 02 / 1957$ & 547 \\
\hline Parque Infantil Dona Iria Junqueira & 1954 & $11 / 07 / 1955$ & 425 \\
\hline Parque Infantil de Dumont & 1956 & $\mathrm{X}$ & $\mathrm{x}$ \\
\hline Parque Infantil de Guatapará & 1956 & $\mathrm{X}$ & $\mathrm{X}$ \\
\hline Parque Infantil Santa Maria Goretti & $05 / 01 / 1959$ & $11 / 08 / 1958$ & 345 \\
\hline Parque Infantil dos Bandeirantes & $12 / 05 / 1963$ & $08 / 04 / 1963$ & 1291 \\
\hline Parque Infantil Ana dos Santos Gabarra & $03 / 08 / 1965$ & $27 / 12 / 1962$ & 1274 \\
\hline Parque Infantil Padre Emilio Jarbinet & $28 / 05 / 1967$ & $21 / 02 / 1963$ & 1282 \\
\hline Parque Infantil Prof. Áurea A. Braghetto Machado & $07 / 04 / 1970$ & $14 / 05 / 1973$ & 2756 \\
\hline Parque Infantil Euclides Castilhano & $21 / 10 / 1975$ & $27 / 07 / 1974$ & 2903 \\
\hline Parque Infantil José Pedro Moreira & $05 / 01 / 1977$ & $12 / 07 / 1977$ & 3334 \\
\hline Parque Infantil dos Campos Elíseos & $\mathrm{x}$ & $\mathrm{x}$ & $\mathrm{x}$ \\
\hline
\end{tabular}

Fonte: produção do próprio autor

A primeira lei municipal que cita os parques infantis é a Lei no 97 (RIBEIRÃO PRETO, 1949), de 01 de julho de 1949, que dispõe sobre estruturação, classificação e a consolidação dos cargos e funções gratificadas dos servidores públicos municipais, entre outras providências.

Art. $1^{\circ}$ - Os serviços municipais ficam constituídos dos órgãos abaixo indicados, autônomos entre si, e diretamente subordinados ao Prefeito, a saber:

[...] X - Departamento de Cultura;

${ }^{123}$ As datas de inauguração dos parques inseridos no quadro 3 foram constatadas em diversos documentos do Arquivo Público e Histórico de Ribeirão Preto. 
a) Ensino;

b) Parque Infantis e Recreação;

c) Difusão Cultural e Museu;

d) Turismo. (RIBEIRÃO PRETO, 1949).

O Parque Infantil Peixe Abbade foi o primeiro parque infantil da cidade, inaugurado em 08 de dezembro de 1951. Entretanto, legalmente foi criado somente em 20 de abril de 1953, pela Lei no 292 (RIBEIRÃO PRETO, 1953a). Percebe-se que o mesmo ocorreu com os parques Amélia Junqueira, Anita Procópio Junqueira, Dona Iria Junqueira, Professora Áurea Apparecida Braghetto Machado e José Pedro Moreira. Não é possível afirmar o porquê de a tramitação legal ocorrer somente após a inauguração desses parques, mas há indícios de que era um costume de alguns políticos da época resolver a situação de determinado local e, apenas ao obter respostas positivas, oficializar os seus atos. Dessa forma, era possível acontecer de o mandato de alguns chegar ao fim e o seu sucessor é quem oficializava.

Pode-se notar no gráfico 1 que, em 31 anos, com exceção de 1950, 1952, 1956, 1967, 1970 e 1978, 65 leis, decretos e resoluções municipais foram elaborados, mostrando que realmente havia uma preocupação por parte das administrações municipais com os parques infantis da cidade. Percebe-se, pelo gráfico 2, que somente os parques de Guatapará, Dumont e dos Campos Elíseos não têm leis referentes a eles. Todavia, foram contemplados pelas 24 leis, decretos e resoluções municipais que foram elaboradas pensando em todos os parques da cidade, como por exemplo a Lei no 1787 (RIBEIRÃO PRETO, 1966a), de 31 de maio de 1966, a qual dispõe sobre a vacinação antitetânica dos alunos matriculados nos parques infantis municipais e a Lei no 2658 (RIBEIRÃO PRETO, 1972b), de 18 de julho de 1972, que autoriza o fornecimento diário de meio litro de leite pasteurizado a toda criança de até doze anos, cujos pais recebem, no máximo, um salário-mínimo regional, através de postos instalados nos parques infantis do município. 
Gráfico 1 - Número de leis, decretos e resoluções por ano sobre os parques infantis de Ribeirão Preto

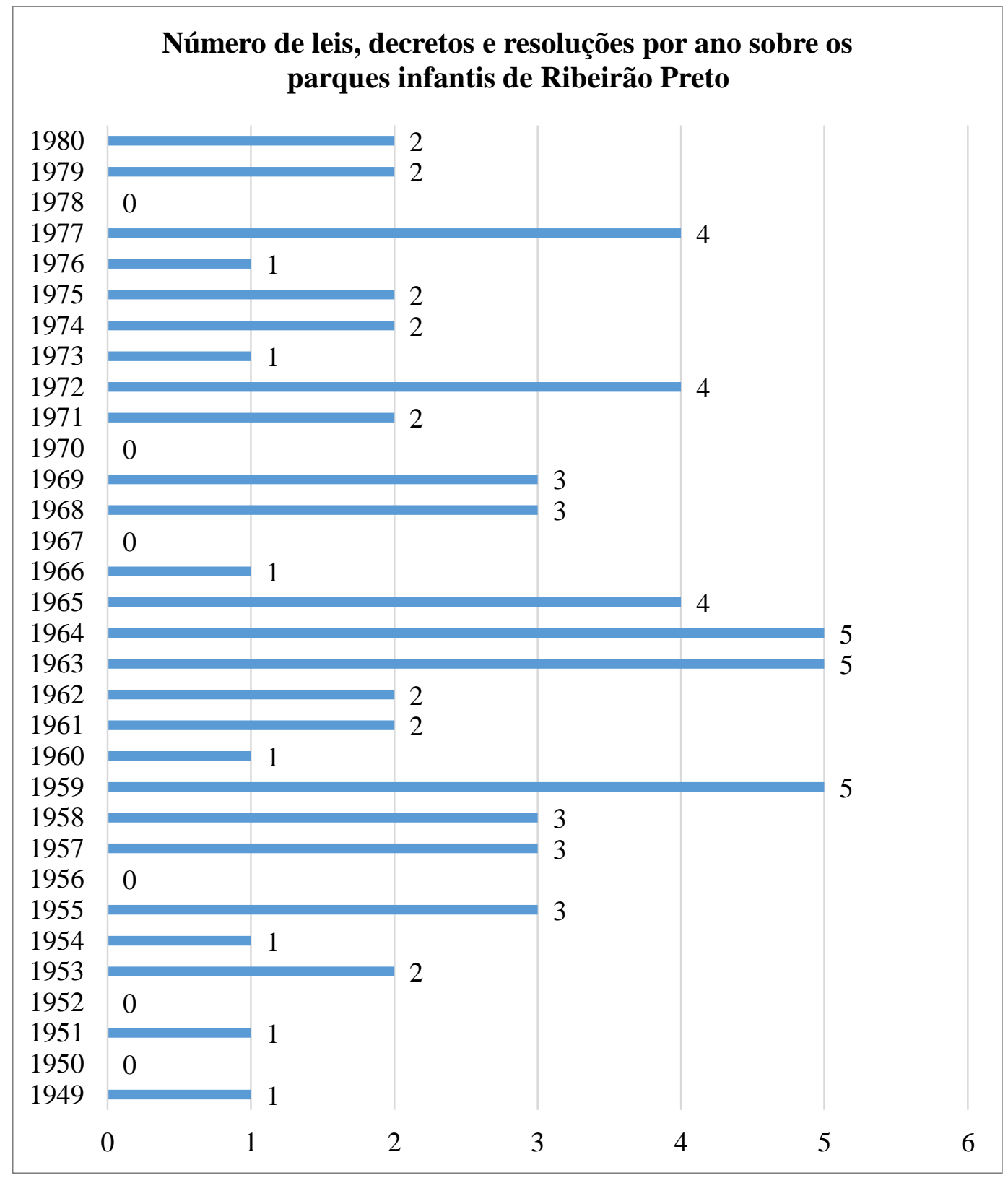

Fonte: produção do próprio autor 
Gráfico 2 - Leis, decretos e resoluções municipais sobre parques infantis da cidade

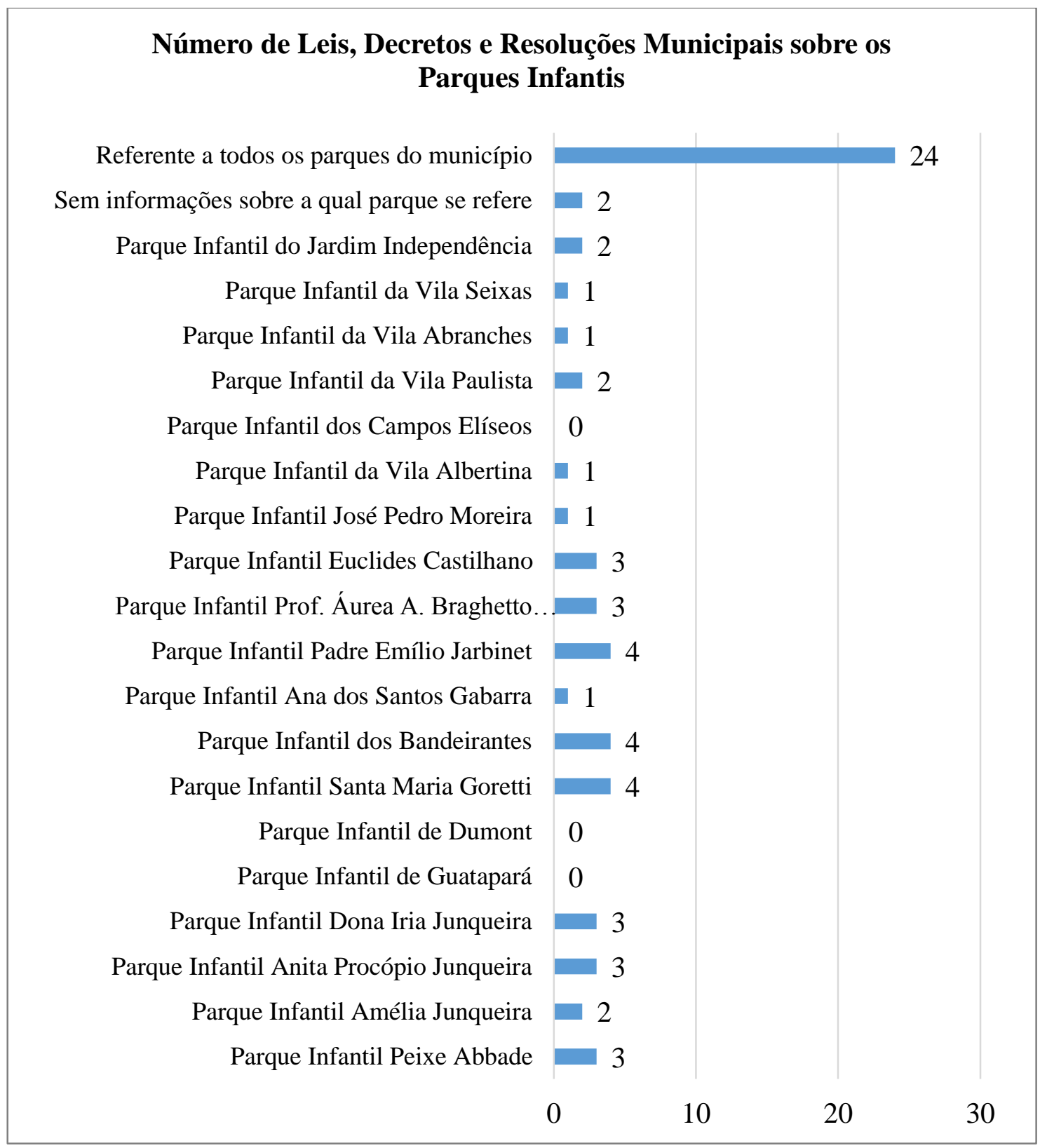

Fonte: produção do próprio autor

Algo interessante de se observar é que existem seis leis referentes a cinco parques infantis na cidade, mas estes nunca foram realmente instalados. A primeira é a Lei $n^{\circ} 890$ (RIBEIRÃO PRETO, 1959c), assinada pelo prefeito Áureo Norberto da Silva em 03 de dezembro de 1959, que criou o Parque Infantil de Vila Paulista (subsetor L-2) e a segunda, referindo-se ao mesmo parque, a Lei no 1276 (RIBEIRÃO PRETO, 1962b), que foi assinada em 27 de dezembro de 1962 pelo prefeito Cel. Alfredo Condeixa Filho, autorizando despender até cr\$5.000.000,00 para a construção deste parque. 
A terceira é a Lei no 1475 (RIBEIRÃO PRETO, 1964c), de 10 de novembro de 1964, assinada pelo prefeito Dr. Welson Gasparini, que autorizou a construção de um Parque Infantil na Vila Abranches (subsetor L-10). A quarta é a Lei no 1507 (RIBEIRÃO PRETO, 1964d), de 01 de dezembro de 1964, assinada pelo mesmo prefeito, criando um Parque Infantil na Vila Seixas (subsetor L-1).

A quinta é a Lei no 3395 (RIBEIRÃO PRETO, 1977b), de 19 de dezembro de 1977, assinada pelo prefeito Dr. Antônio Duarte Nogueira, que criou um Parque Infantil no Jardim Independência (subsetor N-5). A sexta é a Lei no 3618 (RIBEIRÃO PRETO, 1979), de 17 de maio de 1979, assinada pelo mesmo prefeito, que dispõe sobre a criação de um parque infantil na Vila Albertina (subsetor N-2). De acordo com a lei, esse parque deveria obedecer à estrutura e funcionamento do Parque Infantil Vila Virgínia e deveria se localizar na esquina das Ruas Espírito Santo com Rio Maroni.

Assim como os outros parques implantados na cidade, estes também seriam relativamente próximos, com exceção do parque que seria instalado na Vila Abranches (subsetor L-10), e nenhum seria instalado no centro (CE) da cidade, e sim em bairros periféricos e com população menos abastada - assim como os outros -, inclusive o parque que seria instalado na Vila Albertina, pois este ficaria localizado no mesmo subsetor do Parque Infantil dos Bandeirantes (subsetor N-2).

Analisando a legislação, é possível notar quais administrações municipais se preocuparam mais com os parques da cidade. De acordo com o gráfico 3, o Cel. Alfredo Condeixa Filho, o Dr. Welson Gasparini e o Dr. Antônio Duarte Nogueira foram os prefeitos que mais assinaram leis e decretos a respeito dos parques infantis da cidade, sendo Dr. Welson Gasparini com 17, Dr. Antônio Duarte Nogueira com 16 e Cel. Alfredo Condeixa Filho com 13. 
Gráfico 3 - Administradores municipais x número de leis, decretos e resoluções municipais

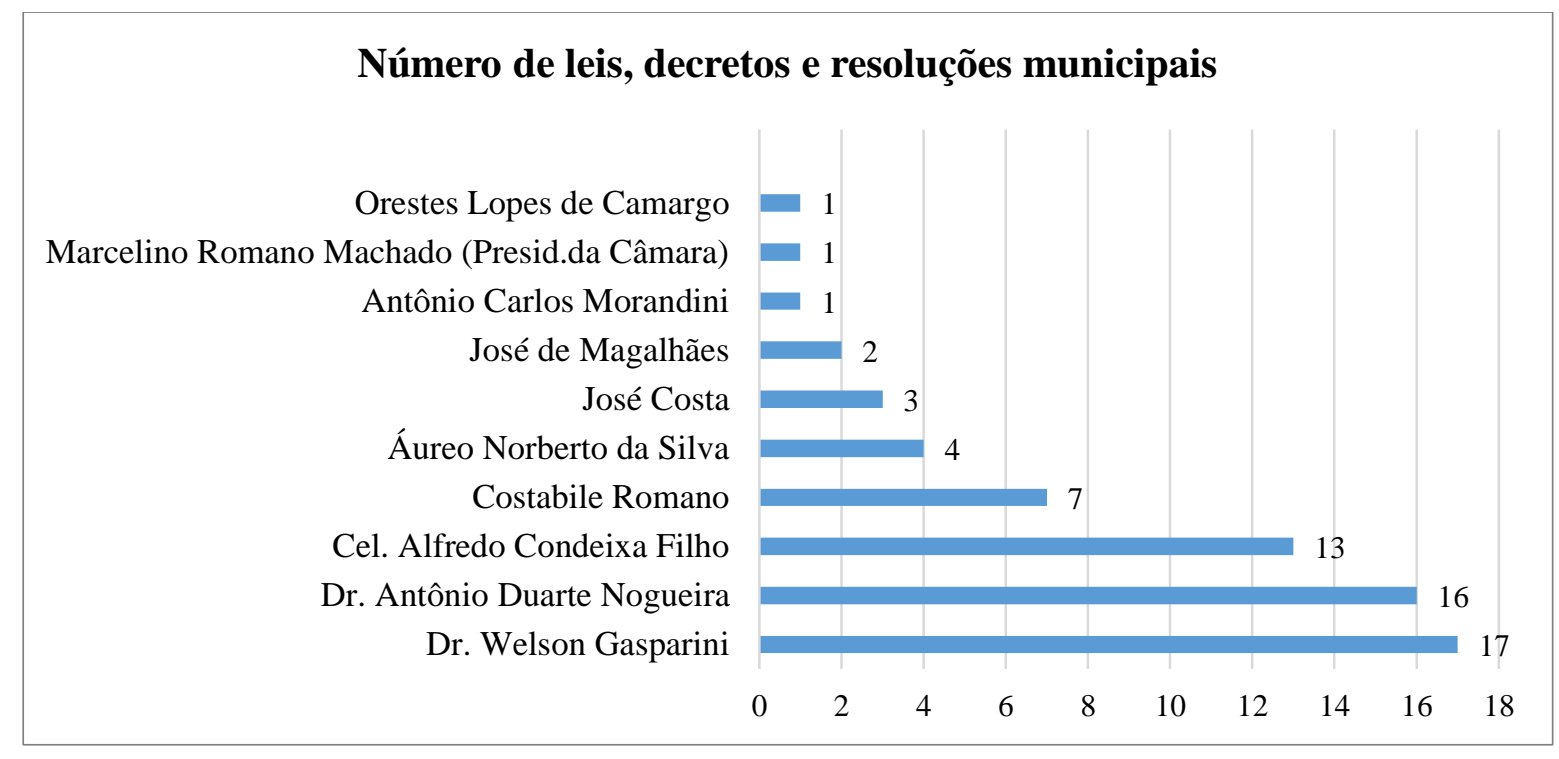

Fonte: produção do próprio autor

Realizar o levantamento da legislação municipal referente aos parques infantis possibilitou não somente situar cada parque na cronologia da cidade, a partir do conhecimento da criação de cada um, mas também explicitar o reconhecimento do papel que tinham como uma instituição da grande importância para a cidade e quais administradores municipais os valorizavam mais.

Em Ribeirão, assim como no decorrer da História, os jornais se tornaram veículos informativos privilegiados e, com isso, também "educadores” diários. De acordo com Raquel Discini de Campos (2012, p. 48, grifo do autor), "historiadores sociais da imprensa demonstraram o quanto tais veículos foram (e ainda são) inegavelmente também sujeitos da história, que se incumbem de registrar, explicar, discutir e comentar as coisas do mundo (CRUZ, 2000; DARNTON; LUCA, 2006; ROCHE, 1996)".

Vale salientar, ainda, como a importância da imprensa tem sido exaltada, conforme observa-se em texto de 1927:

Na vida intellectual como no progresso material dos povos, a imprensa aparece como uma das mais poderosas alavancas para levantal-los ao nível da verdadeira civilisação. Na instrucção scientifica e literária como na educação moral e econômica das nações, a imprensa é ainda um dos mais valiosos factores que agem na organisação dos elementos básicos dessas instituições. [...] A imprensa é um poder sobrehumano que vence todos os obstáculos, destroe os mais sólidos edifícios e levanta os ânimos abatidos transformandoos em energias robustas e benéficas. Ah! A imprensa! Como sua importância está longe de ser comprehendida! (LEMOS, 1927 apud CAMPOS, R., 2012, p. 50). 
A relação da imprensa com os parques infantis de Ribeirão Preto das décadas de 50 e 60 não foi diferente das relações que Lemos expõe na década de 20. Entretanto, os jornais da cidade não vigoravam apenas como uma poderosa alavanca para levantar a cidade ao nível de civilização, pois eles expunham indiretamente suas aspirações e interesses. Percebe-se isso ao notar que Costabile Romano ${ }^{124}$, prefeito de Ribeirão Preto de 1955 a 1959, foi jornalista, proprietário e diretor do jornal Diário da Manhã e também foi fundador do jornal O Diário em 1956.

Em 4 de outubro de 1947, no jornal Diário da Manhã, junto à notícia "Batalhando pela infância escolar", havia uma pequena nota com os seguintes dizeres: "se és trabalhador, és do povo - teu candidato é Costabile Romano, um trabalhador que governará Ribeirão Preto para o bem dos trabalhadores". No dia seguinte, preenchendo por completo a primeira página do jornal, encontrava-se uma propaganda eleitoral com os dizeres "TRABALHADOR: para prefeito o teu voto pertence a COSTABILE ROMANO - o candidato que saiu do povo". Sabese que Costabile não venceu essa eleição, mas continuou na direção do jornal e também publicando artigos sobre infância e, com a chegada dos parques infantis na cidade, também sobre eles. Alguns artigos publicados tinham os seguintes títulos: Delinquência Infantil; A serviço da infância ribeirão-pretana; Missão social da professora; Infância abandonada e delinquente; entre outras.

Desse modo, observando a relação entre imprensa e poder, cabe aqui retomar a seguinte reflexão de Raquel Campos (2012, p. 59):

March Bloch, Michel de Certeau, Jacques Le Goff e outros mestres da nossa oficina contemporânea demonstraram que é preciso estar atentos às intenções de quem produziu os jornais, à sua função num dado grupo social, aos pontos de vista explícitos e implícitos nos argumentos dos que escrevem, fotografam, desenham, pintam, diagramam e finalmente leem não apenas esses artefatos culturais, mas qualquer tipo de fonte.

Por isso, ao manusear um jornal, necessitamos, antes de tudo, pensar, juntamente com os nossos mestres de ofício, em texto, contexto e técnicas de produção; ou em discurso, na acepção de um texto observado na situação de comunicação que o sustenta, o que supõe um posicionamento social e historicamente marcado do sujeito que produziu o jornal.

\footnotetext{
${ }^{124}$ Segundo Tânia Registro (2013, p. 20), “Costabile Romano nasceu em São Paulo, SP, em 30/07/1905. Filho dos italianos Antônio Domingos Romano (natural de Castelabate - Província de Palermo) e Thomazina Russo (natural de Nápoles). Era irmão de José Romano, Edmundo Paulo Romano e Ângelo Romano. Em 1922 mudouse para Ribeirão Preto onde trabalhou na padaria de seu pai instalada na Praça Coração de Maria, no bairro Vila Tibério. No ano de 1927 iniciou suas atividades profissionais como jornalista no jornal Diário da Manhã; posteriormente, entre os anos de 1933 a 1950, foi proprietário daquele jornal. Em 1956 fundou o jornal O Diário. Foi um dos fundadores da Associação Paulista de Imprensa, ocupando o cargo de conselheiro e diretor durante 15 anos. Foi Presidente da Liga Ribeirão-pretana de Futebol e Presidente do Botafogo Futebol Clube de Ribeirão Preto de 1949 a 1951. Foi eleito Prefeito de Ribeirão Preto no período de 1956 a 1959; durante os anos em que esteve a frente da Prefeitura Municipal foram executadas várias obras".
} 
Nota-se que, os jornais pesquisados, apesar de terem uma posição política assumida, são peças de extrema importância no desvendar de fragmentos possíveis a respeito dos parques infantis de Ribeirão Preto, pois são eles que nos permitem reunir elementos que podem identificar detalhes do cotidiano dos parques e também informações que o poder público procurava disseminar por meio deste veículo privilegiado de informação.

A procura nessa pesquisa, então, não foi encontrar uma verdade única e certeira sobre o passado desses parques, e sim pistas admissíveis sobre eles. Afinal, como afirma Raquel Campos (2012, p. 65), "pela leitura de jornais antigos conseguimos nos aproximar de projeções coletivas sobre um tempo de então, sobre atores e espaços dados em relação de anterioridade uma anterioridade presentificada no ato e pelo ato da pesquisa".

Outra parte considerável da documentação sobre os parques infantis de Ribeirão Preto é iconográfica. Desse modo, emergem-se novas questões concernentes à importância da imagem como documento de valor histórico, pois:

A fotografia produz um efeito mágico quando transpõe a realidade para a forma de imagem. Paradoxalmente, ela leva-nos para uma temporalidade distante, mas ao mesmo tempo permite grande efeito comunicativo na temporalidade presente, além de nos apontar a estética como dimensão importante de nossa subjetividade. (VASCONCELLOS, 1995, p 16).

O Ato Municipal no 767, de 9 de janeiro de 1935, de São Paulo (SÃO PAULO, 1935), que criou o Serviço Municipal de Jogos e de Recreio para crianças, em seu artigo $5^{\circ}$, traz que o Chefe do Serviço deveria, além de todos seus deveres, divulgar os trabalhos e os resultados obtidos pelos parques, como, também, através de publicações, abrir espaço para estudo e debate dos problemas relativos aos parques. Do mesmo modo que São Paulo da década de 1930, as administrações municipais de Ribeirão Preto, principalmente das décadas de 1950 e 1960, promoviam e informavam ao público o trabalho educativo e assistencial desenvolvido nos seus parques através de publicações com relatos e imagens fotográficas.

As séries de fotografias sobre os parques infantis de Ribeirão Preto fazem parte de comemorações dos feitos das administrações municipais durante a década de 1950 e também integram séries de imagens avulsas guardadas no acervo do Arquivo Público e Histórico de Ribeirão Preto, com datação dos anos 1951 a 1964.

Por sua vez, quando integradas às publicações, no caso os álbuns e almanaques, essas fotografias concretizam a escolha por registrar determinados fatos, práticas e momentos, os quais, passado o tempo, como afirma Boris Kossoy (1989, p. 22), tornam-se a "imagem do real retida pela fotografia (quando preservada ou reproduzida)" fornecendo "o testemunho visual e 
material dos fatos aos espectadores ausentes da cena", tornando-se o que "resta do acontecido, fragmento congelado de uma realidade passada, informação maior de vida e morte, além de ser o produto final que caracteriza a intromissão de um ser fotógrafo num instante dos tempos". (KOSSOY, 1989, p. 22).

De acordo com o gráfico 4 (elaborado a partir do Apêndice D), percebe-se que a assistência médico-odontológica e as cerimônias públicas realizadas pelos parques infantis (lançamento da pedra fundamental, inauguração e solenidades) são os temas recorrentes das fotografias distribuídas nos álbuns e almanaques encontrados. Vale lembrar que, dos sete álbuns e almanaques encontrados (Apêndice C), há um Álbum elaborado especialmente sobre os postos odontológicos do serviço dentário municipal de Ribeirão Preto que realça a assistência médico-odontológica realizada pelos parques infantis do município, fazendo com que o número de fotografias encontradas sobre esse tema seja superior aos demais.

Gráfico 4 - Recorrência temática (álbuns e almanaques)

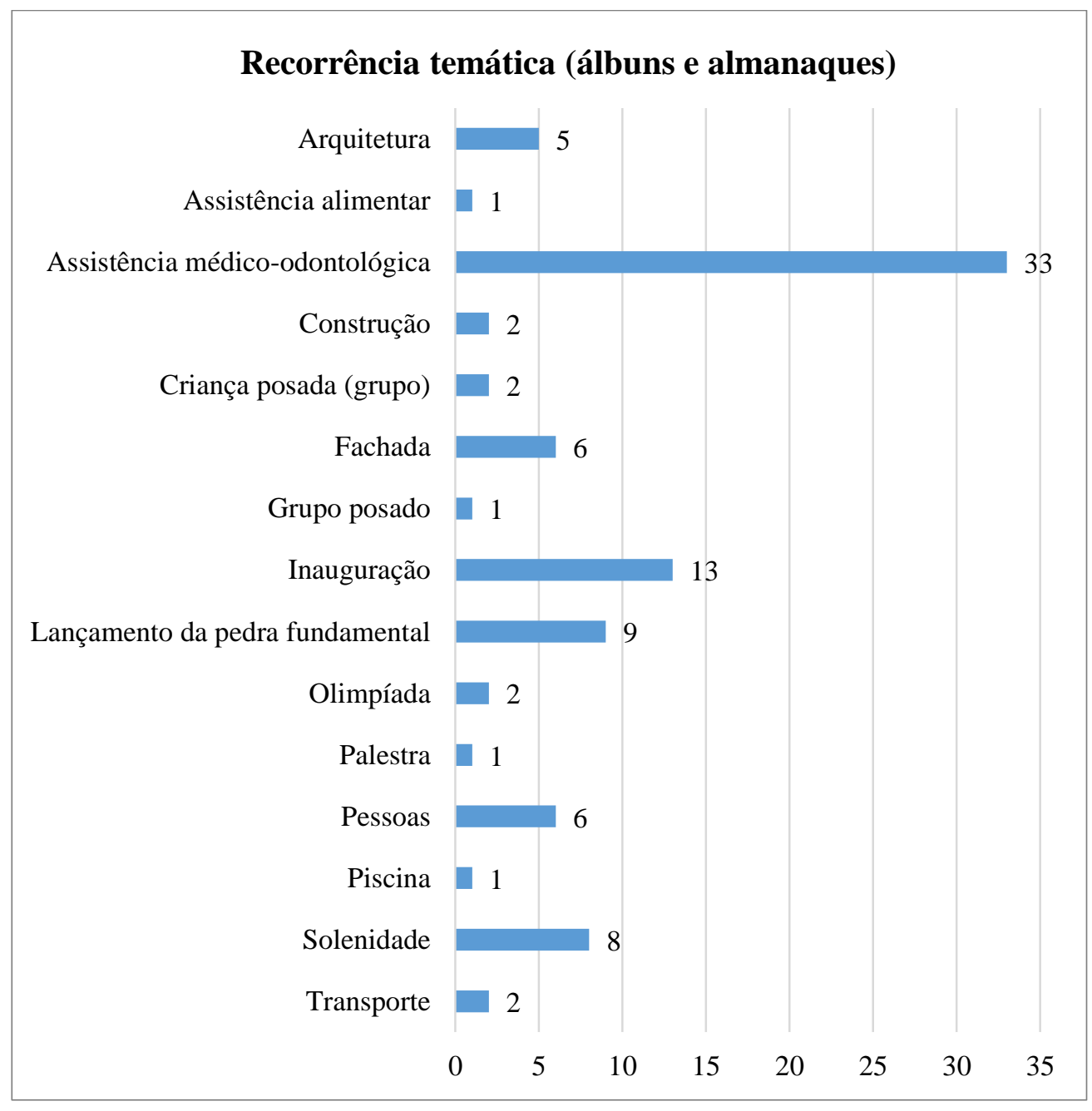

Fonte: produção do próprio autor 
Pode-se notar, conforme o gráfico 5 (elaborado a partir do Apêndice E), que as temáticas abordadas pelas fotografias avulsas depositadas no Arquivo Público e Histórico de Ribeirão Preto são: arquitetura dos parques; assistência alimentar; assistência médico-odontológica; aula de música; banho; barbeiro; brincadeiras; brincadeiras em aparelhos; crianças posadas (grupo); educação física; inauguração dos parques; jogos; leitura; palestra; piscina; e professoras. Assim como o gráfico 4, a inauguração e a assistência médico-odontológica aparecem como temas predominantes nas fotografias. Contudo, imagens de crianças posadas e a assistência alimentar também aparecem como temáticas recorrentes entre essas imagens.

Gráfico 5 - Recorrência temática (fotografias avulsas)

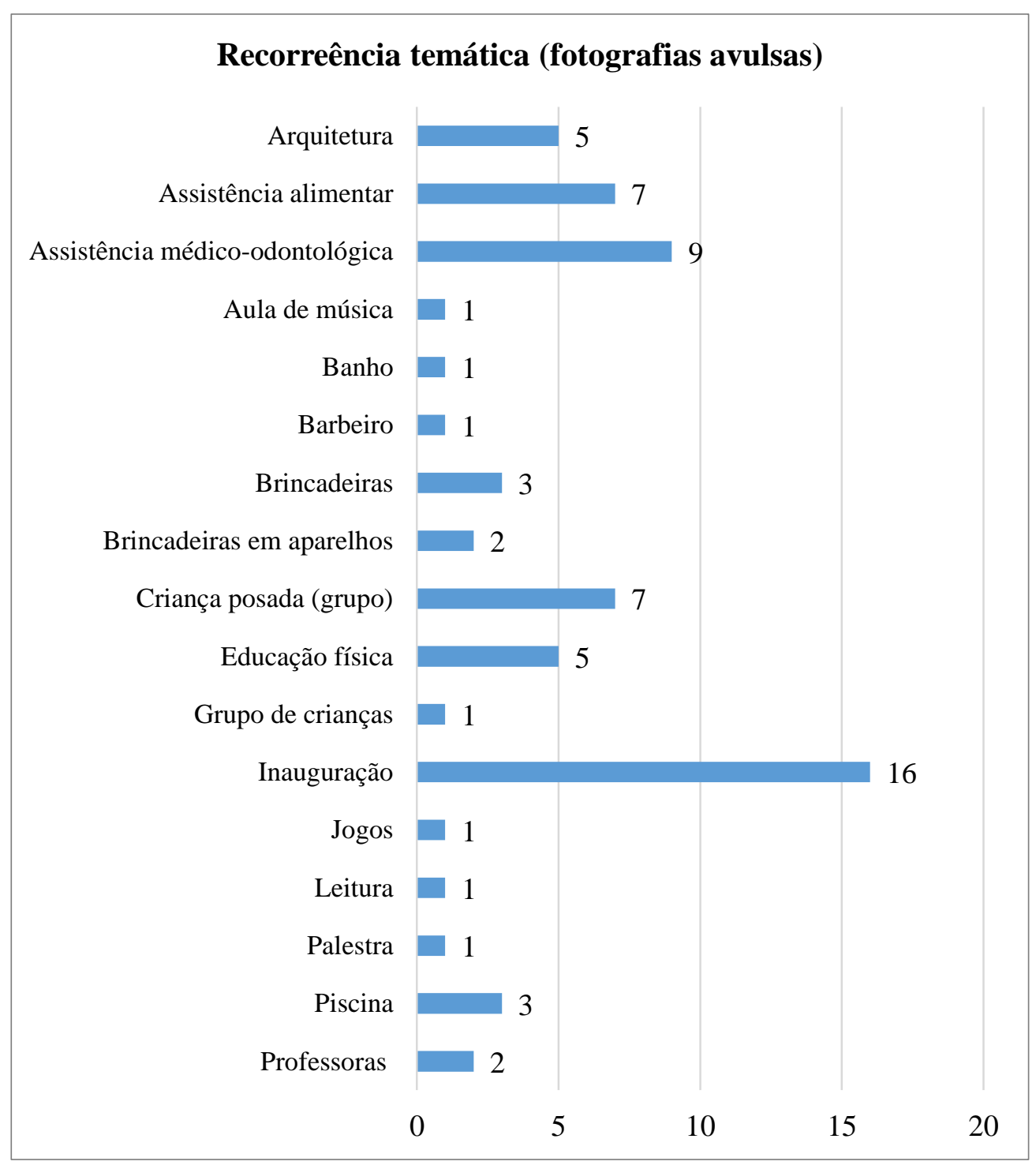

Fonte: produção do próprio autor

A imagem é um artefato cultural que apresenta e representa o mundo. O termo imagem se refere às diversas formas visíveis representadas, por exemplo, em 
desenhos, fotografias, pinturas, charges. A imagem é um produto que revela a visão de mundo, expressa a sensibilidade e a intencionalidade de seu autor na captura de determinado momento da realidade. (SOUZA; OLÁRIA, 2014, p.7).

São visíveis e intencionais, nas fotografias, as maneiras de posicionamento dos personagens retratados, das situações, dos eventos. Ora são fotografadas as rotinas dos parques, a exemplo da recreação, e outras vezes os eventos, como as olimpíadas parqueanas e os desfiles comemorativos. Seja devido à propaganda das rotinas ou da participação dos parques nos diversos festejos municipais, para além do aspecto propagandístico, por isso evidente das imagens fotográficas, é preciso interrogar a intencionalidade de quem as produziu, pois essa pergunta leva a pensar nas motivações por detrás das lentes, naquilo que motivou o olhar fotográfico.

As imagens contam histórias, transformam o passado em nosso
contemporâneo e o presente num grande painel. A fotografia é um relato dos
tempos, uma construção narrativa emoldurada numa série de instantâneos. As
fotografias revelam, sobretudo, o olhar do fotógrafo: aquilo que ele quis
enquadrar, que o jogo de sombra e luz mediado por sua técnica permitiu-lhe
revelar-nos. Mas nós sabemos que o mundo não possui uma moldura. Contar
uma história por meio de fotografias é, portanto, transitar entre o que está
'dentro' da moldura e aquilo que está 'fora', o que não foi captado pelas lentes,
mas que, de alguma maneira, podemos perceber como presente - não importa
se o designarmos por contexto, estrutura ou imaginário. (ALMEIDA, 2006, p.
2).

Percebe-se, a partir do gráfico 6, que o fotógrafo Tony Miyasaka foi quem mais produziu imagens sobre os parques de Ribeirão Preto, com 62 fotos de um total de 66. Na realidade, sua trajetória se entrelaçou com a história de Ribeirão, uma vez que registrou fatos, eventos, personalidades e locais marcantes da história da cidade. 
Gráfico 6 - Número de fotografias (avulsas) por fotógrafolestúdio

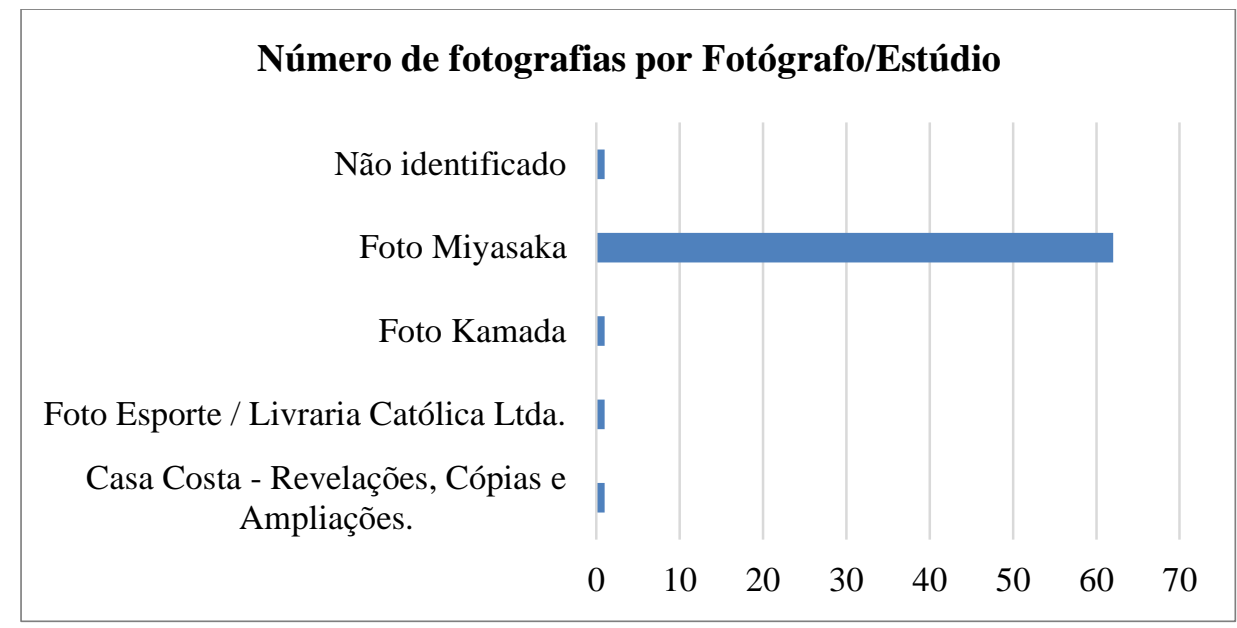

Fonte: produção do próprio autor

De acordo com Crippa e Lastória (2010, p. 62), apesar do trabalho desse fotógrafo ser produto de uma produção comercial, suas fotos são testemunhas do momento em que Ribeirão Preto estava construindo sua identidade como um projeto de modernidade do país, principalmente entre 1949 e 1970. Segundo as autoras, a popularidade das fotografias de Miyasaka "contribuiu, em larga medida, para a construção de uma iconografia de todo o município, transformando-se em emblemas de sua própria identidade”. (CRIPPA; LASTÓRIA, 2010, p. 62).

A produção fotográfica de Miyasaka sobre a cidade de Ribeirão Preto começou com trabalhos de fotorreportagem, em que retratava os ritos da sociedade ribeirão-pretana ${ }^{125}$. De acordo com Crippa e Lastória (2010, p. 71), esse trabalho pioneiro de reportagem fotográfica proporciona hoje "a iconografia que sustenta a construção do imaginário desenvolvimentista e de modernidade realizada no Brasil do pós-guerra, na cidade de Ribeirão Preto”.

A atividade de fotorreportagem levou Tony a desempenhar tarefas para a imprensa local e para a polícia, cobrindo alguns acontecimentos da época. [...]. Alguns relatos familiares lembram quando ele foi obrigado a fugir pelo teto de uma delegacia de polícia, pois uma multidão barrava a entrada, tentando entrar para linchar um homem acusado de estupro. Em outra ocasião, a reportagem fotográfica de Tony Miyasaka ilustrou a notícia, na Folha de São Paulo, de um trágico acidente com vítimas envolvendo um ônibus, na rodovia Anhanguera. (CRIPPA, 2006, p. 11).

${ }^{125}$ De acordo com Crippa (2006, p. 11), "terceiro fator chave para o sucesso da sociedade foi a demanda de um público amplo, em uma sociedade em que à riqueza das indústrias locais logo se junta com o brilho de receber a faculdade de medicina da prestigiosa Universidade de São Paulo ao lado das instituições de ensino superior particulares e, em seguida, as outras faculdades da área de saúde, odontologia e enfermagem”. 
Por trabalhar com fotorreportagem e ter interesse por cinematografia, Miyasaka foi um dos fundadores do Cine Foto Clube de Ribeirão Preto. De acordo com sua filha Elza Miyasaka (2011, p. 4), Miyasaka foi reconhecido rapidamente pela sociedade ribeirão-pretana, trabalhava em jornais e revistas da cidade cobrindo eventos sociais, esportivos e políticos e estava envolvido com intelectuais locais, tais como Bassano Vacarini, Francisco Amêndola, Pedro Manuel Gismonti e Rubens Francisco Luchetti, com os quais fundou o Cine Foto Clube de Ribeirão Preto.

A associação, fundada em 1950, começou "uma nova era na fotografia em Ribeirão Preto, com um grupo que era apaixonado por fotografia. Seu primeiro presidente foi o médico Dr. Paulo Valentie de Oliveira, embora tenha sido idealizado pelo Sr. Eudóxio Marques Manço". (CINE, 2010). O Cine Foto Clube de Ribeirão Preto se consagrou como uma "sociedade civil de direito privado, sem fins lucrativos, com o interesse único de incentivar a arte fotográfica e cinematográfica, participando de exposições e salões nacionais e internacionais, levando o nome de Ribeirão Preto e de seus associados a todos os cantos". (CINE, 2010).

Essa associação de fotógrafos é integrante do movimento fotoclubista, que "surgiu como uma reação amadorista à massificação da produção fotográfica predominante". (COSTA; SILVA, 2004, p. 22). Os fotoclubistas ribeirão-pretanos se uniam para debater e realizar ações em torno de fotografias da cidade e Miyasaka se fez presente nesse clube, levando suas fotografias de Ribeirão Preto para debate e exposições de nível nacional.

Além disso, criou em seu estabelecimento a Seção Cine Foto Reportagem que consistia na realização de trabalhos comerciais. Das 62 fotos que revelou sobre parques infantis, 55 são integrantes da Seção Cine Foto Reportagem que realizou nas décadas 1950 e 1960.

Isso posto, pode-se dizer que Tony Miyasaka foi um fotógrafo modernista com alta popularidade contratado pelas administrações municipais de Ribeirão Preto para disseminar e propagar o desenvolvimento e modernidade da cidade. Dessa maneira, os parques infantis eram considerados instituições modernas de Ribeirão Preto e, com isso, integravam a lista de feitos municipais que deveriam ser eternizados pelo fotógrafo mais prestigiado da região.

Não há informações de texto sobre as imagens encontradas, mas ainda assim estas confirmam a existência dos parques infantis da cidade. No entanto, a imagem isolada não pode ser considerada como documento dotado de valor histórico, como uma prova fidedigna da cultura e do espaço ocupado por essa instituição nas décadas de 50 e 60. 
Tempos da criação e tempo da representação. São os tempos da fotografia. O primeiro fixa o acontecimento e paralisa ilusória e intencionalmente a ação. Se tratar-se de fatos vinculados à nossa história, vai se prestar às rememorações. Se tratar-se de histórias de outras gentes, de outros fatos, de outras épocas, vai se prestar a memória dos outros. Já com o segundo e definitivo tempo, o da representação, convivemos; sejam enquanto lembranças marcantes em nossas vidas (mantidas em meio aos nossos papéis particulares, em nossos porta-retratos), sejam enquanto documentos iconográficos, pois, afinal de contas, trata-se de nossos instrumentos de trabalho e investigação. (KOSSOY, 2007, p. 134).

Assim como as fotografias que Hildegard Rosenthal tirou de São Paulo na década de 1940, as que Miyasaka tirou de Ribeirão Preto nas décadas de 1950 e 1960 "não são meros registros descompromissados com a realidade; ao contrário, são imagens pensadas [...]”. (KOSSOY, 2007, p. 99).

Apesar de direcionadas, as fotografias são carregadas de ambiguidades e sentidos não explícitos. São os elos que permitem o maior contato com a realidade passada. Isso posto, o potencial informativo das fotografias só poderá ser alcançado quando as imagens forem:

[...] [contextualizadas] na trama histórica em seus múltiplos desdobramentos (sociais, políticos, econômicos, religiosos, artísticos, culturais enfim) que circunscreveu no tempo e no espaço o ato da tomada do registro. Caso contrário, essas imagens permanecerão estagnadas em seu silêncio: fragmentos desconectados da memória, meras ilustrações 'artísticas' do passado. (KOSSOY, 2002, p. 22).

Dessa maneira, ao resgatar os desdobramentos políticos, econômicos, religiosos, artísticos e culturais, e, a partir do momento em que a fotografia passa a ter reconhecidamente um autor, que tem um olhar próprio e pensante, assim como um autor de um documento escrito, a fotografia passa a exibir dados e a ter importância dentro da história. Afinal, a imagem "representa as atividades de um grupo social, suas significações específicas, o que possibilita a compreensão das ações humanas em determinados momentos históricos”. (SCHIMITT, 2007, p.11 apud SOUZA; OLÁRIA, 2014, p.7).

[...] devemos considerar que a imagem não representa a realidade plasmada em uma superfície amorfa, mas que é constituída e produzida pela realidade social, que é mediadora entre o sujeito que a produz e aquele a quem se destina, logo, neste texto a imagem é considerada como um artefato cultural. Como artefato cultural, ainda que não seja o real, apresenta, representa ou reapresenta o mundo, tornando presente aquilo ou alguém que está ausente. A imagem, especialmente a fotografia, tem o poder de trazer de volta o ausente, o distante, de materializar aos olhos o que não está materialmente ao alcance das mãos. (WELLER, BASSALO, 2011, p. 286). 
Por isso, um dos caminhos percorridos para a conclusão desse trabalho foi analisar as fotografias dos parques infantis considerando-as como documento histórico e meio para reconstrução da memória dos parques infantis de Ribeirão Preto, pensados a partir dos múltiplos desdobramentos históricos circunscritos na história da cidade, bem como a relação deles com o fotógrafo Tony Miyasaka, afinal, ele era contratado pela prefeitura da cidade para construir uma boa imagem desses parques na imprensa local. 


\section{CONSIDERAÇÕES FINAIS}

A partir das fontes históricas pode-se notar o quanto a imagem pública construída pelas diferentes administrações de Ribeirão Preto impregnou e contribuiu para a construção de uma memória dos parques infantis da cidade. A imagem que aspiravam divulgar, construir e perpetuar era de uma instituição pública que, além de lidar com o lúdico e assim instigar a criança e o adolescente a ir àquele local, era uma instituição em que eles tinham educação e assistência alimentar, médica e odontológica, o que os retirava das ruas.

Afora isso, a disseminação de uma boa imagem pública de uma instituição como o parque infantil também promovia as políticas públicas locais de educação, cultura e higiene realizadas pelas administrações municipais, resultando também numa boa imagem pública dos próprios políticos, ou seja, numa forma de propaganda política. Se divulgada uma imagem negativa dos parques, a mesma negatividade cairia sobre aquelas administrações.

Analisando os jornais, nenhuma publicação negativa a respeito dos parques infantis da cidade foi encontrada. Ao contrário, mesmo quando anunciadas campanhas para arrecadar fundos para os parques, a instituição estava sempre recebendo elogios pelo papel assistencialista que cumpria. Apenas uma notícia no jornal A Tarde, de 17 de março de 1953, trouxe à tona uma crítica à prefeitura da época em relação ao Parque Infantil do Barracão, que havia acabado de ser inaugurado: a carta de um leitor que se dizia contra uma campanha pró-parque infantil, pois era dever da prefeitura, e não da sociedade, assisti-los. Entretanto, o próprio jornal esclareceu, junto à publicação de tal carta, que a cidade estava emergindo e que, com a instalação do parque, foi possível nutrir 700 crianças com frutas e sopas e o surgimento de beneméritos do parque e campanhas ocorreu para alavancar a assistência, e não que a prefeitura deixava de oferecê-los. Dessa maneira, é possível dizer que a imprensa era um meio de os políticos tornarem boa a imagem pública dos parques infantis e com isso suas próprias imagens, ou seja, a imprensa era a voz do poder.

Analisando a documentação iconográfica, percebe-se também que eram imagens oficiais, já que os álbuns foram confeccionados a mando dos prefeitos, principalmente pelo Cel. Alfredo Condeixa Filho; ou elaborados para presenteá-los, como no caso do Álbum Histórico e Fotográfico dos Postos Odontológicos do Serviço Dentário Municipal, feito pela chefe da seção médico-social-odontológica de Ribeirão Preto para presentear o prefeito Cel. Alfredo Condeixa Filho. Nessa documentação, apesar de grande parte ser de autoria do experiente fotógrafo Tony Miyasaka, vê-se explícita a intencionalidade do posicionamento das crianças, professoras e 
funcionários para a lente das câmeras fotográficas. Nas fotografias já expostas nesse trabalho, com exceção daquelas tiradas durante as aulas de educação física e recreação, as crianças estavam sempre quietas, em fila ou em pose para foto. Nota-se também que, apesar dos pés descalços, as crianças estavam sempre com uniforme limpo, branco e liso. De acordo com as professoras entrevistadas por Daharem (2011) e Ferreira (2011), foi possível descobrir que muitas não deixavam as crianças levarem para as suas casas seu uniforme, pois, se o levassem, no dia seguinte ele voltava sujo. Dessa maneira, as próprias professoras e funcionárias cuidavam do uniforme dessas crianças e por isso a roupa estava limpa em todas as fotos. Já os pés descalços são uma forte marca de classe, pois as professoras podiam lavar o uniforme, mas não tinham como oferecer o calçado.

A legislação municipal foi a fonte histórica que permitiu alinhar as informações encontradas na imprensa de 1950 a 1980 com a documentação iconográfica e com a bibliografia referente aos parques da cidade. Com as fontes dialogando é possível afirmar que os parques infantis de Ribeirão Preto eram locais que os governantes, através da mídia, projetavam-se para a sociedade - os parques seriam meio de autopromoção -; mas também eram ambientes em que a prefeitura realmente promovia o bem-estar da infância, especialmente dos pobres; locais que possibilitavam aos pais encontrarem abrigo e educação para os filhos; e locais em que a atividade física era o mote educativo e fiador da saúde e higiene das crianças.

Os parques começaram a ser descaracterizados quando se instalaram Escolas Vocacionais nos parques da cidade na década de 1960. Afinal, as crianças mais velhas que frequentavam o parque no período oposto à escola regular passaram a estudar nas vocacionais, que ofereciam práticas diferenciadas, desenvolvendo determinadas vocações, como práticas educativas de enfermagem, datilografia, noções elementares de eletricidade, pintura em tecido, arte culinária, horticultura, canto, música e línguas.

O segundo fator que os transformou e que faz com que poucos saibam de sua existência ocorreu em 10 de outubro de 1980, quando o prefeito Dr. Antônio Duarte Nogueira assinou a Lei n 3839 (RIBEIRÃO PRETO, 1980a), alterando a denominação dos parques infantis para Escolas Básicas de $1^{\circ}$ Grau. Com isso, os parques tiveram de se adaptar para escolas com classes de recreação infantil, pré-alfabetização e classes de $1^{\circ}$ grau, e todo trabalho diferenciado que era oferecido naqueles locais, principalmente as atividades lúdicas e recreação, diminuiu ou deixou de existir.

De acordo com Maria Malta Campos (2013, p. 27), durante as décadas de 1970 e 1980, as posições baseadas na teoria da privação cultural tiveram grande impacto nas políticas de assistência social e de educação no Brasil. De acordo com a autora, os parques infantis da cidade 
de São Paulo passaram a privilegiar atividades formais de preparação para a alfabetização em salas de aula. Além disso, outros programas de educação compensatória para crianças de baixa renda estavam sendo implantados durante o regime militar. Dessa maneira, é possível dizer que as teorias de privação cultural que vigoraram durante as décadas de 1970 e 1980 influenciaram também no fechamento dos parques de Ribeirão Preto, os quais, na mesma época, antes de serem transformados em Escolas Básicas de $1^{\circ}$ Grau, perderam gradativamente o caráter assistencialista e a relação com a educação sanitária.

Mas ainda resta uma pergunta: por que obliterá-los se um dia foram a instituição educacional de maior prestigio na cidade? Todavia, essa questão cabe a um novo estudo detalhado das documentações oficiais do final dos anos 70 e começo dos 80 ou até mesmo de uma pesquisa utilizando, como metodologia, a história oral. Afinal, existiram vozes que foram silenciadas e que deveriam ser disseminadas? 


\section{REFERÊNCIAS}

A CIDADE. Ribeirão Preto, São Paulo, 1949-1980.

A TARDE. Ribeirão Preto, São Paulo, 1949-1955.

AGUIAR, Augusta (Org.). Álbum histórico e fotográfico dos postos odontológicos do serviço dentário municipal de Ribeirão Preto. Ribeirão Preto, 1963.

ALMEIDA, Marco Antonio de. Tony Miyasaka: um olhar sobre a modernidade de Ribeirão Preto. In: MIYASAKA, T. K.; MIYASAKA, E. L. Ribeirão Preto pelo olhar de Tony Miyasaka. Ribeirão Preto: [s.n.], 2006.

ASSEMBLEIA LEGISLATIVA DO ESTADO DE SÃO PAULO. Welson Gasparini. Disponível em: < http://www.al.sp.gov.br/alesp/deputado/?matricula=300523>. Acesso em: 06 jun. 2015.

BACELLAR, Carlos. Uso e mau uso dos arquivos. In: PINSKY, Carla Bassanezi (Org.). Fontes históricas. 3. ed. São Paulo: Contexto, 2014. p. 23-79.

BLOOM, Philipp. Ter e manter: uma história intima de colecionadores e coleções. Rio de Janeiro: Record, 2003.

BORGES, Maria Elisa Linhares. História e fotografia. 3 ed. Belo Horizonte: Autêntica, 2011.

BRASIL. Projeto de Lei n ${ }^{\circ} 786$, de 7 de maio de 1959. Dispõe sobre a criação do serviço de recreação. Diário Oficial do Estado de São Paulo, 7 maio 1959. Ano LXIX, n. 100, p. 64.

BULFINCH, Thomas. O livro de ouro da mitologia: história de deuses e heróis. Tradução David Jardim. Rio de Janeiro: Ediouro, 2006.

CAMPOS, Maria Malta. Entre as políticas de qualidade e a qualidades das práticas. Cadernos de Pesquisa, v. 43, n. 148, p. 22-43, jan./abr. 2013.

CAMPOS, Raquel Discini de. No rastro de velhos jornais: considerações sobre a utilização da imprensa não pedagógica como fonte para a escrita da história da educação. Revista Brasileira de Educação, Campinas, v. 12, n. 1 (28), p. 45-70, jan./abr. 2012.

CHAUI, Marilena. Convite a filosofia. São Paulo: Afiliada, 2005.

CIAVATTA; Maria; ALVES, Nilda (Org.). A leitura de imagens na pesquisa social: história, comunicação e educação. São Paulo: Cortez, 2004.

CINE FOTO CLUBE RIBEIRÃO PRETO. Nossa história. 2010. Disponível em: <http://www.cinefotoclube.com.br/nossahistoria.html>. Acesso em: 17 set. 2014.

COSTA, Helouise; SILVA, Renato Rodrigues da. A fotografia moderna no Brasil. São Paulo: Cosac Naify, 2004. 
COSTA, João Emboaba da (Org.). Álbum comemorativo do $1^{\circ}$ centenário da fundação da cidade do Ribeirão Preto. Ribeirão Preto, 1956.

CRIPPA, Giulia. A cidade e seu retrato: a modernidade revelada de Tony Miyasaka. In: MIYASAKA, T. K.; MIYASAKA, E. L. Ribeirão Preto pelo olhar de Tony Miyasaka. Ribeirão Preto: [s.n.], 2006.

Os "lugares da memória": dispositivos ideológicos, esquemas tópicos e sistemas classificatórios. In: LARA, Marilda Lopes Ginez de; FUJINO, Asa; NORONHA, Daisy Pires. (Org.). Informação e Contemporaneidade: perspectivas. Recife: NÉCTAR, 2007. p. 121138.

; LASTÓRIA, Andréa Coelho. Um passeio pelas imagens: a Ribeirão Preto de Tony Miyasaka. Educação Temática Digital, Campinas, v. 11, n. 2, p. 54-74, jan./jun. 2010. Disponível em: <http://www.fe.unicamp.br/revistas/ged/etd/article/view/2107/pdf_89>. Acesso em: 13 ago. 2014.

DARAHEM, Gabriela Campos. Contribuição para a história da educação infantil em Ribeirão Preto: experiências de funcionários e professoras das Escolas Municipais de Educação infantil (EMEIs). 2011. Dissertação (Mestrado em Psicologia)-Faculdade de Filosofia, Ciências e Letras de Ribeirão Preto, Universidade de São Paulo, Ribeirão Preto, 2011.

DER. Mapa Rodoviário do Estado de São Paulo. São Paulo, 2002. Disponível em: <http://www.ribeiraoeregiao.com.br/images/regiao_administrativa_ribeirao_preto.jpg>. Acesso em: 11 out. 2014.

DIÁRIO DA MANHÃ. Ribeirão Preto, São Paulo, 1949-1980.

DUMONT. Lei no 114, de 15 de fevereiro de 1968. Denomina de "Deputado Costabile Romano" o parque infantil desta cidade de Dumont. Disponível em: $<$ http://www.camaradumont.sp.gov.br/download/leis/Leis\%201968/Lei\%20114\%20\%20denomina\%20parque\%20infantil.pdf>. Acesso em: 27 maio 2014.

FERREIRA, Débora Menengotti. Memórias do magistério: idealização do passado e exercício da profissão no presente. 2010. 62 f. Iniciação Científica (Programa Ensinar com Pesquisa)-Faculdade de Filosofia, Ciências e Letras de Ribeirão Preto, Universidade de São Paulo, 2010.

FINCOTI, Michele Cristina. Memórias do magistério: idealização do passado e exercício da profissão no presente. 2012. 89 f. Iniciação Científica (Programa Ensinar com Pesquisa)Faculdade de Filosofia, Ciências e Letras de Ribeirão Preto, Universidade de São Paulo, 2012.

GARAVAZZO, Juliana; MARCONDES, Renato Leite. Metamorfoses da economia urbana: os estabelecimentos de um município brasileiro (Ribeirão Preto, 1890-1962). Estudos do Século XX, Coimbra, n. 4, p. 255-272, 2004. 
GASPARINI, Welson. A educação é o melhor caminho. 2014. Disponível em: <http://www.brasilagro.com.br/conteudo/a-educacao-e-o-melhor-caminho-welsongasparini.html>. Acesso em: 06 jul. 2015.

HALBWACHS, Maurice. A memória coletiva. São Paulo: Centauro, 2006.

IBGE. Enciclopédia dos Municípios Brasileiros. XXX volume. 1958. Disponível em: <http://biblioteca.ibge.gov.br/index.php/biblioteca-catalogo?view=detalhes\&id=22 7295>. Acesso em: 9 mar. 2015.

KESSEL, Zilda. Memória e memória coletiva. [s.d.]. Disponível em: <http://www.museudapessoa.net/adm/Upload/291I6110920121916535P032.pdf>. Acesso em: 20 mar. 2013.

KOSSOY, Boris. Fotografia e história. São Paulo: Ática, 1989.

Os tempos da fotografia. Cotia: Ateliê Editorial, 2007.

Realidades e ficções na trama fotográfica. 3. ed. Cotia: Ateliê, 2002.

KRAMER, Sônia. A política do pré-escolar no Brasil: a arte do disfarce. $5^{\mathrm{a}}$ ed. São Paulo: Cortez, 1995.

KUHLMANN JR., Moysés. A educação infantil no século XX. In: STEPHANOU, Maria; BASTOS, Maria Helena Câmara. (Orgs.). História, memória e história da educação. In: (Orgs.). Histórias e memórias da educação no Brasil - vol. III: Século XX. 4. ed. Petrópolis: Vozes, 2011. 3 v. p. 416-429.

Histórias da educação infantil brasileira. Revista Brasileira de Educação, Campinas, n. 14, p. 5-18, 2000. Disponível em: <http://www.scielo.br/pdf/rbedu/n14/n14a02>. Acesso em: 16 set. 2014.

LASTÓRIA, Andrea Coelho. (Org.). Atlas Escolar Histórico, Geográfico e Ambiental de Ribeirão Preto. 1. ed. Ribeirão Preto: 2008. v. 1.140 p. Disponível em: <http://falagrupoelo.blogspot.com.br/p/atlas-escolar-municipal.html>. Acesso em: 10 set. 2014.

LE GOFF, Jacques. História e Memória. Campinas: UNICAMP, 1996.

LIMA, Solange Ferraz de; CARVALHO, Vânia Carneiro de. Fotografia e cidade: da razão urbana à lógica de consumo - álbuns de São Paulo (18887 - 1954). Campinas: Mercado de letras, 1997.

MENESES, Ulpiano T. Bezerra de. A história, cativa da memória? Para um mapeamento da memória no campo das Ciências Sociais. Revista do Instituto de Estudos Brasileiro, São Paulo, v. 34, p. 9-23, 1992.

MICARONI, Silvana. A educação física nos parques infantis da cidade de São Paulo: 1947 a 1957. 2007. Dissertação (Mestrado em Educação)-Universidade São Francisco, Itatiba, 2007. 
MIYASAKA, Elsa L. A imagem retratada em 1950-60 na região de ribeirão preto. In: $2^{\circ}$ Seminário Ibero-Americano Arquitetura e Documentação, 2011, Belo Horizonte. Anais... Belo Horizonte, 2011.

OGROFIT. O que são exercícios calistênicos? 2011. Disponível em:

<http://ogrofit.blogspot.com.br/2011/09/o-que-sao-exercicios-calistenicos.html>. Acesso em: 24 maio 2015.

PINTO, Luciana Suarez Galvão. Crise e ajustamento da economia de Ribeirão Preto: 1930-1956. 1997. Trabalho de conclusão de curso (Graduação em Economia)-Faculdade de Economia, Administração e Contabilidade, Universidade de São Paulo, Ribeirão Preto, 1997.

PREFEITURA MUNICIPAL DE RIBEIRÃO PRETO. EMEI Amélia Junqueira. Disponível em: 〈https://www.ribeiraopreto.sp.gov.br/seducacao/escolas/ajunqueira/i15ajunqueira.php>. Acesso em: 25 maio 2015.

EMEI Ana dos Santos Gabarra. Disponível em:

<https://www.ribeiraopreto.sp.gov.br/seducacao/escolas/gabarra/i15gabarra.php>. Acesso em: 20 maio 2015.

. EMEI Anita Procópio Junqueira. Disponível em:

<https://www.ribeiraopreto.sp.gov.br/seducacao/escolas/anita/i15anita.php>. Acesso em: 25 maio 2015.

. EMEI Áurea Apparecida Braghetto Machado. Disponível em:

<https://www.ribeiraopreto.sp.gov.br/seducacao/escolas/aurea/i15aurea.php>. Acesso em: 20 maio 2015.

EMEI Dona Iria Junqueira. Disponível em:

<https://www.ribeiraopreto.sp.gov.br/seducacao/escolas/iria/i15iria.php >. Acesso em: 20 maio 2015.

. EMEI Marlene Jorge dos Reis. Disponível em:

https://www.ribeiraopreto.sp.gov.br/seducacao/escolas/marlene/i15marlene.php>. Acesso em: 21 maio 2015.

EMEI Professora. Carmem Massarotto. Disponível em:

<https://www.ribeiraopreto.sp.gov.br/seducacao/escolas/masaroto/i15masaroto.php>. Acesso em: 20 maio 2015.

Guia dos museus. 2014. Disponível em: <http://www.youblisher.com/p/911615Guia-de-Museus-2014/>. Acesso em: 16 set. 2014.

. Legislação Municipal. Disponível em:

<http://www.ribeiraopreto.sp.gov.br/leis/pesquisa/j321 pesquisa.htm >. Acesso em: 20 out. 2013.

REGISTRO, Tânia Cristina. Biografias dos governantes de Ribeirão Preto: poder executivo (presidentes da câmara, intendentes e prefeitos). 2013. No prelo. 
RIBEIRÃO PRETO. Decreto nº 004, de 05 de fevereiro de 1963a. Denomina de parque infantil dos Bandeirantes o parque construído na Vila Recreio. Disponível em: $<$ http://www.ribeiraopreto.sp.gov.br/leis/pesquisa/ver.php?id=27787\&chave=parque + infantil >. Acesso em: 19 ago. 2014.

Decreto $n^{\circ}$ 010, de 21 de fevereiro de 1963b. Denomina oficialmente de "Professora Conceição Monteiro de Barros" uma das escolas municipais. Disponível em: $<$ http://www.ribeiraopreto.sp.gov.br/leis/pesquisa/ver.php?id=27807\&chave=parque+infantil $>$. Acesso em: 19 ago. 2014.

Decreto $n^{\circ}$ 067, de 07 de dezembro de 1965a. Desapropria área de terra destinada a construção de parque infantil, no bairro da Lapa. Disponível em: <http://www.ribeiraopreto.sp.gov.br/leis/pesquisa/ver.php?id=28353\&chave=parque+infantil >. Acesso em: 19 ago. 2014.

. Decreto ${ }^{\circ}$ 147, de 26 de dezembro de 1968a. Denomina de "padre Emílio Jarbinet", o parque infantil no bairro da Lapa. Disponível em:

<http://www.ribeiraopreto.sp.gov.br/leis/pesquisa/ver.php?id=27138\&chave=parque+infantil $>$. Acesso em: 19 ago. 2014.

Decreto $\mathrm{n}^{\circ} 168$, de 12 de setembro de 1972a. Declara de utilidade pública área de terreno localizada nesta cidade, no bairro de Vila Tibério, destinada à ampliação do parque infantil de Vila Lobato. Disponível em: <http://www.ribeiraopreto.sp.gov.br/leis/pesquisa /ver.php?id=25261\&chave=parque+infantil $>$. Acesso em: 19 ago. 2014.

Decreto ${ }^{\circ}$ 376, de 01 de dezembro de 1975. Denomina de "Professora Áurea Aparecida Braghetto Machado", o parque infantil do Bairro de Vila Lobato. Disponível em: $<$ http://www.ribeiraopreto.sp.gov.br/leis/pesquisa/ver.php?id=23466\&chave=parque+infantil $>$. Acesso em: 10 out. 2013.

Decreto ${ }^{\circ}$ 098, de 27 de junho de 1974. Abre crédito especial de cr\$ 200.000,00 para construção de um parque infantil no Distrito de Guatapará, em cumprimento à lei municipal no 2903 de 25/06/1974. Disponível em: <http://www.ribeiraopreto.sp.gov.br /leis/pesquisa/ver.php?id=23925>. Acesso em: 10 out. 2013.

. Lei n ${ }^{\circ} 97$, de 01 de julho de 1949. Dispõe sobre estruturação, classificação e a consolidação dos cargos e funções gratificadas dos servidores públicos municipais e dá outras providências. Disponível em: 〈http://cm.jusbrasil.com.br/legislacao/694544/lei-97-49>. Acesso em: 10 jan. 2014.

Lei no 292, de 20 de abril de 1953a. Cria o Parque Infantil da Praça Antônio Prado. Disponível em: <http://www.ribeiraopreto.sp.gov.br/leis/pesquisa/ ver.php?id=29735\&chave=parque+infantil $>$. Acesso em: 10 out. 2013.

. Lei $\mathrm{n}^{\circ} 333$, de 11 de novembro de 1953b. Cria o Parque Infantil do Bosque "Fábio Barreto". Disponível em: <http://www.ribeiraopreto.sp.gov.br/leis/pesquisa/ver.php ?id=28744\&chave=parque+infantil $>$. Acesso em: 10 out. 2013. 
Lei $\mathrm{n}^{\circ} 345$, de 10 de março de 1954. Abre crédito especial para construção de parque infantil em Vila Virginia. Disponível em: <http://www.ribeiraopreto.sp.gov.br/leis/ pesquisa/ver.php?id=28804\&chave=parque+infantil $>$. Acesso em: 10 out. 2013.

. Lei $\mathrm{n}^{\circ} 421$, de 20 de junho de 1955a. Declara de utilidade pública, terreno para construção do parque infantil de Vila Tibério. Disponível em: <http://www.ribeiraopreto.sp. gov.br/leis/pesquisa/ver.php?id=29113\&chave=parque+infantil >. Acesso em: 10 out. 2013.

Lei ${ }^{\circ} 425$, de 11 de julho de 1955b. Cria o Parque Infantil do Distrito de Bonfim Paulista. Disponível em: <http://www.ribeiraopreto.sp.gov.br/leis/pesquisa/ver.php ?id=29120\&chave=parque+infantil $>$. Acesso em: 10 out. 2013.

. Lei no 443, de 05 de julho de 1955c. Denomina o Parque Infantil do Barracão de "Peixe Abbade". Disponível em: <http://www.ribeiraopreto.sp.gov.br/leis/pesquisa/ver.php ?id=29161\&chave=parque+infantil $>$. Acesso em: 10 out. 2013.

. Lei $n^{\circ}$ 547, de 26 de fevereiro de 1957a. Cria Parque Infantil no bairro de Vila Tibério. Disponível em: <http://www.ribeiraopreto.sp.gov.br/leis/pesquisa/ver.php?id $=28766 \&$ chave $=$ parque + infantil $>$. Acesso em: 10 out. 2013 .

Lei $\mathrm{n}^{\circ}$ 588, de 17 de agosto de 1957b. Denomina o Parque Infantil de Vila Tibério de "Da . Anita Procópio Junqueira". Disponível em: <http://www.ribeiraopreto .sp.gov.br/leis/pesquisa/ver.php?id=28894\&chave=parque+infantil >. Acesso em: 18 mar. 2014.

Lei no 721, de 27 de junho de 1958a. Aquisição de ônibus para transportes de estudantes dos distritos e crianças dos parques infantis. Disponível em:

<http://cm.jusbrasil.com.br/legislacao/694024/lei-721-58>. Acesso em: 20 mar. 2014.

. Lei $n^{\circ} 774$, de 11 de novembro de 1958b. Cria Parque Infantil Municipal de Vila Virgínia. Disponível em: <http://cm.jusbrasil.com.br/legislacao/693972/lei-774-58>. Acesso em: 10 abr. 2014.

. Lei $\mathrm{n}^{\circ}$ 820, de 06 de março de 1959a. Denomina Parque Infantil "Santa Maria Goretti”. Disponível em: <http://www.ribeiraopreto.sp.gov.br/leis/pesquisa/ver.php?id=30233 \&chave=parque+infantil >. Acesso em: 10 abr. 2014.

. Lei $\mathrm{n}^{\circ} 857$, de 18 de setembro de 1959b. Autoriza construção de piscina no parque infantil "Maria Goretti", em Vila Virginia. Disponível em: <http://www.ribeirao preto.sp.gov.br/leis/pesquisa/ver.php?id=30531\&chave=parque+infantil>. Acesso em: 10 out. 2013.

. Lei $\mathrm{n}^{\circ}$ 890, de 03 de dezembro de 1959c. Cria Parque Infantil de Vila Paulista. Disponível em: <http://www.ribeiraopreto.sp.gov.br/leis/pesquisa/ver.php?id=305 21\&chave=parque+infanti $>$. Acesso em: 10 out. 2013.

. Lei no 1274, de 27 de dezembro de 1962a. Cria um Parque Infantil no bairro de Santa Cruz do José Jacques. Disponível em: <http://www.ribeiraopreto.sp.gov.br /leis/pesquisa/ver.php?id=28534\&chave=parque+infantil >. Acesso em: 19 ago. 2014 . 
Lei $\mathrm{n}^{\mathrm{o}}$ 1276, de 27 de dezembro de 1962b. Autoriza despender até cr\$ 5.000.000,00, para construção de um Parque Infantil no bairro de Vila Paulista. Disponível em: <http://www.ribeiraopreto.sp.gov.br/leis/pesquisa/ver.php?id=28536\&chave=parque +infantil>. Acesso em: 19 ago. 2014.

. Lei n ${ }^{\circ} 1282$, de 21 de fevereiro de 1963c. Autoriza a construção de um parque infantil no bairro da Lapa. Disponível em: <http://www.ribeiraopreto.sp.gov.br/leis/ pesquisa/ver.php?id=28544\&chave=parque+infantil>. Acesso em: 19 ago. 2014.

Lei n ${ }^{\circ} 1291$, de 08 de abril de 1963d. Cria o Parque Infantil de Vila Recreio. Disponível em: <http://www.ribeiraopreto.sp.gov.br/leis/pesquisa/ver.php?id=28569\&chave =parque+infantil>. Acesso em: 19 ago. 2014.

. Lei n ${ }^{\circ} 1431$, de 20 de julho de 1964a. Autoriza aquisição, mediante concorrência pública, de um ônibus para transporte de crianças dos parques infantis. Disponível em: <http://cm.jusbrasil.com.br/legislacao/693315/lei-1431-64>. Acesso em: 20 dez. 2013.

Lei n ${ }^{\circ} 1474$, de 10 de novembro de 1964b. Autoriza, mediante concorrência, a gravação do hino a Ribeirão Preto. Disponível em: <http://cm.jusbrasil.com.br/legislacao /693272/lei-1474-64>. Acesso em: 10 out. 2014.

. Lei $\mathrm{n}^{\circ} 1475$, de 10 de novembro de 1964c. Autoriza construção de um Parque Infantil em Vila Abranches. Disponível em: <http://www.ribeiraopreto.sp.gov.br/leis/pesquisa /ver.php?id=28075\&chave=parque+infantil $>$. Acesso em: 10 out. 2014.

. Lei $\mathrm{n}^{\circ} 1507$, de 01 de dezembro de 1964d. Cria um Parque Infantil em Vila Seixas. Disponível em: <http://www.ribeiraopreto.sp.gov.br/leis/pesquisa/ver.php?id=28 $188 \&$ chave $=$ parque + infantil $>$. Acesso em: 10 out. 2014.

Lei $\mathrm{n}^{\mathrm{o}} 1618$, de 30 de agosto de 1965b. Autoriza a prefeitura municipal a adquirir, mediante concorrência pública, dois ônibus para o transporte de crianças dos parques infantis. Disponível em: <http://cm.jusbrasil.com.br/legislacao/693125/lei-1618-65>. Acesso em: 15 dez. 2013.

. Lei no 1787, de 31 de maio de 1966a. Dispõe sôbre vacinação anti-tetânica dos alunos matriculados nos parques infantis e escolas e cursos mantidos pelo município. Disponível em: <http://www.ribeiraopreto.sp.gov.br/leis/pesquisa/ver.php?id=27381\&chave =parque+infantil>. Acesso em: 15 out. 2013.

Lei n ${ }^{\circ} 1869$, de 27 de dezembro de 1966b. Cria uma Escola Primária Vocacional Municipal. Disponível em: <http://www.ribeiraopreto.sp.gov.br/leis/pesquisa/j321 pesquisa. $\mathrm{htm}>$. Acesso em: 25 maio 2015.

. Lei $\mathrm{n}^{\circ}$ 2039, de 15 de janeiro de 1968b. Denomina de "Da. Iria Junqueira", o parque infantil de Bonfim Paulista. Disponível em: <http://www.ribeiraopreto.sp.gov.br /leis/pesquisa/ver.php?id=26714\&chave=parque+infantil $>$. Acesso em: 19 ago. 2014 .

Lei $\mathrm{n}^{\circ} 2658$, de 18 de julho de 1972b. Distribuição de leite pasteurizado, a crianças de até 12 anos de idade, através do departamento de promoção social da prefeitura, 
na forma que especifica. Disponível em: <http://cm.jusbrasil.com.br/legislacao/692088/lei2658-72>. Acesso em: 10 out. 2013.

. Lei $\mathrm{n}^{\circ} 2756$, de 14 de maio de 1973a. Cria um Parque Infantil no bairro Vila Lobato. Disponível em: <http://www.ribeiraopreto.sp.gov.br/leis/pesquisa/ver.php?id= 24511\&chave=parque+infantil $>$. Acesso em: 10 out. 2013.

Lei n ${ }^{\circ} 2778$, de 23 de agosto de 1973b. Transforma a Escola Vocacional "Carmem Massarotto" em "Unidade Municipal de Ensino de $1^{\circ}$ Grau". Disponível em: <http://www.ribeiraopreto.sp.gov.br/leis/pesquisa/j321 pesquisa.htm>. Acesso em: 25 maio 2015.

. Lei $\mathrm{n}^{\circ} 3334$, de 06 de julho de 1977a. Cria um Parque Infantil na Vila da Fraternidade. Disponível em: <http://www.ribeiraopreto.sp.gov.br/leis/pesquisa/ver.php?id= 22098\&chave=parque+infantil $>$. Acesso em: 13 nov. 2013.

. Lei n $^{\circ} 3395$, de 19 de dezembro de 1977b. Cria um Parque Infantil no bairro de Jardim Independência. Disponível em: <http://cm.jusbrasil.com.br/legislacao/691355/lei3395-77>. Acesso em: 13 nov. 2013.

Lei no 3618, de 17 de maio de 1979. Dispõe sobre a criação de parque infantil em Vila Albertina e dá outras providências. Disponível em: <http://www.ribeiraopreto. sp.gov.br/leis/pesquisa/ver.php?id=21233\&chave=parque+infantil > . Acesso em: 13 nov. 2013.

Lei ${ }^{\circ} 3839$, de 10 de outubro de 1980a. Altera a denominação dos parques infantis para escolas básicas de $1^{\circ}$ grau. Disponível em: <http://cm.jusbrasil.com.br/ legislacao/690912/lei-3839-80>. Acesso em: 10 nov. 2013.

. Lei $\mathrm{n}^{\circ} 3889$, de 15 de dezembro de 1980 b. Unifica escolas municipais e transfere da classe de bens de uso comum para a de uso especial à área correspondente à Praça "Antônio Prado". Disponível em: <http://cm.jusbrasil.com.br/legislacao/690862/lei-3889-80>. Acesso em: 8 out. 2014.

. Lei $n^{\circ} 4696$, de 24 de outubro de 1985. Altera a denominação das escolas básicas de primeiro grau para escolas municipais de educação infantil. Disponível em: <http://www.ribeiraopreto.sp.gov.br/leis/pesquisa/j321 pesquisa.htm>. Acesso em: 21 maio 2014.

. Lei no 5747, de 15 de junho de 1990. Altera denominação da "E.M.E.I.

Bandeirantes", para "Professora Marlene Jorge Reis". Disponível em: $<$ http://www.ribeiraopreto.sp.gov.br/leis/pesquisa/ver.php?id=28569\&chave=parque+infantil >. Acesso em: 19 ago. 2014.

SANTOS, Plínio Travassos dos. Relatório do Departamento de Cultura de Ribeirão Preto de 1951. Ribeirão Preto, 1952. 23 p.

SÃO PAULO. Ato n. 767, de 9 de janeiro de 1935. Cria o Serviço Municipal de Jogos e Recreio para crianças. Disponível em: <http://portalsme.prefeitura.sp.gov.br/Projetos /memorial/Documentos/ATOS/ACTO\%20N.\%C2\%BA767.pdf>. Acesso em: 22 set. 2014. 
SÃO PAULO (Estado). Lei no 8050, de 31 de dezembro de 1963. Disponível em: <http://governo-sp.jusbrasil.com.br/legislacao/224131/lei-8050-63\#art-12>. Acesso em: 11 out. 2014.

. Lei $\mathrm{n}^{\circ}$ 6645, de 9 de janeiro de 1990. Dispõe sobre alterações no Quadro Territorial Administrativo do Estado. Disponível em: <http://governosp.jusbrasil.com.br/legislacao/185311/lei-6645-90>. Acesso em: 11 out. 2014.

SILVA, Carolina da Costa e. O álbum "Parques Infantis" como objeto cultural: (São Paulo, 1937). 2008. 202 f. Dissertação (Mestrado em Educação)-Faculdade de Educação, Universidade de São Paulo, São Paulo, 2008.

SILVA, Kalina Vanderlei; SILVA, Maciel Henrique. Dicionário de conceitos históricos. 2 ed. São Paulo: Contexto, 2009.

SIMÕES, Paula Guimarães. A potencialidade do conceito de acontecimento para a análise da imagem pública. Líbero, São Paulo, v. 14, n. 28, p. 129-140, dez. 2011.

SOUZA, Maria José Sampaio. Os parques infantis. In: COSTA, João Emboaba da (Org.). Álbum comemorativo do $1^{\circ}$ centenário da fundação da cidade do Ribeirão Preto. Ribeirão Preto, 1956.

SOUZA; Vânia Lucas Costa Alves; OLÁRIA, Vânia. Outros olhares sobre o uso da imagem em pesquisa qualitativa: exercício com a interpretação de Didi Huberman. Comun. \& Inf., Goiânia, v. 17, n. 2, p. 06-22, jul./dez. 2014.

STEPHANOU, Maria; BASTOS, Maria Helena Câmara. (Orgs.). História, memória e história da educação. In: (Orgs.). Histórias e memórias da educação no Brasil - vol. III: Século XX. 4. ed. Petrópolis: Vozes, 2011. 3 v. p. 416-429.

VASCONCELLOS, Maria da Penha C. Memórias da saúde pública: a fotografia como testemunha. São Paulo: Hucitec, 1995.

WELLER, Wivian; BASSALO, Lucélia de M. Braga. Imagens: documentos de visões de mundo. Sociologias, Porto Alegre, ano 13, n. 28, set./dez. 2011. 


\title{
APÊNDICE
}

\author{
APÊNDICE A - Bibliografia sobre os parques infantil da cidade de São Paulo e do interior \\ do Estado.
}

1. ABDANUR, Elizabeth. Parques infantis de Mário de Andrade. Revista do Instituto de Estudos Brasileiros, São Paulo, n. 36, p. 263-270, 1994.

2. ANDRADE, Cleide Lugarini de. A contribuição de Mário de Andrade para a saúde pública no estabelecimento de um projeto de educação destinado a crianças e jovens no Departamento municipal de cultura da cidade de SP. 2008. 212 f. Tese (Doutorado em Saúde Pública)Universidade de São Paulo, São Paulo, 2008.

3. ARANTES, Ana Cristina. Mário de Andrade: o precursor dos parques infantis em São Paulo. 2005. Disponível em: <http://www.anacrisarantes.pro.br/trabalhos/mario\%20de\%20andrade\%20o $\% 20$ precursor\%20dos\%20parques $\% 20$ infantis $\% 20 \mathrm{em} \% 20$ sao\%20paulo.pdf >. Acesso em: 22 abr. 2014.

4. DALBEN, André. Educação do corpo e vida ao ar livre: natureza e educação física em São Paulo (1930 - 1945). 2009. 172 f. Dissertação (Mestrado em Educação Física)-Faculdade de Educação Física, Universidade Estadual de Campinas, Campinas, 2009.

5. DANAILOF, Kátia. Crianças na trama urbana: as práticas corporais nos parques infantis da São Paulo dos anos 1930. 2006. 195 f. Tese (Doutorado em Educação)-Faculdade de Educação, Universidade Estadual de Campinas, Campinas, 2006.

6. DUARTE, Adriano Luiz. Moralidade pública e cidadania: a educação nos anos 30 e 40. Educação \& Sociedade, ano XXI, n. 73, dez. 2000.

7. GUEDES, Lizandra. Novas velhas formas de dominação: os parques infantis e o novo projeto de dominação social. 2006. 179 f. Dissertação (Mestrado em Psicologia)-Instituto de Psicologia, Universidade de São Paulo, São Paulo, 2006. 
8. FARIA, Ana Lúcia Goulart de. A contribuição dos parques infantis de Mário de Andrade para a construção de uma pedagogia da educação infantil. Educação \& Sociedade, Campinas, v. 20, n. 69, p. 60-91, 1999.

9. FARIA, Ana Lúcia Goulart de. Origens da rede pública municipal de educação infantil na cidade de São Paulo: o Departamento de Cultura e os parques infantis de Mário de Andrade (1935-1938). Pro-Posições, v. 6, n. 2[17], p. 34-45, jun. 1995.

10. FILIZZOLA, Ana Carolina Bonjardim. A organização e a disciplinarização do lazer da infância operária nos parques infantis da cidade de São Paulo, na década de 1930. 2002. Disponível em: <http://sbhe.org.br/novo/congressos/cbhe2/pdfs/Tema7/7107.pdf>. Acesso em: 16 ago. 2014.

11. FILÓCOMO, Daniela. A gênese da educação especial: a contribuição dos parques infantis da cidade de São Paulo: 1947 a 1957. 2005. 107 f. Dissertação (Mestrado em Educação)-Universidade São Francisco, Itatiba, 2005.

12. FONSECA, João Pedro da. O cinquentenário dos parques infantis de São Paulo: 1935-1985. Revista da Faculdade de Educação, São Paulo, v. 11, n.1-2, p. 135-148, jan/dez.1985.

13. KUHLMANN JR., Moysés. Histórias da educação infantil brasileira. Revista Brasileira de Educação, Campinas, n. 14, p. 5-18, 2000. Disponível em: <http://www.scielo.br/pdf/rbedu/n14/n14a02>. Acesso em: 16 set. 2014.

14. LEME, Fernanda de Lucca. Memórias de um parque infantil em Campinas: vestígios do pensamento de Mário de Andrade. 2008. 94 f. Dissertação (Mestrado em Educação)-Faculdade de Educação, Universidade Estadual de Campinas, Campinas, 2008.

15. MICARONI, Silvana. A educação física nos parques infantis da cidade de São Paulo: 1947 a 1957. 2007. Dissertação (Mestrado em Educação)Universidade São Francisco, Itatiba, 2007.

16. MIRANDA, Nicanor. Origem e propagação dos parques infantis e parques de jogos. Departamento de Cultura, São Paulo, 1941. 
17. NIEMEYER, Carlos Augusto. A criação de espaços públicos de lazer organizado como expressão de cidadania: o caso dos parques infantis de São Paulo (1934-1954). 2001. Dissertação (Mestrado em Estruturas Ambientais Urbanas)-Faculdade de Arquitetura e Urbanismo da Universidade de São Paulo, São Paulo, 2001.

18. OLIVEIRA, Waldemar de. Os parques de recreação em São Paulo. Revista do Arquivo Municipal, v. XXXV, p. 272-274, mai. 1937.

19. PAULA, Roberta Cristina de. Quem foi que disse que não vivo satisfeito? Eu danço! Encontros com as danças na obra de Mário de Andrade. 2012. 234 f. Dissertação (Mestrado em Educação)-Faculdade de Educação, Universidade Estadual de Campinas, Campinas, 2012.

20. PEREIRA, Mônica. O Parque Infantil "Leonor Mendes de Barros" da cidade de Araraquara (1941-1971). 2008. 40 f. Trabalho de Conclusão de Curso (Licenciatura em Pedagogia)-Departamento de Educação, Universidade Federal de São Carlos, São Carlos, 2008.

21. SANTOS, Maria Walburga dos. Educadoras de parques infantis em São Paulo: aspectos de sua formação e prática entre os anos de 1935 e 1955. 2005. 299f. Dissertação (Mestrado em História e Histografia da EducaçãoFaculdade de Educação, Universidade de São Paulo, São Paulo, 2005.

22. SILVA, Carolina da Costa e. O álbum "Parques Infantis" como objeto cultural: (São Paulo, 1937). 2008. 202 f. Dissertação (Mestrado em Educação)-Faculdade de Educação, Universidade de São Paulo, São Paulo, 2008.

23. TONOLLI, Maria Fernanda Simões. As origens da educação pré-escolar pública municipal em Campinas: o Parque Infantil da Vila Industrial. 1996. 95 f. Trabalho de Conclusão de Curso (Licenciatura em Pedagogia)Universidade de Campinas, Campinas, 1996.

24. VIEIRA, S. A. B. Os parques infantis da cidade de São Paulo (1935-1938): análise do modelo didático-pedagógico. Revista de Iniciação Científica da FFC, Marília, v. 4, n. 1, 2004. 
APÊNDICE B - Quadro com as encadernações dos jornais depositados no Arquivo Público e Histórico de Ribeirão Preto ${ }^{126}$

\begin{tabular}{|c|c|c|c|c|c|c|c|c|}
\hline \multirow{2}{*}{$\begin{array}{l}\text { Jornal/ } \\
\text { Ano }\end{array}$} & A CIDADE & \begin{tabular}{|c|} 
DIÁRIO DA \\
MANHA
\end{tabular} & A TARDE & O DIÁRIO & $\begin{array}{l}\text { DIÁRIO } \\
\text { OFICIAL }\end{array}$ & GAZETA & PASQUIM & $\begin{array}{c}\text { DIÁRIO DE } \\
\text { NOTÍCIA }\end{array}$ \\
\hline & \begin{tabular}{|c|}
$(1905-2004)$ \\
\end{tabular} & \begin{tabular}{|l|} 
(1941-1985) \\
\end{tabular} & (1936-1955) & \begin{tabular}{|l|}
$(1959-1991)$ \\
\end{tabular} & (1960-2006) & (1954-2008) & \begin{tabular}{|l|}
$(1969-1978)$ \\
\end{tabular} & \begin{tabular}{|l|}
$(1949-1983)$ \\
\end{tabular} \\
\hline 1947 & & 1 & 4 & & & & & \\
\hline 1948 & & & 4 & & & & & \\
\hline 1949 & 4 & 2 & 4 & & & & & 1 \\
\hline 1950 & 4 & 4 & 4 & & & & & \\
\hline 1951 & 3 & 3 & 4 & & & & & 1 \\
\hline 1952 & & 2 & 4 & & & & & \\
\hline 1953 & 1 & 2 & 3 & & & & & \\
\hline 1954 & 2 & 1 & 1 & & & 1 & & \\
\hline 1955 & 3 & 4 & 3 & & & & & \\
\hline 1956 & 1 & 4 & & & & 1 & & \\
\hline 1957 & 1 & 2 & & & & & & \\
\hline 1958 & & 1 & & & & & & \\
\hline 1959 & 1 & 7 & & não consulta & & & & 1 \\
\hline 1960 & & 2 & & & 1 & & & \\
\hline 1961 & & 2 & & & & & & \\
\hline 1962 & & 3 & & & & & & \\
\hline 1963 & & 1 & & & & & & \\
\hline 1964 & & 2 & & & & & & \\
\hline 1965 & & 4 & & & 1 & & & \\
\hline 1966 & & 4 & & & & & & \\
\hline 1967 & & 2 & & & & & & \\
\hline 1968 & & & & & & & & \\
\hline 1969 & & & & & & & 1 & \\
\hline 1970 & 1 & 5 & & & & & 1 & \\
\hline 1971 & 1 & 4 & & & & & 1 & \\
\hline 1972 & & 5 & & 4 & & & 1 & 1 \\
\hline 1973 & 5 & 4 & & 10 & 1 & & & $\mathbf{1}$ \\
\hline 1974 & & 3 & & & 1 & & 1 & 1 \\
\hline 1975 & 1 & 4 & & 2 & 1 & & & 1 \\
\hline 1976 & 1 & 2 & & & 1 & & & 1 \\
\hline 1977 & 2 & 7 & & 10 & 1 & & & 12 \\
\hline 1978 & 10 & 7 & & 12 & 1 & & 1 & 12 \\
\hline 1979 & 1 & 6 & & 12 & 1 & & & 12 \\
\hline 1980 & 1 & 1 & & 7 & 1 & & & 1 \\
\hline
\end{tabular}

${ }^{126}$ Os números são a quantidade de encadernações de cada jornal naquele ano. 
APÊNDICE C - Quadro com o álbuns e almanaques depositados no Arquivo Público e Histórico de Ribeirão Preto que citam os parques infantis da cidade

\begin{tabular}{|c|c|c|c|c|c|c|c|}
\hline 을 & $\sum_{\Sigma}$ & $\sum_{\Sigma}$ & $\sum_{\Sigma}$ & $\begin{array}{l}\frac{\pi}{\pi} \\
\frac{\pi}{0} \\
0 \\
0\end{array}$ & \begin{tabular}{|l|}
$\frac{\pi}{4}$ \\
$\frac{.}{0}$ \\
0 \\
0
\end{tabular} & \begin{tabular}{|l|}
$\frac{\pi}{4}$ \\
$\frac{\pi}{0}$ \\
0 \\
0 \\
\end{tabular} & 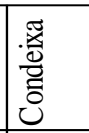 \\
\hline 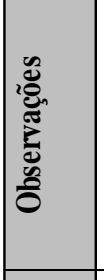 & 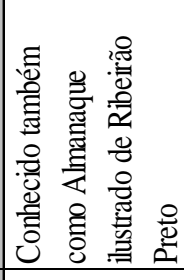 & 产 & 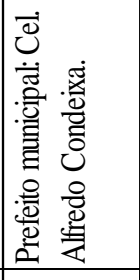 & & & & \\
\hline 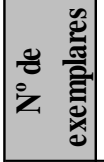 & - & $a$ & - & - & - & - & - \\
\hline 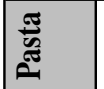 & & $m$ & ন & & & & \\
\hline 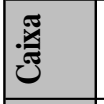 & & i & 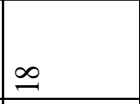 & & & & \\
\hline 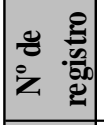 & & ह & $\stackrel{2}{n}$ & & & & \\
\hline 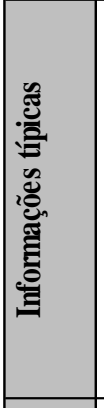 & 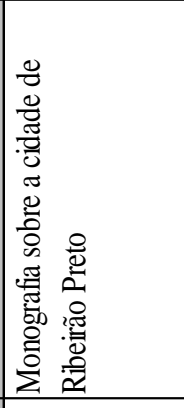 & 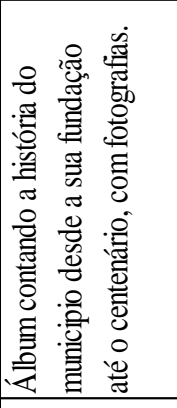 & 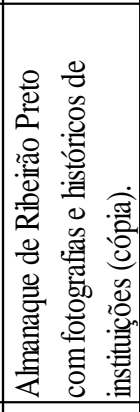 & 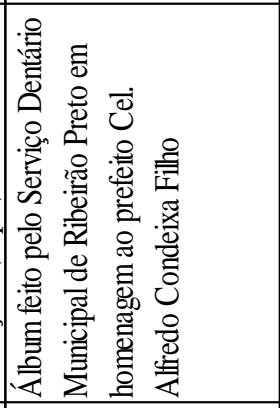 & & & \\
\hline 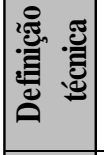 & 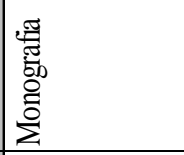 & 竞 & 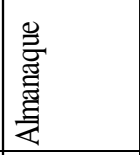 & 苇 & 言 & 志 & 志 \\
\hline 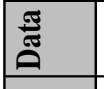 & $\check{2}$ & $\stackrel{\circ}{\varrho}$ & $\check{\varrho}$ & $\hat{\varrho}$ & 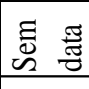 & 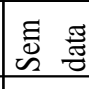 & 靑 \\
\hline 言 & 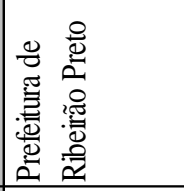 & 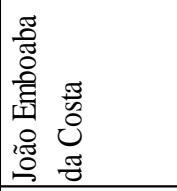 & 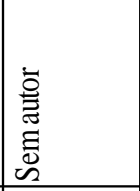 & 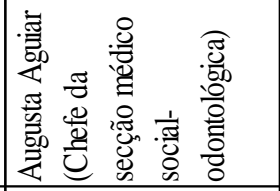 & 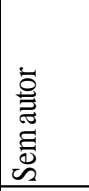 & 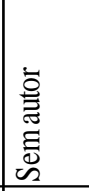 & 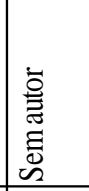 \\
\hline 总 & 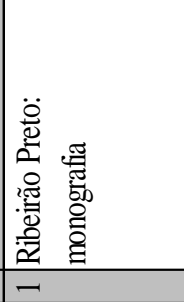 & 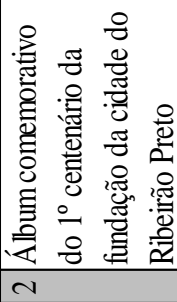 & 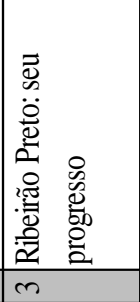 & 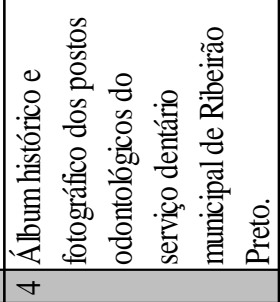 & 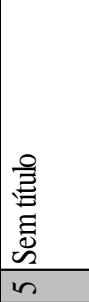 & 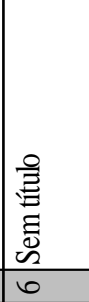 & 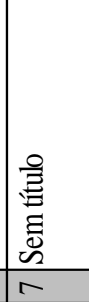 \\
\hline & - & & $m$ & 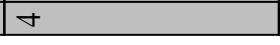 & $\ln$ & 6 & $\pi$ \\
\hline
\end{tabular}


APÊNDICE D - Quadro com as temáticas das fotografias dos álbuns e almanaques depositados no Arquivo Público e Histórico de Ribeirão Preto

\begin{tabular}{|c|c|c|c|}
\hline & Álbum/Almanaque & Fotografias & Temáticas \\
\hline 1 & $\begin{array}{l}\text { Ribeirão Preto: } \\
\text { monografia }\end{array}$ & $\begin{array}{l}\text { A1 Parque Infantil Municipal à } \\
\text { Praça Almeida Prado, em } \\
\text { construção }\end{array}$ & Arquitetura \\
\hline 2 & $\begin{array}{l}\text { Álbum } \\
\text { comemorativo do } 1^{\circ} \\
\text { centenário da } \\
\text { fundação da cidade } \\
\text { do Ribeirão Preto }\end{array}$ & A2 Transporte & Transporte \\
\hline 3 & $\begin{array}{l}\text { Álbum } \\
\text { comemorativo do } 1^{\circ} \\
\text { centenário da } \\
\text { fundação da cidade } \\
\text { do Ribeirão Preto }\end{array}$ & A2 Transporte Vila Tibério & Transporte \\
\hline 4 & $\begin{array}{l}\text { Álbum } \\
\text { comemorativo do } 1^{\circ} \\
\text { centenário da } \\
\text { fundação da cidade } \\
\text { do Ribeirão Preto }\end{array}$ & A2 Piscina Peixe Abbade & Piscina \\
\hline 5 & $\begin{array}{l}\text { Álbum histórico e } \\
\text { fotográfico dos } \\
\text { postos } \\
\text { odontológicos do } \\
\text { serviço dentário } \\
\text { municipal de } \\
\text { Ribeirão Preto. }\end{array}$ & $\begin{array}{l}\text { A4 Fachada Parque Infantil Vila } \\
\text { Recreio }\end{array}$ & Fachada \\
\hline 6 & $\begin{array}{l}\text { Álbum histórico e } \\
\text { fotográfico dos } \\
\text { postos } \\
\text { odontológicos do } \\
\text { serviço dentário } \\
\text { municipal de } \\
\text { Ribeirão Preto. }\end{array}$ & $\begin{array}{l}\text { A4 Fachada Parque Infantil Vila } \\
\text { Virginia }\end{array}$ & Fachada \\
\hline
\end{tabular}




\begin{tabular}{|c|c|c|c|}
\hline 7 & $\begin{array}{l}\text { Álbum histórico e } \\
\text { fotográfico dos } \\
\text { postos } \\
\text { odontológicos do } \\
\text { serviço dentário } \\
\text { municipal de } \\
\text { Ribeirão Preto. }\end{array}$ & $\begin{array}{l}\text { A4 Fachada Parque Infantil Vila } \\
\text { Tibério }\end{array}$ & Fachada \\
\hline 8 & $\begin{array}{l}\text { Álbum histórico e } \\
\text { fotográfico dos } \\
\text { postos } \\
\text { odontológicos do } \\
\text { serviço dentário } \\
\text { municipal de } \\
\text { Ribeirão Preto. }\end{array}$ & $\begin{array}{l}\text { A4 Fachada Parque Infantil } \\
\text { Amélia Junqueira }\end{array}$ & Fachada \\
\hline 9 & $\begin{array}{l}\text { Álbum histórico e } \\
\text { fotográfico dos } \\
\text { postos } \\
\text { odontológicos do } \\
\text { serviço dentário } \\
\text { municipal de } \\
\text { Ribeirão Preto. }\end{array}$ & $\begin{array}{l}\text { A4 Fachada Parque Infantil } \\
\text { Peixe Abbade }\end{array}$ & Fachada \\
\hline 10 & $\begin{array}{l}\text { Álbum histórico e } \\
\text { fotográfico dos } \\
\text { postos } \\
\text { odontológicos do } \\
\text { serviço dentário } \\
\text { municipal de } \\
\text { Ribeirão Preto. }\end{array}$ & A4 Atendimento odontológico & $\begin{array}{l}\text { Assistência médico- } \\
\text { odontológica }\end{array}$ \\
\hline 11 & $\begin{array}{l}\text { Álbum histórico e } \\
\text { fotográfico dos } \\
\text { postos } \\
\text { odontológicos do } \\
\text { serviço dentário } \\
\text { municipal de } \\
\text { Ribeirão Preto. }\end{array}$ & A4 Atendimento odontológico & $\begin{array}{l}\text { Assistência médico- } \\
\text { odontológica }\end{array}$ \\
\hline 12 & $\begin{array}{l}\text { Álbum histórico e } \\
\text { fotográfico dos } \\
\text { postos } \\
\text { odontológicos do } \\
\text { serviço dentário } \\
\text { municipal de } \\
\text { Ribeirão Preto. }\end{array}$ & A4 Atendimento odontológico & $\begin{array}{l}\text { Assistência médico- } \\
\text { odontológica }\end{array}$ \\
\hline
\end{tabular}




\begin{tabular}{|c|c|c|c|}
\hline 13 & $\begin{array}{l}\text { Álbum histórico e } \\
\text { fotográfico dos } \\
\text { postos } \\
\text { odontológicos do } \\
\text { serviço dentário } \\
\text { municipal de } \\
\text { Ribeirão Preto. }\end{array}$ & A4 Atendimento odontológico & $\begin{array}{l}\text { Assistência médico- } \\
\text { odontológica }\end{array}$ \\
\hline 14 & $\begin{array}{l}\text { Álbum histórico e } \\
\text { fotográfico dos } \\
\text { postos } \\
\text { odontológicos do } \\
\text { serviço dentário } \\
\text { municipal de } \\
\text { Ribeirão Preto. }\end{array}$ & A4 Atendimento odontológico & $\begin{array}{l}\text { Assistência médico- } \\
\text { odontológica }\end{array}$ \\
\hline 15 & $\begin{array}{l}\text { Álbum histórico e } \\
\text { fotográfico dos } \\
\text { postos } \\
\text { odontológicos do } \\
\text { serviço dentário } \\
\text { municipal de } \\
\text { Ribeirão Preto. }\end{array}$ & A4 Atendimento odontológico & $\begin{array}{l}\text { Assistência médico- } \\
\text { odontológica }\end{array}$ \\
\hline 16 & $\begin{array}{l}\text { Álbum histórico e } \\
\text { fotográfico dos } \\
\text { postos } \\
\text { odontológicos do } \\
\text { serviço dentário } \\
\text { municipal de } \\
\text { Ribeirão Preto. }\end{array}$ & A4 Atendimento odontológico & $\begin{array}{l}\text { Assistência médico- } \\
\text { odontológica }\end{array}$ \\
\hline 17 & $\begin{array}{l}\text { Álbum histórico e } \\
\text { fotográfico dos } \\
\text { postos } \\
\text { odontológicos do } \\
\text { serviço dentário } \\
\text { municipal de } \\
\text { Ribeirão Preto. }\end{array}$ & A4 Atendimento odontológico & $\begin{array}{l}\text { Assistência médico- } \\
\text { odontológica }\end{array}$ \\
\hline 18 & $\begin{array}{l}\text { Álbum histórico e } \\
\text { fotográfico dos } \\
\text { postos } \\
\text { odontológicos do } \\
\text { serviço dentário } \\
\text { municipal de } \\
\text { Ribeirão Preto. }\end{array}$ & A4 Atendimento odontológico & $\begin{array}{l}\text { Assistência médico- } \\
\text { odontológica }\end{array}$ \\
\hline
\end{tabular}




\begin{tabular}{|c|c|c|c|}
\hline 19 & $\begin{array}{l}\text { Álbum histórico e } \\
\text { fotográfico dos } \\
\text { postos } \\
\text { odontológicos do } \\
\text { serviço dentário } \\
\text { municipal de } \\
\text { Ribeirão Preto. }\end{array}$ & A4 Atendimento odontológico & $\begin{array}{l}\text { Assistência médico- } \\
\text { odontológica }\end{array}$ \\
\hline 20 & $\begin{array}{l}\text { Álbum histórico e } \\
\text { fotográfico dos } \\
\text { postos } \\
\text { odontológicos do } \\
\text { serviço dentário } \\
\text { municipal de } \\
\text { Ribeirão Preto. }\end{array}$ & A4 Atendimento odontológico & $\begin{array}{l}\text { Assistência médico- } \\
\text { odontológica }\end{array}$ \\
\hline 21 & $\begin{array}{l}\text { Álbum histórico e } \\
\text { fotográfico dos } \\
\text { postos } \\
\text { odontológicos do } \\
\text { serviço dentário } \\
\text { municipal de } \\
\text { Ribeirão Preto. }\end{array}$ & A4 Atendimento odontológico & $\begin{array}{l}\text { Assistência médico- } \\
\text { odontológica }\end{array}$ \\
\hline 22 & $\begin{array}{l}\text { Álbum histórico e } \\
\text { fotográfico dos } \\
\text { postos } \\
\text { odontológicos do } \\
\text { serviço dentário } \\
\text { municipal de } \\
\text { Ribeirão Preto. }\end{array}$ & A4 Atendimento odontológico & $\begin{array}{l}\text { Assistência médico- } \\
\text { odontológica }\end{array}$ \\
\hline 23 & $\begin{array}{l}\text { Álbum histórico e } \\
\text { fotográfico dos } \\
\text { postos } \\
\text { odontológicos do } \\
\text { serviço dentário } \\
\text { municipal de } \\
\text { Ribeirão Preto. }\end{array}$ & A4 Atendimento odontológico & $\begin{array}{l}\text { Assistência médico- } \\
\text { odontológica }\end{array}$ \\
\hline 24 & $\begin{array}{l}\text { Álbum histórico e } \\
\text { fotográfico dos } \\
\text { postos } \\
\text { odontológicos do } \\
\text { serviço dentário } \\
\text { municipal de } \\
\text { Ribeirão Preto. }\end{array}$ & A4 Atendimento odontológico & $\begin{array}{l}\text { Assistência médico- } \\
\text { odontológica }\end{array}$ \\
\hline
\end{tabular}




\begin{tabular}{|c|c|c|c|}
\hline 25 & $\begin{array}{l}\text { Álbum histórico e } \\
\text { fotográfico dos } \\
\text { postos } \\
\text { odontológicos do } \\
\text { serviço dentário } \\
\text { municipal de } \\
\text { Ribeirão Preto. }\end{array}$ & A4 Atendimento odontológico & $\begin{array}{l}\text { Assistência médico- } \\
\text { odontológica }\end{array}$ \\
\hline 26 & $\begin{array}{l}\text { Álbum histórico e } \\
\text { fotográfico dos } \\
\text { postos } \\
\text { odontológicos do } \\
\text { serviço dentário } \\
\text { municipal de } \\
\text { Ribeirão Preto. }\end{array}$ & A4 Atendimento odontológico & $\begin{array}{l}\text { Assistência médico- } \\
\text { odontológica }\end{array}$ \\
\hline 27 & $\begin{array}{l}\text { Álbum histórico e } \\
\text { fotográfico dos } \\
\text { postos } \\
\text { odontológicos do } \\
\text { serviço dentário } \\
\text { municipal de } \\
\text { Ribeirão Preto. }\end{array}$ & A4 Atendimento odontológico & $\begin{array}{l}\text { Assistência médico- } \\
\text { odontológica }\end{array}$ \\
\hline 28 & $\begin{array}{l}\text { Álbum histórico e } \\
\text { fotográfico dos } \\
\text { postos } \\
\text { odontológicos do } \\
\text { serviço dentário } \\
\text { municipal de } \\
\text { Ribeirão Preto. }\end{array}$ & A4 Atendimento odontológico & $\begin{array}{l}\text { Assistência médico- } \\
\text { odontológica }\end{array}$ \\
\hline 29 & $\begin{array}{l}\text { Álbum histórico e } \\
\text { fotográfico dos } \\
\text { postos } \\
\text { odontológicos do } \\
\text { serviço dentário } \\
\text { municipal de } \\
\text { Ribeirão Preto. }\end{array}$ & A4 Atendimento odontológico & $\begin{array}{l}\text { Assistência médico- } \\
\text { odontológica }\end{array}$ \\
\hline 30 & $\begin{array}{l}\text { Álbum histórico e } \\
\text { fotográfico dos } \\
\text { postos } \\
\text { odontológicos do } \\
\text { serviço dentário } \\
\text { municipal de } \\
\text { Ribeirão Preto. }\end{array}$ & A4 Atendimento odontológico & $\begin{array}{l}\text { Assistência médico- } \\
\text { odontológica }\end{array}$ \\
\hline
\end{tabular}




\begin{tabular}{|c|c|c|c|}
\hline 31 & $\begin{array}{l}\text { Álbum histórico e } \\
\text { fotográfico dos } \\
\text { postos } \\
\text { odontológicos do } \\
\text { serviço dentário } \\
\text { municipal de } \\
\text { Ribeirão Preto. }\end{array}$ & A4 Atendimento odontológico & $\begin{array}{l}\text { Assistência médico- } \\
\text { odontológica }\end{array}$ \\
\hline 32 & $\begin{array}{l}\text { Álbum histórico e } \\
\text { fotográfico dos } \\
\text { postos } \\
\text { odontológicos do } \\
\text { serviço dentário } \\
\text { municipal de } \\
\text { Ribeirão Preto. }\end{array}$ & A4 Atendimento odontológico & $\begin{array}{l}\text { Assistência médico- } \\
\text { odontológica }\end{array}$ \\
\hline 33 & $\begin{array}{l}\text { Álbum histórico e } \\
\text { fotográfico dos } \\
\text { postos } \\
\text { odontológicos do } \\
\text { serviço dentário } \\
\text { municipal de } \\
\text { Ribeirão Preto. }\end{array}$ & A4 Atendimento odontológico & $\begin{array}{l}\text { Assistência médico- } \\
\text { odontológica }\end{array}$ \\
\hline 34 & $\begin{array}{l}\text { Álbum histórico e } \\
\text { fotográfico dos } \\
\text { postos } \\
\text { odontológicos do } \\
\text { serviço dentário } \\
\text { municipal de } \\
\text { Ribeirão Preto. }\end{array}$ & A4 Atendimento odontológico & $\begin{array}{l}\text { Assistência médico- } \\
\text { odontológica }\end{array}$ \\
\hline 35 & $\begin{array}{l}\text { Álbum histórico e } \\
\text { fotográfico dos } \\
\text { postos } \\
\text { odontológicos do } \\
\text { serviço dentário } \\
\text { municipal de } \\
\text { Ribeirão Preto. }\end{array}$ & A4 Atendimento odontológico & $\begin{array}{l}\text { Assistência médico- } \\
\text { odontológica }\end{array}$ \\
\hline 36 & $\begin{array}{l}\text { Álbum histórico e } \\
\text { fotográfico dos } \\
\text { postos } \\
\text { odontológicos do } \\
\text { serviço dentário } \\
\text { municipal de } \\
\text { Ribeirão Preto. }\end{array}$ & A4 Atendimento odontológico & $\begin{array}{l}\text { Assistência médico- } \\
\text { odontológica }\end{array}$ \\
\hline
\end{tabular}




\begin{tabular}{|c|c|c|c|}
\hline 37 & $\begin{array}{l}\text { Álbum histórico e } \\
\text { fotográfico dos } \\
\text { postos } \\
\text { odontológicos do } \\
\text { serviço dentário } \\
\text { municipal de } \\
\text { Ribeirão Preto. }\end{array}$ & A4 Atendimento odontológico & $\begin{array}{l}\text { Assistência médico- } \\
\text { odontológica }\end{array}$ \\
\hline 38 & $\begin{array}{l}\text { Álbum histórico e } \\
\text { fotográfico dos } \\
\text { postos } \\
\text { odontológicos do } \\
\text { serviço dentário } \\
\text { municipal de } \\
\text { Ribeirão Preto. }\end{array}$ & A4 Atendimento odontológico & $\begin{array}{l}\text { Assistência médico- } \\
\text { odontológica }\end{array}$ \\
\hline 39 & $\begin{array}{l}\text { Álbum histórico e } \\
\text { fotográfico dos } \\
\text { postos } \\
\text { odontológicos do } \\
\text { serviço dentário } \\
\text { municipal de } \\
\text { Ribeirão Preto. }\end{array}$ & A4 Atendimento odontológico & $\begin{array}{l}\text { Assistência médico- } \\
\text { odontológica }\end{array}$ \\
\hline 40 & $\begin{array}{l}\text { Álbum histórico e } \\
\text { fotográfico dos } \\
\text { postos } \\
\text { odontológicos do } \\
\text { serviço dentário } \\
\text { municipal de } \\
\text { Ribeirão Preto. }\end{array}$ & A4 Atendimento odontológico & $\begin{array}{l}\text { Assistência médico- } \\
\text { odontológica }\end{array}$ \\
\hline 41 & $\begin{array}{l}\text { Álbum histórico e } \\
\text { fotográfico dos } \\
\text { postos } \\
\text { odontológicos do } \\
\text { serviço dentário } \\
\text { municipal de } \\
\text { Ribeirão Preto. }\end{array}$ & A4 Atendimento odontológico & $\begin{array}{l}\text { Assistência médico- } \\
\text { odontológica }\end{array}$ \\
\hline 42 & $\begin{array}{l}\text { Álbum histórico e } \\
\text { fotográfico dos } \\
\text { postos } \\
\text { odontológicos do } \\
\text { serviço dentário } \\
\text { municipal de } \\
\text { Ribeirão Preto. }\end{array}$ & A4 Atendimento odontológico & $\begin{array}{l}\text { Assistência médico- } \\
\text { odontológica }\end{array}$ \\
\hline
\end{tabular}




\begin{tabular}{|c|c|c|c|}
\hline 43 & Sem título (n. 5) & $\begin{array}{l}\text { A5 Lançamento da pedra } \\
\text { fundamental do Parque Infantil } \\
\text { Vila Tibério em 10/maio/1953 }\end{array}$ & $\begin{array}{l}\text { Lançamento da } \\
\text { pedra fundamental }\end{array}$ \\
\hline 44 & Sem título (n. 5) & $\begin{array}{l}\text { A5 Lançamento da pedra } \\
\text { fundamental do Parque Infantil } \\
\text { Vila Tibério em 10/maio/1953 }\end{array}$ & $\begin{array}{l}\text { Lançamento da } \\
\text { pedra fundamental }\end{array}$ \\
\hline 45 & Sem título (n. 5) & $\begin{array}{l}\text { A5 Lançamento da pedra } \\
\text { fundamental do Parque Infantil } \\
\text { Vila Tibério em 10/maio/1953 }\end{array}$ & $\begin{array}{l}\text { Lançamento da } \\
\text { pedra fundamental }\end{array}$ \\
\hline 46 & Sem título (n. 5) & $\begin{array}{l}\text { A5 Lançamento da pedra } \\
\text { fundamental do Parque Infantil } \\
\text { Vila Tibério em 10/maio/1953 }\end{array}$ & $\begin{array}{l}\text { Lançamento da } \\
\text { pedra fundamental }\end{array}$ \\
\hline 47 & Sem título (n. 5) & $\begin{array}{l}\text { A5 Lançamento da pedra } \\
\text { fundamental do Parque Infantil } \\
\text { Vila Tibério em 10/maio/1953 }\end{array}$ & $\begin{array}{l}\text { Lançamento da } \\
\text { pedra fundamental }\end{array}$ \\
\hline 48 & Sem título (n. 5) & $\begin{array}{l}\text { A5 Lançamento da pedra } \\
\text { fundamental do Parque Infantil } \\
\text { Vila Tibério em 10/maio/1953 }\end{array}$ & $\begin{array}{l}\text { Lançamento da } \\
\text { pedra fundamental }\end{array}$ \\
\hline 49 & Sem título (n. 5) & $\begin{array}{l}\text { A5 Lançamento da pedra } \\
\text { fundamental do Parque Infantil } \\
\text { Vila Tibério em 10/maio/1953 }\end{array}$ & $\begin{array}{l}\text { Lançamento da } \\
\text { pedra fundamental }\end{array}$ \\
\hline 50 & Sem título (n. 5) & $\begin{array}{l}\text { A5 Lançamento da pedra } \\
\text { fundamental do Parque Infantil } \\
\text { Vila Tibério em 10/maio/1953 }\end{array}$ & $\begin{array}{l}\text { Lançamento da } \\
\text { pedra fundamental }\end{array}$ \\
\hline 51 & Sem título (n. 5) & $\begin{array}{l}\text { A5 Lançamento da pedra } \\
\text { fundamental do Parque Infantil } \\
\text { Vila Tibério em 10/maio/1953 }\end{array}$ & $\begin{array}{l}\text { Lançamento da } \\
\text { pedra fundamental }\end{array}$ \\
\hline 52 & Sem título (n. 5) & $\begin{array}{l}\text { A5 Inauguração do Parque } \\
\text { Infantil Vila Tibério em } \\
\text { 8/dezembro/1964 }\end{array}$ & Inauguração \\
\hline 53 & Sem título (n. 5) & $\begin{array}{l}\text { A5 Inauguração do Parque } \\
\text { Infantil Vila Tibério em } \\
\text { 8/dezembro/1964 }\end{array}$ & Inauguração \\
\hline 54 & Sem título (n. 5) & $\begin{array}{l}\text { A5 Inauguração do Parque } \\
\text { Infantil Vila Tibério em } \\
\text { 8/dezembro/1964 }\end{array}$ & Inauguração \\
\hline 55 & Sem título (n. 5) & $\begin{array}{l}\text { A5 Inauguração do Parque } \\
\text { Infantil Vila Tibério em } \\
\text { 8/dezembro/1964 }\end{array}$ & Inauguração \\
\hline
\end{tabular}




\begin{tabular}{|c|c|c|c|}
\hline 56 & Sem título (n. 5) & $\begin{array}{l}\text { A5 Inauguração do Parque } \\
\text { Infantil Vila Tibério em } \\
\text { 8/dezembro/1964 }\end{array}$ & Inauguração \\
\hline 57 & Sem título (n. 5) & $\begin{array}{l}\text { A5 Inauguração da Piscina do } \\
\text { Parque Infantil Vila Tibério em } \\
\text { 8/dezembro/1964 }\end{array}$ & Inauguração \\
\hline 58 & Sem título (n. 5) & $\begin{array}{l}\text { A5 Inauguração do Gabinete } \\
\text { Dentário do Parque Infantil Vila } \\
\text { Tibério em 8/dezembro/1964 }\end{array}$ & Inauguração \\
\hline 59 & Sem título (n. 5) & $\begin{array}{l}\text { A5 Parque infantil Vila Virginia } \\
\text { cedido ao grupo escolar Meira } \\
\text { Junior }\end{array}$ & Arquitetura \\
\hline 60 & Sem título (n. 5) & $\begin{array}{l}\text { A5 Parque infantil Vila Virginia } \\
\text { cedido ao grupo escolar Meira } \\
\text { Junior }\end{array}$ & Arquitetura \\
\hline 61 & Sem título (n. 5) & $\begin{array}{l}\text { A5 Parque infantil Vila Virginia } \\
\text { cedido ao grupo escolar Meira } \\
\text { Junior }\end{array}$ & Solenidade \\
\hline 62 & Sem título (n. 5) & $\begin{array}{l}\text { A5 Parque infantil Vila Virginia } \\
\text { cedido ao grupo escolar Meira } \\
\text { Junior }\end{array}$ & Solenidade \\
\hline 63 & Sem título (n. 5) & $\begin{array}{l}\text { A5 Parque infantil Vila Virginia } \\
\text { cedido ao grupo escolar Meira } \\
\text { Junior }\end{array}$ & Solenidade \\
\hline 64 & Sem título (n. 5) & $\begin{array}{l}\text { A5 Parque infantil Vila Virginia } \\
\text { cedido ao grupo escolar Meira } \\
\text { Junior }\end{array}$ & Solenidade \\
\hline 65 & Sem título (n. 5) & $\begin{array}{l}\text { A5 Parque infantil Vila Virginia } \\
\text { cedido ao grupo escolar Meira } \\
\text { Junior }\end{array}$ & Solenidade \\
\hline 66 & Sem título (n. 5) & $\begin{array}{l}\text { A5 Parque infantil Vila Virginia } \\
\text { cedido ao grupo escolar Meira } \\
\text { Junior }\end{array}$ & Solenidade \\
\hline 67 & Sem título (n. 5) & $\begin{array}{l}\text { A5 Parque infantil Vila Virginia } \\
\text { cedido ao grupo escolar Meira } \\
\text { Junior }\end{array}$ & Solenidade \\
\hline 68 & Sem título (n. 5) & $\begin{array}{l}\text { A5 Parque infantil Vila Virginia } \\
\text { cedido ao grupo escolar Meira } \\
\text { Junior }\end{array}$ & Solenidade \\
\hline
\end{tabular}




\begin{tabular}{|c|c|c|c|}
\hline 69 & Sem título (n. 6) & $\begin{array}{l}\text { A6 Inauguração do Parque } \\
\text { Infantil Vila Bonfim }\end{array}$ & Inauguração \\
\hline 70 & Sem título (n. 6) & $\begin{array}{l}\text { A6 Inauguração do Parque } \\
\text { Infantil Vila Bonfim }\end{array}$ & Inauguração \\
\hline 71 & Sem título (n. 6) & $\begin{array}{l}\text { A6 Inauguração do Parque } \\
\text { Infantil Vila Bonfim }\end{array}$ & Inauguração \\
\hline 72 & Sem título (n. 6) & $\begin{array}{l}\text { A6 Inauguração do Parque } \\
\text { Infantil Vila Bonfim }\end{array}$ & Inauguração \\
\hline 73 & Sem título (n. 6) & $\begin{array}{l}\text { A6 Parque Infantil Praça } \\
\text { Antônio Prado, 10/maio/1953 }\end{array}$ & Olimpíada \\
\hline 74 & Sem título (n. 6) & $\begin{array}{l}\text { A6 Parque Infantil Praça } \\
\text { Antônio Prado, 10/maio/1953 }\end{array}$ & Pessoas \\
\hline 75 & Sem título (n. 6) & $\begin{array}{l}\text { A6 Parque Infantil Praça } \\
\text { Antônio Prado, 10/maio/1953 }\end{array}$ & Palestra \\
\hline 76 & Sem título (n. 7) & $\begin{array}{l}\text { A7 Inauguração Parque Infantil } \\
\text { Vila Tibério }\end{array}$ & Inauguração \\
\hline 77 & Sem título (n. 7) & $\begin{array}{l}\text { A7 Inauguração Parque Infantil } \\
\text { Vila Tibério }\end{array}$ & Inauguração \\
\hline 78 & Sem título (n. 7) & $\begin{array}{l}\text { A7 Inauguração Parque Infantil } \\
\text { Vila Tibério }\end{array}$ & Fachada \\
\hline 79 & Sem título (n. 7) & A7 Sem legenda & $\begin{array}{l}\text { Criança posada } \\
\text { (grupo) }\end{array}$ \\
\hline 80 & Sem título (n. 7) & A7 Sem legenda & $\begin{array}{l}\text { Assistência } \\
\text { alimentar }\end{array}$ \\
\hline 81 & Sem título (n. 7) & A7 Sem legenda & Olimpíada \\
\hline 82 & Sem título (n. 7) & A7 Sem legenda & Grupo posado \\
\hline 83 & Sem título (n. 7) & A7 Sem legenda & Pessoas \\
\hline 84 & Sem título (n. 7) & A7 Sem legenda & Pessoas \\
\hline 85 & Sem título (n. 7) & A7 Sem legenda & Pessoas \\
\hline 86 & Sem título (n. 7) & A7 Sem legenda & Pessoas \\
\hline 87 & Sem título (n. 7) & A7 Sem legenda & Pessoas \\
\hline 88 & Sem título (n. 7) & A7 Sem legenda & Construção \\
\hline 89 & Sem título (n. 7) & A7 Sem legenda & Construção \\
\hline 90 & Sem título (n. 7) & A7 Sem legenda & Arquitetura \\
\hline
\end{tabular}




\begin{tabular}{|l|l|l|l|}
\hline 91 & Sem título (n. 7) & A7 Sem legenda & Arquitetura \\
\hline $\mathbf{9 2}$ & Sem título (n. 7) & A7 Sem legenda & $\begin{array}{l}\text { Criança posada } \\
\text { (grupo) }\end{array}$ \\
\hline
\end{tabular}


APÊNDICE E - Quadro com as temáticas das fotografias avulsas sobre os parques infantis depositados no Arquivo Público e Histórico de Ribeirão Preto ${ }^{127}$

\begin{tabular}{|c|c|c|c|}
\hline & Fotografias avulsas & Temática & Fotógrafo/Estúdio \\
\hline 1 & $\begin{array}{l}\text { Escola Municipal Maria Goretti (Parque } \\
\text { Infantil) no Bairro Ipiranga. Vista de uma sala } \\
\text { de aula com meninos uniformizados } \\
\text { acenando. Na direita, em pé, professoras, entre } \\
\text { elas, Estela Bueno Araújo e Alfeu Luiz } \\
\text { Gasparini. No fundo, junto a porta, um grupo } \\
\text { de professoras. }\end{array}$ & $\begin{array}{l}\text { Grupo de } \\
\text { crianças }\end{array}$ & Foto Kamada \\
\hline 2 & $\begin{array}{l}\text { Grupo de crianças, provavelmente alunos do } \\
\text { parque infantil. }\end{array}$ & $\begin{array}{l}\text { Criança posada } \\
\text { (grupo) }\end{array}$ & $\begin{array}{l}\text { Casa Costa - } \\
\text { Revelações, } \\
\text { Copias e } \\
\text { Ampliações. }\end{array}$ \\
\hline 3 & $\begin{array}{l}\text { Grupo de alunos do Parque Infantil do Bosque } \\
\text { durante aula de ginástica. Na frente do grupo, } \\
\text { a professora. }\end{array}$ & Educação física & Foto Miyasaka \\
\hline 4 & $\begin{array}{l}\text { Grupo de professoras do Parque Infantil de } \\
\text { Vila Virgínia. }\end{array}$ & Professoras & Foto Miyasaka \\
\hline 5 & $\begin{array}{l}\text { Salão de refeições do Parque Infantil de } \\
\text { Dumont. Crianças sentadas à mesa, algumas } \\
\text { estão comendo. }\end{array}$ & $\begin{array}{l}\text { Assistência } \\
\text { alimentar }\end{array}$ & Foto Miyasaka \\
\hline 6 & $\begin{array}{l}\text { Aula de música. Grupo de alunos e } \\
\text { professoras do Parque Infantil do Barracão. } \\
\text { Crianças seguram instrumentos musicais: } \\
\text { triangulo, pandeiro, tambor e chocalho. }\end{array}$ & Aula de música & Foto Miyasaka \\
\hline 7 & $\begin{array}{l}\text { Grupo de alunos e professoras do Parque } \\
\text { Infantil de Vila Tibério. Vista dos jardins e do } \\
\text { prédio. }\end{array}$ & $\begin{array}{l}\text { Criança posada } \\
\text { (grupo) }\end{array}$ & Foto Miyasaka \\
\hline 8 & $\begin{array}{l}\text { Alunas do Parque Infantil de Bonfim Paulista, } \\
\text { oferecendo ao Cel. Alfredo Condeixa Filho, } \\
\text { um ramalhete de flores, em sinal de } \\
\text { agradecimento aos melhoramentos recebidos } \\
\text { (inscrição no verso da foto). }\end{array}$ & $\begin{array}{l}\text { Criança posada } \\
\text { (grupo) }\end{array}$ & Foto Miyasaka \\
\hline
\end{tabular}

${ }^{127}$ Quadro elaborado de acordo com o inventário das fotografias avulsas do Arquivo Público e Histórico de Ribeirão Preto. 


\begin{tabular}{|c|c|c|c|}
\hline 9 & $\begin{array}{l}\text { Inauguração do Parque Infantil de Bonfim } \\
\text { Paulista. Descerramento da fita com a } \\
\text { presença de Ademar de Barros. }\end{array}$ & Inauguração & Não identificado \\
\hline 10 & $\begin{array}{l}\text { Parque Infantil de Dumont. Fila de criança } \\
\text { segundo canecas recebem leito ou vitamina. } \\
\text { Sobre a mesa um liquidificador, bananas, e } \\
\text { um coco. }\end{array}$ & $\begin{array}{l}\text { Assistência } \\
\text { alimentar }\end{array}$ & Foto Miyasaka \\
\hline 11 & $\begin{array}{l}\text { Parque Infantil do Barracão. Grupo de alunos, } \\
\text { professoras e funcionários distribuídos nas } \\
\text { escadarias na frente do prédio. }\end{array}$ & $\begin{array}{l}\text { Criança posada } \\
\text { (grupo) }\end{array}$ & Foto Miyasaka \\
\hline 12 & $\begin{array}{l}\text { Parque Infantil do Barracão. Crianças sentadas } \\
\text { junto a mesas, em grupos de quatro, recebem } \\
\text { prato de sopa. Senhoras e jovens estão } \\
\text { servindo as crianças. }\end{array}$ & $\begin{array}{l}\text { Assistência } \\
\text { alimentar }\end{array}$ & Foto Miyasaka \\
\hline 13 & $\begin{array}{l}\text { Parque Infantil do Barracão. Crianças junto a } \\
\text { uma mesa de pingue-pongue acompanham } \\
\text { quatro crianças jogando. Ao lado da mesa está } \\
\text { um homem trajando shorts, possivelmente, } \\
\text { professor; trata-se um negro ou } \\
\text { afrodescendente. }\end{array}$ & Jogos & Foto Miyasaka \\
\hline 14 & $\begin{array}{l}\text { Parque Infantil do Barracão. Criança sentada } \\
\text { num banco tem os seus cabelos cortados por } \\
\text { um barbeiro. Na parede do fundo, há um } \\
\text { desenho dos personagens a Dama e o } \\
\text { Vagabundo do Walt Disney. }\end{array}$ & Barbeiro & Foto Miyasaka \\
\hline 15 & $\begin{array}{l}\text { Parque Infantil do Barracão. Crianças junto a } \\
\text { quadra esportiva jogam bola ao cesto ou } \\
\text { basquete. A atividade é acompanhada por um } \\
\text { homem trajando shorts, possivelmente, } \\
\text { professor; trata-se um negro ou } \\
\text { afrodescendente. }\end{array}$ & Educação física & Foto Miyasaka \\
\hline 16 & $\begin{array}{l}\text { Parque Infantil do Barracão. Crianças sentadas } \\
\text { junto a mesas, em grupos de quatro, lendo } \\
\text { livros. Na parede do fundo há um desenho do } \\
\text { Mickey, personagem do Walt Disney. Sobre } \\
\text { uma mesa há uma imagem de santo, } \\
\text { possivelmente, Nossa Senhora. }\end{array}$ & Leitura & Foto Miyasaka \\
\hline 17 & $\begin{array}{l}\text { Crianças durante aula de Educação Física no } \\
\text { Parque Infantil do Barracão, atual bairro do } \\
\text { Ipiranga. Um grupo de crianças está em fila; }\end{array}$ & Educação física & Foto Miyasaka \\
\hline
\end{tabular}




\begin{tabular}{|c|c|c|c|}
\hline & $\begin{array}{l}\text { outas criança estão deitadas numa formação } \\
\text { de círculo. }\end{array}$ & & \\
\hline 18 & $\begin{array}{l}\text { Parque Infantil do Barracão. Crianças junto a } \\
\text { quadra esportiva jogam volei. }\end{array}$ & Educação física & Foto Miyasaka \\
\hline 19 & $\begin{array}{l}\text { Parque Infantil do Barracão. Crianças } \\
\text { brincando no gira-gira; acompanhadas por } \\
\text { professoras. }\end{array}$ & $\begin{array}{l}\text { Brincadeiras em } \\
\text { aparelhos }\end{array}$ & Foto Miyasaka \\
\hline 20 & $\begin{array}{l}\text { Parque Infantil do Barracão. Crianças jogando } \\
\text { bola num gramado, próximas a um numa barra } \\
\text { de ginástica; acompanhadas por um professor. }\end{array}$ & Educação física & Foto Miyasaka \\
\hline 21 & $\begin{array}{l}\text { Parque Infantil do Barracão. Cozinheiras } \\
\text { preparam alimentos em duas grandes panelas, } \\
\text { num fogão de lenha. }\end{array}$ & $\begin{array}{l}\text { Assistência } \\
\text { alimentar }\end{array}$ & Foto Miyasaka \\
\hline 22 & $\begin{array}{l}\text { Parque Infantil do Barracão. Atividade num } \\
\text { auditório. Palestra dirigida a mães de alunos, } \\
\text { algumas estão junto a crianças de colo. No } \\
\text { fundo, à direita, barbeiro corte cabelo de um } \\
\text { menino. }\end{array}$ & Palestra & Foto Miyasaka \\
\hline 23 & $\begin{array}{l}\text { Parque Infantil do Barracão. Banho. Três } \\
\text { garotos estão embaixo de chuveiros, tomando } \\
\text { banho. }\end{array}$ & Banho & Foto Miyasaka \\
\hline 24 & $\begin{array}{l}\text { Parque Infantil do Barracão. Vista da piscina e } \\
\text { jardins. Crianças realizando atividade com } \\
\text { bola na piscina. }\end{array}$ & Piscina & Foto Miyasaka \\
\hline 25 & $\begin{array}{l}\text { Parque Infantil do Barracão. Ambulatório } \\
\text { médico. Criança sobre uma mesa recebe } \\
\text { tratamento realizado por uma mulher. }\end{array}$ & $\begin{array}{l}\text { Assistência } \\
\text { médico- } \\
\text { odontológica }\end{array}$ & Foto Miyasaka \\
\hline 26 & $\begin{array}{l}\text { Parque Infantil do Barracão. Ambulatório } \\
\text { médico. Criança sobre uma mesa recebe } \\
\text { tratamento realizado por uma mulher. }\end{array}$ & $\begin{array}{l}\text { Assistência } \\
\text { médico- } \\
\text { odontológica }\end{array}$ & Foto Miyasaka \\
\hline 27 & $\begin{array}{l}\text { Parque Infantil do Barracão. Consultório do } \\
\text { dentista. Criança recebe tratamento dentário } \\
\text { realizado por um homem. }\end{array}$ & $\begin{array}{l}\text { Assistência } \\
\text { médico- } \\
\text { odontológica }\end{array}$ & Foto Miyasaka \\
\hline 28 & $\begin{array}{l}\text { Parque Infantil do Barracão. Consultório do } \\
\text { dentista. Criança recebe tratamento dentário } \\
\text { realizado por um homem; uma mulher observa } \\
\text { a cena. }\end{array}$ & $\begin{array}{l}\text { Assistência } \\
\text { médico- } \\
\text { odontológica }\end{array}$ & Foto Miyasaka \\
\hline
\end{tabular}




\begin{tabular}{|c|c|c|c|}
\hline 29 & $\begin{array}{l}\text { Parque Infantil Amélia Junqueira, no Bosque. } \\
\text { Vista da fachada e lateral do prédio; um } \\
\text { gramado e grupo de crianças }\end{array}$ & Arquitetura & Foto Miyasaka \\
\hline 30 & $\begin{array}{l}\text { Parque Infantil Amélia Junqueira, no Bosque. } \\
\text { Vista da fachada do prédio com a presença } \\
\text { dos alunos e professoras, em formação no } \\
\text { gramado em frente ao prédio. }\end{array}$ & $\begin{array}{l}\text { Criança posada } \\
\text { (grupo) }\end{array}$ & Foto Miyasaka \\
\hline 31 & $\begin{array}{l}\text { Parque Infantil Amélia Junqueira, no Bosque. } \\
\text { Grupo de professoras e funcionários nas } \\
\text { escadas de frente ao prédio. }\end{array}$ & Professoras & Foto Miyasaka \\
\hline 32 & $\begin{array}{l}\text { Parque Infantil Amélia Junqueira, no Bosque. } \\
\text { Grupos de crianças sentadas em mesas com } 12 \\
\text { ou } 14 \text { lugares tomam uma refeição. Junto a } \\
\text { uma mesa, em pé, uma professora. }\end{array}$ & $\begin{array}{l}\text { Assistência } \\
\text { alimentar }\end{array}$ & Foto Miyasaka \\
\hline 33 & $\begin{array}{l}\text { Parque Infantil Amélia Junqueira, no Bosque. } \\
\text { Vista da piscina, jardim e prédio. Crianças em } \\
\text { atividades na piscina. }\end{array}$ & Piscina & Foto Miyasaka \\
\hline 34 & $\begin{array}{l}\text { Parque Infantil Amélia Junqueira, no Bosque. } \\
\text { Vista do ambulatório médico. Criança deitada } \\
\text { numa maca recebe tratamento realizado por } \\
\text { uma mulher. }\end{array}$ & $\begin{array}{l}\text { Assistência } \\
\text { médico- } \\
\text { odontológica }\end{array}$ & Foto Miyasaka \\
\hline 35 & $\begin{array}{l}\text { Parque Infantil Amélia Junqueira, no Bosque. } \\
\text { Vista do consultório dentário. Criança sentada } \\
\text { na cadeira de dentista recebe tratamento } \\
\text { dentário realizado por uma mulher. }\end{array}$ & $\begin{array}{l}\text { Assistência } \\
\text { médico- } \\
\text { odontológica }\end{array}$ & Foto Miyasaka \\
\hline 36 & $\begin{array}{l}\text { Parque Infantil de Vila Tibério, vista do } \\
\text { prédio, jardins, gramado e grupo de crianças; } \\
\text { tomada a partir de um ponto no alto. No } \\
\text { fundo, vista da silhueta das arquibancadas e } \\
\text { torres de iluminação do estádio Luiz Pereira, } \\
\text { do Botafogo Futebol Clube. }\end{array}$ & Arquitetura & Foto Miyasaka \\
\hline 37 & $\begin{array}{l}\text { Parque Infantil de Vila Tibério. Vista de grupo } \\
\text { de crianças e professoras, em formação, num } \\
\text { gramado. }\end{array}$ & $\begin{array}{l}\text { Criança posada } \\
\text { (grupo) }\end{array}$ & Foto Miyasaka \\
\hline 38 & $\begin{array}{l}\text { Parque Infantil de Vila Tibério. Ambulatório } \\
\text { médico. Criança sentada sobre uma bancada } \\
\text { recebe tratamento realizado por uma mulher. } \\
\text { A criança está chorando. A cena é } \\
\text { acompanhada por outras três crianças. }\end{array}$ & $\begin{array}{l}\text { Assistência } \\
\text { médico- } \\
\text { odontológica }\end{array}$ & Foto Miyasaka \\
\hline
\end{tabular}




\begin{tabular}{|c|c|c|c|}
\hline 39 & $\begin{array}{l}\text { Parque Infantil de Vila Tibério. Vista da } \\
\text { piscina e do prédio. Crianças realizando } \\
\text { atividades na piscina. Dois garotos, crianças, } \\
\text { assistem a cena junto a uma cerca de madeira. }\end{array}$ & Piscina & Foto Miyasaka \\
\hline 40 & $\begin{array}{l}\text { Parque Infantil de Bonfim Paulista. Vista da } \\
\text { cozinha e fogão de lenha. Uma senhora está } \\
\text { preparando alimentos em duas grandes } \\
\text { panelas e caldeirão. Sobre a mesa um vaso } \\
\text { com folhagem. }\end{array}$ & $\begin{array}{l}\text { Assistência } \\
\text { alimentar }\end{array}$ & Foto Miyasaka \\
\hline 41 & $\begin{array}{l}\text { Parque Infantil de Bonfim Paulista. Vista de } \\
\text { um galpão onde crianças tomam refeição junto } \\
\text { a mesas de quatro lugares. }\end{array}$ & $\begin{array}{l}\text { Assistência } \\
\text { alimentar }\end{array}$ & Foto Miyasaka \\
\hline 42 & $\begin{array}{l}\text { Parque Infantil de Bonfim Paulista. Vista de } \\
\text { um gramado com balanços e gangorras. } \\
\text { Crianças estão em atividades nos brinquedos e } \\
\text { brincando de roda. }\end{array}$ & $\begin{array}{l}\text { Brincadeiras em } \\
\text { aparelhos }\end{array}$ & Foto Miyasaka \\
\hline 43 & $\begin{array}{l}\text { Parque Infantil de Dumont. Vista de um } \\
\text { gramado, prédio e armação para jogo de bola } \\
\text { ao cesto ou basquete. Crianças estão em } \\
\text { atividades no gramado, brincando de roda e } \\
\text { com bola. }\end{array}$ & Brincadeiras & Foto Miyasaka \\
\hline 44 & $\begin{array}{l}\text { Parque Infantil de Dumont. Vista de um } \\
\text { escorregador, de um gramado e do prédio. } \\
\text { Crianças estão em atividades no gramado. }\end{array}$ & Brincadeiras & Foto Miyasaka \\
\hline 45 & $\begin{array}{l}\text { Parque Infantil de Dumont. Vista do } \\
\text { ambulatório médico. Um garoto sentado sobre } \\
\text { uma bancada recebe tratamento realizado por } \\
\text { um homem. }\end{array}$ & $\begin{array}{l}\text { Assistência } \\
\text { médico- } \\
\text { odontológica }\end{array}$ & Foto Miyasaka \\
\hline 46 & $\begin{array}{l}\text { Parque Infantil de Vila Virginia. Vista do } \\
\text { prédio e gramado. }\end{array}$ & Arquitetura & Foto Miyasaka \\
\hline 47 & $\begin{array}{l}\text { Parque Infantil de Vila Virginia. Vista do } \\
\text { consultório dentário. Criança sentada na } \\
\text { cadeira de dentista recebe tratamento } \\
\text { realizado por uma mulher. }\end{array}$ & $\begin{array}{l}\text { Assistência } \\
\text { médico- } \\
\text { odontológica }\end{array}$ & Foto Miyasaka \\
\hline 48 & $\begin{array}{l}\text { Parque Infantil de Vila Virginia. Vista do } \\
\text { escorregador. Crianças em atividades. }\end{array}$ & Brincadeiras & Foto Miyasaka \\
\hline 49 & $\begin{array}{l}\text { Parque Infantil de Vila Virginia. Vista de } \\
\text { grupos de alunos, professoras e funcionárias } \\
\text { em formação em frente ao prédio. }\end{array}$ & $\begin{array}{l}\text { Criança posada } \\
\text { (grupo) }\end{array}$ & Foto Miyasaka \\
\hline
\end{tabular}




\begin{tabular}{|c|c|c|c|}
\hline 50 & $\begin{array}{l}\text { Parque Infantil dos Bandeirantes. Vista da } \\
\text { fachada do prédio, muro e portão de entrada. }\end{array}$ & Arquitetura & Foto Miyasaka \\
\hline 51 & $\begin{array}{l}\text { Parque Infantil dos Bandeirantes. Dom } \\
\text { Agnelo Rossi descerrando a fita de } \\
\text { inauguração. Ao seu lado estão o Cel. Alfredo } \\
\text { Condeixa Filho, entre outros. Um repórter } \\
\text { segura um microfone nas mãos. }\end{array}$ & Inauguração & Foto Miyasaka \\
\hline 52 & $\begin{array}{l}\text { Parque Infantil dos Bandeirantes. Vista da } \\
\text { fachada durante solenidade de inauguração. } \\
\text { Com a presença Dom Agnelo Rossi, Cel. } \\
\text { Alfredo Condeixa Filho, entre outros. }\end{array}$ & Inauguração & Foto Miyasaka \\
\hline 53 & $\begin{array}{l}\text { Parque Infantil dos Bandeirantes. Vista da } \\
\text { fachada do prédio e grande número de pessoas } \\
\text { durante solenidade de inauguração. }\end{array}$ & Inauguração & Foto Miyasaka \\
\hline 54 & $\begin{array}{l}\text { Parque Infantil dos Bandeirantes. Vista de } \\
\text { uma apresentação de dança com crianças, num } \\
\text { galpão com grande número de pessoas, } \\
\text { durante solenidade de inauguração. }\end{array}$ & Inauguração & Foto Miyasaka \\
\hline 55 & $\begin{array}{l}\text { Parque Infantil dos Bandeirantes. Vista de } \\
\text { uma apresentação de crianças, sobre palco, } \\
\text { num galpão com grande número de pessoas, } \\
\text { durante solenidade de inauguração. }\end{array}$ & Inauguração & Foto Miyasaka \\
\hline 56 & $\begin{array}{l}\text { Parque Infantil dos Bandeirantes. Vista do } \\
\text { prédio e grande número de crianças durante } \\
\text { solenidade de inauguração. }\end{array}$ & Inauguração & Foto Miyasaka \\
\hline 57 & $\begin{array}{l}\text { Parque Infantil dos Bandeirantes. Vista do } \\
\text { prédio e grande número de crianças durante } \\
\text { solenidade de inauguração. Crianças sobre o } \\
\text { escorregador na no gira-gira. }\end{array}$ & Inauguração & Foto Miyasaka \\
\hline 58 & $\begin{array}{l}\text { Parque Infantil dos Bandeirantes. Vista do } \\
\text { prédio e grande número de crianças durante } \\
\text { solenidade de inauguração. Crianças e garotos } \\
\text { sobre o escorregador. }\end{array}$ & Inauguração & Foto Miyasaka \\
\hline 59 & $\begin{array}{l}\text { Parque Infantil dos Bandeirantes. Vista do } \\
\text { prédio de dois grandes escorregadores. } \\
\text { Presença de um grande número de pessoas. }\end{array}$ & Inauguração & Foto Miyasaka \\
\hline 60 & $\begin{array}{l}\text { Inauguração do Parque Infantil dos } \\
\text { Bandeirantes. Vista do prédio, grupos de } \\
\text { pessoas guarda sol e escorregador. }\end{array}$ & Inauguração & Foto Miyasaka \\
\hline
\end{tabular}




\begin{tabular}{|c|c|c|c|}
\hline 61 & $\begin{array}{l}\text { Inauguração do Parque Infantil dos } \\
\text { Bandeirantes. Descerramento da fita de } \\
\text { inauguração do gabinete médico. Presença de } \\
\text { Cel. Alfredo Condeixa Filho. }\end{array}$ & Inauguração & Foto Miyasaka \\
\hline 62 & $\begin{array}{l}\text { Inauguração do Parque Infantil dos } \\
\text { Bandeirantes. Descerramento da fita de } \\
\text { inauguração do gabinete dentário. Presença de } \\
\text { Cel. Alfredo Condeixa Filho. }\end{array}$ & Inauguração & Foto Miyasaka \\
\hline 63 & $\begin{array}{l}\text { Inauguração do Parque Infantil dos } \\
\text { Bandeirantes. Descerramento de fita inaugural } \\
\text { de sala no interior do prédio. }\end{array}$ & Inauguração & Foto Miyasaka \\
\hline 64 & $\begin{array}{l}\text { Parque Infantil dos Bandeirantes. Solenidade } \\
\text { de inauguração. Momento em que o prefeito, } \\
\text { Cel. Alfredo Condeixa Filho, abre o portão de } \\
\text { entrada. }\end{array}$ & Inauguração & Foto Miyasaka \\
\hline 65 & $\begin{array}{l}\text { Solenidade no interior de um galpão, } \\
\text { possivelmente, num Parque Infantil. Momento } \\
\text { em que uma senhora recebe um ramalhete de } \\
\text { folhagens entregue por uma criança afro } \\
\text { descendente. Grande número de pessoas, entre } \\
\text { elas: Monsenhor João Lauriano, entre outras. }\end{array}$ & Inauguração & Foto Miyasaka \\
\hline 66 & $\begin{array}{l}\text { Parque Infantil do Bosque Municipal - prédio } \\
\text { e piscina. }\end{array}$ & Arquitetura & $\begin{array}{l}\text { Foto Esporte / } \\
\text { Livraria Católica } \\
\text { Ltda. }\end{array}$ \\
\hline
\end{tabular}




\title{
ANEXOS
}

ANEXO A - Primeira página do termo de responsabilidade para acesso e uso de imagem para fins científicos, acadêmicos e culturais

\author{
ARQUIVO PÚBLICO E HISTÓRICO DE RIBEIRÃO PRETO \\ (Lei Complementar n. 130/1992)
TERRSO RESPONSABILIDADE PARA
ACESSO I USO DE IMAGEM PARA FINS CIBNTIFICOS, ACADEMICOS E CULTURATS.

Normas de acesso e utilizaçẩo

1- 0 acervo de imagens do Arquivo público e Historico de Ribeirāo Preto está disponivel para consulta publica excetuando os documentos em regime de restricão ou interdiço por razōes de conservaço ou organizacional.

2- E permitida a reproducāo das imagens integrantes do acervo do Arquivo Poblico e Historico de Ribeiräo Preto mediante observaçto e eumprinento da legislağo: Lel de Direitos hutorais (Lei Federal n. 9.610, de 19 de feverelro de 1998); Le1 sobre a Polltica Nacional de Arquivos Públicos e Privados (Lei Federal n.8.159, de os de janeiro de 1991); Lel que dispoe sobre o Arquivo Público e Historico de Ribeirão Preto (Lel Complementar Municipal n.130, de 02 de Julho de 1992) e Lei que considera de valor histórico e cultural o acervo do Arquivo Público e Historico de Ribeiräo Preto (Lei Municipal n. 8.445, de 20 de maio de 1999).

3- A consulta a acervo de imagens conforme estabelecido no item n. 1 deste Termo, 6 permitida somente nas dependênclas da sede do Arquivo Público e Histórico de Ribeirăo Preto; o nesmo se aplica aos procedimentos de reproduçaso das imagens.

4- As inagens liberadas para reproduç̃o, em conformidade com os enunciados nos itens ns. 2 e 3 deste Termo, deven ser utilizadas exclusivanente para fins cientificos, acadêmicos e culturais.

5- A permissa para a reproducio de inagens para tins cientificos, academicos e culturais será concedida mediante a plena aceitęão das normas estabelecidas neste Termo.

\section{Termo de Responsabilidade}

1- Comprometo-me a dar aos trabalhos elaborados com base no acervo de imagens do Arquivo poblico e Historico de Ribeiräo Preto os respectivos ereditos a Instituicaio, ao conjunto documental consultado e aos respectivos autores/fotógrafos.

2- Comproneto-me a utilizar os documentos solicitados exclusivamente paŕa a finalidade declarada e nāo cedé-los a terceiros.

3- Declaro estar ciente que a utilizaça indevida dos documentos estará sujeita às penalidades previstas na legislaço en vigor.

4- Comprometo-me a enviar a Arquivo Publico e Historico de Ribelrăo Preto, copia ou exemplar dos trabalhos realizados con base no acervo de imagens, para o endereco:

Arquivo Pablico e Histórico de Ribelrdio Preto

Rua Jose da silva; 915

CBP. 14090-042 /Ribeiräo Preto - SP / Brasil

E-mail: arquivolcultura.pmrp.com.br 
ANEXO B - Segunda página do termo de responsabilidade para acesso e uso de imagem para fins científicos, acadêmicos e culturais

\section{ARQUTVO PÚBLICO E HISTÓRICO DE RIBEIRÃO PRETO \\ (Lei Complementar n. 130/1992)}

Dados Pessoais/Institucionais:

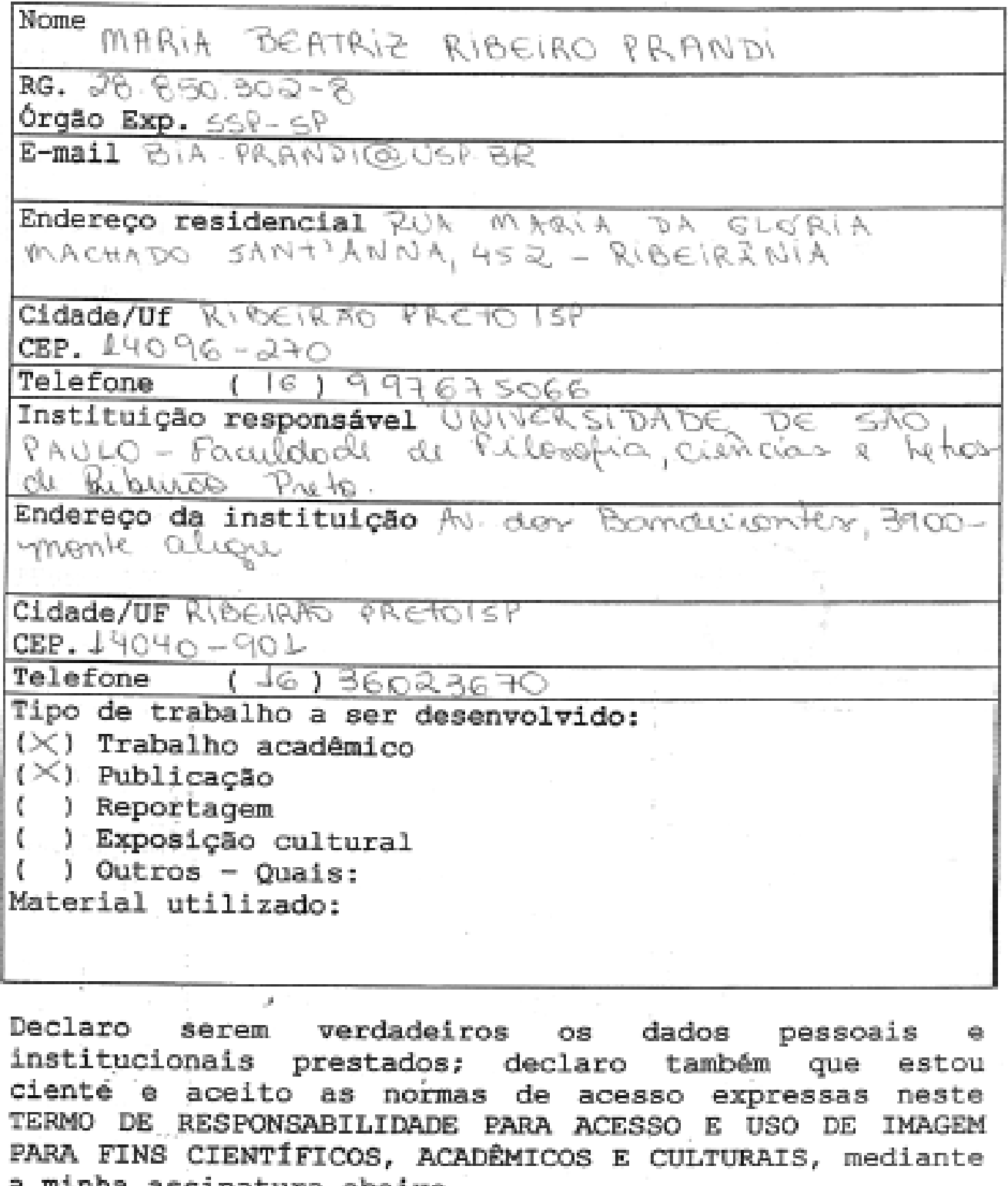
a minha assinatura abaixo.

Assinaturatoforowol

Data: 011 out 12014

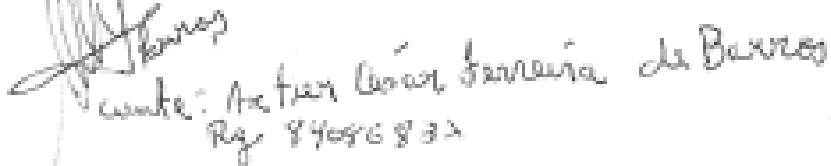

TERMO DE RESPCINSABILIDADE PARA ACESSO E USO DE RMAGEM PARA FINS CENTIFICOS, ? ACADEMAOOS E CULTURAIS. 